UNIVERSIDADE DE BRASÍLIA

FACULDADE DE TECNOLOGIA

DEPARTAMENTO DE ENGENHARIA CIVIL E AMBIENTAL

LODOS GERADOS NAS ESTAÇÕES DE TRATAMENTO DE ESGOTOS NO DISTRITO FEDERAL: UM ESTUDO DE SUA APTIDÃO PARA O CONDICIONAMENTO, UTILIZAÇÃO E DISPOSIÇÃO FINAL

LUCILENE FERREIRA BATISTA

ORIENTADOR: MARCO ANTONIO ALMEIDA DE SOUZA

DISSERTAÇÃO DE MESTRADO EM TECNOLOGIA AMBIENTAL E RECURSOS HÍDRICOS

PUBLICAÇÃO: PTARH.DM - 168/2015

BRASÍLIA/DF: MARÇO - 2015 
UNIVERSIDADE DE BRASÍLIA

FACULDADE DE TECNOLOGIA

DEPARTAMENTO DE ENGENHARIA CIVIL E AMBIENTAL

\section{LODOS GERADOS NAS ESTAÇÕES DE TRATAMENTO DE ESGOTOS NO DISTRITO FEDERAL: UM ESTUDO DE SUA APTIDÃO PARA O CONDICIONAMENTO, UTILIZAÇÃO E DISPOSIÇÃO FINAL}

\section{LUCILENE FERREIRA BATISTA}

DISSERTAÇÃO SUBMETIDA AO DEPARTAMENTO DE ENGENHARIA CIVIL E AMBIENTAL DA FACULDADE DE TECNOLOGIA DA UNIVERSIDADE DE BRASÍlIA COMO PARTE DOS REQUISISTOS NECESSÁRIOS PARA A OBTENÇÃO DO GRAU DE MESTRE EM TECNOLOGIA AMBIENTAL E RECURSOS HÍDRICOS.

APROVADA POR:

Prof. Marco Antonio Almeida de Souza, PhD (ENC-UnB)

(Orientador)

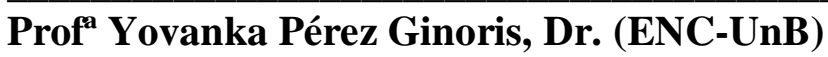

(Examinador Interno)

Prof. Valderi Duarte Leite, Dr. (UEPB)

(Examinador Externo)

BRASÍLIA-DF, 23 DE MARÇO DE 2015. 
FICHA CATALOGRÁFICA

BATISTA, L.F.

LODOS GERADOS NAS ESTAÇÕES DE TRATAMENTO DE ESGOTOS NO DISTRITO FEDERAL: UM ESTUDO DE SUA APTIDÃO PARA O CONDICIONAMENTO, UTILIZAÇÃO E DISPOSIÇÃO FINAL. xxvii, 197p., 210 x 297 mm (ENC/FT/UnB, Mestre, Tecnologia Ambiental e Recursos Hídricos, 2015). Dissertação de Mestrado - Universidade de Brasília. Faculdade de Tecnologia. Departamento de Engenharia Civil e Ambiental.
1. LODO DE ESGOTOS
2. TRATAMENTO DE LODOS
3. DISPOSIÇÃO FINAL
I. ENC/FT/UnB
II. Título (série)

\section{REFERÊNCIA BIBLIOGRÁFICA}

BATISTA, L.F. (2015). Lodos gerados nas estações de tratamento de esgotos no Distrito Federal: um estudo de sua aptidão para o condicionamento, utilização e disposição final. Dissertação de Mestrado em Tecnologia Ambiental e Recursos Hídricos, Publicação PTARH.DM-168/2015, Departamento de Engenharia Civil e Ambiental, Universidade de Brasília, Brasília, DF, 197p.

\section{CESSÃO DE DIREITOS}

NOME DA AUTORA: Lucilene Ferreira Batista

TÍTULO: Lodos gerados nas estações de tratamento de esgotos no Distrito Federal: um estudo de sua aptidão para o condicionamento, utilização e disposição final.

GRAU: Mestre

ANO: 2015

É concedida à Universidade de Brasília permissão para reproduzir cópias desta dissertação de mestrado e para emprestar ou vender tais cópias somente para propósitos acadêmicos e científicos. $\mathrm{O}$ autor reserva outros direitos de publicação e nenhuma parte dessa dissertação de mestrado pode ser reproduzida sem autorização por escrito do autor.

Lucilene Ferreira Batista

Brasília-DF, Brasil

iii 


\section{Dedicatória}

Sidney, como diz em Cantares: eu sou do meu amado.

E o meu amado é meu.

João Vítor, Ana Laura, Ana Luísa e Luís Felipe,

Filhos, vocês são as alegrias do meu viver.

Mamãe,

Uma mulher forte, batalhadora, sábia, sempre será um exemplo a ser seguido!

A vocês dedico. 


\section{Agradecimentos}

Ao finalizar este trabalho tenho muitos motivos para agradecer, agradecer aos que me apoiaram, aos que me ajudaram, aos que me toleraram, aos que me incentivaram, aos que me desafiaram; não foi fácil, não foi rápido, não foi perfeito, em muitos momentos não foi bom, mas...

Ah! Como foi enriquecedor. Então, invisto essas linhas em meus agradecimentos especiais...

Ao meu marido Sidney, que sempre será meu parceiro de empreitadas, como um dia prometemos: nos bons e maus momentos. Em nossa caminhada, mais que aprender a dividir, temos aprendido a somar e tem sido perfeito! A alegria dessa conquista também é sua, te amo!

Aos meus filhos minha gratidão, pelos sorrisos que iluminam minha vida, pelos abraços despretensiosos que aquecem meu coração. Com vocês tudo fica mais lindo, tem mais cor, tem mais brilho, a vida vale a pena ser vivida!

À minha mãe, minha maior incentivadora, minha âncora, meu porto seguro, sem você não teria conseguido, você é a vovó mais presente e muitas vezes foi uma mãe para meus filhos, por saber que você estava cuidando pude continuar, sabendo que eles estavam em boas mãos. Esse sonho também foi seu e sua realização é meu presente. Te amo mamãe!

Ao meu orientador Marco Antonio, acredito que farei parte de seu recorde, agradeço pela

paciência e orientação, por ter me aceitado e acreditado que conseguiria, agradeço pela compreensão. De uma coisa tenho certeza, fui uma provação que você venceu, mas pense pelo lado bom... dizem que as provações nos fazem mais fortes.

À minha família, a vocês que sempre acreditaram em mim, divido com vocês as alegrias dessa vitória. 
Aos professores e equipe do Programa de Pós-graduação em Tecnologia Ambiental e Recursos Hídricos - Departamento de Engenharia Civil e Ambiental da Universidade de Brasília, pelos ensinamentos e apoio.

À Companhia de Saneamento Ambiental do Distrito Federal - CAESB, pela disponibilização dos dados e por proporcionar minha participação no curso de mestrado.

Aos amigos que me ajudaram, seja direta ou indiretamente, na realização desse trabalho: a Ana Maria Machado, você tem sido uma companheira de caminhada e de ideais; Ana Maria do Carmo Mota como já lhe disse, quando crescer quero ser igual a você; Daidi, você foi um instrumento nas mãos de Deus para que eu pudesse iniciar minha carreira; Carlos Eduardo, por permitir que eu me engajasse nesse projeto; Leonor pela disposição em ajudar e pelos conselhos; Marise, pela ajuda inestimável e a tantos outros que estiveram comigo ao longo do caminho, meus sinceros agradecimentos.

Comecei meus agradecimentos com os amores da minha vida e quero encerrar com Aquele que é a razão do meu viver, ao meu Deus, o Senhor da minha existência, minha eterna gratidão.

Não há conquista que tenha alcançado somente por meus próprios méritos, o Senhor tem sido meu refúgio, a alegria do Senhor tem sido minha força... "uns confiam em carros, outros em cavalos, eu, porém, confio no Senhor dos Exércitos"... que me tem sustentado até aqui.

A meu Senhor e Rei minha adoração, meu louvor e minha gratidão.

"Ó profundidade da riqueza, da sabedoria e do conhecimento de Deus! Quão insondáveis são os seus juízos, e quão inescrutáveis os seus caminhos! Pois, quem conheceu a mente do Senhor? Quem se tornou seu conselheiro? Quem primeiro the deu alguma coisa, para que Ele lhe recompense?

Portanto Dele, por Ele e para Ele são todas as coisas. A Ele seja a glória eternamente! Amém." (Romanos 11:33-36) 


\section{RESUMO}

LODOS GERADOS NAS ESTAÇÕES DE TRATAMENTO DE ESGOTOS NO DISTRITO FEDERAL: UM ESTUDO DE SUA APTIDÃO PARA O CONDICIONAMENTO, UTILIZAÇÃO E DISPOSIÇÃO FINAL.

O Distrito Federal (DF) se destaca no Brasil pelos elevados índices de atendimento por sistemas de esgotamento sanitário. São 16 Estações de Tratamento de Esgotos (ETE) em operação, que empregam tecnologias de tratamento diversificadas e geram diariamente cerca de 300 toneladas de lodo. A gestão adequada do lodo de esgotos constitui-se em um desafio para os projetistas e operadores dos sistemas, pois a disposição final desse resíduo tornou-se um dos problemas ambientais urbanos mais relevantes da atualidade, não apenas pelos grandes volumes gerados, mas também por ser um resíduo de composição variável. Nesse contexto, a presente pesquisa objetivou a caracterização dos processos de geração e tratamento e da qualidade do lodo de esgotos gerado em todas as ETEs do DF, com vistas a identificar as alternativas de disposição final que sejam técnica e ambientalmente viáveis. A ETE Brasília Norte foi selecionada para um estudo de caso detalhado das etapas intermediárias de tratamento de lodo, e a análise dos dados disponibilizados pela CAESB permitiu uma avaliação das variáveis que influenciam o desempenho operacional das unidades de geração e tratamento do lodo, do seu comportamento e das eficiências alcançadas. Isso pode nortear o planejamento de ações para otimização de processos e melhorias operacionais, visando principalmente ao atendimento dos requisitos de qualidade dos lodos para as alternativas de disposição final selecionadas. Os coeficientes de produção de lodo foram verificados e comparados com a literatura clássica, tendo-se deparado com a dificuldade em se estabelecer um padrão de geração de lodo para a fase de tratamento primário, demonstrando a necessidade de se definirem rotinas operacionais que permitam estabelecer os parâmetros para elaboração de cenários de produção de lodo. Foram levantados os requisitos necessários às alternativas de tratamento e de disposição final do lodo, e com a caracterização dos lodos das ETEs do DF, foi construído um cenário em que foram priorizadas as alternativas que propiciam o aproveitamento do lodo. Concluiu-se que, para as características atuais, as alternativas possíveis para uso e disposição dos lodos das ETEs do DF são: recuperação de áreas degradadas, produção de substrato vegetal e codisposição em aterro sanitário. Concluiu-se ainda que um tratamento complementar para higienização do lodo permitiria sua adequação para o uso agrícola.

Palavras-chaves: lodos de esgotos, tratamento de lodos e disposição final, esgotos domésticos. 


\section{ABSTRACT \\ SLUDGE GENERATED IN SEWAGE TREATMENT PLANTS IN FEDERAL DISTRICT: A STUDY ON ITS ABILITY FOR CONDITIONING, USE AND FINAL DISPOSAL.}

The Federal District (DF) stands out in Brazil by the high attendance indices for sewer systems. There are 16 Sewage Treatment Plants (STP) in operation, employing diverse treatment technologies and daily generate about 300 tons of sludge. Proper management of sewage sludge constitutes a challenge for the designers and operators of systems as the final disposal of this waste has become one of the major urban environmental problems of today, not only by the large volumes generated, but also by being a variable composition. In this context, the present study aimed to characterize the processes of generation and treatment and the quality of sewage sludge generated in all the DF STPs, in order to identify the final disposal alternatives that are technically and environmentally viable. STP Brasilia North was selected for a detailed case study of the intermediate steps of sludge treatment, and the analysis of data provided by CAESB allowed an assessment of the variables that influence the operating performance of generating units and sludge treatment, their behavior and the efficiencies achieved. This can guide the planning of actions for process optimization and operational improvements, aiming mainly to meeting the quality requirements of the sludge according to the selected alternatives of disposal. The sludge production rates were checked and compared with the classical literature. It was faced with the difficulty in establishing a pattern of sludge generation to the primary treatment phase, demonstrating the need to define operational routines needed to establish the parameters for the development of future scenarios of sludge production. The requirements to the sludge and final disposal alternative treatment technologies were raised and with the characterization of sludge from the DF STPs, it was composed a scenario in which priority was given to alternatives that provide the sludge utilization. It was concluded that, for the current characteristics, possible alternatives for use and disposal of sludge from the DF STPs are: reclamation, plant substrate production and co-disposal in landfill. It was also concluded that complementary treatment for sludge disinfection would allow their suitability for agricultural use.

Keywords: sewage sludge, sludge treatment; sludge disposal. 


\section{SUMÁRIO}

1. INTRODUÇÃO......................................................................................................1

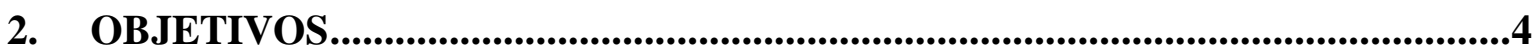

2.1 OBJETIVO GERAL ……..........................................................................................4

2.2 OBJETIVOS ESPECÍFICOS ................................................................................

3. REVISÃO BIBLIOGRÁFICA...........................................................................

3.1 LODOS DE ESGOTOS ……..............................................................................

3.1.1 Características e produção de lodos nos processos de tratamento de

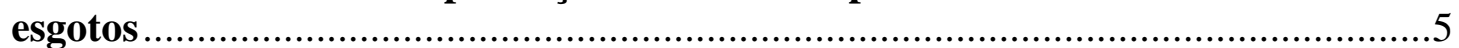

3.1.1.1 Características dos esgotos afluentes ......................................................6

3.1.1.2 Tipos de tratamento e produção típica de lodo............................................

3.1.1.3 Eficiência operacional em tratamentos biológicos .....................................

3.1.2 Aspectos relevantes na caracterização do lodo de esgotos..........................10

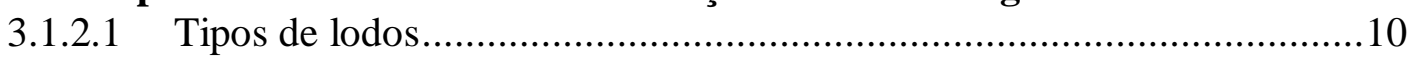

3.1.2.2 Características gerais dos lodos de ETEs ...............................................11

3.1.2.3 Riscos microbiológicos …………………….................................13

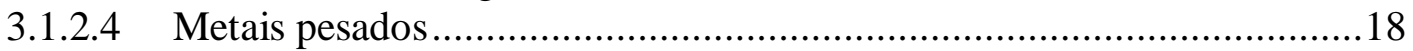

3.1.2.5 Outros compostos potencialmente tóxicos no lodo ………………….....20

3.2 MANEJO DE LODOS DE ETES - TÉCNICAS DE PROCESSAMENTO E CONTROLE 25

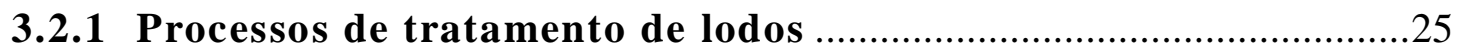

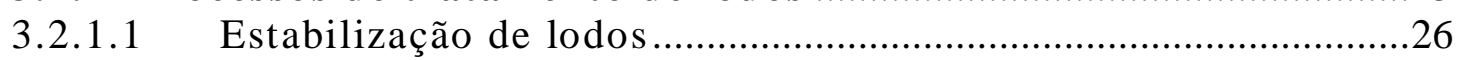

3.2.1.2 Remoção da umidade ....................................................................2

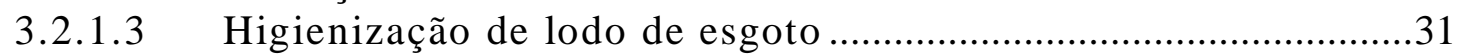

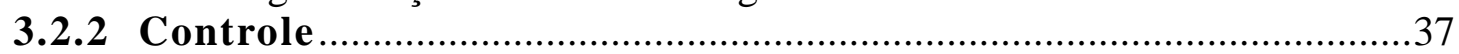

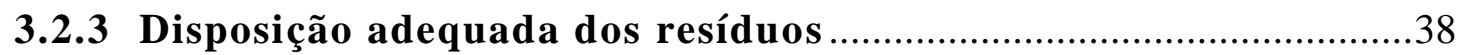

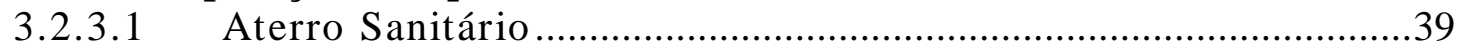

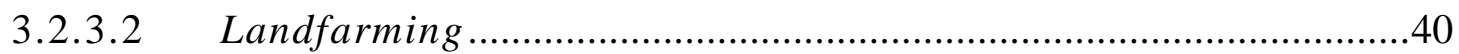

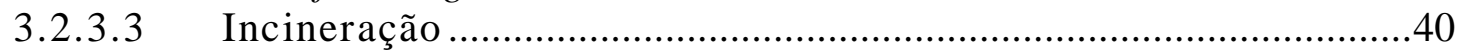

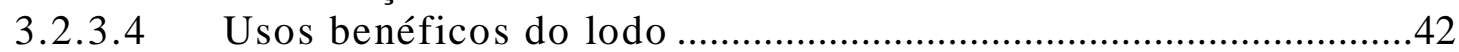

3.3 CONSIDERAÇÕES GERAIS SOBRE A SELEÇÃO DO

TRATAMENTO ADEQUADO DE LODO....................................................52

4 MATERIAIS E MÉTODOS ..............................................................54

4.1 DIAGNÓSTICO DO MANEJO DE LODOS DAS ETES DO DISTRITO

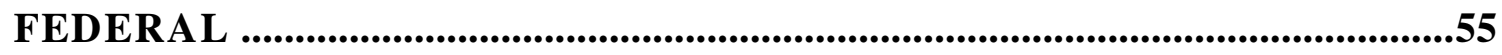

4.1.1 Caracterização qualitativa do lodo desaguado para fins de

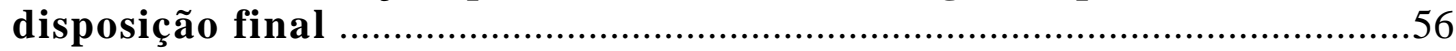

4.1.2 Caracterização quantitativa dos lodos gerados nas ETEs do

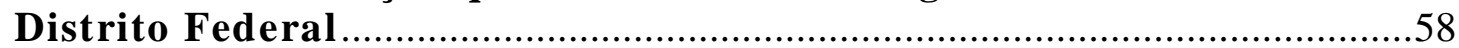

4.2 ESTUDO DE CASO .......................................................................................58

4.2.1 Descrição da Estação de Tratamento Brasília Norte - ETEB Norte .........59

4.2.2 Avaliação do desempenho das unidades de tratamento da fase sólida e do comportamento do lodo ao longo das etapas de geração. ....................................61

4.3 ANÁLISE DO PADRÃO DE PRODUÇÃO DE LODOS DE ESGOTOS NAS

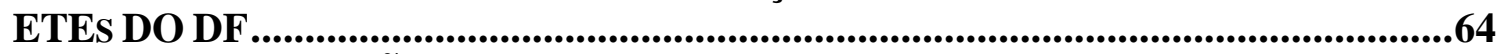
4.4 IDENTIFICAÇÃO DOS USOS POTENCIAIS DOS LODOS DE ESGOTOS, APLICÁVEIS AO DISTRITO FEDERAL .............................................................66 
5. APRESENTAÇÃO E ANÁLISE DE RESULTADOS ......................................69

5.1 GESTÃO DE LODOS NAS ETES DO DISTRITO FEDERAL ........................69

5.1.1 Sistema de Tratamento de Esgotos no Distrito Federal ...........................69

5.1.2 Tecnologias de tratamento de esgotos em operação no Distrito Federal ..70

5.1.3 Características dos esgotos afluentes às estações de tratamentos de esgotos

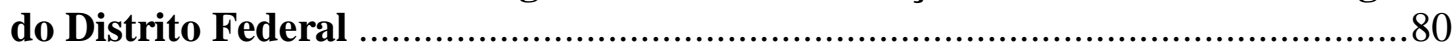

5.1.4 Geração de lodo de esgotos nas ETEs do Distrito Federal .......................85

5.1.5 Produção de lodos de esgotos nas ETEs do DF ......................................992

5.1.6 Características sanitárias dos lodos gerados nas ETEs do Distrito Federal

5.1.7 Características físico-químicas dos lodos gerados nas ETEs do Distrito

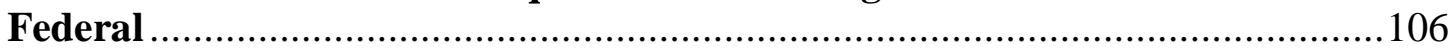

5.1.8 .... Cenário atual do manejo de lodo desaguado das ETEs do Distrito Federal

115

5.2 AVALIAÇÃO DO DESEMPENHO DAS UNIDADES DE TRATAMENTO DA FASE SÓLIDA E DO COMPORTAMENTO DO LODO AO LONGO DAS

ETAPAS DE GERAÇÃO - ESTUDO DE CASO ETE BRASÍLIA NORTE ..........118

5.2.1 Detalhamento do fluxo de tratamento da fase sólida da ETEB Norte ....119

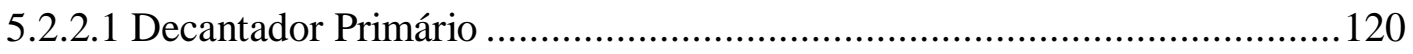

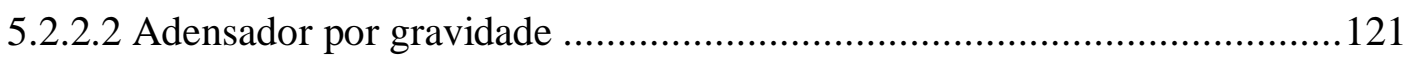

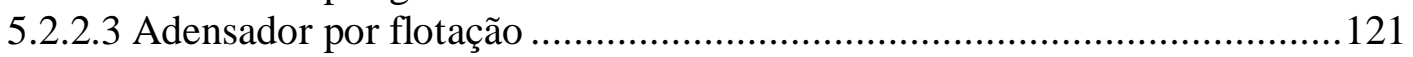

5.2.2.4 Câmara de flotação do polimento final ............................................... 122

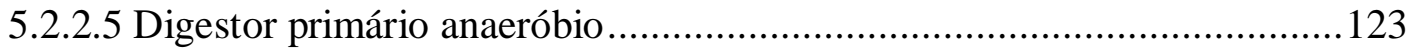

5.2.2.6 Condicionamento e desaguamento de lodo......................................... 124

5.2.3 Avaliação do desempenho das unidades de tratamento da fase sólida e do

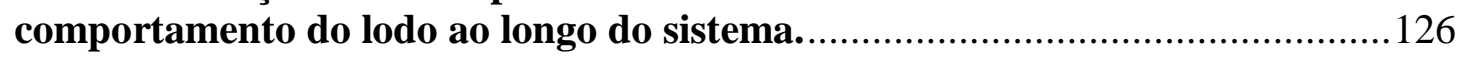

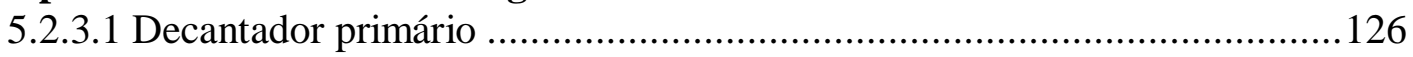

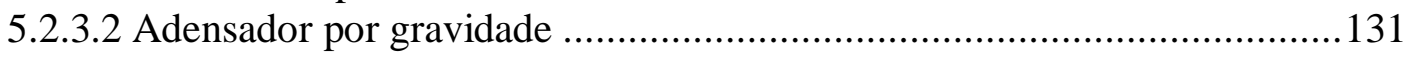

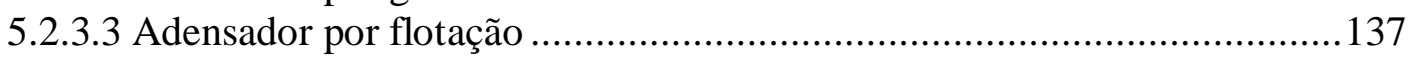

5.2.3.4 Câmaras de flotação do polimento final .............................................. 140

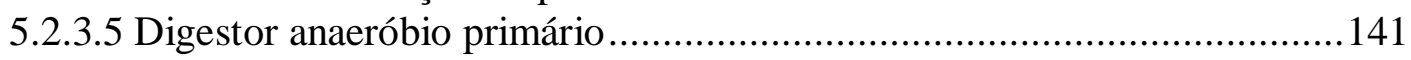

5.2.3.6 Desaguamento do lodo digerido ...................................................... 151

5.3 ANÁLISE DO PADRÃO DE PRODUÇÃ̃O DE LODOS DE ESGOTOS NAS

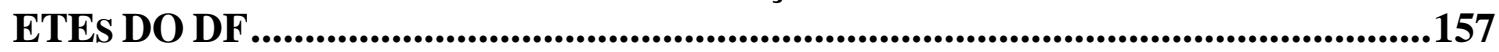

5.3.1 Produção teórica de lodo nas ETEs do Distrito Federal .........................158

5.3.2 Produção real de lodo na ETE Brasília Norte ....................................... 160

5.4 USOS POTENCIAIS E DISPOSIÇÃO FINAL DOS LODOS DE ESGOTOS

APLICÁVEIS AO DISTRITO FEDERAL...............................................................166

5.4.1 Caracterização do Distrito Federal - área, vegetação, solo e clima .........166

5.4.2 Identificação dos usos aplicáveis ao Distrito Federal e análise comparativa

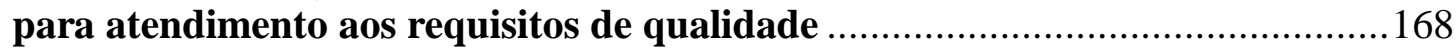

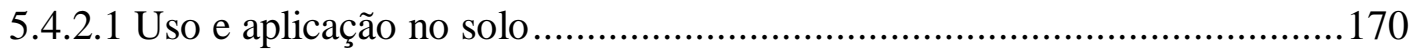

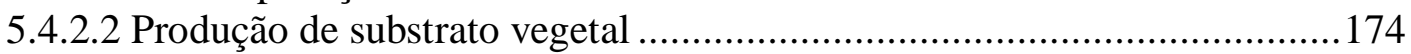

5.4.2.3 Uso como matéria-prima na fabricação de cerâmica vermelha...................176

5.4.2.4 Disposição em Aterro Sanitário................................................................ 177

6. CONCLUSÕES E RECOMENDAÇÕES..............................................178

REFERÊNCIAS BIBLIOGRÁFICAS .................................................................184 


\section{LISTA DE TABELAS}

Tabela3.1 - Produção teórica e características do lodo em função do tipo de Tratamento de Esgoto Utilizado na ETE.

Tabela 3.2 - Classificação de lodos de ETEs.

Tabela 3.3 - Composição química e propriedades típicas do lodo bruto e digerido.

Tabela 3.4 - Concentração de patógenos em lodo produzido em diversas ETEs do Brasil.14 Tabela 3.5 - Grupo/Classe de alguns compostos micropoluentes emergentes de alguns tipos de lodo.

Tabela 3.6 - Faixas usuais de densidades e de massas específicas de alguns tipos de lodo.38

Tabela 3.7 - Principais parâmetros de valor agronômico dos lodos produzidos em ETEs do Brasil .....

Tabela 3.8 - Concentrações máximas permissíveis de metais em lodos de esgoto para aplicação no solo.

Tabela 3.9 - Valores máximos para agentes patogênicos no lodo de esgoto Classe A e B .46

Tabela 4.1 - Parâmetros de caracterização do Lodo

Tabela 4.2 - Metodologias analíticas para determinação dos parâmetros de interesse ......57

Tabela 4.3 - Parâmetros avaliados para o diagnóstico do comportamento do lodo.

Tabela 4.4 - Tabela de variáveis operacionais e formulários aplicados ao estudo de caso da ETEB Norte.

Tabela 5.1 - Tecnologias de tratamento de esgotos aplicados nas ETEs do DF, População, Vazão e Carga Orgânica (real e de projeto) ……......................................................... 71

Tabela 5.2 - Produção absoluta de areia das ETEs do Distrito Federal - ano 2013 ...........74

Tabela 5.3 - Concentrações usuais para esgotos domésticos afluentes, reportados na literatura

Tabela 5.4 - Estatística descritiva referente às concentrações de esgotos afluentes às ETEs do Distrito Federal, agrupados por tecnologias de tratamento similares. ...........................81

Tabela 5.5 - Tipos de lodos gerados nas ETEs do Distrito Federal. .................................86

Tabela 5.6 - Tipos de tratamento de lodo empregados nas ETEs do Distrito Federal. .......86

Tabela 5.7 - Parâmetros e Indicadores de geração de lodo - ano base 2013 ......................93

Tabela 5.8 - Produção de lodo nas ETEs do Distrito Federal - Período 2004 a 2013........96

Tabela 5.9 - Estatística descritiva referente às concentrações de coliformes termotolerantes nos lodos desaguados das ETEs do DF

Tabela 5.10 - Estatística descritiva referente às concentrações de ovos de helmintos e ovos viáveis de helmintos nos lodos desaguados das ETEs do DF.

Tabela 5.11 - Concentração de bactérias no lodo primário e secundário, observadas nos Estados Unidos, em número/g de massa seca. 102

Tabela 5.12 - Indicador de Desenvolvimento Humano - IDH do Distrito Federal, distribuído por Região Administrativa, ano 2003.

Tabela 5.13 - Composição dos lodos de esgotos gerados nas ETEs do DF quanto aos parâmetros agronômicos, expressos em base seca 107 
Tabela 5.14 - Composição dos lodos de esgotos gerados nas ETEs do DF quanto às substâncias inorgânicas, expressos em base seca.

Tabela 5.15 - Composição de lodo de esgotos em diversas ETEs no Brasil e no Distrito Federal.

Tabela 5.16 - Descrição das unidades de tratamento da fase sólida da ETEB Norte. 120

Tabela 5.17 - Estatística descritivas dos teores de ST(\%) no lodo primário na ETEB Norte.

Tabela 5.18 - Parâmetros de projeto do decatador primário da ETEB Norte................... 128

Tabela 5.19- Dados operacionais do decantador primário da ETEB Norte.

Tabela 5.20 - Volumes médios de lodo descartado do decantador primário e Concentrações médias de ST para cada ciclo.

Tabela 5.21 - Estatística descritiva dos teores de ST(\%) no lodo adensado (adensador por gravidade) na ETEB Norte.

Tabela 5.22 - Taxa de aplicação de ST (TAS - $\mathrm{kgST} / \mathrm{m}^{2}$.d) afluentes ao adensador por gravidade da ETEB Norte, entre os anos de 2008 e 2014.

Tabela 5.23 - Estatística descritiva dos parâmetros de controle do lodo químico da ETEB

Norte.

Tabela 5.24 - Carga de sólidos aplicada aos digestores anaeróbios por tipo de lodo, em $\mathrm{KgSS} / \mathrm{d}$.

Tabela 5.25 - Parâmetros operacionais de controle do processo de digestão anaeróbia da ETEB Norte 143

Tabela 5.26 - Variáveis operacionais e parâmetros de controle do processo de desaguamento de lodo.

Tabela 5.27 - Parâmetros adotados para cálculo de produção teórica de lodo: remoção, coeficiente de produção e teor de sólidos

Tabela 5.28 - Parâmetros adotados para cálculo de produção teórica de lodo: remoção e coeficiente de produção.

Tabela 5.29 - Produção teórica de lodo nas ETEs do Distrito Federal considerando a carga orgânica teórica.

Tabela 5.30 - Produção teórica de lodo nas ETEs do Distrito Federal considerando a carga orgânica real aplicada em 2013.

Tabela 5.31 - Volume médio mensal de lodos produzidos diariamente na ETEB Norte, nas diferentes etapas de geração e tratamento.

Tabela 5.32 - Média mensal do Teor de sólidos em suspensão dos diferentes tipos de lodos produzidos diariamente na ETEB Norte, em \%, ano 2013

Tabela 5.33 - Parâmetros operacionais da ETEB Norte e valores de população equivalente e coeficiente de produção de lodos determinados a partir das equações, dados de 2013 .. 162

Tabela 5.34 - Parâmetros operacionais e valores determinados de população equivalente e coeficiente de produção de lodo para os reatores biológicos de lodos ativados da ETEB Norte, dados de 2013. 
Tabela 5.35 - Parâmetros operacionais da ETE Paranoá e valores determinados de população equivalente e coeficiente de produção de lodo no reator UASB, dados de 2014 ... 165

Tabela 5.36 - Alternativas de usos potenciais e disposição final levantadas na literatura.169 Tabela 5.37 - Composição dos lodos gerados nas ETEs do Distrito Federal, segundo os parâmetros restritivos nas Resoluções do CONAMA e CONAM................................... 171

Tabela 5.38 - Composição dos lodos gerados nas ETEs do Distrito Federal - Parâmetros agronômicos 173 


\section{LISTA DE FIGURAS}

Figura 3.1 - Composição do esgoto doméstico.

Figura 3.2 - Principais ovos de helmintos encontrados em biossólido oriundo de tratamento por digestão anaeróbia

Figura 3.3.- Rotas de exposição de fármacos no ambiente.

Figura 4.1 - Fluxograma das etapas e atividades necessárias ao desenvolvimento da pesquisa.

Figura 4.2 - Vista aérea da estação de tratamento de esgotos Brasília Norte.

Figura 4.3 - Fluxograma de tratamento da ETE Brasília Norte.

Figura 4.4 - Representação esquemática dos passos realizados para a identificação das alternativas de manejo de lodo de esgotos.

Figura 5.1 - Concentrações dos esgotos afluentes às ETEs do DF, agrupadas por tecnologias de tratamento de esgotos similares - parâmetro DBO (mg/L) - entre anos $2004-2013$

Figura 5.2 - Concentrações dos esgotos afluentes às ETEs do DF, agrupadas por tecnologias de tratamento de esgotos similares - parâmetro DQO (mg/L) - entre anos $2004-2013$.

Figura 5.3 - Concentrações dos esgotos afluentes às ETEs do DF, agrupadas por tecnologias de tratamento de esgotos similares - parâmetro SS (mg/L) - entre anos 2004 2013

Figura 5.4 - Concentrações dos esgotos afluentes às ETEs do DF, agrupadas por tecnologias de tratamento de esgotos similares - parâmetro TKN (mg/L) - entre anos 2004 $-2013$

Figura 5.5 - Concentrações dos esgotos afluentes às ETEs do DF, agrupadas por tecnologias de tratamento de esgotos similares - parâmetro P-total $(\mathrm{mg} / \mathrm{L})$ - entre anos 2004- 2013.

Figura 5.6 - Carga orgânica removida das ETEs Brasília Sul, Brasília Norte, Melchior, Gama, Riacho Fundo e Paranoá (KgDBO/dia) - 2013 e 2014

Figura 5.7 - Eficiência média de remoção de DBO registradas nas ETEs Brasília Sul, Brasília Norte, Melchior, Gama, Riacho Fundo e Paranoá (\%) - $2013^{1}$ e 2014

Figura 5.8 - Evolução da Produção de Lodo no Distrito Federal (ton/d) entre os anos de 2004 e 2013

Figura 5.9 - Resultados de Coliformes termotolerantes nos lodos desaguados no Distrito Federal (2007 - 2014)

Figura 5.10 - Resultados de coliformes termotolerantes nos lodos desaguados gerados no

Distrito Federal (2007 - 2014) - média anual.

Figura 5.11 - Resultados de ovos de helmintos viáveis nos lodos desaguados, gerados no Distrito Federal (2007 - 2014) - No de ovos viáveis de helmintos/g massa seca 101

Figura 5.12 - Resultados de coliformes termotolerantes nos lodos desaguados gerados no Distrito Federal (2013 - 2014) - média anual. 103

Figura 5.13 - Resultados de parasitologia dos lodos desaguados, gerados no Distrito Federal (2007 - 2014) - No de ovos de helmintos/g massa seca versus IDH. 106 
Figura 5.14 - Concentração de Nitrogênio em experimentos com lodo de ETEs do DF x

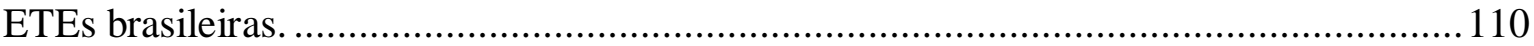

Figura 5.15 - Concentração de Fósforo em experimentos com lodo de ETEs do DF, comparadas a algumas ETEs brasileiras. ............................................................... 110

Figura 5.16 - Concentração de Potássio em experimentos com lodo de ETEs do DF comparadas a algumas ETEs brasileiras.

Figura 5.17 - Concentração de Matéria Orgânica em experimentos com lodo de ETEs do DF x ETEs brasileiras.

Figura 5.18 - Concentração de Cálcio em experimentos com lodo de ETEs do DF x ETEs brasileiras

Figura 5.19 - Concentração de Ferro em experimentos com lodo de ETEs do DF x ETEs brasileiras

Figura 5.20 - Concentração de Magnésio em experimentos com lodo de ETEs do DF x ETEs brasileiras.

Figura 5.21 - Concentração de Zinco em experimentos com lodo de ETEs do DF x ETEs brasileiras.

Figura 5.22 - Concentração de Cobre em experimentos com lodo de ETEs do DF x ETEs brasileiras

Figura 5.23- Evolução das Alternativas de disposição de lodo no DF (2012-2014) ......... 116

Figura 5.24 - Fluxograma da ETE Brasília Norte - Tratamento da fase sólida.

Figura 5.25 - Dispersão de ar na câmara de flotação.

Figura 5.26 - Raspadores de superfície das câmaras de flotação.

Figura 5.27 - Série temporal das concentrações de sólidos ST (\%) no lodo primário

Figura 5.28- Concentração de sólidos ST (\%) no decantador primário - valores mínimos, máximos, mediana e os $1^{\circ}$ e $3^{\circ}$ quartis.

Figura 5.29 - Série temporal dos volumes de lodo descartado diariamente do decantador primário

Figura 5.30 - Distribuição das concentrações do lodo primário, em termos de \%ST, ao longo dos 3 ciclos de extração de lodo testados.

Figura 5.31 - Série temporal dos teores de sólidos totais no adensador por gravidade. ... 131

Figura 5.32 - Box-plot das concentrações de sólidos ST (\%) no adensador por gravidade 132

Figura 5.33 - Série temporal da captura de sólidos no adensador por gravidade

Figura 5.34 - Box-plot das capturas de sólidos ST (\%) no adensador por gravidade....... 133

Figura 5.35 - Série temporal da taxa de aplicação de sólidos (TAS) e captura de sólidos no

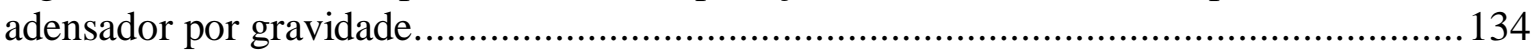

Figura 5.36 - Série temporal de captura de sólidos no adensador no ano de 2014 ........... 136

Figura 5. 37 - Box-plot do tempo de detenção hidráulica no adensador por gravidade.... 136

Figura 5.38 - Box-plot da TAS sólidos no adensador por gravidade 138

Figura 5.39 - Série temporal da TAS sólidos e captura de sólidos dos adensadores por flotação da ETEB Norte.

Figura 5.40 -Volume de lodo químico gerado na ETEB Norte $\left(\mathrm{m}^{3} / \mathrm{d}\right)$ anos 2008 - $2014 \ldots . . .141$ 
Figura 5.41 - Box-plot da concentração de sólidos (\%ST) de lodo químico gerado na

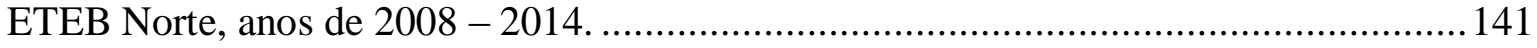

Figura 5.42 - Box-plot da concentração de sólidos totais no lodo digerido ..................... 144

Figura 5.43 - Box-plot da concentração de sólidos totais voláteis no lodo digerido ......... 144

Figura 5.44 - Série temporal das concentrações de sólidos totais e sólidos totais voláteis no

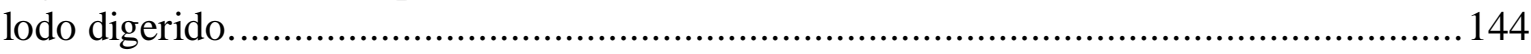

Figura 5.45 - Série temporal do tempo de detenção hidráulica no digestor anaeróbio..... 145

Figura 5.46 - Série temporal de sólidos voláteis e sólidos totais no lodo digerido............ 146

Figura 5.47 - Box-plot do tempo de detenção hidráulica no digestor primário anaeróbio

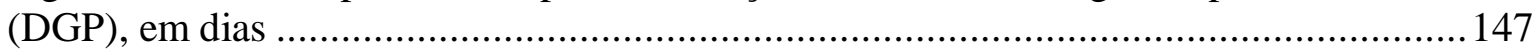

Figura 5.48 - Relação de SV/ST no lodo digerido do DGP da ETEB Norte.................... 147

Figura 5.49 - Eficiência de remoção de sólidos voláteis na digestão de lodo da ETEB

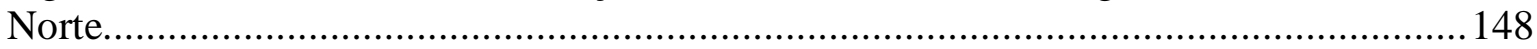

Figura 5.50 - Carga orgânica volumétrica (COV) afluente ao digestor primário anaeróbio

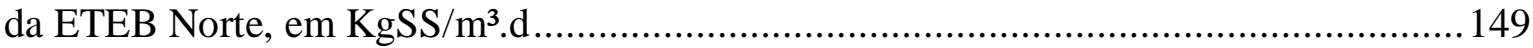

Figura 5.51 - Box-plot do pH no lodo digerido .................................................... 150

Figura 5.52 - Box-plot da relação acidez/alcalinidade no lodo digerido.......................... 150

Figura 5.53 - Série temporal do teor de sólidos (\%) no lodo afluente à desidratação

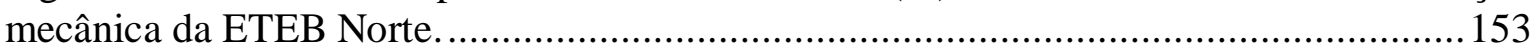

Figura 5.54 - Box-plot da carga hidráulica aplicada às prensas desaguadoras da ETEB

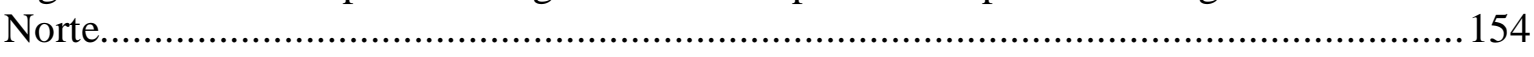

Figura 5.55 - Box-plot do volume de lodo afluente à desidratação mecânica da ETEB

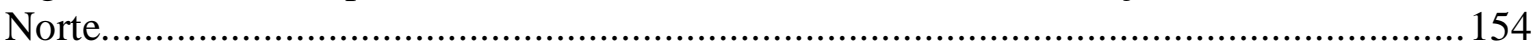

Figura 5.56 - Box-plot do teor de sólidos no lodo desaguado da ETEB Norte................. 155

Figura 5.57 - Box-plot da captura de sólidos no lodo desaguado da ETEB Norte............. 155

Figura 5.58 - Box-plot do consumo de polímero catiônico no condicionamento do lodo afluente à desidratação da ETEB Norte. 156 


\section{LISTA DE SÍMBOLOS}

Al - Alumínio

ANA - Agência Nacional de Águas

Ca - Cálcio

CAESB - Companhia de Saneamento

Ambiental do Distrito Federal

Cd - Cádmio

CETESB - Companhia de Tecnologia de Saneamento Ambiental

$\mathrm{CF}$ - Coliformes Termotolerantes

Co - Cobalto

CODEPLAN - Companhia de

Planejamnto do Distrito Federal

CONAMA - Conselho Nacional do Meio

Ambiente

COV - Carga Orgânica volumétrica

$\mathrm{Cr}$ - Cromo

$\mathrm{Cu}$ - Cobre

DBO - Demanda bioquímica de oxigênio

DF - Distrito Federal

DP - Decantador Primário

DS - Decantador secundário

EMBRAPA - Empresa Brasileira de

Pesquisa Agropecuária

EPA - Agência de Proteção Ambiental

(Estados Unidos)

ES - Escoamento superficial

ETE - Estação de Tratamento de Esgotos

$\mathrm{Fe}$ - Ferro

Hg - Mercúrio

IBGE - Instituto Brasileiro de Geografia e Estatística

LA - Lodos ativados

LAF - Lagoa aerada facultativa

LAMC - Lagoa aerada de mistura completa
LAN - Lagoa anaeróbia

LAP - Lodos ativados aeração prolongada

LF - Lagoa facultativa

LM - Lagoa de maturação

LP - Lagoa de polimento

$m g \mathrm{~kg}^{-1}$ - miligrama por quilograma

$\mathrm{mg} \mathrm{L}^{-1}$ - miligrama por litro

Mg - Manganês

Mo - Molibdênio

$\mathrm{Ni}$ - Níquel

NOVACAP - Companhia Urbanizadora da Nova Capital do Brasil

NT - Nitrogênio total

NTK - Nitrogênio total Kjeldahl

$\mathrm{Pb}$ - Chumbo

PDAD - Pesquisa Distrital por Amostra de Domicílios

$\mathrm{PO}_{4}$ - Fosfato

PRODES - Programa de Despoluição de Bacias Hidrográficas

PROSAB - Programa de Pesquisa em Saneamento Básico

P-total Fósforo total

Se - Selênio

$\mathrm{Si}$ - Silício

SST - Sólidos suspensos totais

ST - Sólidos totais

SV - Sólidos voláteis

TAS - Taxa de aplicação de sólidos

TDH - Tempo de detenção hidráulica

UASB - Upflow anaerobic sludge blanket

Zn - Zinco 


\section{INTRODUÇÃ̃}

A sociedade atual e a comunidade científica têm fomentado o avanço de discussões com respeito às garantias para as gerações futuras de um ambiente saudável, compatibilizando o desenvolvimento às limitações dos recursos naturais.

Dentre os problemas ambientais, agravados pela crescente concentração urbana, um dos mais relevantes da atualidade é, sem dúvida, o destino adequado para os milhões de toneladas de resíduos gerados, diariamente, em todo o mundo.

Neste contexto, a disposição final do lodo, resíduo proveniente do tratamento de esgotos, vem se caracterizando como um desafio para os governantes e profissionais do setor. $\mathrm{O}$ aumento do número de estações de tratamento de esgotos e o consequente incremento da produção de lodos de esgotos torna imperiosa a abordagem do problema.

Os múltiplos aspectos envolvidos, tais como o volume significativo de material gerado, as limitações na localização de áreas para destinação final de resíduos sólidos, o custo elevado para operacionalizar a disposição adequada e aspectos de ordem ambiental e sanitária, tornam a gestão de resíduos do Sistema de Esgotamento Sanitário (SES), bastante complexa.

Mundialmente, as práticas de minimização da produção de resíduos têm sido estimuladas, priorizando a reciclagem como opção de destino final. Por esta razão, o uso do lodo de esgoto na agricultura vem se tornando uma alternativa de grande interesse. Esta possibilidade tem o benefício de transformar um resíduo problemático e de difícil disposição em um insumo agrícola, fornecendo matéria orgânica e nutrientes ao solo. Entretanto, o conhecimento sobre os riscos ambientais e à saúde da população e o aumento das exigências legais sobre as técnicas de manejo do lodo têm sido objeto de diversas discussões e pesquisas para o aprimoramento da gestão do lodo.

Alguns avanços tecnológicos alcançados no tratamento de esgotos apresentam reflexos também no tratamento do lodo, tais como: o emprego de técnicas para o condicionamento e desaguamento do lodo; a utilização de processos térmicos para o seu tratamento; o uso de aterros sanitários controlados, como alternativa para a disposição final dos resíduos do 
tratamento. Esses aperfeiçoamentos, entretanto, conduzem a um acréscimo dos custos operacionais do tratamento.

Diversos autores destacam que os problemas decorrentes da geração de lodo de esgotos requerem soluções tão ou mais complexas que o próprio tratamento de esgotos e podem representar um aumento substancial dos custos totais, cerca de 50\%, se considerados os gastos até a disposição final do lodo (Rulkens,2004; Fernandes e Souza, 2001; Além Sobrinho, 2001).

O Distrito Federal (DF), à luz dessas reflexões, ocupa posição de destaque no panorama nacional, uma vez que, devido aos elevados índices de atendimento à população, pelo sistema de esgotamento sanitário, cerca de $89,7 \%$ da população regularmente instalada no Distrito Federal, apresenta a maior produção per capita de lodo do país.

A Companhia de Saneamento Ambiental do Distrito Federal (CAESB) alcançou, em 2005, a marca de $100 \%$ de tratamento do esgoto coletado, número expressivo, considerando a realidade nacional.

Entretanto, o Distrito Federal está em evidência não apenas pelo volume de lodo gerado, mas também pelo emprego de tecnologias de tratamento diversificadas, que foram combinadas para atender aos elevados níveis de exigência dos corpos receptores da região.

O lodo removido nas diferentes etapas do tratamento de esgoto, devido aos grandes volumes e à composição variável, constitui-se um problema particularmente complexo. É importante o conhecimento dos requisitos necessários à aplicação das técnicas de tratamento disponíveis e das características do lodo, com vistas a alcançar a qualidade desejável a sua correta utilização ou destinação, para melhor orientar as decisões quanto ao seu processamento.

Quanto ao tema da disposição final do lodo, a aplicação agrícola vem sendo discutida como uma proposta viável para o $\mathrm{DF}$, devido às condições do solo da região, pobre em matéria orgânica, e ao potencial do lodo como condicionador de solo e fertilizante. A adoção dessa prática, entretanto, precisa estar amparada pelo conhecimento dos elementos que podem vir a produzir impactos negativos ao ser humano ou ao meio ambiente.

Além disso, do ponto de vista estratégico, a melhor solução deve prever um conjunto de alternativas, evitando-se a dependência de uma única opção. Uma abordagem possível é 
aquela que priorize o aproveitamento do resíduo, mas como alternativa de contingência, aponte um segundo bloco de opções que possibilite sua disposição adequada.

Assim, para permitir o delineamento das alternativas adequadas ao Distrito Federal, é preciso a realização de estudos que aliem a caracterização do lodo, ao conhecimento do seu comportamento, nas diversas etapas de tratamento, e dos requisitos necessários à utilização de cada alternativa de processamento. 


\section{OBJETIVOS}

\subsection{OBJETIVO GERAL}

Avaliar as características dos lodos provenientes das estações de tratamento de esgotos sanitários do Distrito Federal, visando ao diagnóstico da sua aptidão para o condicionamento, utilização e disposição final, considerando as alternativas aplicáveis ao Distrito Federal.

\subsection{OBJETIVOS ESPECÍFICOS}

- Realizar o diagnóstico do manejo de lodos no Distrito Federal-DF, por meio da compilação de dados e informações que compreendam as tecnologias de tratamento empregadas nas Estações de Tratamento de Efluentes- ETEs do DF e a produção de lodo, por tipo de processo, sistematizando os dados de quantidade e qualidade, de forma a facilitar a compreensão do problema e a análise das soluções.

- Caracterizar qualitativa e quantitativamente os diferentes tipos de lodos produzidos, ao longo das etapas de tratamento, classificando-os segundo suas características e processos de geração.

- Avaliar o comportamento do lodo ao longo das etapas de tratamento, confrontando suas características com os requisitos indicados para cada etapa de processamento, com vistas a identificar as alternativas que minimizem a produção e melhorem a qualidade do lodo gerado.

- Verificar o potencial de aproveitamento dos lodos de esgotos gerados nas ETEs da Companhia de Saneamento Ambiental do Distrito Federal (CAESB), considerando as suas características e a demanda da região. 


\section{REVISÃO BIBLIOGRÁFICA}

\subsection{LODOS DE ESGOTOS}

O lançamento dos esgotos "in natura", nos corpos hídricos, provoca interferência direta no ambiente aquático, afetando suas características físicas, químicas e biológicas. Esse impacto é causado, em parte, pelo incremento na disponibilidade de matéria orgânica, que causa o desequilíbrio das interações estabelecidas no ecossistema aquático. Por esta razão, um dos principais objetivos do tratamento das águas residuárias é remover a matéria orgânica presente.

Um dos subprodutos resultantes do processo de tratamento de esgotos é um resíduo que pode apresentar-se na forma sólida, semi-sólida ou líquida, rico em matéria orgânica e em nutrientes, com grande potencial poluidor, denominado lodo de esgoto.

Segundo Jordão e Pessoa (2005), entre os resíduos do processo de tratamento de esgotos, o lodo adquire posição de destaque, merecendo especial atenção não só pelos grandes volumes gerados e por seu potencial de poluição, mas também pela complexidade de seu tratamento e pelos custos advindos de seu manejo adequado.

Para efeito do presente trabalho, é importante definir os termos "lodos de esgoto" e "biossólidos". Lodos são os efluentes sólidos das estações de tratamento de esgoto, não introduzidos nos ciclos de recuperação e reciclagem. Biossólidos são os sólidos, após adequação e tratamento, em qualquer forma, destinados para uso agrícola (Spinosa, 2007). No entanto, em decorrência do largo uso, em bibliografia, do termo "lodos de esgoto", para designar tanto o lodo produzido nos processos de tratamento de águas residuárias, quanto o lodo tratado e condicionado para uso agrícola, nesta dissertação, não será feita esta diferenciação entre biossólidos e lodos de esgotos: ambos os termos serão utilizados como sinônimos.

\subsubsection{Características e produção de lodos nos processos de tratamento de esgotos}

A quantidade e as características dos lodos produzidos, em estações de tratamento de esgotos, são definidas, dentre outros fatores, pela qualidade dos esgotos afluentes, pela 
alternativa de tratamento adotada, assim como pela eficiência operacional do sistema, visto que esta pode resultar em produção menor de lodo.

A seguir, são descritos, de maneira sucinta, os aspectos de maior interesse para o conhecimento da qualidade e produção de lodo oriundo do tratamento de esgotos.

\subsubsection{Características dos esgotos afluentes}

As águas residuárias municipais ou esgotos têm sua origem nas atividades antrópicas, apresentando uma acentuada variação de suas características tanto quantitativas, quanto qualitativas. Esta variabilidade está relacionada, principalmente, à sua origem, à vazão de esgotos coletada, ao sistema de coleta (separador absoluto ou sistema unitário), à extensão e ao estado de conservação das redes coletoras.

Quanto à origem, os esgotos podem ser classificados em: domésticos e industriais. Os esgotos domésticos são constituídos, essencialmente, de despejos domiciliares, provenientes das instalações sanitárias das edificações, como nos centros urbanos não há separação na coleta de esgotos hospitalares e provenientes de setores de serviços, esses também compõe o chamado esgoto doméstico. Outras parcelas constituintes dos esgotos são as águas de infiltração e uma parcela de águas pluviais.

Os esgotos industriais apresentam características com acentuada diversidade, diretamente relacionada aos processos da cadeia produtiva, podendo conter teores de metais pesados e de outros compostos tóxicos bastante indesejáveis aos tratamentos biológicos. Um dos agravantes do lançamento indiscriminado de despejos industriais, no sistema coletor de esgotos sanitários, é a concentração, no lodo, de compostos que inviabilizam os processos de condicionamento e disposição propostos.

As características físicas, químicas e biológicas dos esgotos sanitários são bastante variadas, entretanto, sua composição, em termos percentuais, apresenta as seguintes parcelas: $99,8 \%$ a 99,9\% de água e 0,01 a $0,02 \%$ de sólidos, sendo que do total de sólidos, $70 \%$ são orgânicos e 30\% inorgânicos (Figura 3.1) (Melo e Marques, 2000). Os sólidos podem ser classificados, segundo seu tamanho e estado, em sólidos em suspensão (SS) ou dissolvidos (SD); segundo suas propriedades químicas, em voláteis ou fixos e, segundo suas propriedades de sedimentação, em sedimentáveis e em não sedimentáveis. A fração sólida é formada por compostos orgânicos (proteínas, carboidratos, óleos e graxas etc), 
nutrientes (nitrogênio e fósforo), metais, sólidos inertes, sólidos inorgânicos, compostos não biodegradáveis, organismos patogênicos e, em alguns casos, contaminantes tóxicos decorrentes de atividades industriais ou aportes acidentais às redes coletoras.

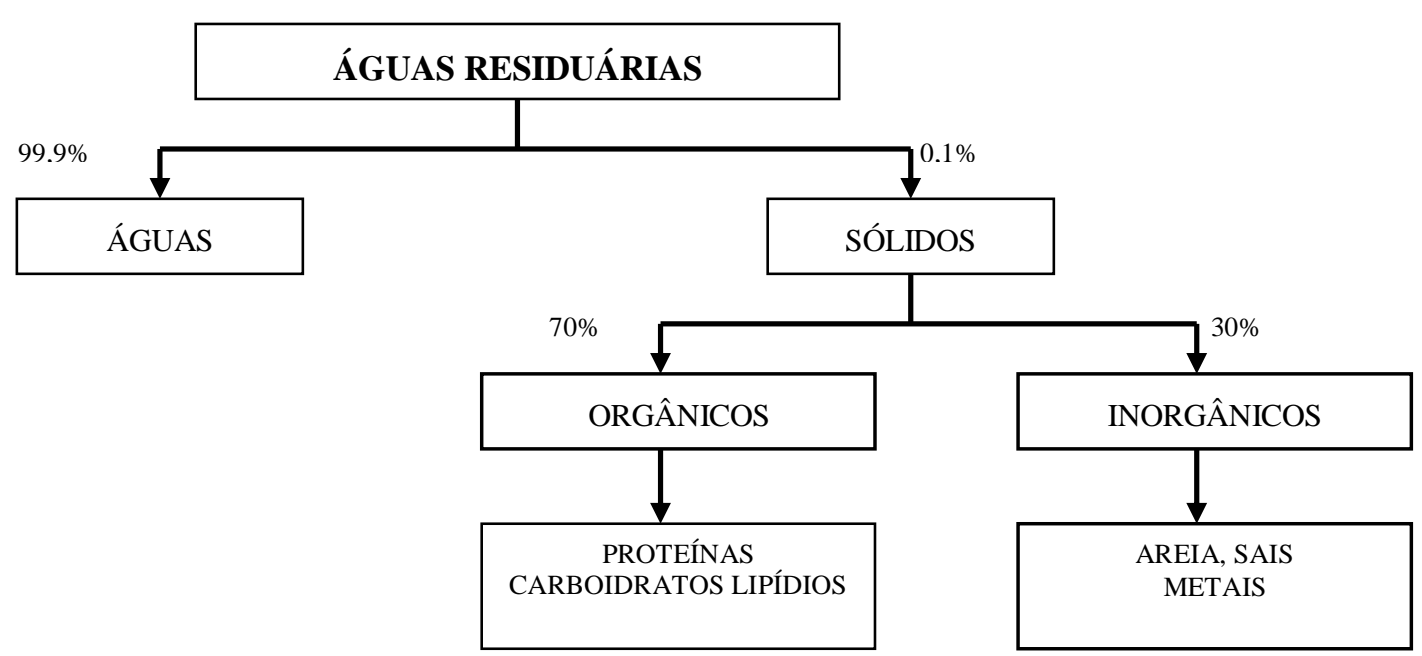

Figura 3.1 - Composição do esgoto doméstico

Fonte: adaptado de Melo e Marques (2000)

Quanto às características biológicas, nos esgotos sanitários são encontrados diversos organismos: bactérias, fungos, vírus, protozoários, entre outros. Estes são responsáveis por viabilizar os processos de decomposição e a estabilização da matéria orgânica. A componente biológica, entretanto, destaca-se não apenas por seus efeitos benéficos, mas também por representar a característica de interesse sanitário, considerando-se os riscos epidemiológicos pela presença de agentes patogênicos.

\subsubsection{Tipos de tratamento e produção típica de lodo}

Os tratamentos baseados em processos biológicos têm se firmado como os de maior interesse para as águas residuárias de origem doméstica. Essa preferência reside no fato de que eles são tecnologias exaustivamente estudadas, cuja essência é a reprodução de fenômenos e processos observados na natureza, para que, em condições controladas, seus efeitos sejam maximizados, acelerando a decomposição dos resíduos, com resultados satisfatórios e a um menor custo.

O tratamento biológico viabiliza a remoção das substâncias orgânicas biodegradáveis (coloidais ou dissolvidas) e, em alguns casos, de nutrientes (nitrogênio e fósforo), a partir 
de reações químicas promovidas por micro-organismos anaeróbios, aeróbios e facultativos que assimilam a matéria orgânica (Metcalf \& Eddy, 1991).

A produção de lodo apresenta elevada variabilidade de acordo com o tipo de tratamento empregado. Segundo Campos (2000), de maneira geral, a cada pessoa corresponde uma produção diária de lodo, para os processos aeróbios, da ordem de 20 a 35 g de sólidos secos e, para os processos anaeróbios, de 3 a 15 g de sólidos secos. Jordão e Pessoa (2005) comentam que, por meio de uma operação de "balanço de massa" de uma ETE, pode ser estimada a quantidade de sólidos retidos ou gerados no sistema. A Tabela 3.1 relaciona as características dos lodos gerados, bem como a produção per capita, por processo de tratamento.

A gestão de lodo em uma ETE visa principalmente orientar as melhores práticas para o seu manejo, de maneira a se alcançar a redução dos volumes gerados e adequar as características do lodo para as etapas de processamento as quais será submetido, sempre vislumbrando a alternativa de disposição final a ser aplicada.

Tabela3.1 - Produção teórica e características do lodo em função do tipo de Tratamento de Esgoto Utilizado na ETE.

\begin{tabular}{|c|c|c|c|c|c|}
\hline $\begin{array}{l}\text { Origem do } \\
\text { Lodo }\end{array}$ & $\begin{array}{c}\text { Produção } \\
\text { de Lodo } \\
\text { gSS/hab.dia }\end{array}$ & $\begin{array}{l}\text { Teor de } \\
\text { Sólidos } \\
(\% \text { ST) }\end{array}$ & Estabilidade & Aspecto & Desaguamento \\
\hline $\begin{array}{l}\text { Decantador } \\
\text { Primário }\end{array}$ & 35 a 45 & 2 a 6 & $\begin{array}{c}\text { Necessita } \\
\text { estabilização }\end{array}$ & $\begin{array}{l}\text { Marrom a marrom } \\
\text { escuro, aparência } \\
\text { floculenta, odor } \\
\text { pouco ofensivo, } \\
\text { tende a tornar-se } \\
\text { séptico e gerar } \\
\text { odores rapidamente }\end{array}$ & Boa \\
\hline $\begin{array}{l}\text { Aeração } \\
\text { Prolongada }\end{array}$ & 38 a 45 & 0,8 a 1,2 & Estabilizado & \multirow{6}{*}{$\begin{array}{l}\text { Negro, aparência } \\
\text { floculenta, odor } \\
\text { não ofensivo }\end{array}$} & Regular \\
\hline UASB & 7 a 18 & 3 a 6 & Estabilizado & & Boa \\
\hline $\begin{array}{l}\text { Filtro Anaeróbio } \\
\text { (após UASB) }\end{array}$ & 3 a 9 & $0,5 \mathrm{a} 4$ & Estabilizado & & Boa \\
\hline $\begin{array}{l}\text { Lagoas } \\
\text { Anaeróbias }\end{array}$ & 13 a 45 & 15 a 20 & Estabilizado & & Boa \\
\hline $\begin{array}{l}\text { Lagoas } \\
\text { Facultativas }\end{array}$ & 20 a 25 & 10 a 20 & Estabilizado & & Boa \\
\hline $\begin{array}{ll}\text { Lagoas } & \text { de } \\
\text { Maturação } & \end{array}$ & 3 a 20 & 10 a 20 & Estabilizado & & Boa \\
\hline $\begin{array}{l}\text { Filtro Biológico } \\
\text { de Alta Taxa - } \\
\text { Lodo } \\
\text { Secundário }\end{array}$ & 2030 & 1 a 3 & $\begin{array}{c}\text { Necessita } \\
\text { estabilização }\end{array}$ & & \\
\hline $\begin{array}{l}\text { Lodo ativado } \\
\text { convencional }\end{array}$ & 60 a 40 & 0,2 a 0,4 & & & \\
\hline
\end{tabular}

Fonte: Adaptado de Além Sobrinho (2001) e von Sperling (2002) 
Como tanto a quantidade quanto a qualidade do lodo produzido por uma ETE dependem não apenas da vazão e das características do esgoto, mas também do tipo de tratamento e da operação da ETE, é possível utilizar a produção do lodo como um referencial da eficiência de operação, à medida que o conhecimento da produção esperada de lodo para cada tipo de tratamento, pode indicar se os descartes de lodo do sistema estão abaixo ou acima do ideal. Além disso, o aspecto do lodo, apesar de não ser um parâmetro mensurável é um indicador do grau de estabilização do material.

\subsubsection{Eficiência operacional em tratamentos biológicos}

O desempenho dos processos de tratamento biológicos apresenta uma relação de dependência direta com as práticas operacionais, empregadas nas estações de tratamento. Dentre as variáveis operacionais, a de maior relevância, sem dúvida, é a idade de lodo, visto que essa define a proporção de massa de lodo disponível para o metabolismo bacteriano, ou seja, a proporção do material biodegradável e a massa bacteriana presente no sistema de tratamento.

Nos sistemas aeróbios, a idade do lodo influi não somente na produção de lodo, mas também, na sua composição: quanto maior a idade de lodo, maior seu grau de estabilização. Isto decorre do fato de que a população de bactérias, atuantes no processo metabólico de utilização da matéria orgânica, será maior, transformando a DBO afluente em massa bacteriana. Por outro lado, quanto menor a idade de lodo, maior será a fração volátil do lodo, resultando em diminuição da estabilidade, aumento do potencial de atrair vetores disseminadores de doenças e dificuldade em separar a água dos sólidos.

No caso de reatores anaeróbios, Campos (1999) destaca que a determinação de uma frequência de descarte adequada resultará, diretamente, em menores concentrações de sólidos no efluente final, em consequência, em uma melhor qualidade em termos de SS, de DQO e DBO particuladas. Outro aspecto favorável da adoção de descartes de lodo otimizados é uma geração menor de lodo.

Outras rotinas operacionais também influenciam a eficiência dos processos de tratamento, entre elas estão aquelas que envolvem as operações unitárias como o gradeamento e a desarenação. A remoção de sólidos grosseiros e de areia do sistema protege as unidades subsequentes, evitando perda de volume útil nos reatores e os prejuízos em função das remoções, impactando positivamente a qualidade do lodo gerado. 


\subsubsection{Aspectos relevantes na caracterização do lodo de esgotos}

As características do lodo afetam diretamente os processos de tratamento e disposição final, o conhecimento de suas características é fundamental para se definir as linhas mestras de manejo do lodo.

\subsubsection{Tipos de lodos}

Os processos de tratamento de esgotos podem dar origem a diferentes tipos de lodo, variando conforme as tecnologias empregadas, as etapas intermediárias do processo, a alternativa de estabilização e o condicionamento do lodo.

Como o tipo de lodo é função do sistema de tratamento da fase líquida, quanto mais complexo for o fluxograma de uma estação, maior será a variabilidade do lodo produzido.

Dessa forma, em estações onde o esgoto bruto é recebido nos decantadores primários, são gerados o lodo primário, constituído de sólidos sedimentáveis, na etapa biológica é gerado o lodo secundário ou biológico, se os lodos primário e secundário forem enviados para o tratamento conjuntamente, tem-se o lodo misto e assim por diante. Na Tabela 3.2 apresenta-se uma classificação dos tipos de lodo relacionando-os com o processo que lhes deu origem e suas características.

A compreensão das variedades de lodos existentes é de relevante interesse para a definição dos tratamentos mais adequados a cada tipo de lodo. Para cada tratamento, deve-se levar em consideração as características desejáveis para o lodo, os requisitos de qualidade exigidos, com vistas à alternativa de destinação elegida, e a redução de volume, objetivo perseguido em todas as etapas de manejo do lodo. 
Tabela 3.2 - Classificação de lodos de ETEs

\begin{tabular}{|c|c|c|}
\hline Tipo de lodo & Origem & Características \\
\hline $\begin{array}{l}\text { Lodo primário } \\
\text { ou bruto }\end{array}$ & $\begin{array}{l}\text { Proveniente do tratamento primário do } \\
\text { esgoto e obtido, normalmente, por } \\
\text { sedimentação. }\end{array}$ & $\begin{array}{l}\text { Possui uma coloração acinzentada, é pegajoso, } \\
\text { de odor desagradável e pode decompor-se } \\
\text { facilmente. }\end{array}$ \\
\hline Lodo digerido & Processos de estabilização de lodos. & $\begin{array}{l}\text { Apresenta redução de SSV superior a } 40 \% \text {, } \\
\text { dependendo do processo empregado. Quando } \\
\text { bem digerido não possui odor ofensivo. }\end{array}$ \\
\hline $\begin{array}{l}\text { Lodo aeróbio } \\
\text { não } \\
\text { estabilizado }\end{array}$ & $\begin{array}{l}\text { Sistemas de lodos ativados e em reatores } \\
\text { aeróbios com biofilmes - alta carga (von } \\
\text { Sperling e Gonçalves, 2001). }\end{array}$ & $\begin{array}{l}\text { Compreende a biomassa de micro-organismos } \\
\text { aeróbios, gerada nos processos metabólicos de } \\
\text { degradação da matéria orgânica, descartada do } \\
\text { sistema. Necessita de processo de digestão } \\
\text { complementar. }\end{array}$ \\
\hline $\begin{array}{l}\text { Lodo aeróbio } \\
\text { estabilizado }\end{array}$ & $\begin{array}{l}\text { Lodos ativados com aeração prolongada e } \\
\text { reatores aeróbios com biofilmes - baixa } \\
\text { carga (von Sperling e Gonçalves, 2001) }\end{array}$ & $\begin{array}{l}\text { Constitui o lodo excedente, resultante de } \\
\text { respiração endógena prevalecente, com um } \\
\text { menor teor de matéria orgânica e maior } \\
\text { quantidade de sólidos inorgânicos, não havendo } \\
\text { necessidade de uma etapa posterior de digestão. }\end{array}$ \\
\hline $\begin{array}{l}\text { Lodo } \\
\text { anaeróbio } \\
\text { estabilizado }\end{array}$ & $\begin{array}{l}\text { Processos de degradação da matéria } \\
\text { orgânica, em condições anaeróbias. } \\
\text { Ocorrência em reatores anaeróbios e no } \\
\text { fundo de lagoas de estabilização. }\end{array}$ & $\begin{array}{l}\text { Lodo com menor teor de matéria orgânica, } \\
\text { quanto melhor a digestão, menor o potencial de } \\
\text { geração de odor. }\end{array}$ \\
\hline Lodo misto & $\begin{array}{l}\text { Tratamento conjunto de lodos excedentes, } \\
\text { de origem em tratamentos primário e } \\
\text { secundário. }\end{array}$ & $\begin{array}{l}\text { Suas características são uma composição dos } \\
\text { lodos que lhe deram origem. }\end{array}$ \\
\hline Lodo químico & $\begin{array}{l}\text { Produzido em estações de tratamento } \\
\text { onde se tem uma etapa físico-químico de } \\
\text { tratamento da fase líquida. }\end{array}$ & \\
\hline
\end{tabular}

Fonte: adaptado de von Sperling e Gonçalves (2001); Ferreira et al(1999).

\subsubsection{Características gerais dos lodos de ETEs}

O lodo é constituído, em boa parte, por bactérias vivas (Fernandes, 2000). No lodo aeróbio, a fração de massa bacteriana é elevada (dependendo da idade do lodo, 50\% a 90\% da biomassa), enquanto no lodo anaeróbio esta fração está na faixa de 2 a 20\% (Aisse et al., 1999).

Na maior parte das etapas do seu manuseio, o lodo é constituído de mais de $95 \%$ de água, com uma concentração de sólidos, da ordem de 0,25 a $12 \%$ do lodo, em peso. Apenas por convenção, o lodo é designado por fase sólida, visando distingui-lo do fluxo do líquido que está sendo tratado (Metcalf \& Eddy, 1991). 
Durante o processo de digestão, o lodo perde cerca de $2 / 3$ de matéria orgânica. Após a digestão, os sólidos presentes no lodo são constituídos por $45 \%$ de matéria orgânica e $55 \%$ de substâncias minerais. A composição típica do lodo bruto e digerido é mostrada na Tabela 3.3.

Tabela 3.3 - Composição química e propriedades típicas do lodo bruto e digerido.

\begin{tabular}{|c|c|c|c|c|}
\hline \multirow{2}{*}{ Item } & \multicolumn{2}{|c|}{ Lodo bruto } & \multicolumn{2}{|c|}{ Lodo digerido } \\
\hline & Faixa & Típico & Faixa & Típico \\
\hline $\mathrm{pH}$ & $5,0-8,0$ & 6,0 & $6,5-7,5$ & 7,0 \\
\hline Alcalinidade $\left(\mathrm{mg} / \mathrm{L} \mathrm{em} \mathrm{CaCO}_{3}\right)$ & $500-1500$ & 600 & $2500-3000$ & 3000 \\
\hline Ácidos orgânicos (mg/L em HAc) & $200-2000$ & 500 & $100-600$ & 200 \\
\hline Sólidos totais (ST) & $2-8$ & 5 & $6-12$ & 10 \\
\hline Sólidos voláteis (\%ST) & $60-80$ & 65 & $30-60$ & 40 \\
\hline Graxas e gorduras solúveis em éter (\%ST) & $6-30$ & - & $5-20$ & 18 \\
\hline Proteínas $(\% \mathrm{ST})$ & $20-30$ & 25 & $15-20$ & 18 \\
\hline Nitrogênio (N, \%ST) & $1,5-4,0$ & 2,5 & $1,6-6,0$ & 3,0 \\
\hline Fósforo $\left(\mathrm{P}_{2} \mathrm{O}_{5}, \% \mathrm{ST}\right.$ & $0,8-2,8$ & 1,6 & $1,5-4,0$ & 2,5 \\
\hline Potássio $\left(\mathrm{K}_{2} \mathrm{O}, \% \mathrm{ST}\right)$ & $0,0-1,0$ & 0,4 & $0,0-3,0$ & 1,0 \\
\hline Celulose (\%ST) & $8-15$ & 10 & $8-15$ & 10 \\
\hline Ferro (exceto na forma de sulfeto) & $2,0-4,0$ & 2,5 & $3,0-8,0$ & 4,0 \\
\hline Sílica $\left(\mathrm{SiO}_{2}, \% \mathrm{ST}\right)$ & $15-20$ & - & $10-20$ & - \\
\hline
\end{tabular}

Fonte: adaptado de Metcalf \& Eddy (1991).

Nos sistemas de tratamento de esgoto, o lodo produzido concentra os nutrientes, a matéria orgânica, os metais pesados, os organismos patogênicos e outros elementos que podem oferecer risco à saúde e ao meio ambiente, caso não sejam controlados e monitorados adequadamente.

A matéria orgânica presente no lodo pode ser expressa em termos da concentração de sólidos em $\mathrm{mg} / \mathrm{L}$, teor de sólidos secos em percentagem, ou representada pela relação sólidos voláteis/sólidos totais, em \% SV/ST. O teor de sólidos do lodo gerado nas estações de tratamento de esgotos domésticos costuma apresentar faixas típicas de variação de acordo com o próprio tipo de lodo (Tabela 3.1). Valores típicos para lodo gerado em estações de tratamento de esgotos domésticos estão na faixa de 75 a 85\% SV/ST (Jordão e Pessoa, 2005).

O teor de nutrientes (N, P e micronutrientes) e o conteúdo de matéria orgânica presentes no lodo têm importância maior nos casos de aplicação no solo ou uso para produção de fertilizantes. Normalmente, os teores de nutrientes presentes no lodo de esgoto são 
superiores aos encontrados na maioria dos materiais orgânicos de uso habitual na agricultura (Pegorini e Andreoli, 1999).

\subsubsection{Riscos microbiológicos}

O lodo de esgoto contém diversos micro-organismos. Estes podem ser saprófitos, comensais, simbiontes ou parasitas, sendo esta última categoria patogênicacapaz de causar doenças ao ser humano, por meio de contato direto ou por meio de vetores (ratos, pássaros, moscas) que tenham contato com o lodo.

A sanidade do lodo está intrinsecamente relacionada com o perfil da saúde da população que gerou o esgoto, com o tipo de organismo biológico, nele contido, e com as condições ambientais às quais é submetido. Entre as condições que influenciam a concentração de patógenos presentes, no lodo, destacam-se o tipo de tratamento a que o esgoto e o lodo foram submetidos, também influenciam no resultado do grau de sanidade atribuído a um lodo, o método de estocagem, o tempo de permanência nos locais de estocagem, o clima ou estação do ano.

Os agentes bacterianos mais freqüentes são: Salmonella spp., Shigella sp., Escherichia coli, Vibrio cholarae, Leptosira sp. Dentre os agentes virais podem ser citados: vírus da hepatite A, rotavírus, enterovírus, e reovírus. Quanto aos protozoários, são encontrados: Cryptosporidium, Entamoebahistlytica, Giárdia lambia, Balantidium coli e Toxoplasma gondii. Os helmintos mais frequentes são: Ascaris lumbricoides, Ascaris sum, Toxocara sp., Trichuristrichiura, Taeniasolium, Taeniasaginata, Necator americanus e Hymenolepis nanam, Hymenolepis diminuta (USEPA, (1992); Soccol et al., 2010)

Na Tabela 3.4, são apresentados os resultados de determinação de patógenos em lodos produzidos em ETEs brasileiras. 
Tabela 3.4 - Concentração de patógenos em lodo produzido em diversas ETEs do Brasil

\begin{tabular}{|c|c|c|c|c|}
\hline \multirow[b]{2}{*}{ ETE } & \multicolumn{4}{|c|}{ Concentração de patógenos } \\
\hline & $\begin{array}{c}\text { Coliformes } \\
\text { fecais NMP/g }\end{array}$ & Salmonellasp NMP/4g & $\begin{array}{l}\text { Ovos Helmintos } \\
\text { viáveis } / 4 \mathrm{~g}\end{array}$ & $\begin{array}{c}\text { Cistos de } \\
\text { protozoários NMP/g }\end{array}$ \\
\hline ETE Barueri $^{1}$ & 5,4 & Ausente & 1,25 & Ausente \\
\hline ETE Barueri $^{2}$ & 475000 & 36,5 & Ausente & Ausente \\
\hline ETE Suzano $^{1}$ & $<3,0$ & Ausente & $\begin{array}{c}\text { Presente em } 25 \% \text { das } \\
\text { amostras }\end{array}$ & Ausente \\
\hline ETE ABC $^{1}$ & 1250 & ND & ND & ND \\
\hline ETE Lavapés $^{3}$ & 138 & Ausente & ND & ND \\
\hline ETE Franca $^{2}$ & 760000 & 3,1 & 1,4 & 0,2 \\
\hline ETE Belém & 864000 & $\begin{array}{c}\text { Presente em } 17 \% \text { das } \\
\text { amostras }\end{array}$ & 17,2 & 0,1 \\
\hline
\end{tabular}

Notas: (1) Condicionamento do lodo com cal e cloreto Férrico; (2) Condicionamento do lodo com polímero; (3) Condicionamento do biossólido com cal a $20 \%$

Fonte: Tsutiya (2001a)

Em se tratando de organismos patogênicos, os helmintos despertam um grande interesse, isto porque o ambiente encontrado, nos processos de tratamento de esgotos, é propício ao embrionamento de seus ovos. No lodo, a sobrevivência, em temperaturas de $20^{\circ}$ a $30^{\circ} \mathrm{C}$, pode ser de meses.

Os ovos de helmintos têm se mostrado mais resistentes aos diferentes tipos de tratamentos de esgotos empregados, tais como a desinfecção com cloro, irradiação ultra-violeta (UV), ozônio, dentre outros. Alguns gêneros, como Ascaris, Toxocara e Tricuris, são extremamente resistentes à ampla variedade de condições físicas e químicas, sendo capazes de permanecer viáveis, em condições de sombra e umidade, por dois até sete anos, no solo (Bettiol e Camargo, 2006; Who, 2006; Corrêa et al., 2007; Soccol et al, 2010)

Dentre as bactérias entéricas patogênicas encontradas no esgoto, a Salmonela spp e a Shigella spp representam o maior risco de infecção para humanos, já que são mais encontradas em esgotos domésticos (Andreoli et al., 2003).

Paulino et al. (2001) estudaram a prevalência e a viabilidade de ovos e larvas de helmintos e cistos de protozoários presentes em biossólidos e em esgotos submetidos ao tratamento em reatores anaeróbios de leito fluidizado (RALF), na região metropolitana de Curitiba, Paraná. Os autores relataram que houve diferença significativa quanto ao número de ovos viáveis de helmintos presentes no material de quatro estações estudadas. A redução da viabilidade dos ovos de helmintos variou de 59,7 a 93\%. Segundo as conclusões dos autores, novos tratamentos higienizantes são necessários para a utilização do lodo 
produzido, por digestão anaeróbia, na agricultura ou para outros objetivos visando reduzir o risco para saúde humana e animal.

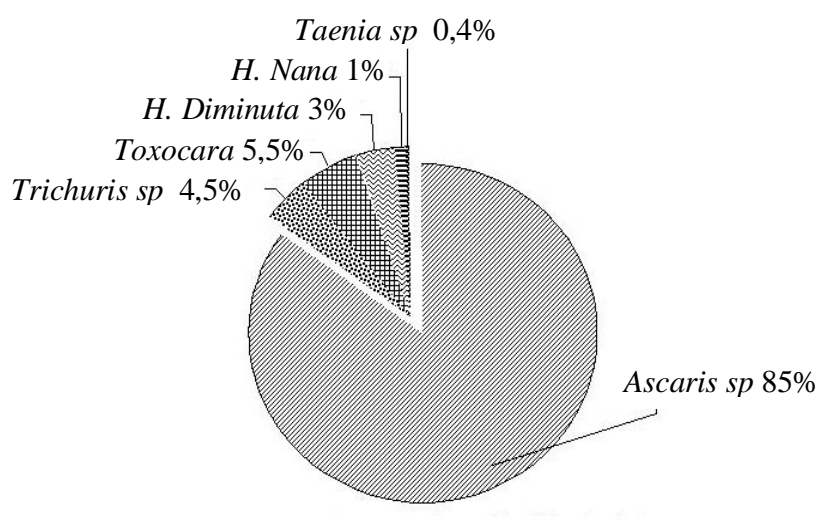

Figura 3.2 - Principais ovos de helmintos encontrados em biossólido oriundo de tratamento

Fonte: Paulino et al. (2001) por digestão anaeróbia.

Nota: Os resultados apresentam as médias aritméticas dos dados obtidos em quatro reatores de leito fluidizado, estudados na região metropolitana de Curitiba, Paraná.

Pires (2003) avaliou a presença de organismos patogênicos no solo e no líquido percolado que recebeu aplicação de lodo em diferentes dosagens. Neste experimento, além de helmintos e protozoários, foram feitas análises de coliformes totais e E. coli. Os resultados obtidos, para aplicação de lodo no solo, demonstraram que: os patógenos concentraram-se na camada superficial do solo $(0-20 \mathrm{~cm})$; quanto maior a dose de lodo aplicada, maior a concentração destes organismos. No líquido percolado, não foram detectados patógenos. Segundo concluiu o autor, a dose de aplicação recomendada é a de 2,5 SST/ha a cada 40 dias, para garantir que não haja riscos de contaminação pela presença de patógenos.

Souza et al. (2008) avaliaram a sobrevivência dos ovos de helmintos no solo após a incorporação do lodo em um Latossolo Vermelho distrófico argiloso do Cerrado. Inicialmente, foi determinada a concentração de ovos de helmintos viáveis presentes no lodo de esgotos produzidos na ETEB Sul (Brasília - DF). Posteriormente, o lodo foi incorporado ao solo e foram feitas amostragens. Durante o período de amostragem, não foi realizado plantio de culturas, sendo observada uma tendência de queda na concentração, desde o primeiro dia da incorporação do lodo até o décimo sexto dia $\overline{\text { e }}$, a partir desta data até o trigésimo dia, não foram recuperados ovos viáveis de helmintos nas amostras. 
Tendência semelhante, de decréscimo de viabilidade dos ovos de helmintos, foi verificada por Lemainski et al. (2007), em cultivo de milho e soja, depois da aplicação de 60 mg.ha ${ }^{-1}$, base úmida, de lodo de esgoto, em solo do Cerrado. A redução, em menor magnitude, do número de ovos de helmintos viáveis no solo, também foi constatada por Soccol et al. (2001) em experimento realizado na Fazenda Experimental do Cangüiri da UFPR, utilizando lodo digerido aeróbio incorporado ao solo, na mesma dose. O lodo digerido continha 7,87 ovos de helmintos viáveis por grama de sólidos totais. O número de ovos viáveis de helmintos nos tempos: inicial (12 horas depois da incorporação), 40 e 180 dias, depois da incorporação, foi de 0,89, 0,19 e 0,03 ovos por grama de sólidos totais, respectivamente.

Uma análise dos resultados, entre os diferentes experimentos mencionados acima, conduz à reflexão sobre algumas causas prováveis para os níveis distintos de redução de sobrevivência dos patógenos, entre elas: as condições locais da aplicação no solo, relacionadas aos processos de dessecação e insolação, devido à influência do clima, e a competição com organismos do solo.

Uma alternativa mais barata, capaz de propiciar a redução de patógenos no lodo, proposta por Popat et al. (2010), é a digestão anaeróbia termofílica. Para melhor estabelecer a relação tempo de retenção e temperatura, os autores inocularam ovos de Ascaris suum (inoculados $10^{4}$.(4g.ST ${ }^{-1}$ ) e $\mathrm{PVS}^{-1}$ (polivírus) em amostras de lodo primário. A cinética da inativação desses patógenos foi avaliada nas temperaturas $51,1^{\circ} \mathrm{C}, 53,31^{\circ} \mathrm{C}$, e $55,51^{\circ} \mathrm{C}$. As amostras foram coletadas no tempo $0 ; 0,5 \mathrm{~h} ; 1 \mathrm{~h} ; 1,5 \mathrm{~h} ; 2 \mathrm{~h} ; 4$ ou $12 \mathrm{~h} ; 8$ ou $16 \mathrm{~h}$, de acordo com o tempo de residência nos digestores. Os tempos de coletas foram determinados segundo estudos prévios que indicavam a rápida inativação dos patógenos nas temperaturas testadas. Para que houvesse redução $\geq 2 \log$ dos ovos, a temperatura de $55,5^{\circ} \mathrm{C}$ foi a que alcançou a maior velocidade de inativação, obtendo essa redução em 2 horas.

Mun et al. (2009) compararam a inativação de ovos de Ascaris lumbricoides no solo através da irradiação UV, ozônio e radiação micro-ondas. Em uma amostra de $25 \mathrm{~g}$ de solo, com $14 \%$ de água, inocularam aproximadamente $7 \times 10^{3}$ ovos. Expuseram a amostra a radiação de micro-ondas $(700 \mathrm{~W}, 2.450 \mathrm{MHz})$, por períodos que variaram de zero a 70 s. Verificaram que houve inativação de aproximadamente 2,5 log de ovos em 60 segundos. A amostra de solo, com igual concentração de ovos, quando submetida à irradiação UV de 
253,7 $\mathrm{nm}$ (intensidade de $3 \mathrm{~mW} \mathrm{~cm}$ ), com e sem agitação por 3.600 segundos, atingiu inativação de aproximadamente 0,32 e 0,01 log, respectivamente. O tratamento por ozônio obteve inativação de 0,13 log quando a amostra foi submetida, por 30 minutos, a uma dose 5,8 $\pm 0,7 \mathrm{mgL}^{-1}$ de ozônio dissolvido. Os autores esclarecem que a irradiação UV e o ozônio não foram tão eficientes devido às partículas do solo que protegem os ovos, assim como ao envoltório de três camadas desses ovos. A irradiação micro-ondas foi mais eficiente, pois alcançou altas temperaturas em pouco tempo.

Maya et al. (2010) avaliaram a eficiência de diferentes fatores combinados na inativação de helmintos presentes no lodo de esgoto. Para realizar o experimento, foram selecionados ovos de A. lumbricoides, A. suum, Toxocaracanis, Trichuristrichiura, H. nana e Taenia solium, por terem sido encontrados em lodo de diferentes países. Para avaliar os efeitos combinados de temperatura, umidade e tempo de exposição, 210 ovos desses helmintos (35 ovos de cada gênero) foram inoculados em amostras de lodo com umidade de 95, 90 e $80 \%$, submetidas a temperaturas que variaram de 30 a $80^{\circ} \mathrm{C}$ e tempo de exposição 30,60 , 120 e 180 minutos. Os autores observaram que nas condições de $70^{\circ} \mathrm{C}$, umidade de $80 \%$ e tempo de exposição de 120 minutos todos os ovos foram inativados. Nessas condições a temperatura decompõe a membrana vitelina que protege o ovo, deixando-o vulnerável. Para verificar a eficiência de cal associado à umidade foram adicionados $15 \%$ e $20 \%$ de cal em amostras de lodo com umidade de $90 \%$ e $80 \%$. As amostras foram estocadas por $0,5 \mathrm{~h}$ a 10 meses, em temperaturas entre $22-25^{\circ} \mathrm{C}$ e umidade $60-90 \%$. Com relação à adição de cal verificaram que adição de $20 \%$ de cal aumentou o pH a 12,5, contribuindo com a inativação dos ovos quando expostos por 4 meses em umidade de $80 \%$. Verificou-se ainda que Ascaris sp foi o helminto mais resistente, já os helmintos T.canis e T. solium, T. trichiura e H. nana foram os mais sensíveis aos tratamentos empregados.

No caso de oocistos de Cryptosporidium, em experimento realizado, verificou-se que estes são capazes de deslocamentos no solo, por várias semanas, sendo que em alguns casos permaneceram viáveis, no solo, por períodos maiores que 70 dias. A maioria dos oocistos é encontrada na camada superficial do solo - $2 \mathrm{~cm}$ e há um decréscimo conforme aumenta a profundidade. Ainda a respeito de profundidade: até $30 \mathrm{~cm}$ são recuperados alguns oocistos, mas nunca em profundidades superiores a 70cm (Pires, 2003)

Com relação às bactérias presentes no lodo de esgotos, quando estes são dispostos no solo, elas têm o seu tempo de sobrevivência reduzido pela competição e predação dos 
microrganismos do próprio solo, principalmente de protozoários de vida livre, considerados importantes predadores de coliformes. Tal afirmação foi comprovada por estudos de Andraus et al. (2001), nos quais bactérias entéricas aplicadas em solo estéril sob controle sobreviveram mais tempo do que aquelas semeadas em solo não estéril.

De acordo com estudos do próprio autor acima citado, cistos de protozoários, no solo e nas plantas, são rapidamente mortos pelos fatores ambientais, portanto considera como mínima a ameaça à saúde pública e de animais, contrariando recomendações de outros autores com relação aos riscos potenciais da aplicação de lodo ao solo.

Em resumo, os estudos demonstram grande variabilidade de resultados sobre a presença, ausência ou tempo de sobrevivência de diversos micro-organismos presentes no lodo de esgoto, tendo em vista que um grande número de fatores ambientais exerce influência nos experimentos, variando consideravelmente nas diferentes composições do solo.

Por essa razão, o conhecimento dos agentes patogênicos, da sua viabilidade e de sua sobrevivência na matriz solo-lodo é importante e deve ser perseguido. Ademais, a caracterização microbiológica e parasitológica do lodo pode nortear as medidas para condicionamento, considerando as alternativas de disposição possíveis a cada situação.

\subsubsection{Metais pesados}

O lodo de esgotos, dadas suas características, pode ser aplicado como condicionador de solo, entretanto, uma das principais limitações, que impossibilita a sua utilização em áreas agrícolas, refere-se a elevadas concentrações de metais pesados (Ferreira et al., 1999). Por esta razão, é necessário conhecer, avaliar e equacionar os riscos potenciais oferecidos por sua composição.

Muitos metais são, em determinadas quantidades, essenciais aos organismos, como é o caso do $\mathrm{Zn}, \mathrm{Mg}, \mathrm{Cu}$ e Fe, chamados micronutrientes, enquanto outros não desempenham qualquer função no metabolismo, sendo tóxicos às plantas e aos animais. $\mathrm{O} \mathrm{Pb}, \mathrm{Hg}$ e $\mathrm{Cd}$ são metais pesados que não existem naturalmente em nenhum organismo, nem desempenham funções nutricionais ou bioquímicas, sendo prejudiciais em qualquer concentração. 
Os metais pesados não podem ser destruídos e são altamente reativos, o que explica a dificuldade de encontrá-los em estado puro na natureza.

O lodo das estações de tratamento que recebem apenas efluentes domésticos contém uma pequena quantidade de metais pesados provenientes da própria natureza dos resíduos e das canalizações (Ferreira et al., 1999). Por outro lado, quando há disposição de efluentes industriais, os lodos podem conter diversos metais pesados, em concentrações bastante variadas, relacionadas aos processos produtivos (Silva et al., 2001).

O risco representado pelos metais pesados não está associado apenas à sua concentração. É amplamente reconhecido que a distribuição, a mobilidade e a biodisponibilidade no meio ambiente dependem não só de sua concentração, mas também, da forma de associação pela qual eles estão vinculados ao lodo (Filgueiras et al., 2002 apud Lasheen e Ammar, 2009). Logo, sua disponibilidade pode ser influenciada por reações de adsorção, complexação, precipitação, oxidação e redução.

Estudos têm sido realizados para verificar os mecanismos de acumulação, mobilidade e interferência de metais pesados presentes no lodo e aplicados ao solo. Na avaliação da transferência de metais pesados do solo para algumas espécies de hortaliças (cenoura, brócolis, alface, espinafre, couve, beterraba, aipo e alho poro), Korentajer (1991) relata que a taxa de transferência varia de planta para planta e, para uma mesma planta, varia de metal para metal. Os metais $\mathrm{Cd}$ e $\mathrm{Zn}$ foram os que apresentaram as maiores taxas de transferência, já o $\mathrm{Cr}$ e o $\mathrm{Pb}$, as menores taxas.

Jamali et al. (2009), testando as interferências no cultivo de quatro espécies de trigo, verificaram que a absorção dos metais foi distinta entre as espécies de trigo estudadas. Diferentemente do estudo de Korentajer (1991), os metais $\mathrm{Cr}$ e $\mathrm{Pb}$ tiveram taxas elevadas de transferência, Cd e Ni também apresentaram altas concentrações nas amostras de grãos de trigo. Resguardadas as diferenças de cada experimento, as conclusões de ambos confirmaram que os mecanismos de bioacumulação de metais variam, significativamente, de planta para planta, o que torna evidente a necessidade de maiores investigações sobre o tema.

Papadimitriou et al. (2007) realizaram experimento para a avaliação dos impactos no solo, da aplicação de lodo de esgoto estabilizado. Os resultados revelaram a ocorrência de comprometimento para as espécies vegetativas testadas, sobretudo, em termos de 
alongamento/crescimento de raiz, correlacionados aos efeitos tóxicos pela acumulação indireta de metais nas plantas. Em suas conclusões, os autores recomendam a realização de testes de toxicidade, antes da aplicação de lodo de esgoto, como um condicionador de solo.

Segundo Andreoli e Pegorini (2000), não há registro de nenhum efeito adverso sobre o ambiente como, por exemplo, poluição com metais pesados, quando foi aplicado o uso agrícola do lodo de esgoto, sob o ponto de vista de qualquer uma das diferentes regulamentações existentes. Em longo prazo, entretanto, o aumento da concentração de metais no solo, resultante da aplicação do lodo, torna-se uma preocupação justificada, pois, se não for adequadamente controlado, pode ameaçar a cadeia trófica (Nascimento et al., 2004).

Dessa forma, não obstante os benefícios do uso agrícola de lodo, o entendimento de que a utilização do lodo na agricultura envolve riscos de saúde pública parece ser corroborado pelos diversos estudos sobre o tema. A controvérsia reside na definição dos níveis de risco aceitáveis, ou seja, na investigação de padrões de qualidade e graus de tratamentos que garantam a segurança sanitária.

\subsubsection{Outros compostos potencialmente tóxicos no lodo}

Além de metais pesados, a matéria orgânica e os nutrientes essenciais para as plantas, tais como N, P, K, Ca, Mg e S, são encontrados, ainda, em suas formas metálicas livres e como óxidos, hidróxidos, carbonatos, sulfetos e complexos orgânicos. Estes compostos também podem sofrer reações químicas e biológicas no solo que alteram sua solubilidade e mobilidade e, conseqüentemente, a disponibilidade e toxicidade para as plantas (Miyazawa et al., 2001).

O movimento vertical e descendente desses contaminantes, pelo perfil dos solos agrícolas, pode significar um grande problema para a sociedade contemporânea, em decorrência da crescente utilização de resíduos urbanos na agricultura (Oliveira et al., 2001).

Esteller et al. (2009) realizaram experimento em cultura de milho, para quantificar a lixiviação de nitrato sob condições reais de campo, durante dois ciclos agrícolas. Três parcelas receberam tratamento com fertilizantes inorgânicos, três parcelas com 4,5 mg ha ${ }^{-1}$ de biossólido, em base seca, e três parcelas com as mesmas quantidade de biossólido compostado. Segundo os resultados, o maior percentual de nitrogênio lixiviado foi 
produzido quando foi utilizado adubo inorgânico $(37,4 \%$ e $24,0 \%$ de $\mathrm{N}$ lixiviado no primeiro e segundo anos, respectivamente), seguido por biossólidos compostados $(17,1 \%$ e 13,5\% de $\mathrm{N}$ lixiviado, no primeiro e segundo anos, respectivamente) e o último por biossólidos (11\% para ambos os anos). Os autores consideraram que essa diferença poderia estar relacionada com a forma em que o nitrogênio está presente nos fertilizantes, pois enquanto no adubo comercial está presente o nitrogênio inorgânico, nos biossólidos são basicamente apresentados na forma de nitrogênio orgânico.

Jonsson e Maia (2007) avaliaram o efeito adverso de amostras de lodo, oriundas das estações de tratamento de efluentes das cidades de Franca (SP) e de Barueri (SP), sobre organismos zooplanctônicos, utilizando, como indicador, o microcrustáceo de água doce, Daphnia similis. Os testes realizados demostraram que o uso dos dois lodos testados para fins agrícolas, nas taxas de aplicação agronômica recomendadas ou superiores a essas, constituiu algum risco para os sistemas aquáticos adjacentes.

Segundo Jonsson e Maia (2007), o risco estaria relacionado à aplicação do lodo em regiões agrícolas próximas de compartimentos aquáticos, cujos efeitos se manifestariam, a curto ou longo prazo, para organismos zooplanctônicos e, consequentemente, para outros organismos da cadeia alimentar. Esse fenômeno estaria associado ao transporte do lodo para os referidos compartimentos, assim como de seus constituintes orgânicos ou inorgânicos com ação tóxica. Uma das conclusões mais interessantes da pesquisa foi de que os efeitos tóxicos do lodo da ETE Barueri não deveriam ser atribuídos somente à presença de metais pesados já constatados nesse material, mas à presença de compostos orgânicos passíveis de serem extraídos pela acetona e que podem ter propriedades acumulativas.

A preocupação com compostos orgânicos perigosos está associada ao potencial de carcinogenicidade, mutagenicidade, teratogenicidade e risco substancial à saúde humana. Sua investigação em sistemas de esgotamento sanitário é relativamente recente, as metodologias de análises ainda não estão plenamente estabelecidas. Estas metodologias têm sido desenvolvidas e padronizadas para identificação qualitativa e quantitativa dos compostos orgânicos perigosos, subsidiando estudos de suas propriedades, bem como de métodos de remoção (Cesário Silva et al, 2001). 
Os poluentes mais comuns nos efluentes industriais são: cianeto, fenol, cloreto de metileno, tolueno, etil benzeno, tricloroetileno, clorofórmio, naftaleno, acroleina, xileno, cresós, acetofenoma, anilina, acetato de etila, entre outros (Cesário Silva et al, 2001).

São escassos os dados sobre comportamento desses poluentes dentro das ETEs, bem como das suas características físicas, químicas e bioquímicas. Pesquisas para identificação e remoção destes compostos, bem como o desenvolvimento de modelos de previsão para a tratabilidade e destino durante as operações de tratamento são de extrema necessidade.

Devido à aplicação de lodo ao solo, alguns compostos presentes nas ETEs passaram a receber atenção, entre eles estão os ésteres ftalatos (dietil, dibutil), tolueno, fenol, naftaleno, metanos clorados, etanos, benzenos, acrilonitrila e hidroquinona. A concentração desses compostos no lodo pode aumentar dramaticamente, caso haja uma contribuição industrial específica (Cesário et al., 2001).

Além desses, os denominados micropoluentes emergentes, que compreendem uma gama de substâncias presentes em medicamentos, desinfetantes, meios de contraste, detergentes, surfactantes, pesticidas, corantes, tintas, conservantes, aditivos alimentares e produtos para cuidados pessoais, podem ser encontrados em esgotos, corpos receptores, sedimentos, lodo biológico e mesmo em águas de abastecimento. Tais substâncias podem causar diferentes impactos no meio ambiente e representam um risco de saúde pública, por exemplo, causando desregulação endócrina. Na Tabela 3.5 apresenta-se alguns dos compostos e suas classes, presentes em medicamentos, que podem ser encontrados nas referidas matrizes ambientais. 
Tabela 3.5 - Grupo/Classe de alguns compostos micropoluentes emergentes.

\begin{tabular}{|c|c|c|}
\hline \multicolumn{2}{|c|}{ Grupo/classe de compostos } & \multirow{2}{*}{$\begin{array}{l}\text { Compostos } \\
\text { Trimetroprima, } \quad \text { eritromicina, } \\
\text { sulfametoxazol, cloranfenicol, amoxilina }\end{array}$} \\
\hline Fármacos & $\begin{array}{l}\text { Antibióticos humanos e } \\
\text { Veterinários }\end{array}$ & \\
\hline & $\begin{array}{l}\text { Analgésicos e anti- } \\
\text { inflamatórios }\end{array}$ & $\begin{array}{l}\text { ibuprofeno, diclofenaco, fenoprofeno, acetaminofeno, } \\
\text { naproxeno, ácido acetilsalicílico, fluoxetina, } \\
\text { cetoprofeno, indometacina, paracetamol }\end{array}$ \\
\hline & Drogas psiquiátricas & diazepam, carbamazepina, primidona, salbutamol \\
\hline & Reguladores lipídicos & $\begin{array}{l}\text { ácido clofíbrico, bezafibrato, ácido fenofibrico, } \\
\text { etofibrato, gemfibrozil }\end{array}$ \\
\hline & Beta-bloqueadores & metoprolol, propranolol, timolol, sotalol, atenolol \\
\hline & Contrastes Raio-X & iopromida, iopamidol, diatrizoato \\
\hline \multirow{4}{*}{$\begin{array}{l}\text { Produtos de } \\
\text { cuidado pessoal }\end{array}$} & Fragrâncias & nitro, perfurmes policíclico e macrocíclico, ftalatos \\
\hline & Bronzeadores & benzofenona, cânfora, metilbenzilideno \\
\hline & Repelentes de insetos & $\mathrm{N}, \mathrm{N}$-dietiltoluamida \\
\hline & Antisépticos & triclosan, clorofeno \\
\hline \multirow[t]{3}{*}{ Desreguladores } & $\begin{array}{l}\text { Produtos } \\
\text { Industriais }\end{array}$ & $\begin{array}{l}\text { alquifenóis, ftalatos, bisfenol-A, estireno, retardantes de } \\
\text { chama bromados (PBDEs), surfactantes (perfluoroctano } \\
\text { sulfonatos - PFOS) }\end{array}$ \\
\hline & Hormônios e esteróides & estradiol, estrona, estriol, dietilestilbestrol \\
\hline & Pesticidas & $\begin{array}{l}\text { PCF (pentaclorofenol), rifuralin, atrazina, DBCP } \\
\text { (dibromocloropropano), lindano }\end{array}$ \\
\hline
\end{tabular}

Fonte: Rodrigues (2007).

No caso dos medicamentos o caminho mais óbvio para a contaminação do meio ambiente é por meio da excreção na urina e fezes. Na forma inalterada, por meio de esgotos sanitários, assim como esgotos industriais ou laboratoriais, embora também outros mecanismos devam ser assumidos (Santos, 2010), tais como: descarte de compostos de diagnósticos, como meios de contraste de raios-X; eliminação de medicamentos não utilizados (vencidos ou indesejados) descartados nos domicílios junto aos esgotos domésticos; produtos farmacêuticos empregados na aquicultura, que são diretamente depositados em águas superficiais e a disposição de lodos biológicos gerados nas estações de tratamento de esgotos, frequentemente usados como fertilizantes na agricultura, conforme apresentado na Figura 3.3 


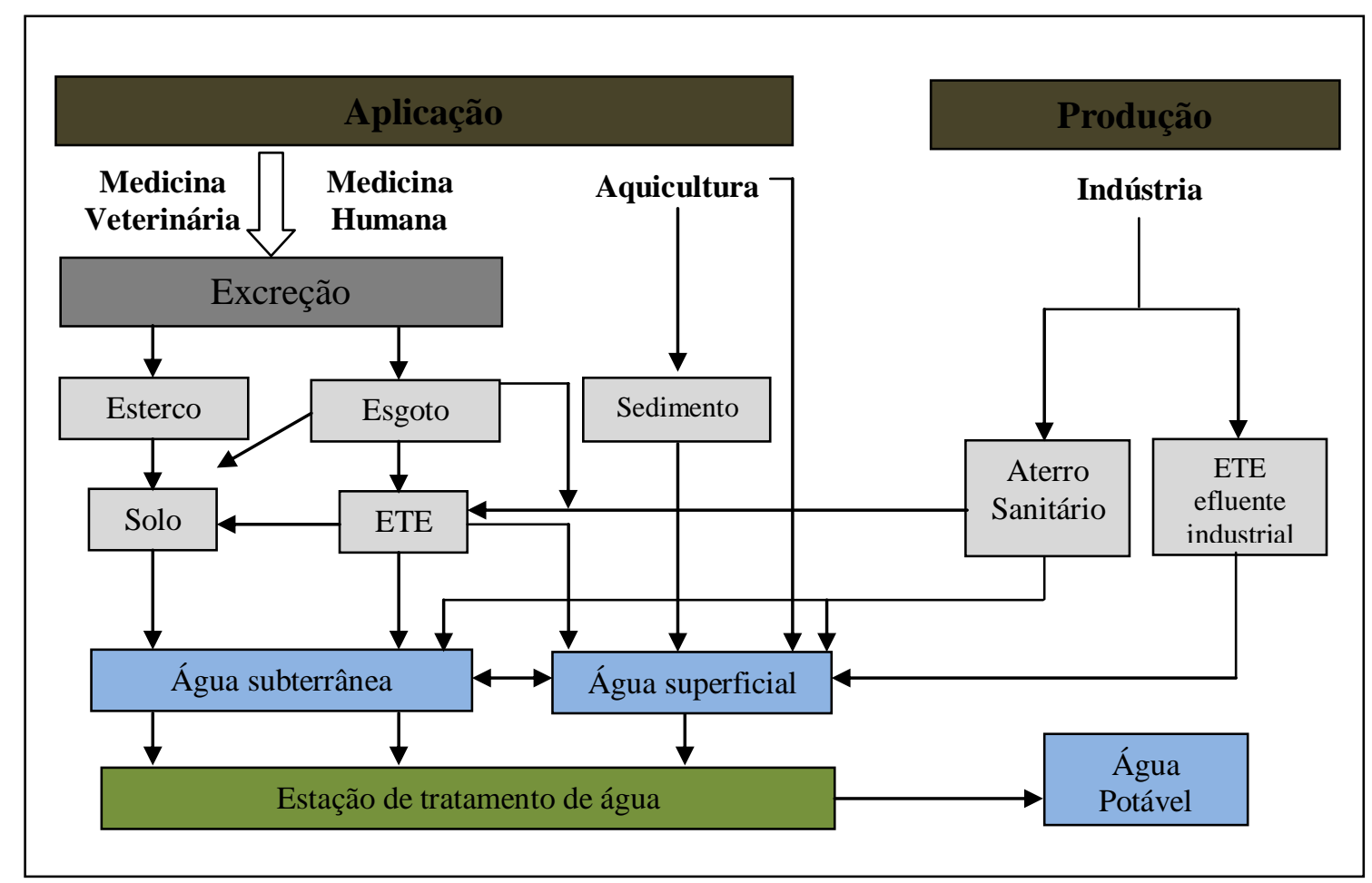

Figura 3.3 - Rotas de exposição de fármacos no ambiente.

Fonte: adaptado de Bila e Dezotti (2003).

No tratamento de esgotos a degradação biológica e transformações dos micropoluentes emergentes podem ocorrer por oxidação biológica aeróbia como no tratamento por lodos ativados, filtros biológicos, lagoas aeradas etc., ou anaerobiamente como, por exemplo, em reatores anaeróbios ou digestores de lodo, a partir da atuação de enzimas intra e extracelulares dos microrganismos (Birket e Lester, 2003).

No Brasil, estudos de avaliação de micropoluentes emergentes em matrizes ambientais como esgotos sanitários e hospitalares e em corpos de água, ainda são bastante incipientes e necessitam ser investigados, assim como os mecanismos de acumulação no lodo requerem maiores pesquisas.

A Resolução $\mathrm{N}^{0}$ 375/2006 - CONAMA estabelece que a caracterização do lodo de esgoto ou produto derivado a ser aplicado na agricultura deve incluir a determinação de substâncias orgânicas no lodo de esgoto, ou produto derivado, e no solo. São elas: benzenos clorados; ésteres de ftalatos; fenóis não clorados; fenóis clorados; hidrocarbonetos aromáticos policíclicos e poluentes orgânicos persistentes (POPs). No entanto, em função das características específicas da bacia de esgotamento sanitário e dos efluentes recebidos, as unidades gerenciadoras de lodo (UGLs) poderão requerer dispensa ou alteração da lista de substâncias orgânicas a serem analisadas. 


\subsection{MANEJO DE LODOS DE ETES - Técnicas de processamento e controle}

Como um resíduo do processo de tratamento de esgotos, o lodo de ETEs destaca-se pelo grande volume gerado e pela complexidade de gerenciamento, que, normalmente, envolve diversas etapas de processamento. Segundo estudos, o lodo representa de 1 a $2 \%$ do volume de esgoto tratado, no entanto, os custos de seu processamento e disposição final podem representar até $60 \%$ dos custos de operação e $90 \%$ dos problemas operacionais de uma ETE (Andreoli et al., 1999). Contudo, em função dos riscos inerentes, para a saúde humana e para o meio ambiente, de sua má destinação e disposição final, é preciso critério e cautela na escolha dos processos a serem adotados, nestas etapas do tratamento. O custo é um fator importante, mas há que se cuidar para que, buscando reduzir o custo de disposição, não se incorra em maiores custos sociais e ambientais.

O tipo de tratamento de esgotos utilizado influencia na quantidade gerada e em algumas características importantes do ponto de vista do gerenciamento do lodo, tais como:

- produção: quanto maior a eficiência dos sistemas de tratamento, maior a qualidade do efluente e maior a produção de lodo;

- estabilidade: potencial de geração de odor e atração de vetores;

- desidratabilidade: facilidade de desaguamento;

- composição: principalmente em relação à concentração de matéria orgânica $(\mathrm{N}, \mathrm{P}$, patógenos) e metais pesados.

As soluções técnicas e organizacionais podem ser variadas, dependendo das condições específicas locais da estação de tratamento (Kroiss e Zessner, 2007).

\subsubsection{Processos de tratamento de lodos}

A gestão do lodo produzido por uma estação de tratamento de esgotos é um dos maiores desafios para o sucesso técnico e operacional de um sistema. Portanto, é necessário que a metodologia de manejo dos lodos, em um determinado sistema, seja definida ainda na fase de projeto da estação e que seus objetivos sejam fixados de acordo com o destino final previsto para o lodo.

Os processos de tratamento de lodo visam reduzir o teor de material orgânico biodegradável, a concentração de organismos patogênicos e o teor de água para que se 
obtenha um material sólido e estável, que não constitua perigo para a saúde e possa ser manipulado e transportado com facilidade e a baixo custo (van Haandel e Além Sobrinho, 2006).

As fases de adensamento (quando necessário), estabilização e desidratação devem ser compatíveis entre si e coerentes com o destino final a ser dado ao lodo. Se o destino do lodo for o uso agrícola, a concentração de patógenos e seu potencial de geração de odores são de extrema importância.

\subsubsection{Estabilização de lodos}

Segundo Fernandes (2000), quanto mais o lodo assemelhar-se à matéria orgânica "fresca", maior será seu potencial de putrefação, de produção de odores desagradáveis, como também maior será a concentração de microrganismos patogênicos. À medida que o lodo passa por processos de estabilização, seus componentes orgânicos mais facilmente biodegradáveis são transformados e o lodo passa a ter características de lodo "estabilizado", apresentando odor menos ofensivo e uma menor concentração de microrganismos patogênicos.

A estabilização de lodos, segundo o processo empregado, pode ser dividida em:

- estabilização biológica: utilizando bactérias específicas para a estabilização da fração biodegradável da matérias orgânica, por processos de digestão anaeróbia e aeróbia;

- estabilização química: oxidação química da matéria orgânica por meio da adição de produtos químicos. O tratamento químico mais utilizado é via alcalina, em que uma base, normalmente a cal, é misturada ao lodo, elevando o $\mathrm{pH}$ e destruindo a maior parte dos microrganismos;

- estabilização térmica: obtida a partir da ação do calor sobre a fração volátil em recipientes hermeticamente fechados.

Dentre os processos biológicos de estabilização de lodo estão inseridos: digestão anaeróbia, digestão aeróbia e compostagem, este último também tem sido empregado para a higienização do lodo. 
van Haandel e Sobrinho (2006) destacam a digestão anaeróbia como processo fermentativo de maior interesse para o tratamento de lodos, podendo ser considerada como a última fermentação, visto que seus produtos, dióxido de carbono e metano, não são mais suscetíveis a outras fermentações.

Segundo Fernandes e Souza (2001), em termos genéricos, uma amostra de $100 \mathrm{~kg}$ de lodo bruto, contendo $70 \mathrm{~kg}$ de sólidos voláteis e $30 \mathrm{~kg}$ de sólidos fixos, após a digestão anaeróbia, será transformada em $40 \mathrm{~kg}$ de gases, $30 \mathrm{~kg}$ de sólidos voláteis e $30 \mathrm{~kg}$ de sólidos fixos.

Caso os digestores anaeróbios sejam operados em condições adequadas, pode haver uma redução de duas ordens de magnitude de coliformes fecais. Os ovos de helmintos, no entanto, são mais resistentes ao processo. Por esta razão, a digestão anaeróbia é um processo de estabilização eficiente para diminuir o problema do mau odor, porém a redução de patógenos é pequena, impondo limites à sua utilização (Fernandes e Souza, 2001)

Zabranská et al. (2000), em um estudo comparativo entre os processos mesofílico e termofílico, destacaram que a digestão termofílica pode conduzir a uma maior redução de sólidos, além de incrementar a produção de biogás; melhorar a eficiência na destruição de patógenos e elevar o balanço de energia, na estação de tratamento como um todo, a partir do aproveitamento energético do biogás. Citaram ainda que não foram identificados problemas com odor.

Dohányos et al. (2004), em seus estudos para o aperfeiçoamento da digestão anaeróbia verificaram que o pré-tratamento do lodo, a otimização das condições de processo e o aumento da temperatura são, frequentemente, utilizados como métodos para se completar a digestão, destacando a importância da continuidade dos estudos.

O entendimento no tocante à melhoria de tecnologias de estabilização e o seu reflexo na etapa de desaguamento do lodo, sugerindo maximização de suas qualidades de tal maneira a aprimorar as condições econômicas e ecológicas do seu manejo, são corroboradas por diversos autores (Dohanyos et al. , 2004; Jordão e Pessoa, 2005).

A digestão aeróbia também é um processo de oxidação bioquímica dos sólidos biodegradáveis contidos nos esgotos, com abundância de oxigênio dissolvido em toda a massa líquida, 
favorecendo a atividade de bactérias aeróbias e a formação de subprodutos, tais como matéria orgânica estabilizada (lodo digerido), gás carbônico e água (Jordão e Pessôa, 2005). Normalmente, ela é utilizada em estações de pequeno porte, tendo como desvantagem em relação à digestão anaeróbia o alto custo operacional de energia necessária para a aeração.

A estabilização, por processo de compostagem ocorre em meio sólido e é definida como uma "bioxidação aeróbia exotérmica de substrato orgânico heterogêneo", resultando em um processo bioquímico altamente complexo. Devido a suas propriedades de higienização, será tratada mais adiante.

\subsubsection{Remoção da umidade}

Os processos de tratamento da fase líquida dão origem a um material com elevado teor de umidade. Nestas condições, toda e qualquer operação subsequente, relativa ao manejo do lodo, deve considerar a remoção de umidade como uma medida imprescindível, visto que tanto volume quanto teor de sólidos serão fatores determinantes nos custos operacionais e na seleção das alternativas de disposição final.

Dessa forma, a escolha do melhor método de remoção de umidade deverá estar adequado às implicações da alternativa de disposição adotada, levando em conta as características do lodo, as tecnologias disponíveis, as características do local de estocagem, quando for o caso, o aumento dos custos operacionais e de transporte.

A redução do teor de água é efetuada por processos físicos (adensamento, filtração, flotação, evaporação), eventualmente precedidos por processos preparatórios de condicionamento, que visam facilitar e/ou acelerar o processo de separação de água (van Haandel e Além Sobrinho, 2006).

Serão apresentados, nesta seção, os principais processos de tratamento de lodo que visam à remoção de umidade.

\section{Adensamento}

Na maioria dos sistemas, é interessante que o lodo, antes de ser encaminhado para digestão ou desidratação, passe pelo sistema de adensamento, que consiste no aumento da concentração de sólidos, nele contidos. É mais usado nos processos de tratamento 
primário, lodos ativados e filtros anaeróbios percoladores, tendo importantes implicações no dimensionamento e na operação de digestores (Gonçalves et al., 2001)

Os principais processos de adensamento incluem:

- adensadores por gravidade - são freqüentemente utilizados para adensamento de lodos primários (faixa de 4 a 10\%), mistos (lodo primário e lodos ativado - 2 a 6\%; lodo primário e lodo de reator anaeróbio com biofilme - 4 a $8 \%$ ).

- adensadores por flotação - são usualmente empregados para o adensamento do lodo ativado em excesso, aumentando a concentração de sólidos para a faixa de 3 6\% (Jordão e Pessoa, 2005);

- adensamento por processos mecânicos - utiliza equipamentos como centrífugas, adensadores de esteira e tambores rotativos. A opção por um desses tipos deve considerar a complexidade operacional, bem como os custos de operação e manutenção de tais equipamentos.

Chao (2001) pesquisou o desempenho dos adensadores de lodo por gravidade da ETE Barueri, em São Paulo, e elaborou um diagnóstico com estratégias de otimização para essas unidades. Verificando a ocorrência de baixa concentração de sólidos no lodo adensado, a autora avaliou as unidades envolvidas, constatando que os decantadores primários eram alimentados de forma contínua, por meio de bombeamento do lodo, provocando impactos de revolvimento do lodo nos poços. Observou, ainda, o retorno de lodo excedente para os adensadores devido aos altos tempos de retenção de lodo nos mesmos, causados, principalmente, pela operação de um número excessivo dessas unidades. Visando à melhoria operacional, a autora propôs a adoção de procedimentos operacionais, tais como diminuição da taxa de aplicação superficial nos decantadores primários, promovendo melhorias na sedimentabilidade, e a diminuição do provável arraste de sólidos para o efluente, pela baixa ocorrência de curtos-circuitos. Segundo a autora, o regime de bombeamento do lodo primário foi alterado, obtendo uma melhor concentração de sólidos. Para melhorias no adensamento foi necessário diminuir o tempo de detenção na unidade, elevando as taxas de aplicação. 


\section{Condicionamento}

Esta etapa tem por objetivo principal a preparação do lodo para a fase seguinte, a desidratação, melhorando a capacidade de captura de sólidos do sistema de desaguamento. Para isto, procura-se obter uma modificação do tamanho, da superfície específica, da distribuição e da interação das partículas de lodo, promovendo a formação de agregados maiores (flocos), por meio dos processos de coagulação e floculação.

O condicionamento pode ser realizado através da utilização de produtos químicos inorgânicos, de produtos químicos orgânicos ou de tratamento térmico (Gonçalves et al., 2001).

O condicionamento químico inorgânico aumenta, consideravelmente, a massa de lodo a ser gerenciada na estação, pois as quantidades adicionadas de coagulantes são relativamente grandes e tornam-se parte das tortas de lodo produzidas. O condicionamento químico contribui para a redução do potencial de queima na incineração (Gonçalves et al., 2001).

Outros materiais poderiam ser utilizados como condicionadores, tais como resíduos de alto forno da indústria de cimento e de cal, ricos em cálcio e potássio, porém, para obter-se a mesma elevação de $\mathrm{pH}$ que a cal propicia, seria necessária a adição de uma quantidade duas vezes maior que a da cal. Cinzas de incineradores e carvão pulverizado também poderiam reduzir o consumo de cloreto férrico e cal (Gonçalves et al., 2001).

\section{Desidratação}

O processo de desidratação ou desaguamento tem por objetivo reduzir o volume do lodo, produzindo um material com comportamento mecânico próximo ao dos sólidos. Para isto, podem ser adotados processos naturais ou mecânicos. Os meios naturais usam a evaporação e a percolação como principais mecanismos de remoção de água, já os processos mecanizados baseiam-se em mecanismos como a filtração, a compactação ou a centrifugação, para acelerar o desaguamento.

Os principais processos utilizados para diminuição do teor de umidade são os seguintes:

- processos mecânicos: centrífugas, filtros prensa, filtros a vácuo e prensas desaguadoras. No caso dos filtros a vácuo, os meios filtrantes devem ser 
selecionados de acordo com as características do lodo a ser filtrado. O melhor desempenho é conseguido com lodos com teor de ST em torno de 8 a 10\%;

- processos naturais: lagoas de lodo e leitos de secagem.

Os métodos mais comuns de secagem natural são: leitos de secagem e lagoas de secagem de lodo. Os leitos funcionam, em essência, como filtros granulares de bateladas de lodo (Pedroza et al., 2003, apud Pegorini e Andreoli, 2006). A remoção da água por percolação é muito maior que a da evaporação, mas a evaporação é necessária para que se produza um lodo de alto teor de sólidos (van Haandel e Além Sobrinho, 2006).

No desaguamento mecânico a remoção de água é parcial, obtendo-se um produto final com um teor de sólidos entre 15 e $35 \%$, dependendo das características do lodo e das condições operacionais. A torta produzida apresenta inconvenientes para sua disposição final, não somente por sua constituição semi-sólida, mas também por causa da presença de patógenos.

\subsubsection{Higienização de lodo de esgoto}

No tratamento de águas residuárias, durante o processo de sedimentação, grande parte dos organismos existentes, no esgoto, coprecipita junto com as partículas orgânicas, concentrando-se no lodo (Ilhenfeld et al., 1999). Para o lodo, o nível de redução de patogenicidade é definido em função das exigências estabelecidas para cada destino a ser dado ao lodo. O lodo, ao ser disposto no solo, não deve causar danos à saúde da população, nem impactos negativos ao meio ambiente.

Dessa forma, para se promover o destino sanitário adequado e a utilização dos lodos de esgoto, é necessário que ele passe por um processo complementar de estabilização, denominado higienização. Este processo visa eliminar ou reduzir significativamente a densidade de microorganismos, tornando o produto final biologicamente seguro para as diferentes aplicações desejadas (Passamani et al., 2002).

De acordo com a Environmental Protection Agency - EPA (1992), o grau de higienização do lodo:

- é muito importante para a sua utilização na agricultura; 
- é moderadamente importante para a disposição em aterro sanitário e transporte em geral;

- é sem importância quando o destino final é a incineração ou disposição oceânica. Ressalta-se que essas práticas não são utilizadas no Brasil e, em função de acordos com a Comunidade Europeia e a Convenção de Estocolmo (2001), estão sendo abolidas em grande parte dos países.

Além de reduzir a densidade de patógenos, a higienização do lodo visa eliminar os maus odores e inibir, reduzir ou eliminar o potencial de putrefação (Miki et al., 2006).

Dentre os métodos para a higienização, destacam-se, pela sua facilidade operacional e baixos custos operacionais, a compostagem e a calagem. $\mathrm{O}$ tratamento térmico vem sendo viabilizado através do uso de biogás produzido em estações de tratamento de esgotos anaeróbias, nesse caso o tratamento é feito a temperaturas máximas em torno de $150^{\circ} \mathrm{C}$.

\section{Compostagem:}

A compostagem é um método de estabilização e desinfecção eficiente e permite $o$ processamento com outros resíduos orgânicos. Pode ser realizada com tecnologias de baixo custo e seu produto final é de alta qualidade agronômica (Andreoli e Fernandes, 1999). A compostagem é um processo biológico no qual microrganismos, geralmente em mistura com resíduos orgânicos, em processos exotérmicos de degradação do material orgânico, geram calor e mantém a temperatura entre 55 e $65^{\circ} \mathrm{C}$, por alguns dias.

Nessas condições, os organismos patogênicos do lodo são inviabilizados, tornando seus percentuais de presença no lodo apropriados para a utilização na agricultura (Pegorini, 2002). O material resultante é chamado de composto e é rico em nutrientes. O alcance da inativação térmica dos patógenos depende do tempo de exposição a uma dada temperatura.

Além do controle de patogênicos, a estabilização por meio da compostagem de lodo é um meio eficaz para reduzir os efeitos negativos da matéria orgânica instável no solo (Bernal et al., 1998, apud Sanchez-Monedero et al., 2004)

Segundo Andreoli et al. (2006), a garantia de uniformidade do composto produzido é, ainda, um desafio a ser vencido, pois, geralmente, os tipos de nutrientes nele contidos, a 
estrutura e os sais totais variam de lote para lote, dificultando a garantia nutricional de todos os lotes.

Ademais os benefícios conhecidos da compostagem do lodo, alguns obstáculos ainda precisam ser vencidos. Chen (2012) em uma abordagem do problema de acúmulo de lodo nas cidades chinesas, que vem se agravando nos últimos anos, apresenta uma discussão sobre o uso da compostagem como uma alternativa viável, entretanto, aponta como desafios:

- a aceitabilidade da sociedade ao uso dessa tecnologia, visto a dissipação de odores com o uso do composto;

- a perda de nitrogênio no processo de compostagem, que pode comprometer o interesse agronômico do composto;

- a imobilização de metais pesados e a redução dos efeitos dos poluentes na taxa de degradação biológica.

Essas questões requerem investigação e o avanço no desenvolvimento de tecnologias que se contraponham aos problemas mencionados.

A compostagem de lodo, em leiras aeradas, segundo estudos de Szabová et al (2010) demostrou-se eficiente na inativação de A. suum. Os autores agregaram ao lodo resíduos agrícolas e de produção de cerveja. No interior da pilha $(1,5 \mathrm{~m})$ foram inoculados dois mil ovos de A suum na porção inicial, intermediária e final da leira. Os parâmetros avaliados foram: $\mathrm{pH}$, sólidos totais, matéria orgânica e inorgânica, nitrogênio e fósforo total, temperatura e relação C:N. As temperaturas máximas alcançadas durante o processo foram de $65^{\circ} \mathrm{C}$ no inverno e de $71^{\circ} \mathrm{C}$ no verão, caracterizando a fase termofílica. Dentro dessa fase a inativação total dos ovos ocorreu no $6^{\circ}$ dia. Notou-se que fatores como $\mathrm{pH}$, concentração de nutrientes e amônia também desempenharam papel na inativação. Os autores concluíram que a compostagem é um tratamento eficiente na redução de helmintos, gerando um composto que pode ser aplicado na agricultura.

A EPA (1992, apud Andreoli et al., 2006), reconhece a compostagem como um processo de avançada redução de patógenos, quando ao utilizar o método de leiras estáticas aeradas sua temperatura permanece superior a $55^{\circ} \mathrm{C}$ por, pelo menos, 13 dias. Este lodo pode ser aplicado em solo, para uso agrícola, (incluindo gramados e jardins) e também em 
substratos. Esta aplicação pode ser feita desde que não ocorra presença de metais pesados e elementos outros que possam poluir o solo e a contaminar a biota que tiver contato com ele

Os parâmetros biológicos a serem monitorados devem ser ovos de helmintos viáveis, coliformes fecais, Salmonella spp. Isso, quando em uso ou estocado, assegurando que não ocorra renascimento. Estudos comparativos, entre sistemas de leiras revolvidas e de leiras estáticas aeradas, mostraram que a segunda alternativa é mais eficaz na eliminação de patógenos (Andreoli et al., 2006).

Segundo Andreoli et al. (2006), a compostagem é uma alternativa que só pode ser analisada como solução centralizada, pois instalar e operar pequenos sistemas, além do custo elevado, torna-se muito complicado do ponto de vista operacional, já que este processo depende de um resíduo estruturante externo.

\section{Caleação:}

O tratamento com a cal é eficaz, de baixo custo e pode ser implantado com tecnologia simples. É um método de estabilização e desinfecção que consiste na mistura da cal virgem $(\mathrm{CaO})$ ao lodo em proporções que variam de $30 \%$ a 50\%, em função do peso seco do lodo. Os fatores que intervêm no processo de desinfecção são a alteração da temperatura, a mudança do pH e a ação da amônia resultante de reações ocasionadas pelo aumento de temperatura e do pH. Com isto, tem-se a inativação ou destruição da maior parte dos patógenos e, principalmente, a redução considerável do odor do lodo (Andreoli e Fernandes, 1999)

Em trabalhos realizados pelo PROSAB/SANEPAR, verificou-se que uma umidade entre 65 e $75 \%$ melhora a eficiência da caleação dos lodos. Esta faixa de umidade permitiria uma melhora na reação da cal com a água contida no lodo, favorecendo uma boa reação exotérmica e uma boa plasticidade, o que é fundamental para uma boa mistura do lodo com a cal e valores de pH mais homogêneos (Ilhenfeld et al., 1999).

Segundo Passamani (2000), a calagem é um dos processos mais eficientes para a eliminação dos patógenos no lodo, além de atuar na estabilização e na desodorização do mesmo. Neste experimento foram testadas diferentes dosagens de calagem. Nas análises de viabilidade de ovos de helmintos não foram detectados ovos nos resultados dos experimentos, submetidos a 24 horas em contato com a cal, nas dosagens de 30, 40, 50 e 
$60 \%$. Entretanto, nas menores dosagens (10 e 20\%) foram encontrados 0,33 ovos/gMS e 0,44 ovos/g M), sendo que 53\% destes ovos eram viáveis.

\section{Tratamento Térmico:}

A higienização do lodo a partir de tratamento térmico apresenta resultados satisfatórios. Sua eficácia depende do conhecimento dos parâmetros que influem diretamente no processo de inativação e/ou destruição dos organismos patogênicos, quais sejam: temperatura e tempo de exposição.

O tratamento térmico pode ser utilizado em diferentes tipos de lodo, sendo recomendável um teor de sólidos na alimentação entre 15 e 30\% (Gonçalves et al., 2001).

Por meio de investigação experimental, Pedroza et al. (2006) determinaram as curvas de sobrevivência térmica de bactérias patogênicas, a partir das quais é possível definir os tempos de decaimento decimal (D), que representa o tempo necessário para que ocorra a destruição de $90 \%$ desta população (uma escala logarítmica). O conhecimento da curva de sobrevivência térmica de organismos indicadores de qualidade sanitária possibilita estimar a relação adequada entre o tempo de exposição do lodo e determinadas temperaturas, suficientes para alcançar a higienização.

Outro ponto relevante a ser considerado é a distribuição de calor no lodo, pois não ocorre de forma homogênea, estando diretamente relacionada com as propriedades físicas e da umidade do material. Desta forma, o tempo de exposição adequado, provavelmente, será bem maior na prática (Pedroza et al., 2006). A EPA (1992, apud Pedroza et al., 2006), recomenda que haja controle de temperatura, de maneira que se garanta uma temperatura de $70^{\circ} \mathrm{C}$ durante um período mínimo de 60 minutos.

\section{IV - Solarização}

A solarização é um processo no qual o lodo de esgoto é submetido à secagem, aproveitando as condições climáticas de alta insolação e temperatura ambiente. De forma a potencializar os efeitos da insolação, normalmente usa-se uma cobertura plástica transparente, de espessura reduzida $(30-50 \mathrm{~mm})$, criando o efeito estufa. Os raios ultravioletas atuam na superfície, enquanto, no interior, predomina a oscilação periódica de 
temperatura durante o tratamento, criando alterações nas condições químicas, físicas e biológicas do meio. Desse modo, com a diminuição da umidade (sem a interferência de chuvas) e o efeito estufa proporcionado pelo plástico transparente, o processo de higienização é acelerado e promove a redução na concentração de microrganismos patogênicos (Ghini, 1997 apud Argel, 2010).

A técnica de solarização é considerada uma solução simples, de fácil aplicação, além de não requerer alto investimento financeiro, com a vantagem de não gerar outros resíduos no processo. O filme plástico transparente permite a passagem da radiação solar e sua conversão, em energia calorífica, gera vapores que podem alcançar $50^{\circ} \mathrm{C}$, a essa temperatura muitos patógenos do lodo podem ser inativados, como bactérias, fungos, vírus e nematoides (Silva, 2007).

No Paraná, pesquisa realizada por Ferreira (2001), avaliou o efeito da solarização como processo para redução de umidade e ovos de helmintos, no lodo anaeróbio digerido. No experimento avaliou-se a redução de ovos viáveis de helmintos, em um lodo disposto em leito de secagem por um período de 28 dias, com ou sem revolvimento do lodo. Os resultados mostraram reduções de 81,61 a 97,48\% na concentração de ovos viáveis, correspondendo a valores finais de 0,34 a 9,33 ovos viáveis/gms. Os teores finais de umidade variaram entre 55,82 e $77,46 \%$.

Bonnet et al. (1998) apud Argel (2010) indicaram que o uso de estufa agrícola é um meio útil de aproveitamento da radiação solar, pois atua no aquecimento do ar interno, e, segundo afirmam, promove uma redução significativa das concentrações de bactérias pela radiação solar e desidratação do lodo.

Argel (2010) realizou experimentos utilizando os tratamentos com estufa agrícola (solarização) e caleação, aplicados em três lotes de lodo gerados em reator UASB e que haviam sido dispostos em leitos de secagem - umidade inicial em torno de 70\%. No caso do tratamento com estufa agrícola, após 35 dias, em apenas um dos lotes o decréscimo de ovos viáveis de helmintos atendeu a legislação (Resolução n³75/2006- CONAMA) para lodo classe A. A presença salmonella spp não foi confirmada desde a primeira análise, antes do processo de solarização. Para coliformes termotolerantes, o menor valor

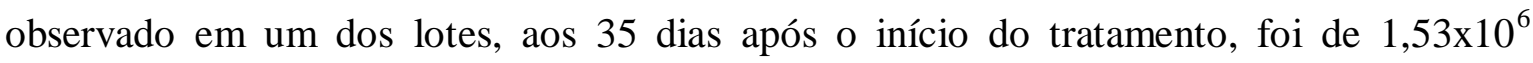
$\mathrm{NMP} / \mathrm{gST}$, sendo este um valor insuficiente para alcançar o padrão de lodo Classe A. 
São necessários estudos mais detalhados sobre a solarização, de maneira a conceber um sistema que garanta segurança e eficiência, visto que há muitas lacunas a serem preenchidas sobre os parâmetros de controle na utilização da energia solar, com relação ao ar, temperatura e umidade (Bennamoun, 2012).

\subsubsection{Controle}

A contínua busca por menores impactos ambientais, também, é resultante de exigências impostas por requisitos legais. As legislações ambientais tornaram-se mais restritivas na última década, exigindo, das empresas, um comportamento ambiental mais ativo, responsabilizando-as pela completa gestão do ciclo de vida dos seus produtos, diminuindo assim os impactos ambientais, não apenas dos processos, mas também daqueles causados pelas atividades de descarte (Oliveira et al., 2003).

Para a correta expressão das características dos lodos e a uniformidade na linguagem, são apresentados, a seguir, os indicadores de controle mais usuais e suas relações (von Sperling e Gonçalves, 2001; Metcalf \&Eddy, 1991):

- relação entre teor de sólidos e umidade - a umidade influi nas propriedades mecânicas do lodo e, estas por sua vez, influenciam no seu manuseio e disposição final, bem como no seu volume;

- remoção de sólidos em suspensão voláteis - SSV - o processo de digestão remove os sólidos orgânicos biodegradáveis. A eficiência desta remoção situa-se entre 40 e 55\% de SSV;

- relação SV/ST: essa relação é um bom indicador do teor de matéria orgânica presente no lodo;

- expressão do teor de sólidos totais - ST - o teor de sólidos é dado na forma de sólidos secos, em relação ao lodo (sólidos e água). Pode ser expressa em $\mathrm{mg} / \mathrm{L}, \mathrm{g} / \mathrm{m}^{3}$, ou ainda em porcentagem;

- densidade do lodo - uma vez que o lodo é composto por água (densidade igual a 1), sólidos fixos (densidade por volta de 2,5) e sólidos voláteis (densidade, aproximadamente, 1), a densidade do lodo é função da distribuição relativa destes três componentes;

- carga de sólidos - a carga de sólidos do lodo é obtida pela razão entre a massa de sólidos secos e a unidade de tempo. É, usualmente, expressa em kg/dia; 
- captura de sólidos - a captura dos sólidos é a recuperação de sólidos, que não foram separados da fase líquida, em diferentes etapas do tratamento do lodo. Sob a forma de sobrenadantes, drenados ou filtrados pelas unidades de separação das fases sólida e líquida, eles retornam ao início do processo, junto aos esgotos afluentes;

- grau de estabilização - a estabilização se refere às características gerais do lodo e, portanto, provoca definições qualitativas e descritivas. Existem vários indicadores que podem ser utilizados para avaliar o grau de estabilização do lodo: odor, nível de redução de patógenos, toxicidade, atividade enzimática, taxa de absorção de oxigênio, teor de cinzas, viscosidade, poder calorífico, entre outros.

Valores de densidade e massa específica correntes na literatura, assim como das relações de sólidos são apresentados na Tabela 3.6.

Tabela 3.6 - Faixas usuais de densidades e de massas específicas de alguns tipos de lodo

\begin{tabular}{lcccc}
\hline \multicolumn{1}{c}{ Tipo de lodo } & $\begin{array}{c}\text { Relação } \\
\text { SV/ST }\end{array}$ & \%ST & $\begin{array}{c}\text { Densidade do } \\
\text { lodo }\end{array}$ & $\begin{array}{c}\text { Massa específica } \\
\left(\mathbf{k g} / \mathbf{m}^{3}\right)\end{array}$ \\
\hline Primário & $0,75-0,80$ & $2-6$ & $1,02-1,03$ & $1.020-1.030$ \\
\hline Secundário aeróbio & $0,75-0,80$ & $0,6-1,0$ & $1,005-1,025$ & $1.005-1.025$ \\
\hline Primário adensado & $0,75-0,80$ & $4-8$ & $1,023-1,03$ & $1.023-1.030$ \\
\hline Secundário adensado & $0,75-0,80$ & $2-7$ & $1,007-1,03$ & $1.007-1.030$ \\
\hline Misto adensado & $0,75-0,80$ & $3-8$ & $1,02-1,03$ & $1.020-1.030$ \\
\hline Misto digerido & $0,60-0,65$ & $3-6$ & 1,03 & 1.030 \\
\hline Desidratado & $0,60-0,65$ & $20-40$ & $1,05-1,08$ & $1.050-1.080$ \\
\hline
\end{tabular}

Fonte: adaptado de von Sperling e Gonçalves, 2001.

\subsubsection{Disposição adequada dos resíduos}

No Brasil, o gerenciamento adequado dos resíduos inicia-se pela sua classificação ambiental, de acordo com a norma NBR 10.004. Segundo essa norma os resíduos são classificados em: classe I - perigosos; classe II - não perigosos; classe IIA - não inertes; resíduos classe IIB - inertes.

Os resíduos perigosos são aqueles que apresentam características de inflamabilidade, corrosividade, reatividade, toxicidade e patogenicidade. Entretanto, essa mesma norma exclui, em seu item 4.2.5.1, os resíduos gerados nas estações de tratamento de esgotos domésticos como perigosos, pelo critério de patogenicidade. Para as demais características, é imprescindível o conhecimento dos contribuintes, principalmente quando a estação 
recebe em seu sistema efluentes industriais, para a partir daí se definir quais as características e substâncias devem ser pesquisadas.

Dessa forma, a escolha do método mais adequado de disposição final do lodo deve ter em conta a classificação dos resíduos, que por sua vez depende da determinação de suas características.

As alternativas mais comuns envolvem a disposição em aterros sanitários, landfarming, incineração, além das alternativas que prevêem o uso benéfico como, por exemplo, a reciclagem agrícola. Pedroza (2005) incluiu a disposição oceânica, porém cita que, segundo Tsutiya (1999), esta prática foi proibida nos Estados Unidos, desde 1992, pela Ocean Dupimg Act, e na Comunidade Européia desde 1998. A partir da assinatura e ratificação da Convenção Estocolmo 2001, o Brasil comprometeu-se a eliminar as fontes geradoras de poluentes orgânicos persistentes - POPs, entre as quais, estão os incineradores.

As alternativas mais comuns de disposição final são comentadas a seguir.

\subsubsection{Aterro Sanitário}

A implantação de um aterro sanitário requer estudos ambientais e o delineamento de controle ambiental criteriosos, pois o líquido produzido nos aterros, também chamado de lixiviado ou chorume, contém elevadas concentrações de contaminantes, entre eles os metais pesados e poluentes orgânicos. A operação de um aterro consiste, geralmente, na deposição de resíduos em trincheiras, que são compactados e recobertos com solo ou materiais inertes com controle de variáveis técnicas e ambientais.

No caso do lodo, a disposição é feita em células previamente impermeabilizadas. Em seguida à disposição, é feita a cobertura por uma camada de terra. A atividade de degradação é normalmente anaeróbia, lenta e com produção de metano, que normalmente é queimado, embora possa ser aproveitado. A instalação de um aterro sanitário possibilita a reutilização da área alocada, com restrições.

Na Europa, a proibição de lançamento de lodo no mar fez com que os países procurassem alternativas para disposição final, sendo interessante para isso uma redução dos volumes gerados, dentre elas a disposição final em aterro sanitário. Para tanto, os órgãos receptores 
(municipal, estadual ou particular) têm exigido teores de sólidos de pelo menos 35 ou até 40\% (Miki et al., 2006).

\subsubsection{Landfarming}

O landfarming é uma alternativa de tratamento e disposição final em que o substrato orgânico é degradado, biologicamente, pelos microrganismos presentes no perfil arável do solo (até $20 \mathrm{~cm}$ ). Os íons metálicos liberados, nesta degradação, são incorporados neste perfil, de forma a não haver contaminação do lençol freático.

Esta alternativa foi desenvolvida no âmbito da indústria petrolífera, apresentando bons resultados com outros resíduos orgânicos, inclusive com elevadas doses de lodo de esgotos.

As doses de lodo, aplicadas ao solo, variam de 60 a 70 t/ano em base seca, para áreas que não têm impermeabilização na camada inferior, e de 300 a 600 t/ano, quando são usados terrenos com impermeabilização da camada de solo a $60-80 \mathrm{~cm}$ de profundidade (Ferreira et al., 1999). O aporte continuado de metais pesados e compostos químicos tóxicos orgânicos e inorgânicos inviabiliza áreas de landfarming para qualquer uso futuro. Sua aplicação em grande escala dentro de critérios ambientais rígidos torna-se complexa e requer pessoal especializado (CETESB, 1999). Projetos de landfarming devem conferir proteção às águas, subterrâneas e superficiais, em relação à migração de poluentes, pormenorizados em planos específicos de operação, monitoramento, emergência e fechamento. Como para aterros sanitários, são quesitos para o landfarming a desidratação, a um teor de sólidos mínimo de $15 \%$, e estabilização prévia do material a destinar.

\subsubsection{Incineração}

Métodos térmicos de redução de volume ganharam atenção em países desenvolvidos algumas décadas atrás, na medida em que se tornavam raras as áreas adequadas ao uso de métodos mais simples e baratos de disposição. A incineração é um processo que implica na destruição das substancias orgânicas presentes no lodo através de combustão controlada de resíduos, aplicável a lodos de esgotos previamente adensados, desaguados a um teor de sólidos mínimo de $25 \%$ e macerados. O volume de cinza residual é normalmente inferior a 
4\% do volume de lodo desaguado alimentado ao incinerador (Luduvice e Fernandes, 2001).

Em sistemas com incineradores, são importantes ao processo o controle odorífero e o conhecimento da composição e poder calorífico do lodo. O processo exige também sistemas de alimentação com temperatura adequada de combustão, tempo de residência para queima e instalações auxiliares específicas para controle ou recuperação de gases, líquidos e particulados segundo os padrões estabelecidos pela legislação ambiental (Valentin, 1994 apud Andreoli, 1999). É necessária uma rotina de disposição final das cinzas em aterros sanitários. Alguns impactos ambientais negativos potencialmente causados pela incineração são: impacto visual decorrente da construção do incinerador e da fumaça produzida; contaminação de rios e aquíferos por vazamento de efluentes; poluição sonora decorrente do funcionamento do incinerador e poluição do ar por lançamento de diversos poluentes como $\mathrm{CO}, \mathrm{SO}_{2}$, compostos orgânicos complexos e particulados (Andreoli, 1999). É uma alternativa que exige vultoso investimento inicial e apresenta custo elevado de operação, requerem cuidados operacionais sofisticados.

A incineração é considerada uma das formas melhor correlacionadas com a formação de dioxinas e de furanos. Em função disto, mais de uma centena de países, entre os quais o Brasil, comprometeram-se a reduzir as fontes de geração de dioxinas e de furanos, ao assinarem a Convenção de Estocolmo, 2001. No Brasil, esta convenção foi ratificada por meio de um Decreto.

Como resultado da expansão das pesquisas na última década, o grande espectro de consequências à saúde agora creditadas às dioxinas incluem cânceres, efeitos reprodutivos e no desenvolvimento, deficiência imunológica, disrupção endócrina incluindo diabetes mellitus, níveis de testosterona e do hormônio da tiróide alterados, danos neurológicos incluindo alterações cognitivas e comportamentais em recém-nascidos de mães expostas à dioxina, danos ao fígado, elevação de lipídios no sangue, o que se constitui em fator de risco para doenças cardiovasculares e danos à pele (APHA1, 1995). 


\subsubsection{Usos benéficos do lodo}

As tendências da normalização mundial indicam os esforços para a redução da geração de resíduos e, tanto quanto possível, seu reuso ou reciclagem. As diretivas da Comunidade Européia têm introduzido uma nova definição de eficácia para as atividades de valorização e eliminação de resíduos, de modo a promover as melhores práticas ambientais. Com isso, legislam sobre as questões da disposição de resíduos com o objetivo de reduzir os impactos ambientais negativos, apresentando uma abordagem que considera o resíduo não apenas como fonte poluidora, mas também como um recurso potencial a explorar.

A constituição do lodo apresenta elementos que lhe agregam valor, possibilitando seu uso como matéria prima ou insumo de processos industriais, agrícolas, energético, etc. A concentração de NPK, por exemplo, pode exceder a 4\% do material, equivalente a 75 a 100 $\mathrm{R} \$ / \mathrm{t}$ base seca, tornando-se um atrativo se comparado com os fertilizantes químicos (Pegorini et al., 2006).

I - Uso agrícola do lodo de esgotos

O uso de lodo de esgotos em áreas agrícolas vem crescendo ao longo dos últimos anos em todo o mundo. Esse incremento tem conquistado espaço não só por aproveitar os efeitos benéficos dos componentes presentes no lodo, mas também por se tratar de uma alternativa de baixo custo quando comparada às demais. Com isso a disposição agrícola do lodo de esgotos demanda, também, maior rigor para sua aplicação. Diversos estudos têm sido conduzidos para avaliar a segurança e os benefícios advindos de sua aplicação ao solo.

O uso agrícola do lodo possibilita a recuperação de nutrientes, a promoção de melhorias físicas, especialmente na estruturação do solo, e é considerado como uma solução definitiva para a disposição do lodo, transformando um rejeito em um importante insumo agrícola.

Alguns autores ressaltam que o lodo de esgoto não pode ser considerado um fertilizante orgânico substituto da adubação convencional, mas deve ser visto como um complemento desta adubação. Entretanto, Bonnet (1998) incluiu o uso do lodo de esgoto como fertilizante e condicionador de solos, em culturas agrícolas de cereais, leguminosas, pastagens e adubação de cobertura, fruticultura, floricultura de espécies arbustivas e 
arbóreas, jardinagem, paisagismo de áreas verdes urbanas, recuperação de áreas degradadas e em silvicultura de espécies exóticas e nativas.

O aumento do risco de contaminação por metais dos cafezais fertilizados com lodo de esgotos motivaram os estudos de Tezotto et al. (2012). Os autores investigaram os efeitos do $\mathrm{Cd}, \mathrm{Zn}$ e Ni em cafeeiros adultos, aplicando doses desses metais a plantas de café com setes anos de idade. Depois de três meses, observaram uma boa penetração dos três metais no solo, especialmente nos primeiros $50 \mathrm{~cm}$, região em que se concentram as raízes dessas plantas. Os teores de $\mathrm{K}, \mathrm{Ca}, \mathrm{Mg}, \mathrm{S}, \mathrm{B}, \mathrm{Cu}, \mathrm{Fe}$ e $\mathrm{Mn}$ no solo não foram afetados. Com base nas quantidades de metais utilizados e os resultados obtidos, os pesquisadores verificaram que as plantas de café são altamente tolerantes aos três metais testados. O estado nutricional das plantas de café, em termos de teores foliares de $\mathrm{K}, \mathrm{Ca}, \mathrm{Mg}, \mathrm{S}, \mathrm{B}, \mathrm{Cu}, \mathrm{Fe}$ e $\mathrm{Mn}$, não foi afetado pela aplicação de $\mathrm{Cd}$, Ni ou $\mathrm{Zn}$. A concentração de $\mathrm{N}$ nas folhas não mudou com a aplicação de $\mathrm{Ni}$ ou $\mathrm{Zn}$; no entanto, uma diminuição foi observada com doses de 45 e 90 g Cd por planta. Em relação ao P nas folhas, a concentração diminuiu com doses de 45 e 90 g Cd e 600 g de Zn por planta. Além disso, mesmo em doses elevadas, o transporte para os grãos, parte consumida por seres humanos, foi pouco significativo.

Segundo Lemanski et al. (2006), em pesquisa realizada com o lodo de esgotos proveniente da ETE Brasília Norte (CAESB), o lodo de esgoto apresentou uma vantagem comparativa em relação ao fertilizante mineral, com evidências positivas para doses de 30 a $45 \mathrm{t} \mathrm{ha}^{-1}$. O experimento tinha por objetivo avaliar a resposta do milho à aplicação de lodo úmido (teor de água $900 \mathrm{~g} \mathrm{kg-}^{1}$ ) nas doses de 0,7,5, 15, 30 e $45 \mathrm{t} \mathrm{ha}^{-1}$ em comparação com fertilizante mineral aplicado em quantidades equivalentes de $\mathrm{N}, \mathrm{P}_{2} \mathrm{O}_{5}$ e $\mathrm{K}_{2} \mathrm{O}$. O experimento foi realizado na Embrapa Cerrados, num Latossolo Vermelho distrófico argiloso em dois cultivos. Tanto o lodo de esgoto quanto o fertilizante mineral foram aplicados apenas antes do primeiro cultivo e a produtividade avaliada no primeiro e segundo cultivos. Para as doses de 30 e $45 \mathrm{t} \mathrm{ha}^{-1}$ mencionadas, os resultados de produtividade foram superiores à média nacional da cultura de milho e evidenciaram os efeitos (imediato e residual) do lodo de esgoto como fertilizante. Segundo os autores, com as devidas ressalvas a outros fatores como os limites de metais pesados e agentes patogênicos estabelecidos pela legislação brasileira, os resultados revelam a oportunidade de aproveitamento do biossólido da CAESB como fertilizante na produção de milho no Distrito Federal. 
Pegorini (2002) afirma que, embora a valorização agrícola do lodo seja crescente no mundo todo, e em especial nos EUA e CEE, podem ser encontradas abordagens bastante distintas na avaliação de riscos da atividade na legislação mundial. No entanto, existe uma coerência significativa com relação aos fatores controlados. Os parâmetros enfatizados mundialmente têm sido (USEPA,1997; UE86/278/EEC; Bundgaard e Saaybe,1992):

- qualidade do lodo de esgoto: conteúdo de nutrientes, conteúdo de poluentes (metais pesados e compostos orgânicos), redução de patógenos;

- quantidade máxima de poluentes que pode ser aplicada nos solos;

- limitações para a área de aplicação: declividade, culturas, proximidade a corpos d'água; épocas de aplicação;

- dosagens de aplicação: baseadas na necessidade agronômica ou alterações de características do solo;

- instruções de manejo do resíduo;

- monitoramento.

Santos (2001) afirma haver uma convergência do pensamento mundial quanto às exigências por maiores níveis de qualidade para reciclagem agrícola do lodo, refletindo em normatizações mais rigorosas que resultarão em menor contaminação dos lodos produzidos. Esta tendência responde parcialmente às pressões ambientais e aos questionamentos quanto aos benefícios da aplicação do uso agrícola, representando uma maior garantia de segurança da prática.

No Brasil, as pesquisas sobre o uso agrícola do lodo já trouxeram conhecimentos significativos para esta atividade em vários estados, gerando inclusive Normas Técnicas no Paraná, São Paulo, Distrito Federal, bem como elaboração da Resolução $n^{0}$ 375/2006 CONAMA. Apesar de ser uma alternativa viável do ponto de vista econômico e ambiental, o uso agrícola do lodo de esgotos demanda uma organização gerencial e técnica criteriosa, para que haja total segurança sanitária, ambiental e para que, ao mesmo tempo, o agricultor possa tirar o máximo proveito possível do uso do lodo de esgoto. Os principais parâmetros de interesse agronômico dos lodos produzidos em algumas ETEs do Brasil foram compilados e estão apresentados na Tabela 3.7. 
Tabela 3.7 - Principais parâmetros de valor agronômico dos lodos produzidos em ETEs do Brasil.

\begin{tabular}{lrrrrrrrr}
\hline \multirow{2}{*}{ Parâmetro } & \multicolumn{7}{c}{ Estação de Tratamento de Esgoto } \\
\cline { 2 - 10 } & Barueri & Franca & Suzano & Lavapés & Bertioga & Humaitá & Bichoró & Belém \\
\hline Nitrogênio total (\%) & 2,25 & 5,53 & 2,31 & 4,5 & 3,93 & 4,1 & 4,84 & 4,91 \\
\hline Fósforo (\%) & 1,48 & 0,93 & 2,65 & 2,59 & 2,6 & 0,6 & 2,89 & 3,7 \\
\hline Potássio (\%) & 0,01 & 0,26 & 0,1 & 0,39 & 0,35 & 0,15 & 0,1 & 0,36 \\
\hline Matéria orgânica (\%) & 44 & 65,2 & 41 & 52,6 & 68,43 & 63,43 & 71,35 & 69,4 \\
\hline Cálcio (\%) & 7,29 & 2 & 14,6 & 13,3 & 1,3 & 1,95 & 0,63 & 1,59 \\
\hline Magnésio (\%) & $\mathrm{ND}$ & 0,22 & 0,22 & 0,27 & 0,37 & 0,27 & 0,24 & 0,6 \\
\hline Zinco (mg/Kg) & 990 & 1560 & 2705 & 682 & 437,8 & 549,3 & 555,7 & ND \\
\hline Cobre (mg/Kg) & 348 & 160 & 543 & 120 & 136 & 136,4 & 231,3 & ND \\
\hline Ferro (mg/Kg) & 15117 & 11995 & 40454 & 10461 & 66622 & 8064 & 69348 & ND \\
\hline pH & 11 & 6,3 & 11,5 & 12,6 & 6,7 & 5,6 & 3,9 & 5,9 \\
\hline Fonte: Tsutiya
\end{tabular}

Fonte: Tsutiya (2001a)

Após a publicação da Resolução CONAMA N³75/2006, o Conselho do Meio Ambiente do Distrito Federal - CONAM publicou, em 18 de Julho de 2006, a Resolução CONAM $\mathrm{N}^{\circ}$ 03/2006, que atualmente, regulamenta os mecanismos e procedimentos para o uso agrícola do Lodo de Esgoto no Distrito Federal. As concentrações máximas admissíveis no lodo para esse fim, definidas na Resolução CONAM N03/2006, são apresentadas nas Tabelas 3.8 e 3.9 a seguir:

Tabela 3.8 - Concentrações máximas permissíveis de metais em lodos de esgoto para aplicação no solo

\begin{tabular}{lc}
\hline \multirow{1}{*}{ Elemento } & \begin{tabular}{c} 
Concentrações limite - base seca $\left(\mathbf{m g ~ k g}^{-1}\right)$ \\
\cline { 2 - 2 }
\end{tabular} \\
\cline { 2 - 2 } & $\begin{array}{c}\text { após a publicação da norma } \\
\text { a partir do } 8^{\mathrm{a}} \text { ano }\end{array}$ \\
\hline Arsênio & 20 \\
Bário & 650 \\
Cádmio & 13 \\
Cobre & 1.000 \\
Chumbo & 250 \\
Cromo & 500 \\
Mercúrio & 4 \\
Molibdênio & 25 \\
Níquel & 210 \\
Selênio & 8 \\
Zinco & 2.000 \\
\hline
\end{tabular}

Fonte: Resolução CONAM N 03/2006

Em acordo com a Resolução CONAM n03/2006 do Distrito Federal, para fins de utilização agrícola, o lodo de esgoto ou produto derivado deve apresentar o teor de cinzas, tanto nos lodos de esgoto Classes A e B, superior a 25\% (base seca). 
Tabela 3.9 - Valores máximos para agentes patogênicos no lodo de esgoto Classe A e B de acordo com a Resolução nº 003/2006 - CONAM

\begin{tabular}{|c|c|c|}
\hline \multirow{2}{*}{ Parâmetro } & Máximo Admissível & Máximo Admissível \\
\hline & Lodo de Esgoto Classe A & Lodo de Esgoto Classe B \\
\hline $\begin{array}{l}\text { Coliformes } \\
\text { termotolerantes }\end{array}$ & $10^{3} \mathrm{NMP} / \mathrm{g}$ de matéria seca & $2 \times 10^{6} \mathrm{NMP} / \mathrm{g}$ de matéria seca \\
\hline $\begin{array}{l}\text { Ovos viáveis de } \\
\text { helmintos }\end{array}$ & $\begin{array}{l}\text { menor que } 1 \text { ovo a cada } 4 \mathrm{~g} \mathrm{de} \\
\text { matéria seca }\end{array}$ & \\
\hline Salmonella sp. & ausência em $10 \mathrm{~g}$ de matéria seca & \\
\hline Vírus entéricos & $\begin{array}{l}\text { menor que } 1 \text { UFP ou UFF por } 4 \\
\text { g de matéria seca }\end{array}$ & \\
\hline $\begin{array}{l}\text { Cistos viáveis de } \\
\text { protozoários }\end{array}$ & $\begin{array}{l}\text { menor que } 1 \text { a cada } 4 \mathrm{~g} \\
\text { dematéria seca }\end{array}$ & \\
\hline
\end{tabular}

II - Uso do lodo em áreas de reflorestamento

Tsutya (2001b) ressalta que a aplicação do lodo em plantações florestais deve ser considerada à parte do uso agrícola. Essa afirmação corrobora o que afirmam Hart et al. (1988), citando outros autores, ressaltando as vantagens do uso de lodo de esgotos em sistemas florestais em comparação com os sistemas agrícolas. Entre as vantagens citadas pelos autores estão:

- os produtos das culturas florestais, normalmente não são comestíveis, diminuindo os riscos de contaminação pela entrada de compostos na cadeia alimentar;

- os ciclos das culturas florestais são mais longos e a acumulação da biomassa contribui para a remoção de possíveis elementos perigosos do solo;

- melhor aproveitamento dos nutrientes, visto que os solos florestais são, em geral, muito pobres e o sistema radicular perene aumenta a eficiência de absorção dos elementos;

- menor risco de contato humano após a aplicação de lodo;

- o ciclo longo das culturas florestais permite intervalos mais longos e favorecem a dinâmica entre as aplicações.

Em pesquisas mais recentes, Lira et al. (2008), avaliando como o lodo de esgoto altera os estoques de $\mathrm{C}$ e $\mathrm{N}$ em plantação de eucalipto, concluíram que o biossólido foi capaz de fornecer $\mathrm{N}$ aos eucaliptos tanto quanto a adubação mineral, confirmando que o resíduo pode ser empregado para o suprimento desse nutriente em plantações florestais. 
Poggiani et al. (2006), ao avaliar a influência de dois tipos diferentes de lodo de esgoto (úmido e seco), aplicados em diferentes doses, no crescimento e na ciclagem dos nutrientes em parcelas experimentais de Eucalyptus grandis, observaram que a aplicação do lodo influenciou de maneira positiva o crescimento do eucalipto, servindo como fonte de nutrientes nessa fase inicial de crescimento. Houve maior produção de biomassa pelos eucaliptos que receberam o lodo, superior a biomassa dos eucaliptos do tratamento testemunha e, em média, maior também do que na fertilização mineral. Verificaram também que a utilização do lodo influenciou nos valores de concentração foliar de alguns nutrientes principalmente $\mathrm{P}, \mathrm{Zn}$ e $\mathrm{Mn}$.

Guedes (2005) em seu estudo sobre como a utilização do lodo de esgotos pode afetar ciclagem biogeoquímica de nutrientes, em um povoamento de Eucalyptus grandis, concluiu que a aplicação de lodo alterou o desenvolvimento e o estado nutricional dos eucaliptos e, ainda, os padrões de reciclagem dos nutrientes. Nesse estudo foi verificado um significativo aumento da produção de serapilheira e da devolução de nutrientes ao solo.

III - Recuperação de áreas degradadas

Experiências com o uso de lodo para recuperação de áreas degradadas têm demonstrado resultados bastante promissores. Um extenso estudo, para remediação de área contaminada com resíduos de indústrias de fundição e de mineradoras, foi realizado entre 1994 e 1999, na Polônia. O estudo foi conduzido por pesquisadores poloneses, com o apoio da Environmental Protection Agency - EPA. Segundo concluíram os autores, o uso do lodo para remediação da área foi bem sucedido, podendo servir como um modelo para recuperação de áreas semelhantes em todo o mundo. O projeto demonstrou que os biossólidos podem ser usados com eficácia para ajudar a revegetação de áreas contaminadas com resíduos altamente tóxicos, apresentando-se como uma alternativa aos métodos tradicionais.

O lodo de esgoto apresenta uma série de características que favorecem a recuperação e o aparecimento da vegetação em áreas degradadas, onde os solos são pobres em matéria orgânica e nutrientes.

Os métodos tradicionais de recuperação dessas áreas, especialmente em áreas resultantes da exploração de minérios e jazidas de areia, têm sucesso limitado, pois são solos, em 
geral, pobremente desenvolvidos, carentes de matéria orgânica, nutrientes e com baixa capacidade de retenção de água necessária para sustentar a vegetação. Nestes casos, uma aplicação de fertilizantes químicos não contribui para o estabelecimento de autossustentação da vegetação, a longo prazo, como também não acarreta melhorias das condições estruturais do solo. A aplicação de corretivos orgânicos foi selecionada como um método complementar às práticas de recuperação de áreas degradadas, vencendo as limitações das técnicas mais tradicionais.

Quando aplicados com sobrecarga, os biossólidos aumentam a matéria orgânica no solo, melhorando a capacidade de retenção de água e promovendo o fornecimento de nutrientes por um longo período. A recuperação de áreas degradadas, associada ao uso do lodo de esgoto, com espécies florestais nativas, possui as mesmas vantagens apontadas para o uso do resíduo em plantios florestais comerciais, tais como (Gonçalvez et al., 2001; Pogiani et al., 2000):

1. a redução dos custos com fertilizantes em áreas geralmente extensas, particularmente quanto a reposição de $\mathrm{N}$ e P;

2. absorção de nutrientes durante boa parte do ano pelas raízes perenes (lenta liberação dos elementos), geralmente explorando grandes volumes de solo;

3. capacidade de imobilizar grandes quantidades de nutrientes e de metais pesados pela grande produção e distribuição de carbono orgânico;

4. não associação, em geral, do produto florestal final com a produção de alimentos, propiciando baixos riscos à saúde pública.

IV - Uso do lodo na fabricação de substrato vegetal

O uso do lodo de esgotos na fabricação de diferentes composições de substratos, para a produção de mudas em viveiros, vem sendo objeto de diversas pesquisas. Isso ocorre porque o seu uso como um dos componentes do substrato tem se mostrado promissor, visto ser uma fonte de macro e micronutrientes (Bonnet et al., 1999; Trigueiro e Guerrini, 2003; Cunha et al., 2006; Faustino et al., 2005). No entanto, deve ser dada a devida atenção aos diferentes percentuais dos componentes, já que resultam em diferentes quantidades de nutrientes, oxigênio e capacidades de retenção hídrica (Trigueiro e Guerrini, 2003). 
Além do benefício ambiental, o uso de lodo de esgoto na composição de substratos permite uma economia na adubação suplementar e melhorias no percentual de aproveitamento do viveiro. Trigueiro e Guerrini (2003), em pesquisa utilizando lodo de esgoto para a produção de mudas de eucalipto, obtiveram uma economia de fertilizante na ordem de $64 \%$.

Scheer et al. (2010) avaliaram o crescimento de Parapiptadenia rigida (Benth.) Brenan (gurucaia) em substratos de lodo de esgoto aeróbio compostado com restos de podas de árvores trituradas, com diferentes níveis de fertilizante e comparou o crescimento das mudas produzidas com os substratos à base de lodo de esgoto com o uso de substrato comercial, amplamente utilizado em viveiros florestais. As proporções de lodo de esgoto utilizadas na compostagem com podas de árvores trituradas resultaram em substratos bastante promissores. Para a Parapiptadenia rigida (gurucaia) os resultados de crescimento (altura, diâmetro de colo, biomassa de ramos e de folhas) foram maiores do que os obtidos pelos tratamentos utilizando substrato comercial à base de casca de Pinus compostada e vermiculita, indicando provavelmente, boas características físico-hídricas e nutricionais. Apesar das mudas nos compostos à base de lodo de esgoto responderem bem à fertilização complementar, os nutrientes já existentes neles são suficientes para a formação de plantas com boa qualidade.

Segundo Andreoli et al.(2006), a composição e as propriedades físico-químicas e sanitárias dos substratos são variáveis em função de sua origem, método de produção e obtenção, proporções de seus componentes entre outras. A qualidade do substrato também relaciona os níveis de contaminação com elementos como metais pesados, patógenos e sementes de plantas invasoras. Por isso os autores recomendam que, no caso do lodo de esgotos, este seja previamente higienizado e analisado quimicamente a fim de evitar a contaminação do substrato.

V - Usos alternativos para o lodo de esgotos - aplicações na construção civil

A aplicação de lodo de esgotos na construção civil vem sendo investigada há algumas décadas. $\mathrm{O}$ aproveitamento de resíduos nas indústrias de cerâmica branca não vem sendo difundido, visto que esse tipo de produto apresenta exigências quanto à composição, estabilidade físico-química, controle operacional e desempenho das peças. Nesse sentido, as indústrias de cerâmica vermelha e cimenteira apesentam um maior potencial de 
empregar resíduos na sua composição, pois suas composições podem apresentar valores de propriedades tecnológicas em faixas menos estritas (Junior et al., 2010).

Tay et al. (2002) pesquisaram a viabilidade de se utilizar a cinza do lodo gerado em estações de tratamento de esgotos para produzir tijolos. O lodo foi misturado à argila nas proporções de $10 \%, 20 \%, 30 \%, 40 \%$ e $50 \%$ em peso. Os resultados mostraram que à medida que o teor de lodo aumentava, a resistência à compressão se reduzia. Sendo que para a amostra com 50\%, a redução da resistência chegou a $20 \%$ em relação à amostra de referência.

A incorporação do lodo de esgotos na fabricação de produtos cerâmicos, como telhas, tubos, tijolos e lajotas, tem-se mostrado uma alternativa viável de destinação adequada. $\mathrm{O}$ lodo é adicionado ao processo durante a etapa de preparação da massa cerâmica e auxilia na correção de umidade. Isso pode ser feito manualmente, com pás carregadeiras, ou em olarias mais tecnificadas, utilizando-se equipamentos apropriados (ANDREOLI et al., 2006).

Morales e Agopyan (1992, apud Fontes, 2003) utilizaram o lodo de esgoto produzido na cidade de Londrina, para produzir agregado leve. Dos estudos realizados concluíram que o produto final apresentou características compatíveis com os requisitos e critérios estabelecidos pelas especificações brasileiras no que tange a produção de elementos de concreto para alvenaria, produção de concreto estrutural ou para isolamento térmico.

Khanbilvard e Afshari (1995, apud Fontes, 2003) incineraram o lodo produzido na ETE de Bergen Point e avaliaram o comportamento dos concretos devido a uma substituição parcial da areia natural por lodo de esgoto. O teor de substituição foi de até $30 \%$ onde puderam concluir que a resistência à compressão, aos 28 dias, foi reduzida à medida em que o teor de lodo aumentava (em torno de $20 \%$ em relação ao concreto de referência).

Segundo Geyer (2001), a produção de agregado leve tem encontrado dificuldades em entrar no mercado, devido ao seu custo elevado em comparação com as alternativas disponíveis.

Onaka (2000) relata que no Japão cerca de $70 \%$ das tortas de lodo é incinerada. Parte da cinza e da escória derretida é usada na agricultura e na fabricação de materiais de 
construção, como agregados leves, escória derretida para base de pavimentação, tijolos e blocos de piso intertravados, mas a maior parte é disposta em aterros.

Onaka (2000) testou, em 1998, o uso de lodo de esgoto numa fábrica de cimento. No processo o lodo entrava no forno com a matéria-prima do cimento e eram queimados juntos. A matéria orgânica era toda utilizada como fonte complementar de calor e a parte inorgânica ligava-se ao clínquer produzido. Os traços de metais pesados foram fixados em teores ainda mais diluídos na massa do cimento. O monitoramento dos gases e o controle de qualidade do produto não indicaram nenhuma alteração em relação aos valores sem o uso do lodo.

Feitosa (2009), em sua pesquisa com estudos alternativos do aproveitamento do lodo de esgoto, analisou o uso de lodo tratado de uma ETE para melhoramento de um solo colapsível, uma areia siltosa, classificada como solo A-2-4. Foram adicionados 5\%, 10\% e $15 \%$ de lodo em substituição a massa de solo e os resultados foram satisfatórios. Dentre as conclusões sobre mistura e materiais envolvidos, observou-se que os lodos não poderiam ser considerados como um resíduo único, pois foram utilizados lodos de diferentes tipos de ETE. O autor verificou alterações físicas, químicas e micro estruturais no solo depois da adição de lodo ao solo natural. Ao manter o mesmo peso específico aparente seco da mistura solo-lodo, observou que ao acrescentar lodo ocorreu a redução do índice de vazios do solo, conduzindo a uma menor compressibilidade ao adicionar o lodo. O lodo mostrouse adequado para melhoramento de solos colapsíveis.

Fontes (2008) fez uso da adição de cinza de lodo de esgoto, juntamente com a de resíduo sólido urbano como aditivo mineral para produção de concreto de alto desempenho. Os testes demonstraram que tanto a incorporação de cinza de lodo como a cinza de resíduo sólido urbano mostraram-se como uma alternativa viável do ponto de vista técnico e ambiental.

Apesar da viabilidade verificada nos estudos realizados, a utilização do lodo de esgoto na construção civil tem sido mais frequente nos países ou regiões onde surgem fatores altamente limitantes às formas tradicionais de descarte do lodo, tais como a disposição em aterros sanitários ou uso agrícola. Entre os problemas que podem levar a busca de outras aplicações para o lodo estão: consumo de combustível da incineração, comprometimento 
da qualidade do lodo - restringindo sua disposição no solo, aumento das restrições ao uso agrícola, sazonalidade da agricultura e a falta de áreas para aterros.

\subsection{CONSIDERAÇÕES GERAIS SOBRE A SELEÇÃO DO TRATAMENTO ADEQUADO DE LODO}

A tecnologia do tratamento do lodo deve ser escolhida tendo em conta não apenas as características da ETE e dos resíduos gerados, mas também deve estar relacionada com o destino final pretendido para o biossólido (Fernandes et al., 2001), bem como com os impactos durante o seu processo de transformação ou aqueles decorrentes do seu uso.

No caso da disposição do lodo líquido no solo, consideram-se os seguintes aspectos: a ETE deve estar próxima às áreas agrícolas e não produzir um volume total de lodo muito alto, assim, este pode ser preparado para a reciclagem agrícola utilizando-se etapas de tratamento como o adensamento, a estabilização e a higienização, dispensando-se a fase de desidratação.

Se o destino final do lodo não for a disposição agrícola, mas pretende-se dispô-lo em aterros sanitários, a etapa de estabilização pode ser dispensada, pois dentro das células do aterro sanitário ocorre uma degradação anaeróbia da matéria orgânica. Deve-se pensar, entretanto, que o volume a ser disposto é um fator limitante e os métodos para redução de volume - desaguamento do lodo - são eficientes quando o lodo apresenta bom grau de estabilização.

O condicionamento é uma preparação do lodo para a etapa de desidratação. Em alguns casos, dependendo das condições locais, esta fase do tratamento não se justifica, como, por exemplo: a desidratação em leitos de secagem, os quais são muito utilizados em regiões de clima quente. Quando é necessário aplicar o condicionamento ao lodo, a escolha do produto químico a ser utilizado, assim como a sua dosagem, dependerá do tipo de lodo a ser processado.

Algumas alternativas de destino final requerem lodo com uma faixa bem definida de sólidos. Na secagem térmica ou incineração, o lodo deve apresentar no mínimo $35 \%$ de sólidos, todavia, a eficiência deste processo aumenta quanto maior for a concentração de matéria seca. Em se tratando da compostagem, geralmente o teor ideal de sólidos se 
encontra na faixa de 15 a 20\% e vai depender do resíduo estruturante utilizado (Fernandes et al., 2001). Lodos desidratados com alto teor de sólidos, como aqueles produzidos em leitos de secagem, não são muito adequados para a compostagem, pois neste tipo de tratamento são usados resíduos estruturantes como: serragem de madeira, restos triturados de podas de árvores, dentre outros, para equilibrar a relação C:N. as misturas dos resíduos na compostagem devem apresentar uma umidade ente 55 e $65 \%$. A desidratação do lodo tem um importante papel nos custos de transporte e destino final do lodo e, como o comportamento do lodo varia com o teor de umidade, esta também vai influenciar, de maneira decisiva, o manuseio do lodo (Fernandes et al., 2001).

Quando o destino final do lodo for o uso agrícola, faz-se necessário uma etapa de higienização, visto que as alternativas de estabilização como as digestões anaeróbia e aeróbia do lodo, que são os processos mais usados, degradam a matéria orgânica e diminuem os maus odores, porém não são muito eficientes na eliminação de microrganismos patogênicos. 
A gestão do lodo proveniente de diferentes etapas do tratamento de esgotos, representa um problema de elevada complexidade. O conhecimento de suas características qualitativas e quantitativas, das variáveis operacionais que influenciam o desempenho das unidades de tratamento de lodos, assim como dos requisitos necessários às técnicas de tratamento e às alternativas de disposição final, formaram as linhas mestras para delineamento da presente pesquisa, que consistiu, basicamente, do cumprimento das atividades apresentadas na Figura 4.1.

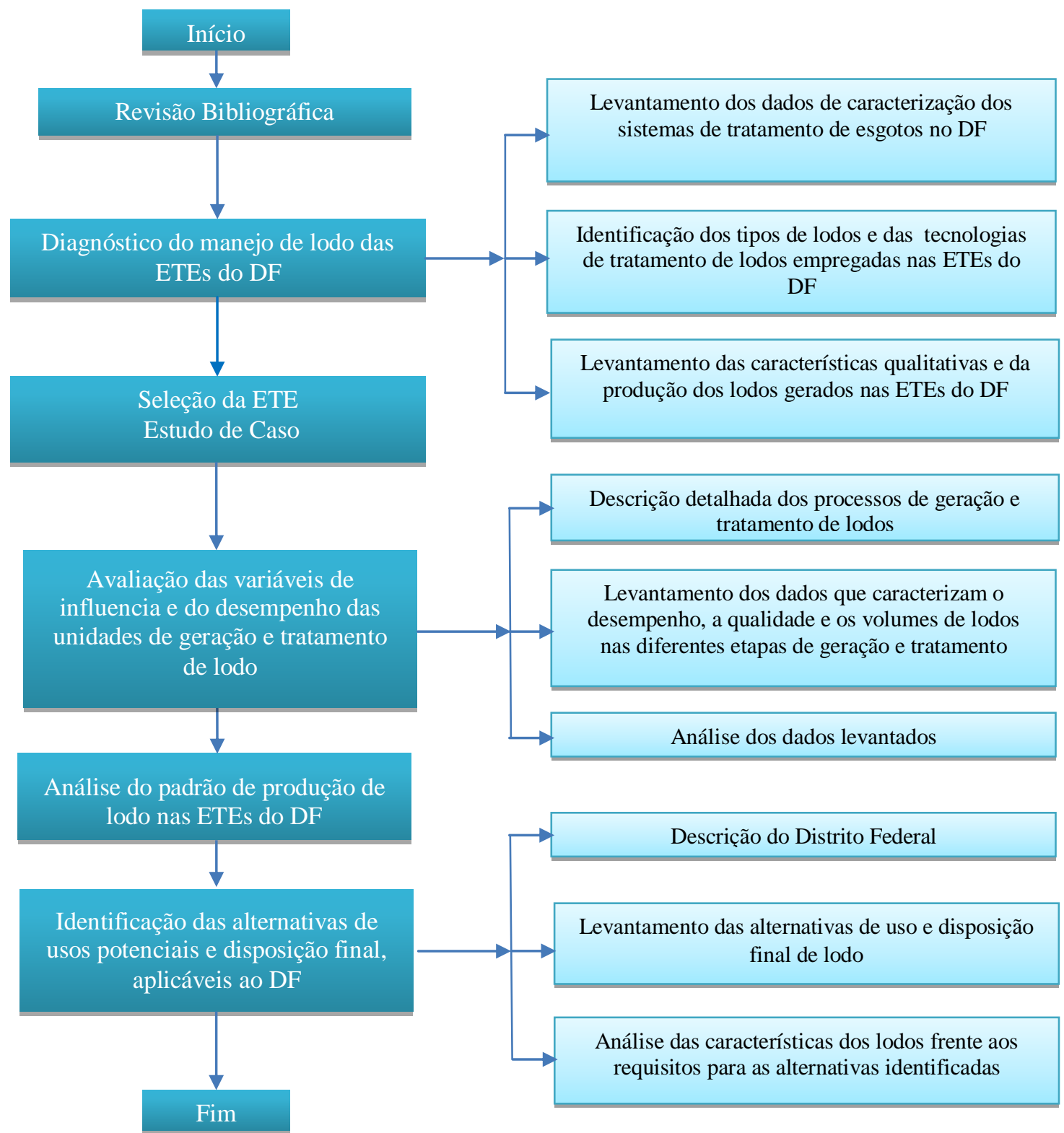

Figura 4.1 - Fluxograma das etapas e atividades necessárias ao desenvolvimento da pesquisa 


\subsection{DIAGNÓSTICO DO MANEJO DE LODOS DAS ETES DO DISTRITO FEDERAL}

Nesta etapa de diagnóstico, foram levantadas informações sobre todo o sistema de tratamento de esgotos domésticos do Distrito Federal, contemplando os seguintes assuntos, por estação de tratamento:

- nome da estação de tratamento de esgotos domésticos, localização, população atendida;

- tipo de processo de tratamento de esgoto doméstico empregado;

- vazão de tratamento atual, de esgoto afluente e de lodo efluente, e capacidade nominal (vazão de projeto) de cada estação;

- valores médios dos parâmetros característicos dos esgotos afluentes e remoções alcançadas para esses parâmetros (DBO, DQO, SS, entre outros); e

- condições atuais de adequação e disposição final de resíduos gerados no tratamento de esgotos (detritos e lodo) e demais dados disponíveis.

Os dados necessários ao desenvolvimento desse estudo foram disponibilizados pela CAESB e balizaram a caracterização das técnicas de manejo de lodo das 16 estações de tratamento de esgotos implantadas no DF. Esse material conta com os dados históricos dos últimos 10 anos, obtidos a partir de relatórios técnicos de desempenho das ETEs, dos relatórios anuais do sistema de esgotamento sanitário - SIESG.

As informações levantadas incluíram a identificação dos sistemas de tratamento de lodo empregados nas diversas estações, descrevendo os processos de estabilização, condicionamento, desidratação e higienização do lodo, bem como os procedimentos de disposição final em vigor na concessionária de serviços de saneamento do Distrito Federal (CAESB). Para tanto, foram realizadas visitas às ETEs e entrevistas com os operadores do sistema.

Os dados técnicos, informações operacionais e resultados das análises físico-químicas catalogados, contemplaram os valores médios mensais, por estação de tratamento. A utilização de planilhas eletrônicas possibilitou a sistematização de resultados, a caracterização preliminar das tecnologias empregadas no processamento do lodo, da produção e da qualidade desse lodo. 


\subsubsection{Caracterização qualitativa do lodo desaguado para fins de disposição final}

As aplicações possíveis dos lodos de esgotos, em princípio, devem considerar, entre outros aspectos, suas características e volume disponível. Por esta razão, a caracterização qualitativa do lodo desaguado se constitui em uma das linhas mestras para a análise das alternativas de disposição ambientalmente adequadas.

As séries históricas de dados, atualmente disponíveis na CAESB, referem-se a informações sobre o lodo desaguado e são pertinentes ao controle da qualidade do tratamento. Apesar de importantes, essas informações não são suficientes para fundamentar uma decisão da melhor alternativa de disposição do resíduo. Assim, os dados das áreas operacionais foram complementados, por meio dos planos de caracterização de lodo, realizados para a CAESB, por laboratórios externos contratados para esse fim.

Os planos de caracterização contemplaram exames específicos, visando estabelecer a composição física e química dos lodos de esgotos, bem como o potencial agronômico do

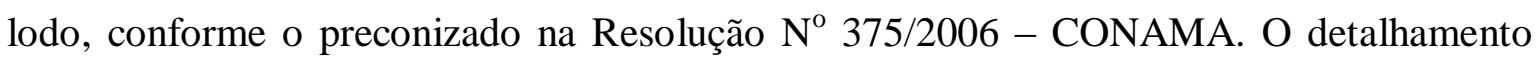
dos parâmetros e dos métodos de determinação é apresentado nas Tabelas 4.1 e 4.2. Essas informações foram analisadas em conjunto com os dados de trabalhos científicos desenvolvidos com o lodo das ETEs do Distrito Federal e outras ETEs similares. A Tabela 4.1 contém uma lista desses parâmetros.

O monitoramento da qualidade microbiológica, para os parâmetros coliformes termotolerantes e ovos de helmintos, é realizado no laboratório de microbiologia da CAESB, e compreende dados do lodo desaguado dos últimos 7 anos de operação das ETEs do DF. 
Tabela 4.1 - Parâmetros de caracterização do Lodo

\begin{tabular}{c|c|c}
\hline AGRONÔMICO & INORGÂNICOS & BIOLÓGICOS \\
\hline \hline Carbono Orgânico & Arsênio & Coliformes Termotolerantes \\
\hline Fósforo Total & Antimônio & Ovos viáveis de helmintos \\
\hline Nitrogênio Kjeldahl & Bário & \\
\hline Nitrogênio Amoniacal & Cádmio & \\
\hline Nitrogênio de Nitrato & Chumbo & \\
\hline Nitrogênio de Nitrito & Cobre & \\
\hline pH (água) & Cromo Total & \\
\hline Potássio & Mercúrio & \\
\hline Sódio & Molibdênio & \\
\hline Enxofre Total & Níquel & \\
\hline Cálcio Total & Selênio & \\
\hline Magnésio Total & Zinco & \\
\hline Teor de sólidos & & \\
\hline Sólidos Totais Voláteis & & \\
\hline Sólidos Totais & & \\
\hline Alumínio Total & & \\
\hline Ferro Total & & \\
\hline \multicolumn{2}{|r|}{} & \\
\hline
\end{tabular}

Tabela 4.2 - Metodologias analíticas para determinação dos parâmetros de interesse

\begin{tabular}{|c|c|c|}
\hline & Parâmetro & Método \\
\hline \multirow{9}{*}{ 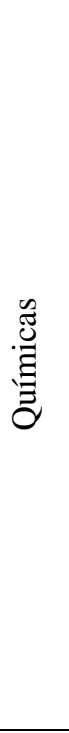 } & $\begin{array}{l}\text { Cálcio }^{2} \\
\text { Magnésio }^{2} \\
\text { Sódio }^{2} \\
\text { Potássio }^{2} \\
\text { Metais }^{2} \text { (Al, Ba, Cd, Cr, Cu, Pb, Mo, Ní, Zn, As, Se, } \\
\mathrm{Hg} \text { ). }\end{array}$ & $\begin{array}{l}\text { Espectrometria de absorção atômica } \\
\text { (EAA) e Espectrometria de plasma } \\
\text { indutivamente acoplado (EPIA). }\end{array}$ \\
\hline & $\mathrm{pH}$ & Potenciométrico \\
\hline & Fósforo Total ${ }^{2}$ & Fósforo Total - Cloreto Estanoso \\
\hline & Nitrogênio Total $^{2}$ & Nitrogênio Orgânico Total Kjeldahl \\
\hline & Nitrato, Nitrito ${ }^{2}$ & $\begin{array}{l}\text { Espectrometria UV-Visível - } \\
\text { Diazotação }\end{array}$ \\
\hline & Amônia $^{2}$ & Nesslerização \\
\hline & Carbono Orgânico Total ${ }^{2}$ & Método Walkley - Black \\
\hline & Enxofre Total $^{2}$ & Turbidimetria \\
\hline & $\begin{array}{l}\text { Sólidos Totais e Sólidos Totais Voláteis, Sólidos em } \\
\text { Suspensão }\end{array}$ & Gravimetria \\
\hline \multirow{2}{*}{$\begin{array}{l}\frac{\pi}{0} \\
\frac{0}{0} \\
\frac{0}{0} \\
\frac{0}{\infty}\end{array}$} & Ovos viáveis de helmintos ${ }^{3}$ & Yanko \\
\hline & Coliformes termotolerantes ${ }^{3}$ & Tubos múltiplos \\
\hline \multirow{2}{*}{$\frac{\tilde{E}}{\tilde{\tilde{N}}}$} & Teor de umidade ${ }^{1}$ & Gravimetria \\
\hline & Cinzas $\left(\mathrm{a} 800^{\circ} \mathrm{C}\right)^{2}$ & Gravimetria \\
\hline
\end{tabular}

Legenda: (1) Laboratório de lodo da ETEB Norte (CAESB)

(2) Plano de caracterização CAESB

(3) Laboratório Microbiologia ETEB Norte (CAESB) 


\subsubsection{Caracterização quantitativa dos lodos gerados nas ETEs do Distrito Federal}

Os dados disponibilizados pela CAESB, referentes ao volume de lodo gerado nas ETEs do Distrito Federal, dizem respeito apenas aos volumes de lodo desaguados. Não existem controles internos, na grande maioria das ETEs, quanto aos volumes de lodos gerados nas fases intermediárias, dificultando uma análise mais acurada dos montantes de lodo produzidos ao longo das etapas de tratamento de esgotos.

Para aquelas ETEs que dispõem de unidade de desaguamento de lodo, foram obtidos dados dos volumes de lodos afluentes à desidratação. Esses dados foram analisados em conjunto com os dados de carga orgânica afluente à ETE e a carga orgânica removida, em $\mathrm{KgDBO} / \mathrm{d}$, de maneira a gerar um indicador que possibilitasse a visualização do volume de lodo gerado por $\mathrm{m}^{3}$ de esgoto tratado, segundo a seguinte determinação apresentada na equação 4.1:

$$
I=\frac{V_{\mathrm{L}}}{\operatorname{COa}-\mathrm{COe}}
$$

Onde:

I: indicador de produção volumétrica de lodo, $\mathrm{m}^{3}{ }_{\text {lodo }} / \mathrm{KgDBO}_{\text {removida }}$

$\mathrm{V}_{\mathrm{L}}$ : Volume de lodos afluentes, $\mathrm{m}^{3} / \mathrm{d}$

COa: Carga Orgânica afluente, $\mathrm{KgDBO} / \mathrm{d}$

COe: Carga Orgânica efluente, $\mathrm{KgDBO} / \mathrm{d}$

\subsection{ESTUDO DE CASO}

O Distrito Federal é atendido por estações de tratamento de esgotos com configurações bastante distintas. Algumas possuem processos de tratamento de esgotos simplificados como as estações do Torto e de Brazlândia, outras possuem fluxogramas complexos como, por exemplo, as estações Brasília Norte, Brasília Sul, Gama e Melchior (SIESG, 2013).

O processo de tratamento de esgotos, ao longo de suas etapas, dá origem a diferentes tipos de lodo de esgotos, esses, por sua vez, passam por fases distintas de tratamento, segundo suas características, concepção do processo de tratamento e destinação final a ser dada ao lodo. 
Para balizar o estudo do comportamento e a avaliação de parâmetros de influência do lodo gerado nas ETEs do Distrito Federal, foi necessário um detalhamento dos processos. Para isso, foi selecionada a estação Brasília Norte para ser objeto de Estudo de Caso.

A seleção desta unidade deveu-se ao fato de ela apresentar condições operacionais estáveis; de suas estruturas e instalações encontrarem-se preservadas; de possuir um controle operacional mais sistematizado e, principalmente, por ter condições de garantir a representatividade tanto da variabilidade de lodos gerada quanto dos tratamentos a que estes são submetidos.

\subsubsection{Descrição da Estação de Tratamento Brasília Norte - ETEB Norte}

A Estação de Tratamento de Esgotos de Brasília Norte (Figura 4.2), localizada na bacia de drenagem do lago Paranoá, iniciou sua operação em 1969, com tecnologia de lodos ativados convencional. Entretanto, devido ao estado de eutrofização do lago, na década de 80 essa estação, juntamente com a estação Brasília Sul, teve seu processo modificado para um sistema de tratamento em nível terciário/avançado, com remoção de nutrientes (fósforo e nitrogênio). A nova planta foi inaugurada em 1994, com capacidade para tratar uma vazão média de $920 \mathrm{~L} / \mathrm{s}$ e atender a uma população de cerca de 260.000 habitantes (SIESG,2013).

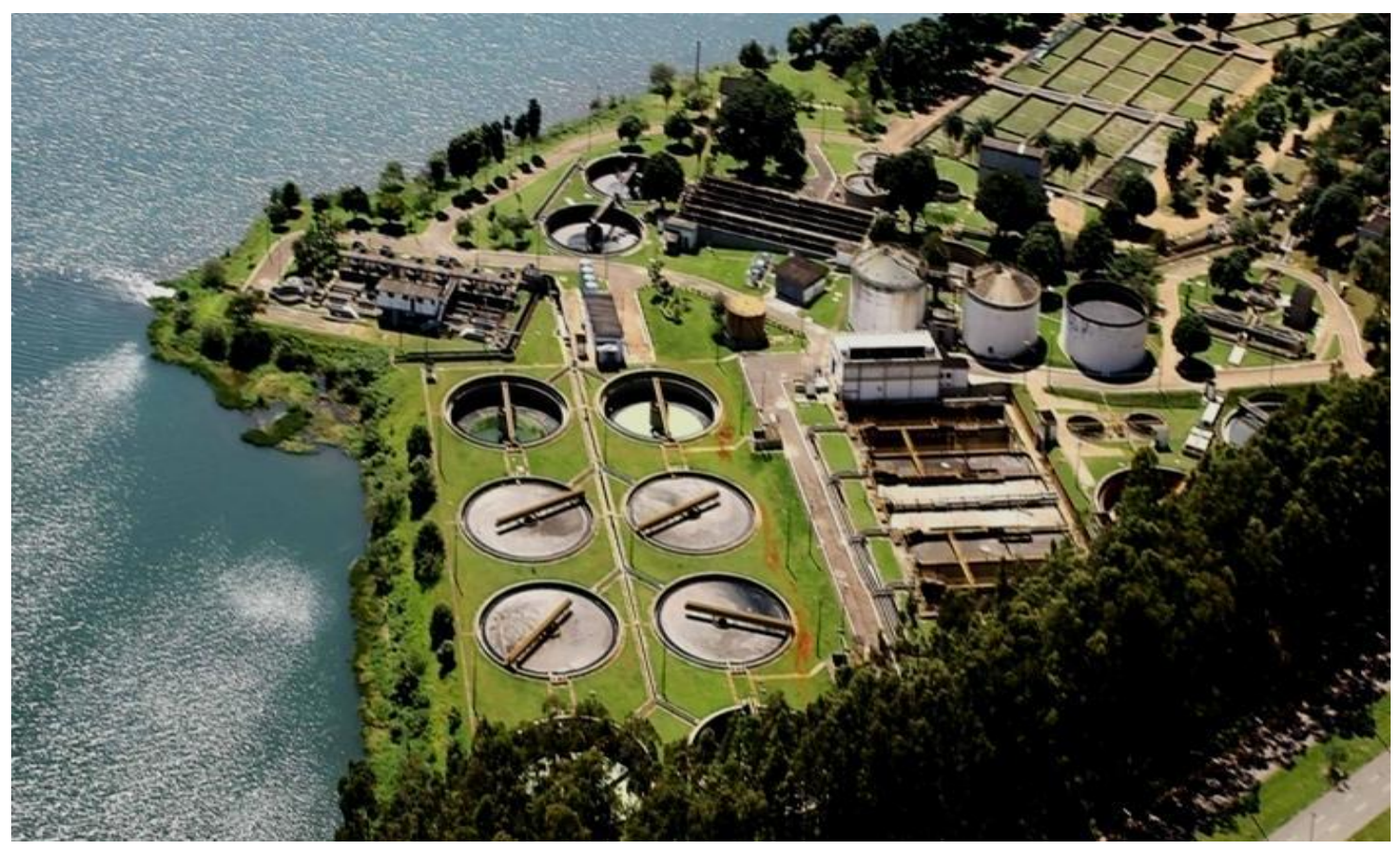

Figura 4.2 - Vista aérea da estação de tratamento de esgotos Brasília Norte 
Nessa estação, os esgotos sanitários domésticos coletados são encaminhados, por gravidade e por bombeamento, para a entrada da estação. A carga hidráulica afluente ao tratamento é controlada por uma comporta podendo, em parte, ser desviada para um sistema de estocagem de esgoto bruto, que funciona como um sistema de equalização de vazão, conferindo mais flexibilidade ao processo. $\mathrm{O}$ volume estocado retorna ao processo principal, por bombeamento, nos horários de baixa carga hidráulica.

O processo de tratamento de esgotos compreende cinco etapas, as quais estão detalhadas na Figura 4.3: tratamento preliminar, tratamento primário, tratamento secundário/terciário, tratamento químico e tratamento da fase sólida, esse último inclui todas as unidades de tratamento de lodo.

No tratamento preliminar são retirados os materiais grosseiros (estopa, plástico, lixo) e areia. Nos decantadores primários, fase seguinte do processo denominada tratamento primário, os esgotos são separados em duas fases, sólida e líquida.

A fase líquida, com quantidade considerável de matéria orgânica, é encaminhada ao tratamento secundário/terciário, onde micro-organismos aeróbios, anaeróbios e facultativos assimilam a matéria orgânica e os nutrientes. Os micro-organismos são separados da fração líquida já tratado nos decantadores secundários e retornam aos reatores biológicos para continuação do processo, ou são descartados para a linha de tratamento da fase sólida.

O líquido clarificado dos decantadores secundários segue para o tratamento químico ou polimento final, onde os sólidos e o fósforo remanescentes são removidos. A remoção é feita por meio de processos físico-químicos, empregando coagulação/floculação/flotação, com adição de produtos químicos (sulfato de alumínio e polieletrólito aniônico), e a separação por flotação. O efluente líquido final é lançado no lago Paranoá.

O tratamento da fase sólida engloba as diversas unidades que recebem os lodos produzidos nas etapas de tratamento de esgotos e compreende as fases de adensamento, digestão, condicionamento e desaguamento. Os sólidos separados no decantador primário, denominado lodo primário ou lodo bruto, são bombeados para os adensadores por gravidade e destes para os digestores anaeróbios. Aqueles lodos descartados nos reatores biológicos, lodo secundário, são adensados por flotação e, juntamente com os sólidos recolhidos pelos raspadores de superfície no polimento final, são também bombeados para 
os digestores anaeróbios. Depois da digestão, o lodo segue para o condicionamento químico e desidratação.

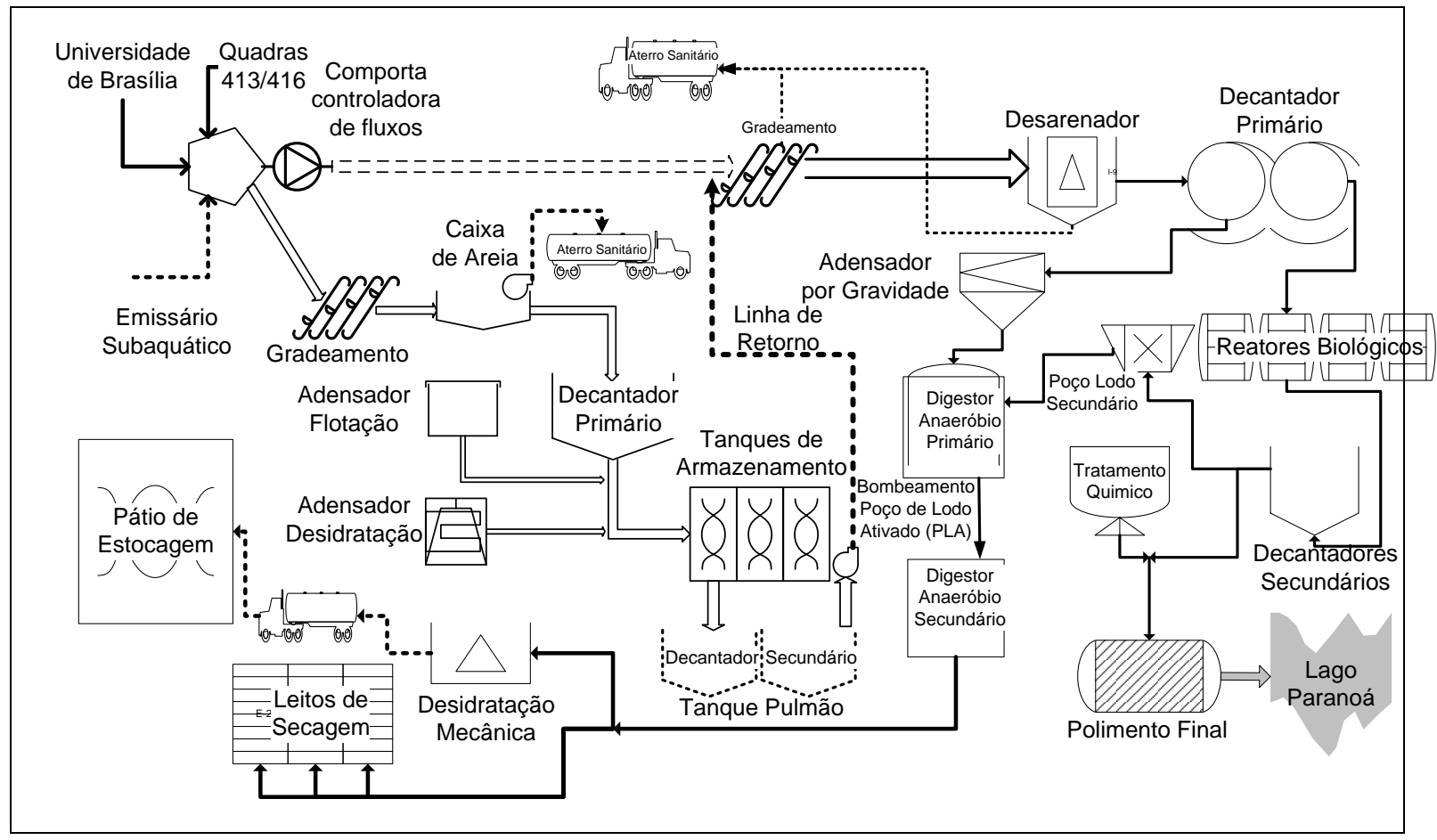

Figura 4.3 - Fluxograma de tratamento da ETE Brasília Norte Fonte: Nakazato (2005)

\subsubsection{Avaliação do desempenho das unidades de tratamento da fase sólida e do comportamento do lodo ao longo das etapas de geração.}

Foram realizados levantamentos específicos, para caracterização da ETE, que compõem o estudo de caso. As informações levantadas compreenderam uma descrição detalhada dos processos de geração e tratamento de lodos na ETE Brasília Norte, além do desenvolvimento das seguintes etapas:

a) caracterização quantitativa dos lodos em cada uma das fases de tratamento. Para isso foi necessário identificar:

- rotinas operacionais de descartes de lodo (primário, secundário, digerido, químico);

- controles e monitoramentos dos lodos, adotados em cada unidade;

- tipos de adensamento (adensador por gravidade, flotação, mecânico) e eficiência;

- processo de estabilização (digestão aeróbia, digestão anaeróbia, outra)

- condicionamento do lodo (produto químico utilizado, dosagem) 
- mecanismo de desidratação (natural ou mecânico; equipamento; capacidade instalada)

b) caracterização qualitativa dos lodos gerados, segundo os parâmetros de interesse a cada fase de tratamento;

c) análise estatística dos dados disponibilizados, com elaboração de gráficos e tabelas, de maneira a permitir a visualização do desempenho das diferentes unidades e da variabilidade no comportamento do lodo ao longo das etapas de tratamento.

Na Tabela 4.3 é apresentada uma lista das principais variáveis acompanhadas no estudo.

Tabela 4.3 - Parâmetros avaliados para o diagnóstico do comportamento do lodo.

\begin{tabular}{|c|c|c|c|}
\hline $\begin{array}{c}\text { Unidade de } \\
\text { processamento de } \\
\text { lodo } \\
\end{array}$ & $\begin{array}{c}\text { Indicadores da } \\
\text { Qualidade do } \\
\text { Lodo } \\
\end{array}$ & Desempenho & Variáveis operacionais \\
\hline $\begin{array}{c}\text { Decantador Primário } \\
\text { - DP } \\
\end{array}$ & $\begin{array}{l}\text { Concentração de } \\
\text { Sólidos }\end{array}$ & NA & NA \\
\hline $\begin{array}{l}\text { Adensador por } \\
\text { gravidade - ADG }\end{array}$ & $\begin{array}{l}\text { Concentração de } \\
\text { Sólidos }\end{array}$ & $\begin{array}{l}\text { Captura de } \\
\text { sólidos; }\end{array}$ & $\begin{array}{l}\text { - Taxa de aplicação de sólidos - } \\
\text { TAS; } \\
\text { - Tempo de detenção hidráulica - } \\
\text { TDH }\end{array}$ \\
\hline $\begin{array}{l}\text { Adensador por } \\
\text { Flotação - ADF }\end{array}$ & $\begin{array}{l}\text { Concentração de } \\
\text { Sólidos }\end{array}$ & $\begin{array}{l}\text { Captura de } \\
\text { sólidos; }\end{array}$ & $\begin{array}{l}\text { - Taxa de aplicação de sólidos - } \\
\text { TAS; } \\
\text { - Tempo de detenção hidráulica - } \\
\text { TDH. }\end{array}$ \\
\hline $\begin{array}{l}\text { Câmara de flotação - } \\
\text { PF }\end{array}$ & $\begin{array}{l}\text { Concentração de } \\
\text { Sólidos }\end{array}$ & $\begin{array}{l}\text { Captura de } \\
\text { sólidos; }\end{array}$ & $\begin{array}{l}\text { - Taxa de aplicação de sólidos - } \\
\text { TAS; } \\
\text { - Tempo de detenção hidráulica - } \\
\text { TDH. }\end{array}$ \\
\hline $\begin{array}{l}\text { Digestor anaeróbio } \\
\text { primário - DGP }\end{array}$ & $\begin{array}{l}\text { - Concentração de } \\
\text { Sólidos; } \\
\text {-SV/ST }\end{array}$ & $\begin{array}{l}\text { Remoção de } \\
\text { sólidos voláteis }\end{array}$ & $\begin{array}{l}\text { - Carga orgânica volumétrica - COV; } \\
\text { - Relação acidez/alcalinidade; } \\
\text { - pH }\end{array}$ \\
\hline $\begin{array}{l}\text { Desidratação } \\
\text { mecânica }\end{array}$ & $\begin{array}{l}\text { - \%ST; } \\
\text { - Umidade }\end{array}$ & $\begin{array}{l}\text { Captura de } \\
\text { sólidos }\end{array}$ & Volume de lodo desidratado. \\
\hline
\end{tabular}

Legenda: NA - Não aplicável

Foram investigadas as condições de funcionamento da estação a partir dos dados fornecidos pela CAESB e dos levantamentos em campo. O estudo contempla o tratamento estatístico de dados gerados diariamente, registrados em formulários operacionais, relativos aos volumes de lodo e líquidos drenados, além das rotinas operacionais relevantes para a consistência da avaliação. 
Foram analisados os sólidos gerados nas seguintes unidades: decantador primário, reator biológico, adensador por gravidade, adensador por flotação, câmara de flotação de lodo químico, e digestor anaeróbio.

Nessa etapa, atenção especial foi dada para as fases de adensamento, digestão e desidratação do lodo, visto serem etapas críticas para o gerenciamento adequado e para o equacionamento dos problemas de disposição final do lodo.

O desempenho dos adensadores de lodo foi avaliado por meio da análise do teor de sólidos totais e sólidos voláteis no lodo. Além disso, foram avaliados a captura de sólidos, a taxa de aplicação superficial de sólidos e o volume de lodo adensado enviado para os digestores, cujas equações são apresentadas na Tabela 4.4.

Tabela 4.4 - Tabela de variáveis operacionais e formulários aplicados ao estudo de caso da ETEB Norte

\begin{tabular}{|c|c|c|}
\hline $\begin{array}{c}\text { Variável de desempenho } \\
\text { e de controle }\end{array}$ & Formulário & Unidade \\
\hline Captura de sólidos & $\begin{array}{l}\text { Captura de sólidos }=\frac{V_{L} \times C_{L}-V_{L D} \times C_{L D}}{V_{L} \times C_{L}} \times 100 \\
\text { Onde: } \\
\mathrm{V}_{\mathrm{L}}: \text { Volume lodo, } \mathrm{m}^{3} / \mathrm{d} \\
\mathrm{C}_{\mathrm{L}}: \text { Concentração do lodo, } \mathrm{g} / \mathrm{m}^{3} \\
\mathrm{~V}_{\mathrm{LD}}: \text { Volume líquido drenado, } \mathrm{m}^{3} / \mathrm{d} \\
\mathrm{C}_{\mathrm{LD}}: \text { Concentração do líquido drenado, } \mathrm{g} / \mathrm{m}^{3}\end{array}$ & $\%$ \\
\hline $\begin{array}{l}\text { Taxa de aplicação de } \\
\text { sólidos (TAS) }\end{array}$ & $\begin{array}{l}\qquad \text { TAS }=\frac{\text { CargaSS }}{A} \\
\text { Onde: } \\
\text { CargaSS: Carga de sólidos aplicado à unidade, } \\
\text { KgSS/d } \\
\text { A: Área superficial da unidade, } \mathrm{m}^{2}\end{array}$ & $\begin{array}{l}\mathrm{KgSS} / \mathrm{m}^{2} \cdot \mathrm{d} \\
\quad \text { ou } \\
\mathrm{KgST} / \mathrm{m}^{2} \cdot \mathrm{d}\end{array}$ \\
\hline $\begin{array}{c}\text { Carga orgânica volumétrica } \\
\text { (COV) }\end{array}$ & $\begin{array}{l}\qquad \mathrm{COV}=\frac{\text { CargaSS }}{V} \\
\text { Onde: } \\
\text { CargaSS : Carga de sólidos aplicado à unidade, } \\
\text { KgSS/d } \\
\text { V : Volume da unidade, } \mathrm{m}^{3}\end{array}$ & $\begin{array}{l}\mathrm{KgSS} / \mathrm{m}^{3} \cdot \mathrm{d} \\
\text { ou } \\
\mathrm{KgSSV} / \mathrm{m}^{3} \cdot \mathrm{d}\end{array}$ \\
\hline $\begin{array}{l}\text { Tempo de detenção } \\
\text { hidráulica (TDH) }\end{array}$ & $\begin{array}{l}\qquad T D H=\frac{V}{Q_{L a f}} \\
\text { Onde: } \\
\text { V: Volume da unidade, } \mathrm{m}^{3} \\
\mathrm{Q}_{\text {Laf }} \text { : Vazão de lodo afluente, } \mathrm{m}^{3} / \mathrm{d} \mathrm{ou} \mathrm{m}^{3} / \mathrm{h}\end{array}$ & $\begin{array}{l}\text { dia } \\
\text { ou } \\
\text { Hora }\end{array}$ \\
\hline
\end{tabular}


Para se avaliar o desempenho dos digestores anaeróbios, foram analisados os parâmetros: $\mathrm{pH}$, ácidos voláteis, alcalinidade total. Além disso, foram determinados o tempo de detenção, carga orgânica volumétrica, remoção de sólidos voláteis e relação acidez volátil/alcalinidade total.

A desidratação do lodo da ETE Brasília Norte foi avaliada verificando-se as seguintes determinações: teor de sólidos totais e umidade, volume bombeado, produção diária da torta desidratada e a quantidade de produtos químicos (polímero) consumida para o condicionamento do lodo para o processo de desaguamento.

\subsection{ANÁLISE DO PADRÃo DE PRODUÇÃO DE LODOS DE ESGOTOS NAS ETES DO DF}

As informações relativas aos dados técnicos e aos parâmetros operacionais, por estação de tratamento, foram trabalhadas em conjunto com dados de população atendida pelo sistema coletor de esgotos, divulgados pela Companhia de Planejamento do Distrito Federal (CODEPLAN), e com parâmetros e coeficientes de produção de lodo, encontrados em bibliografia especializada. A população atendida, por região administrativa do DF, foi agrupada por bacia de contribuição de cada ETE.

Foram levantados os seguintes dados das estações de tratamento de esgotos do Distrito Federal: vazões atuais; as vazões de projeto de cada estação; as tecnologias de tratamento de esgotos empregadas, os processos de tratamento de lodo existentes e a eficiência operacional. O conhecimento desses dados, correlacionados com os dados populacionais, subsidiou a avaliação da produção teórica de lodos, para a condição atual de carga afluente às ETEs. Os valores determinados teoricamente foram, posteriormente, validados junto aos dados de operação dos sistemas, com vistas subsidiar a elaboração de cenários futuros de produção de lodos, auxiliando o planejamento da gestão dos resíduos de ETEs no DF.

Objetivou-se com isso, estabelecer os padrões de produção de lodo, nas diferentes etapas de geração, para as condições das estações do Distrito Federal, possibilitando a sistematização dos dados de quantidade, de forma a facilitar as projeções de produção de lodo e o planejamento de ações futuras. 
Dessa forma, o volume de lodo produzido foi obtido a partir da aplicação dos coeficientes de produção de lodo, população atendida, e percentuais de remoção para cada etapa de tratamento de esgoto e para cada ETE. Como a densidade do lodo ao longo das etapas de processamento é bem próxima a 1, por simplicidade, admitiu-se (Sperling, 2005):

$$
V_{\text {Lodo }}=\frac{\text { CargaSS }}{\frac{T_{S}}{100} \times \rho_{\text {Lodo }}}
$$

Onde:

- $\quad V_{\text {Lodo }}:$ Volume de lodo, em $\mathrm{m}^{3}$;

- CargaSS : Carga de sólidos em suspensão, em KgSS;

- $\rho_{\text {Lodo }}$ : massa específica do lodo, admitiu-se $\rho_{\text {Lodo }}=1000 \mathrm{Kg} / \mathrm{m}^{3}$;

- $\quad T_{S} \rightarrow$ Teor de sólidos no lodo, \%.

Assim, foi aplicada a equação 5.4, conforme a seguir:

$$
V_{\text {Lodo }}=\frac{\left(P a \times P_{L}\right) \div 1000}{T s \times 10}
$$

Onde:

- $V_{\text {Lodo }}$ : Volume de lodo, em $\mathrm{m}^{3}$;

- $P a$ : População atendida, em $\mathrm{N}^{\circ}$ habitantes;

- $P_{L}$ : Coeficiente de produção de lodo, gSS/hab.d;

- $\quad T_{S}:$ Teor de sólidos no lodo, $\%$.

Para o cálculo do volume de lodo nas unidades subsequentes a cada etapa de tratamento, foram consideradas as remoções esperadas e a partir daí, foram determinadas: a carga orgânica remanescente e a população equivalente (equação 5.2). Dessa forma, em uma estação com reator UASB seguido de lagoa facultativa, o volume do lodo foi determinado como a seguir:

$$
\begin{gathered}
V_{\text {LodoUASB }}=\frac{\left(\mathrm{Pa} \times \mathrm{P}_{L}\right) \div 1000}{T s \times 10} \\
C O_{\text {rem }}=C O_{\text {apl }} \times(1-R)
\end{gathered}
$$

Onde:

$\mathrm{R}$ - remoção esperada;

$\mathrm{CO}_{\text {rem }}$ - carga orgânica remanescente, em $\mathrm{KgDBO} /$ dia;

$\mathrm{CO}_{\text {apl-carga orgânica aplicada, em } \mathrm{KgDBO} / \text { dia }}$ 


$$
\begin{aligned}
& P e=\frac{C O_{r e m} \times 1000}{54} \\
& V_{\text {LodoLagoa }}=\frac{\left(P e \times P_{L}\right) \div 1000}{T S \times 10}
\end{aligned}
$$

\subsection{IDENTIFICAÇÃO DOS USOS POTENCIAIS DOS LODOS DE ESGOTOS, APLICÁVEIS AO DISTRITO FEDERAL}

O primeiro passo para o desenvolvimento desta etapa foi o levantamento das alternativas de disposição desse resíduo, obtido a partir da revisão bibliográfica, fornecendo o conhecimento das experiências nacionais e internacionais relativas ao processamento e utilização dos lodos de esgotos e outras alternativas de disposição final. Foram também levantados os requisitos e padrões exigidos para cada uma das aplicações identificadas.

Em seguida, foi necessário obter dados sobre a área de aplicação, o Distrito Federal. Foram utilizados, como fontes de dados, documentos publicados pelas seguintes instituições: CAESB - Companhia de Saneamento Ambiental do Distrito Federal, EMATER/DF Empresa de Assistência Técnica e Extensão Rural do Distrito Federal, EMBRAPA/Cerrados - Empresa Brasileira de Agricultura e Pecuária, NOVACAP Companhia Urbanizadora Nova Capital do Brasil. Foram levantadas informações sobre área superficial do DF, clima, condições do solo, extensão de áreas de cultivo (agricultáveis), de áreas de exploração (áreas degradadas), além da existência de mercado para utilização do lodo como matéria prima em processos produtivos, entre outras.

Esses dados subsidiaram o levantamento das possibilidades de aplicação de lodos de esgotos tecnicamente adequadas para o Distrito Federal e, de acordo com os critérios de qualidade de lodos apresentados para cada alternativa, foram identificadas as concentrações e parâmetros recomendados no controle da qualidade dos lodos de esgotos, para os diversos usos. A Figura 4.4 mostra uma representação esquemática dos passos realizados para a elaboração dessa etapa. 


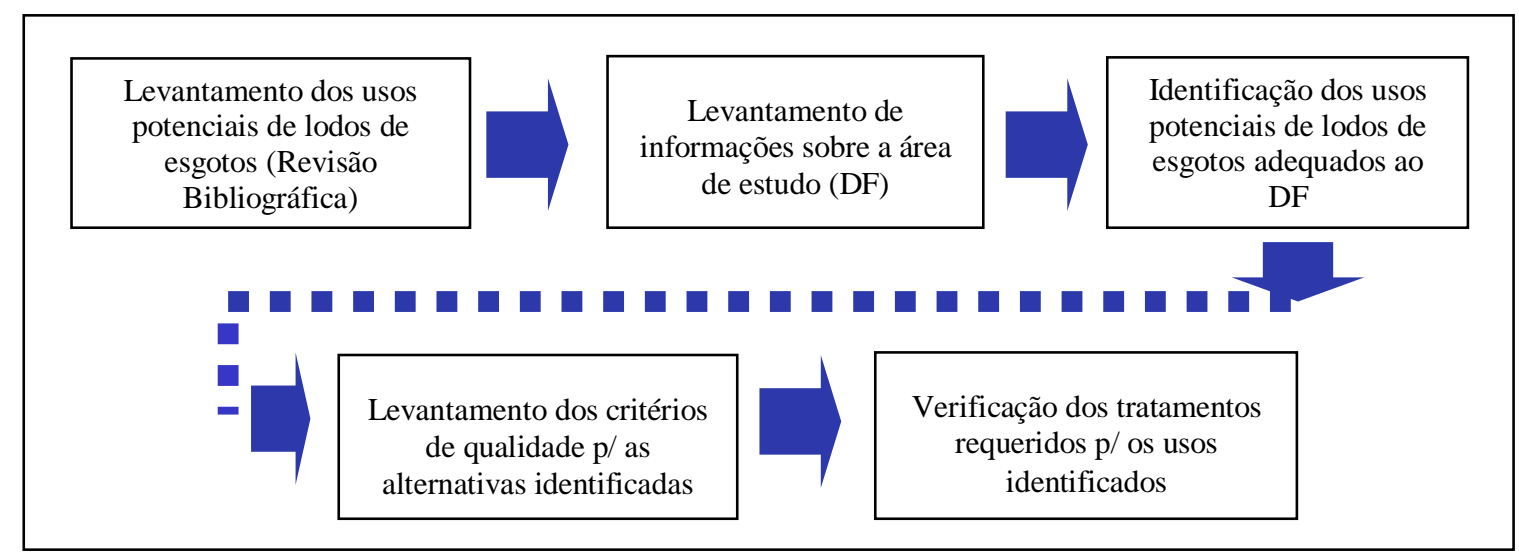

Figura 4.4 - Representação esquemática das etapas realizadas para a identificação das alternativas de manejo de lodo de esgotos

\subsection{COMPARAÇÃO E ANÁLISE DOS DADOS E RESULTADOS}

A averiguação das características dos lodos gerados e do desempenho das unidades de tratamento da fase sólida foi realizada a partir da análise estatística dos dados disponibilizados e confrontada com os requisitos necessários para as diferentes aplicações (processamento e destinação) de maneira a responder as seguintes proposições:

- os processos de tratamento de lodos adotados estão de acordo com o que é recomendado na literatura especializada?

os lodos gerados nas diversas etapas apresentam características médias que atendam aos requisitos de qualidade recomendados para os diferentes tipos de processamento?

os lodos de esgotos gerados no Distrito Federal atendem aos critérios de qualidade requeridos para os usos aplicáveis?

As comparações foram realizadas para se obter um leque variado de possíveis aplicações, possibilitando identificar tendências para a seleção das alternativas mais vantajosas, segundo critérios ambientais e técnicos. A questão econômico-financeira, apesar de reconhecidamente importante, não será objeto de discussão na presente pesquisa, mas deverá ser contemplada em estudos futuros, de maneira a integrar os conhecimentos adquiridos e compor um conjunto de alternativas técnica e ambientalmente aceitáveis, socialmente adequadas e viáveis economicamente.

Os dados levantados foram submetidos a tratamento estatístico. Para isso, foram calculadas as estatísticas descritivas relativas ao número de dados, médias, mediana, valores máximos e mínimos, amplitude (máximo - mínimo), quartis inferior e superior. 
Os dados de concentração afluente dos constituintes foram comparados aos valores reportados na literatura, de maneira a identificar a adequabilidade dos tratamentos empregados e sua correlação com a geração de lodos em cada estação.

Quanto à adequabilidade dos tratamentos, aos quais os diferentes tipos de lodo são submetidos, mais uma vez, foram realizadas análises descritivas por meio de gráficos da série temporal e gráficos Box-plot, elaborados com dados de amplitude (mínimo e máximo), médias e medianas e $1^{\circ}$ e $3^{\circ}$ quartis. Esses gráficos permitiram a visualização da variabilidade do comportamento do lodo ao longo das etapas de geração e tratamento da fase sólida. 


\section{APRESENTAÇÃO E ANÁLISE DE RESULTADOS}

\subsection{GESTÃO DE LODOS NAS ETES DO DISTRITO FEDERAL}

A primeira etapa metodológica deste trabalho consiste no diagnóstico do manejo de lodos atualmente empregados no Distrito Federal. Trata-se de uma descrição sucinta e simplificada das ETEs do Distrito Federal, objetivando o reconhecimento dos sistemas de tratamento existentes, identificando os processos de estabilização, condicionamento, desaguamento e higienização do lodo, bem como a produção de lodo e os procedimentos de disposição final, em vigor na concessionária de serviços de saneamento do Distrito Federal (CAESB).

Essas informações foram levantadas a partir de relatórios técnicos e operacionais, bem como a partir de visitas técnicas às áreas operacionais da companhia.

\subsubsection{Sistema de Tratamento de Esgotos no Distrito Federal}

A Companhia de Saneamento Ambiental do Distrito Federal - CAESB atua em toda a região do Distrito Federal. Segundo dados publicados no PDAD (CODEPLAN, 2011), a CAESB atende a uma população de 2,54 milhões de habitantes com serviços de abastecimento de água e 2,29 milhões com serviços de esgotamento sanitário, o que corresponde, respectivamente, a $99,47 \%$ e $89,7 \%$ da população regularmente instalada no Distrito Federal. Um dos índices mais significativos apresentados pela companhia é o de tratamento de esgotos que atingiu, em 2005, a marca de $100 \%$ de tratamento dos esgotos coletados.

Como reflexo do elevado índice de tratamento de esgotos, tem-se, por sua vez, uma maior geração de resíduos, em que se destaca a produção de lodos. Segundo informações da companhia, em 2012, foram produzidos cerca de 139.000 toneladas (base úmida), o que corresponde a cerca de 383 toneladas de lodo de esgotos gerados diariamente no Distrito Federal.

O sistema de tratamento de esgotos sanitários do Distrito Federal compreende um total de 16 estações de tratamento de esgotos (Tabela 5.1), distribuídas ao longo de quatro bacias 
hidrográficas: Bacia Lago Paranoá, Bacia São Bartolomeu, Bacia Rio Ponte Alta/ Alagado e Bacia Rio Descoberto/Melchior.

\subsubsection{Tecnologias de tratamento de esgotos em operação no Distrito Federal}

Os processos de tratamento empregados nas ETEs do Distrito Federal são constituídos pela combinação de diferentes tecnologias, de maneira a alcançar os níveis de remoção de matéria orgânica e nutrientes exigidos para cada corpo receptor. De maneira a facilitar a compreensão, a Tabela 5.1 ilustra essas combinações, bem como os dados de projeto e atuais, relativos à vazão e população atendida.

Foram acrescentadas ainda as informações de carga orgânica teórica, expressa em $\mathrm{kgDBO} / \mathrm{dia}$, calculada a partir da equação (5.1), e de população equivalente, obtida tendo como base a carga real de DBO registrada em 2013, para cada estação. O cálculo foi feito aplicando-se a equação (4.5). Essa informação foi utilizada posteriormente para o cálculo de produção teórica de lodo, cujos coeficientes de produção encontrados na literatura são expressos em termos de carga de sólidos por habitante.

$$
C O_{T E O ́ R I C A}=\frac{P_{p} \times C_{c}}{1000}
$$

Onde:

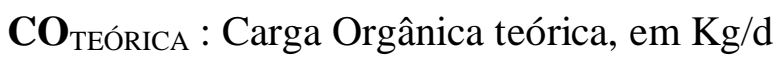

Cc: Coeficiente de contribuição per capita de DBO, 54gDBO/hab.dia

$\mathrm{P}_{\mathrm{p}}$ : População de projeto, habitante

$$
P_{e}=\frac{C O_{\text {aplicada }} \times 1000}{C_{c}}
$$

Onde:

$\mathbf{P}_{\mathrm{e}}$ : População equivalente, habitante

CO $_{\text {aplicada }}$ : Carga Orgânica afluente (2013), em Kg/d

$\mathrm{C}_{\mathrm{c}}$ : Coeficiente de contribuição per capita de $\mathrm{DBO}, 54 \mathrm{gDBO} / \mathrm{hab}$.dia

Na tabela 5.1 são apresentadas as informações obtidas a partir das determinações acima. 
Tabela 5.1 - Tecnologias de tratamento de esgotos aplicados nas ETEs do DF, População, Vazão e Carga Orgânica (real e de projeto)

\begin{tabular}{|c|c|c|c|c|c|c|c|c|c|}
\hline \multirow{2}{*}{$\begin{array}{c}\text { Bacia } \\
\text { Hidrográfica }\end{array}$} & \multirow{2}{*}{$\begin{array}{l}\text { Estações de } \\
\text { Tratamento de } \\
\text { Esgotos do DF }\end{array}$} & \multirow{2}{*}{$\begin{array}{c}\text { Tecnologia de tratamento } \\
\text { empregada }\end{array}$} & \multicolumn{2}{|c|}{ População atendida (hab) } & \multicolumn{2}{|c|}{$\begin{array}{l}\text { Vazão média de } \\
\text { Esgotos (L/s) }\end{array}$} & \multirow{2}{*}{$\begin{array}{c}\text { Carga } \\
\text { Projeto } \\
\text { (kg } \\
\text { DBO/dia) }\end{array}$} & \multirow{2}{*}{$\begin{array}{c}\text { Carga média } \\
\text { anual }(2013) \\
(\mathrm{kg} \mathrm{DBO} / \mathrm{d})\end{array}$} & \multirow{2}{*}{$\begin{array}{c}\text { Pop } \\
\text { equivalente } \\
\left(n^{0} \text { hab }\right)\end{array}$} \\
\hline & & & Projeto & Atual & Projeto & $\begin{array}{l}\text { Atual } \\
\text { (média } \\
\text { anual) }\end{array}$ & & & \\
\hline \multirow{4}{*}{ 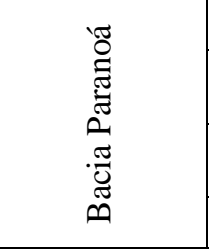 } & ETE BRASÍLIA SUL & RBN + POLIMENTO FINAL & 460.000 & 487.628 & 1.500 & 1.100 & 24.840 & 32.240 & 597.040 \\
\hline & $\begin{array}{l}\text { ETE BRASÍLIA } \\
\text { NORTE }\end{array}$ & RBN + POLIMENTO FINAL & 250.000 & 163.494 & 920 & 479 & 13.500 & 13.042 & 241.523 \\
\hline & $\begin{array}{l}\text { ETE RIACHO } \\
\text { FUNDO }\end{array}$ & RBNB & 43.000 & 34.055 & 94 & 48 & 2.322 & 2.155 & 39.910 \\
\hline & ETE TORTO & RAFA + INFIL+ CLORAÇÃO & 2.500 & 1.226 & 6 & 3 & 135 & 119 & 2.198 \\
\hline \multirow{5}{*}{ 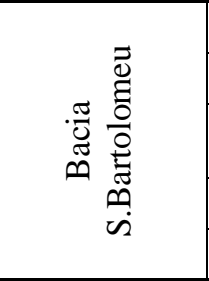 } & ETE SOBRADINHO & LODO ATV.+ TRAT. QUÍM. & 40.000 & 83.699 & 56 & 99 & 2.160 & 3.762 & 69.670 \\
\hline & ETE PLANALTINA & RAFA / LF+ LM & 138.000 & 114.437 & 255 & 98 & 7.452 & 5.487 & 101.617 \\
\hline & $\begin{array}{l}\text { ETE V. } \\
\text { AMANHECER }\end{array}$ & $\mathrm{RAFA}+\mathrm{LAF}+\mathrm{LM}$ & 15.000 & 19.834 & 35 & 14 & 810 & 815 & 15.096 \\
\hline & ETE PARANOÁ & RAFA + LAT & 60.000 & 96.215 & 112 & 64 & 3.240 & 4.170 & 77.219 \\
\hline & ETE S.SEBASTIÃO & $\mathrm{RAFA}+\mathrm{ES}+\mathrm{LM}$ & 77.800 & 75.817 & 226 & 121 & 4.201 & 5.864 & 108.598 \\
\hline \multirow{4}{*}{ 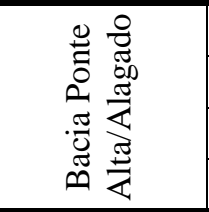 } & ETE GAMA & RAFA + RB + CLARIFICADOR & 182.630 & 121.509 & 328 & 197 & 9.862 & 6.153 & 113.943 \\
\hline & ETE S. MARIA & $\mathrm{RAFA}+\mathrm{LAT}+\mathrm{ES}+\mathrm{PF}$ & 84.852 & 41.771 & 154 & 43 & 4.582 & 2.961 & 54.835 \\
\hline & ETE ALAGADO & RAFA + LAT+ ES+ PF & 84.852 & 77.673 & 154 & 76 & 4.582 & 5.300 & 98.150 \\
\hline & ETE REC. EMAS & RAFA + LAMC + LAF & 125.500 & 160.978 & 246 & 137 & 6.777 & 8.374 & 155.081 \\
\hline \multirow{3}{*}{ 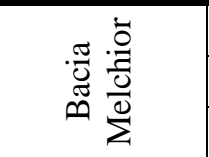 } & ETE SAMAMBAIA & $\mathrm{RAFA} / \mathrm{LF}+\mathrm{LAT}+\mathrm{LP}+\mathrm{PF}$ & 180.000 & 191.818 & 284 & 261 & 9.720 & 17.822 & 330.030 \\
\hline & ETE MELCHIOR & RAFA + UNITANK & 896.799 & 577.031 & 1.469 & 885 & 48.427 & 25.149 & 465.718 \\
\hline & ETE BRAZLÂNDIA & L.An + LF & 29.600 & 44.629 & 87 & 41 & 1.598 & 2.502 & 46.334 \\
\hline
\end{tabular}

Fonte: Adaptado de CODEPLAN (2011); SIESG (2013) e Relatório Operacional POE/DP/CAESB (2013).

Legenda:

RBN - Remoção Biológica de Nutrientes

RBNB - Remoção Biológica de Nutrientes por Batelada

RAFA - Reator Anaeróbio de Fluxo Ascendente

INFIL - Infiltração

L.An - Lagoa anaeróbia

LAF - Lagoa Aerada facultativa

RB - Reator Biológico

ES - Escoamento superficial
LAMC - Lagoa Aerada de Mistura Completa

LAT - Lagoa de Alta Taxa
LF - Lagoa facultativa

LM - Lagoa de Maturação

LP - Lagoa de Polimento

UNITANK - Reator Aeróbio 
Segundo o que pode ser observado na Tabela 5.1, considerando a carga hidráulica de projeto, à exceção da ETE Sobradinho, as estações de modo geral apresentam folga hidráulica. Entretanto, os dados de concentração de $\mathrm{DBO}_{5}$ dos esgotos afluentes, ano base 2013, demonstram que as ETEs do DF recebem atualmente uma carga próxima à estimada e em 50\% das estações a carga orgânica afluente supera o previsto em projeto, são elas: Brasília Sul, Sobradinho, Paranoá, São Sebastião, Alagado, Recanto das Emas, Samambaia e Brazlândia.

Uma das justificativas possíveis para essa condição reside no uso, por ocasião do projeto das estações, de coeficientes de contribuição per capita de esgotos mais elevados. Ao longo dos anos os projetistas da CAESB vêm corrigindo esses valores, razão pela qual se observa um afastamento menor entre as vazões estimadas e reais para as estações mais novas, caso das ETEs Melchior, Gama e Santa Maria.

Quanto à carga orgânica afluente, dois fatores podem ser considerados para explicar a condição verificada, ambos provocando o efeito de elevação de carga orgânica identificado: um refere-se à chamada população flutuante, caracterizada pelo afluxo de pessoas aos grandes centros comerciais e administrativos, que ocorre normalmente nos dias úteis e em horário comercial. Essa condição define um hidrograma distinto entre as estações de tratamento de esgotos no Distrito Federal, em que os volumes de esgotos afluentes são maiores ao longo do dia e nos dias úteis, diminuindo drasticamente nos finais de semanas e nos períodos noturnos. Já nas cidades, denominadas dormitórios, essa condição se inverte, com picos de vazão no período noturno e volumes maiores de esgotos afluentes nos finais de semana.

O outro fator a ser mencionado é a condição socioeconômica da população, pois essa também influencia as concentrações de matéria orgânica nos esgotos, visto que nas regiões de menor poder aquisitivo o consumo de água per capita é bem inferior, gerando, em consequência, um esgoto com concentrações mais elevadas de contaminantes, caso, por exemplo, da ETE Paranoá.

Os processos de tratamento e suas peculiaridades são descritos a seguir: 


\section{I - Tratamento preliminar}

Em todas as ETEs do Distrito Federal, o tratamento dos esgotos inicia-se pelo tratamento preliminar - gradeamento e desarenação - mecanizado, à exceção da ETE Torto, para remoção de sólidos grosseiros e areia. Os resíduos gerados nessa etapa, denominados detritos, são dispostos em aterro controlado, sem passar por nenhum processo adicional de inertização.

A eficiência do tratamento preliminar é de fundamental importância para a minimização de problemas operacionais, sejam quais forem as tecnologias empregadas nas etapas subsequentes, isso porque a acumulação de sólidos não biodegradáveis no sistema pode provocar o desgaste excessivo e constantes obstruções de tubulações e equipamentos, formação de zonas mortas e de caminhos preferenciais nos tanques, além da diminuição significativa do volume de biomassa no sistema.

De acordo com estudos realizados por Ramos (2008), das 11 ETEs do DF que utilizam reatores anaeróbios (UASB), 50\% apresentam ineficiência da etapa de tratamento preliminar. Nessa pesquisa, o autor aponta como principais causas do funcionamento inadequado do tratamento preliminar a confiabilidade dos equipamentos e os problemas hidráulicos nas unidades.

Segundo informações obtidas por meio do levantamento realizado junto às unidades operacionais, que compreendeu as 16 estações do DF, algumas melhorias foram introduzidas em diversas estações desde aquela época.

As estações Brasília Sul, Brasília Norte, Paranoá e Sobradinho tiveram seus gradeamentos substituídos por peneiras, passando de um espaçamento de $15 \mathrm{~mm}$ para $6 \mathrm{~mm}$. Isso proporcionou um aumento na eficiência de remoção de sólidos grosseiros. Os desarenadores das ETEs Paranoá e Sobradinho também foram reformados. Além disso, estão em andamento alterações no sistema de lavagem de areia das estações Brasília Sul e Brasília Norte.

A remoção de areia, entretanto, continua sendo um problema na maioria das unidades, pois os problemas hidráulicos citados por Ramos (2008) ainda não foram completamente solucionados; por essa razão, ainda ocorre a deposição de areia nos canais e o aporte de areia nas unidades subsequentes. 
Dessa forma, as dificuldades mencionadas no referido estudo também foram identificadas nos levantamentos realizados na presente pesquisa, com relatos de problemas por ocasião das intervenções de manutenção na operação de esvaziamento dos reatores, devido à presença acentuada de areia e de material grosseiro não removido no tratamento preliminar, dificultando as ações de limpeza com o emprego de bombas, caminhões limpafossa, dentre outros.

A Tabela 5.2 apresenta a produção de areia, em valores absolutos e relativos, por estação de tratamento de esgotos, referentes ao ano de 2013. Conforme pode ser observado, a maior produção absoluta de areia corresponde à ETE Brasília Sul, seguida da ETE Brasília Norte, ETE Melchior e ETE São Sebastião, enquanto a menor produção foi verificada na ETE Vale do Amanhecer, sendo que as ETEs Brazlândia e Torto não reportaram os valores removidos em 2013. Quanto à produção relativa, observa-se que o comportamento dos sistemas de desarenação apresentam maior similaridade.

Tabela 5.2 - Produção absoluta de areia das ETEs do Distrito Federal - ano 2013

\begin{tabular}{lccc}
\hline \multirow{2}{*}{ ETES } & \multicolumn{3}{c}{ Volume de areia } \\
\cline { 2 - 4 } & $\left(\mathrm{m}^{3}\right)$ & $\left(\mathrm{m}^{3}\right.$ areia $/ \mathrm{m}^{3}$ esgoto tratado $)$ & $9, \mathrm{~m}^{3}$ esgoto tratado $)$ \\
\hline \hline ETE BRASÍLIA SUL & 3.264 & $9,8 \mathrm{E}-05$ & 98 \\
\hline ETE BRASÍLIA NORTE & 1.028 & $6,8 \mathrm{E}-05$ & 68 \\
\hline ETE ALAGADO & 212 & $7,6 \mathrm{E}-05$ & 76 \\
\hline ETE GAMA & 335 & $5,1 \mathrm{E}-05$ & 23 \\
\hline ETE RECANTO & 117 & $2,3 \mathrm{E}-05$ & 23 \\
\hline ETE MELCHIOR & 618 & $2,3 \mathrm{E}-05$ & 130 \\
\hline ETE SOBRADINHO & 381 & $13 \mathrm{E}-05$ & 110 \\
\hline ETE PARANOÁ & 279 & $11 \mathrm{E}-05$ & 83 \\
\hline ETE RIACHO FUNDO & 133 & $8,3 \mathrm{E}-05$ & 120 \\
\hline ETE S.SEBASTIÃO & 467 & $12 \mathrm{E}-05$ & $\mathrm{NI}$ \\
\hline ETE STA MARIA & 142 & $9,4 \mathrm{E}-05$ & 33 \\
\hline ETE BRAZLÂNDIA & $\mathrm{NI}$ & $\mathrm{NI}$ & 62 \\
\hline ETE VALE DO AMANHECER & 21 & $3,3 \mathrm{E}-05$ & 10 \\
\hline PLANALTINA & 227 & $6,2 \mathrm{E}-05$ & $\mathrm{NI}$ \\
\hline SAMAMBAIA & 122 & $1,0 \mathrm{E}-05$ & $\mathrm{NI}$ \\
\hline TORTO & $\mathrm{NI}$ & & 23 \\
\hline
\end{tabular}

Nota: NI - Não informado

Quando analisadas as diferenças encontradas, tanto no caso da produção absoluta quanto relativa, algumas hipóteses podem ser levantadas para explicar essa variabilidade, entre elas estão:

o estado de conservação e tipo de material das redes coletoras; 
- a baixa eficiência do sistema de remoção de areia (roscas transportadoras e lavadoras de areia), reportado pelos operadores dos sistemas por ocasião das visitas técnicas;

as condições hidráulicas que favorecem a deposição de areia ao longo dos canais afluentes; e

as características das bacias de contribuição, tais como: perfil sócioeconômico da população, atendimento com coleta de águas pluviais, entre outros.

\section{II - Tratamento Primário}

Na etapa seguinte é realizada a redução de carga orgânica, por meio da decantação primária ou por processo anaeróbio - reatores UASB. É a primeira fase onde se tem a geração de lodo. As estações que contam com decantação primária, estações Brasília Norte, Brasília Sul e Sobradinho, dão origem ao lodo primário ou lodo bruto; já nas unidades onde o tratamento empregado são os reatores anaeróbios, caso de outras 11 estações, tem-se a formação de lodo anaeróbio estabilizado.

As estações Brasília Sul e Brasília Norte operam com decantadores primários circulares, dotados de pontes raspadoras e com descarte automatizado de lodo de fundo. De acordo com informações dos operadores do sistema, os intervalos entre os descartes, bem como o tempo de abertura das válvulas de fundo (que determina o volume a ser descartado) são rotinas definidas segundo o histórico de operação da unidade e considerando o desempenho dos adensadores por gravidade, para onde esse lodo é enviado.

Os resultados de eficiência operacional do tratamento primário nessas estações, em termos de remoções observadas na fase líquida, mostram-se aquém do esperado. Isso ocorre, principalmente, devido a um problema com a representatividade da amostragem realizada, que não compreende os vários reciclos internos que adentram a fase antes dos decantadores, bem como a interferência no ponto de amostragem à jusante, que amostra o efluente depois de receber o clarificado dos adensadores.

A ETE Sobradinho mencionada acima entrou em operação em 1967, utilizando a tecnologia de lodos ativados. Segundo dados de projeto, a estação tratava uma vazão de esgotos cerca de 30\% acima de sua capacidade (SIESG, 2013). Por essa razão, desde 1993, havia sido introduzida em seu fluxo de processo, a adição de produto químico na etapa de 
tratamento primário, com o uso de sulfato de alumínio, de maneira a compensar as deficiências de remoção em função da sobrecarga da estação.

A literatura especializada aponta que o tratamento primário quimicamente assistido, provoca um aumento na geração do lodo, além de onerar os custos operacionais. No caso da ETE Sobradinho foram verificados reflexos no tratamento da fase sólida, com um impacto direto sobre o tempo de digestão anaeróbia, uma vez que o volume de lodo primário produzido sofreu um acréscimo e as unidades de digestão de lodo não haviam sido ampliadas.

As estações de tratamento de esgotos do Distrito Federal cuja configuração apresenta unidades de tratamento primário caracterizado por reatores anaeróbios de fluxo ascendente e manta de lodo apresentam algumas peculiaridades entre si. São elas: ETE Samambaia, ETE Planaltina, ETE Santa Maria, ETE Alagado, ETE Recanto das Emas, ETE Melchior, ETE Gama, ETE Paranoá, ETE São Sebastião, ETE Vale do Amanhecer e ETE Torto.

As estações de Samambaia e Planaltina compreendem reatores anaeróbios seguidos de lagoas facultativas geminadas, nessas unidades o lodo se acumula no reator e quando o seu volume ultrapassa a capacidade de armazenamento, esse lodo é perdido para as células facultativas adjacentes.

As estações Santa Maria, Alagado e Recanto das Emas tiveram seus reatores anaeróbios modificados após a sua implantação e, devido a dificuldades para remoção de escuma nos compartimentos do separador trifásico, recentemente foram realizadas adequações dos dispositivos separadores, de maneira a permitir uma saída contínua da escuma, o que leva a uma maior perda de sólidos pelo efluente. Essas alterações ainda estão sendo avaliadas.

As ETEs Vale do Amanhecer e Torto são unidades compactas, que atendem a uma demanda localizada, a remoção de lodo nos reatores anaeróbios dessas unidades é uma operação eventual, realizada com o uso de caminhões limpa-fossa, portanto, não seguem um procedimento sistematizado. Ademais, está em andamento o processo de desativação da ETE Torto, seus efluentes serão encaminhados, via bombeamento, para a estação Brasília Norte.

As estações Gama e Melchior foram as últimas unidades a serem implantadas no Distrito Federal e contam com 8 anos de operação. Essas unidades, entretanto, já apresentam 
diversos problemas estruturais relacionados à corrosão, rompimentos de separadores de fase, escape de gases e acúmulo excessivo de escuma em suas unidades.

A ETE Paranoá e São Sebastião são unidades cujos reatores anaeróbios apresentam a última configuração adotada pela CAESB, entretanto, enquanto essa última necessita reparos das estruturas de seus reatores, a ETE Paranoá conta com unidades recuperadas recentemente e opera em condições estáveis.

O gerenciamento do descarte de lodo em reatores UASB é uma das mais importantes rotinas operacionais nesse sistema de tratamento. A retirada de lodo excedente com a frequência adequada pode evitar uma maior perda de sólidos para o compartimento de decantação. Em contrapartida, a não retirada pode elevar a taxa de produção de escuma e conduzir a uma deterioração do efluente final (Lobato et al., 2007).

A definição do ponto de descarte de lodo, frequência e quantidade a ser removida é determinante para se obter um efluente com qualidade, entretanto, também influencia, em grande medida, as estratégias de manejo de lodo das estações, uma vez que os volumes de lodo descartado, bem como sua concentração, deverão ser considerados na operação das unidades subsequentes, tais como: lagoas de lodo, leitos de secagem e equipamentos para desaguamento mecanizado (Chernicharo, 2007)

Segundo Chernicharo (2007), para se estabelecer estratégias de descarte de lodo dos reatores UASB seria interessante proceder à amostragem do lodo do reator, o que possibilitaria determinar o perfil de sólidos e a atividade metanogênica específica da biomassa.

Nas unidades do Distrito Federal tanto o levantamento atual quanto os estudos realizados por Ramos (2008), apontaram que nas diversas ETEs que empregam o Reator UASB não há qualquer controle do crescimento da manta de lodo, as estratégias de descarte de lodo fundamentam-se em observações empíricas e na conveniência operacional relacionada à disponibilidade de espaço para armazenamento e processamento do lodo.

Não foram identificadas rotinas definidas para os descartes de lodo e, segundo informações levantadas junto aos operadores dos sistemas, problemas no tocante ao espessamento da camada de escuma ocorrem com frequência. 


\section{III - Tratamento Secundário}

Em uma etapa posterior, com vistas a atingir o nível de remoção requerido, o efluente é submetido a um tratamento complementar; as lagoas de estabilização combinadas ou não com a disposição no solo têm sido as alternativas empregadas no Distrito Federal.

Nas ETEs de Samambaia, Alagado, Santa Maria, Recanto das Emas, Planaltina, Paranoá, São Sebastião e Vale do Amanhecer o lodo gerado é considerado lodo anaeróbio estabilizado. Não foram identificadas, por ocasião das visitas técnicas, rotinas sistematizadas de limpezas das lagoas. Apenas na ETE Paranoá, onde estão em operação nove lagoas de alta taxa, três delas operando em paralelo para cada reator UASB, existe um procedimento pré-estabelecido para remoção de lodo. Segundo levantamento, a cada ano três lagoas, uma de cada reator, são retiradas de carga no período de estiagem e, após a secagem natural, o lodo de fundo é removido com o auxílio de retroescavadeira e caminhões basculantes. O lodo retirado nessa operação é transportado para o pátio de estocagem da ETE Brasília Norte e de lá para o destino final.

\section{IV - Tratamento Terciário}

Para aquelas estações, cuja concepção prevê a remoção de matéria orgânica e nutrientes a nível terciário, o efluente é submetido a processos biológicos predominantemente aeróbios. O processo biológico de lodos ativados, com a configuração "Bardenpho modificado" ou Phoredox, tem sido adotado como alternativa tecnológica nas ETEs do Distrito Federal.

Nesse processo, os micro-organismos responsáveis pelo tratamento dos esgotos são mantidos em suspensão em tanques, chamados reatores biológicos, que garantem condições ideais para a promoção das reações bioquímicas, necessárias à degradação da matéria orgânica e à remoção de nutrientes.

Na sequência, a biomassa ativa é separada do líquido tratado, mediante processo de sedimentação realizado nos clarificadores ou decantadores secundários, retornando, então, aos reatores para continuação do tratamento. Ao longo do processo há um crescimento bacteriano que resulta em uma elevada produção de lodo, que é descartada do sistema a partir do controle da idade de lodo. O lodo originado nessa etapa é denominado lodo aeróbio, que pode ser estabilizado, caso da aeração prolongada, ou não estabilizado quando apresenta baixa idade de lodo. 
O tratamento de esgotos empregado na ETE Sobradinho é o lodo ativado convencional, entretanto, devido à adição de produtos químicos à etapa de tratamento primário, mencionada anteriormente, a estação elevou significativamente a remoção de fósforo total. Por essa razão, tendo em vista a combinação do tratamento primário quimicamente assistido e lodos ativados convencional, o processo pode ser classificado como de nível terciário.

As estações Brasília Sul e Brasília Norte são unidades implantadas em uma região adensada da cidade de Brasília e têm como corpo receptor o Lago Paranoá. Essas unidades, que antes empregavam o tratamento de lodos ativados convencional, tiveram seus processos adequados de maneira a promover a remoção de nutrientes, com vistas à preservação do lago contra o processo de eutrofização. Essa importante melhoria também trouxe o inconveniente de aumentar significativamente a produção de lodo, que já era elevada, do sistema.

As unidades Gama e Melchior foram projetadas combinando o tratamento anaeróbio, reator UASB, e a tecnologia de lodos ativados por aeração prolongada. Os níveis de tratamento esperados para ambas era o mesmo, entretanto, apenas a estação Gama vem atendendo às remoções de projeto. A ETE Melchior ainda apresenta algumas instabilidades no processo operacional, ligadas principalmente, às operações no reator aeróbio, denominado UNITANK. Esse reator é uma variante dos reatores biológicos empregados nas estações da CAESB, constituído de três tanques, o maior deles atuando na fase aeróbia/anóxica e os dois restantes trabalhando nas fases anaeróbia, aeróbia/anóxica e zona de reaeração, de forma alternada, obedecendo a uma matriz de operação pré-estabelecida.

\section{V - Tratamento Avançado}

Complementarmente ao tratamento biológico, é empregada, em algumas estações, a etapa de tratamento avançado. O processo empregado nessas estações é denominado polimento químico e consiste basicamente do uso das técnicas de coagulação com sulfato de alumínio (ou cloreto férrico), floculação e flotação por ar dissolvido. Nessa etapa os sólidos e fósforo residuais do tratamento biológico são retidos por meio da floculação com produtos químicos e separados por flotação. Os sólidos separados são recolhidos por raspadores de superfície e originam o chamado lodo químico, que é encaminhado à etapa de tratamento da fase sólida. Após isso, o efluente tratado segue para o corpo receptor. 


\subsubsection{Características dos esgotos afluentes às estações de tratamentos de esgotos do Distrito Federal}

No Distrito Federal, o sistema coletor de esgotos adotado é o denominado separador absoluto, ou seja, aquele concebido para coleta somente das águas residuárias, a coleta de águas pluviais é realizada por sistema específico para esse fim. Não nenhum pólo industrial expressivo no Distrito Federal, comparado aos grandes centros urbanos, assim, a característica predominante é de esgotos domésticos, ou esgotos urbanos, uma vez que não há separação entre esgotos hospitalares, comerciais e do setor de serviços.

O conhecimento das concentrações afluentes às ETEs, no presente estudo, tem relevância justificada pelo impacto que causa à quantidade de lodo gerado, visto que as estimativas de volumes de lodos são realizadas considerando as cargas orgânicas afluentes as estações de tratamento de esgotos e as eficiências de remoções esperadas nos processos de tratamento de esgotos empregados.

Foram disponibilizados dados de concentrações dos principais parâmetros de controle dos esgotos afluentes às ETEs do Distrito Federal, à saber DBO, DQO, SS, TKN e P-total, entre os anos de 2004 e 2013. Esses dados foram analisados por meio de estudos estatísticos preliminares, visando o conhecimento e caracterização dos esgotos afluentes comparados com os valores usuais reportados pela literatura (Tabela 5.3). Foram levantados os números de dados calculados e calculadas as médias, mediana, valores máximos e mínimos e desvio padrão, esses dados são apresentados na Tabela 5.4 e nas Figuras 5.1 a 5.5. As ETEs foram agrupadas por tecnologias de tratamento similares.

Tabela 5.3 - Concentrações usuais para esgotos domésticos afluentes, reportados na literatura

\begin{tabular}{|c|c|c|}
\hline \multirow{2}{*}{ Parâmetros } & \multicolumn{2}{|c|}{ Concentrações reportadas na literatura } \\
\cline { 2 - 3 } & Faixa & Típica \\
\hline \hline DQO & $400-800$ & 700 \\
\hline DBO & $200-500$ & 350 \\
\hline SS & $200-450$ & 400 \\
\hline TKN & $35-75$ & 50 \\
\hline P-total & $4-15$ & 7 \\
\hline
\end{tabular}

Fonte: adaptado de von Sperling (2005)

Na Tabela 5.4 estão resumidas as estatísticas descritivas básicas referentes às estações de tratamento de esgotos agrupadas por tratamentos similares, ao longo dos anos de 2004 a 2013. 
Tabela 5.4 - Estatística descritiva referente às concentrações de esgotos afluentes às ETEs do Distrito Federal, agrupados por tecnologias de

\begin{tabular}{|c|c|c|c|c|c|c|c|c|c|c|c|c|c|c|c|c|c|}
\hline \multirow{2}{*}{ 离 } & \multirow{2}{*}{ 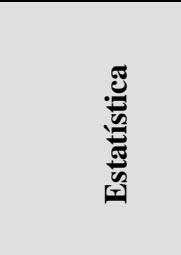 } & \multicolumn{3}{|c|}{ LA - Bardenpho } & \multicolumn{5}{|c|}{ RAFA + La } & \multicolumn{3}{|c|}{ RAFA + La + PF } & \multicolumn{2}{|c|}{ RAFA + Rb } & \multirow{2}{*}{ 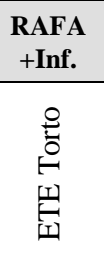 } & \multirow{2}{*}{ 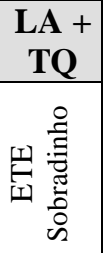 } & \multirow{2}{*}{ 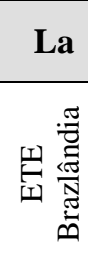 } \\
\hline & & 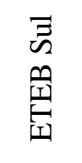 & 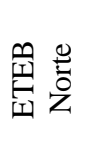 & 荘总 & 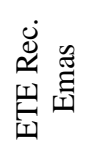 & 岾 $\frac{\stackrel{\Xi}{\Xi}}{\stackrel{\Xi}{\Xi}}$ & 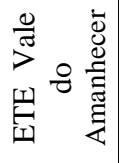 & 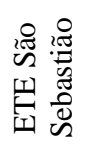 & 四 & 四 & 四总 & 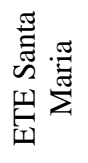 & 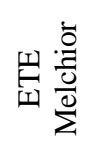 & 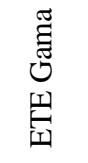 & & & \\
\hline \multirow{6}{*}{ DQO } & $\mathrm{N}^{\circ}$ de dados & 801 & 846 & 612 & 301 & 322 & 306 & 323 & 320 & 241 & 334 & 190 & 717 & 2580 & 166 & 521 & 231 \\
\hline & Média & 534 & 496 & 725 & 996 & 937 & 906 & 774 & 1170 & 674 & 1011 & 972 & 585 & 729 & 937 & 575 & 873 \\
\hline & Mín & 217 & 156 & 117 & 469 & 413 & 321 & 261 & 260 & 309 & 242 & 423 & 203 & 283 & 268 & 200 & 312 \\
\hline & Máx & 1557 & 962 & 1792 & 1700 & 1674 & 1689 & 1601 & 1350 & 1352 & 1890 & 1911 & 1813 & 1820 & 1790 & 1405 & 1672 \\
\hline & Mediana & 515 & 490 & 711 & 994 & 936 & 882 & 739 & 1174 & 651 & 991 & 941 & 580 & 701 & 914 & 602 & 865 \\
\hline & Desv.padrão & 157 & 100 & 219 & 209 & 196 & 287 & 255 & 245 & 194 & 235 & 245 & 170 & 232 & 342 & 273 & 253 \\
\hline \multirow{6}{*}{ DBO } & $\mathrm{N}^{\circ}$ de dados & 330 & 314 & 327 & 260 & 320 & 301 & 307 & 303 & 231 & 331 & 197 & 447 & 394 & 163 & 333 & 224 \\
\hline & Média & 292 & 310 & 453 & 526 & 566 & 566 & 461 & 687 & 474 & 577 & 589 & 372 & 409 & 515 & 461 & 624 \\
\hline & Mín/ & 100 & 108 & 120 & 260 & 200 & 160 & 210 & 260 & 198 & 240 & 300 & 150 & 200 & 100 & 180 & 200 \\
\hline & Máx & 840 & 500 & 1500 & 840 & 963 & 1012 & 980 & 1350 & 840 & 1150 & 980 & 100 & 960 & 1000 & 950 & 750 \\
\hline & Mediana & 288 & 310 & 440 & 500 & 570 & 560 & 450 & 716 & 463 & 550 & 580 & 380 & 400 & 480 & 450 & 620 \\
\hline & Desv.padrão & 82 & 75 & 152 & 122 & 151 & 196 & 139 & 196 & 130 & 235 & 156 & 102 & 111 & 193 & 123 & 171 \\
\hline \multirow{6}{*}{ SS } & $\mathrm{N}^{\circ}$ de dados & 844 & 895 & 651 & 387 & 342 & 328 & 302 & 339 & 252 & 427 & 258 & 733 & 749 & 177 & 378 & 242 \\
\hline & Média & 208 & 208 & 232 & 374 & 397 & 462 & 335 & 488 & 299 & 423 & 411 & 252 & 255 & 327 & 320 & 388 \\
\hline & Mín/ & 48 & 60 & 70 & 108 & 152 & 81 & 136 & 242 & 96 & 70 & 203 & 100 & 100 & 70 & 117 & 144 \\
\hline & Máx & 966 & 602 & 1556 & 823 & 856 & 1044 & 986 & 1140 & 647 & 1250 & 787 & 675 & 550 & 976 & 730 & 775 \\
\hline & Mediana & 198 & 200 & 214 & 370 & 388 & 432 & 298 & 479 & 289 & 410 & 390 & 247 & 253 & 302 & 310 & 377 \\
\hline & Desv.padrão & 74 & 72 & 116 & 3,43 & 102 & 183 & 154 & 109 & 101 & 123 & 120 & 67 & 70 & 152 & 89 & 109 \\
\hline \multirow{6}{*}{ TKN } & $\mathrm{N}^{\circ}$ de dados & 803 & 889 & 609 & 279 & 279 & 285 & 345 & 338 & 247 & 318 & 194 & 620 & 565 & 177 & 369 & 227 \\
\hline & Média & 46 & 52 & 56 & 89 & 77 & 79 & 65 & 98 & 62 & 100 & 86 & 56 & 58 & 126 & 62 & 104 \\
\hline & Mín & 16 & 34 & 25 & 39 & 44 & 33 & 32 & 54 & 25 & 29 & 22 & 18 & 22 & 56 & 21 & 31 \\
\hline & Máx & 73 & 80 & 223 & 163 & 180 & 149 & 147 & 174 & 107 & 203 & 153 & 94 & 118 & 233 & 135 & 180 \\
\hline & Mediana & 46 & 52 & 55 & 89 & 77 & 77 & 62 & 97 & 62 & 98 & 80 & 56 & 57 & 127 & 63 & 102 \\
\hline & Desv.padrão & 8 & 6 & 14 & 19 & 14 & 21 & 16 & 15 & 14 & 32 & 27 & 13 & 13 & 31 & 12 & 39 \\
\hline \multirow{6}{*}{ P-total } & $\mathrm{N}^{\circ}$ de dados & 801 & 853 & 619 & 327 & 300 & 304 & 343 & 323 & 270 & 409 & 229 & 744 & 705 & 169 & 359 & 245 \\
\hline & Média & 6,2 & 6,5 & 7,8 & 12 & 10 & 10,3 & 9 & 12,4 & 9 & 14,3 & 12 & 8 & 9,08 & 14,4 & 8 & 13 \\
\hline & Mín/ & 2,3 & 3,14 & 2,9 & 4,8 & 4,4 & 4 & 3 & 5 & 4 & 5 & 4 & 3 & 4 & 3 & 4 & 6 \\
\hline & Máx & 15,8 & 14,8 & 64 & 29 & 15,9 & 22 & 28 & 24 & 20 & 32 & 14 & 23 & 33 & 28 & 16 & 28 \\
\hline & Mediana & 6,1 & 6,4 & 7,45 & 11,5 & 9,9 & 10 & 8 & 12 & 9 & 14 & 12 & 8 & 8 & 14 & 8 & 13 \\
\hline & Desv.padrão & 1,5 & 1,34 & 3,44 & 3,4 & 2,2 & 3,3 & 3,1 & 2,9 & 3 & 4,5 & 4,25 & 2 & 3,58 & 4,5 & 1,8 & 5 \\
\hline
\end{tabular}

Legenda: DBO - Demanda bioquímica de oxigênio $\quad$ DQO - Demanda química de oxigênio $\quad$ TKN - Nitrogênio Kjeldahl $\quad$ SS - Sólidos em suspensão $\quad$ P-total - Fósforo total Fonte: CAESB 


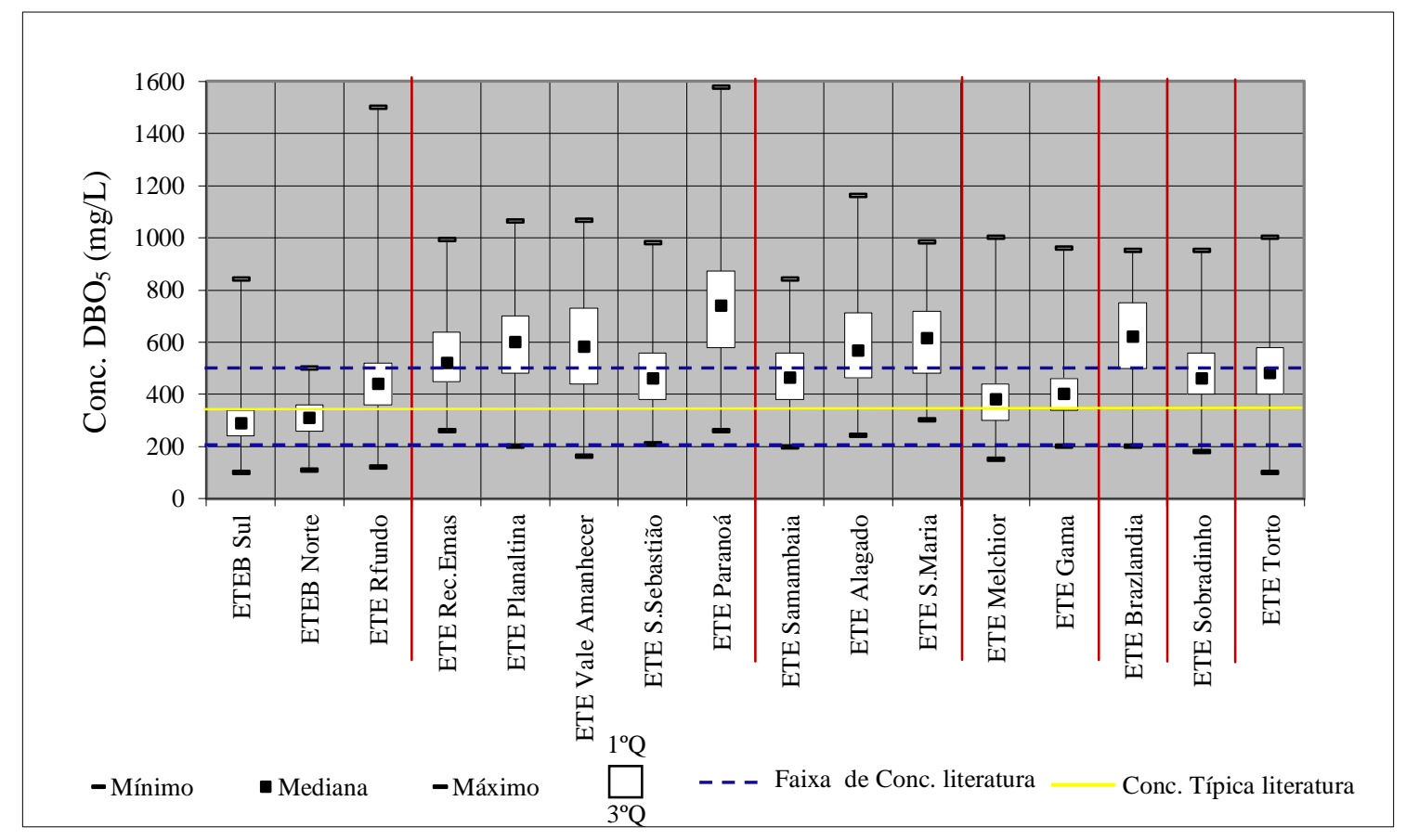

Figura 5.1 - Concentrações dos esgotos afluentes às ETEs do DF, agrupadas por tecnologias de tratamento de esgotos similares - parâmetro $\mathrm{DBO}_{5}(\mathrm{mg} / \mathrm{L})$ - entre anos $2004-2013$

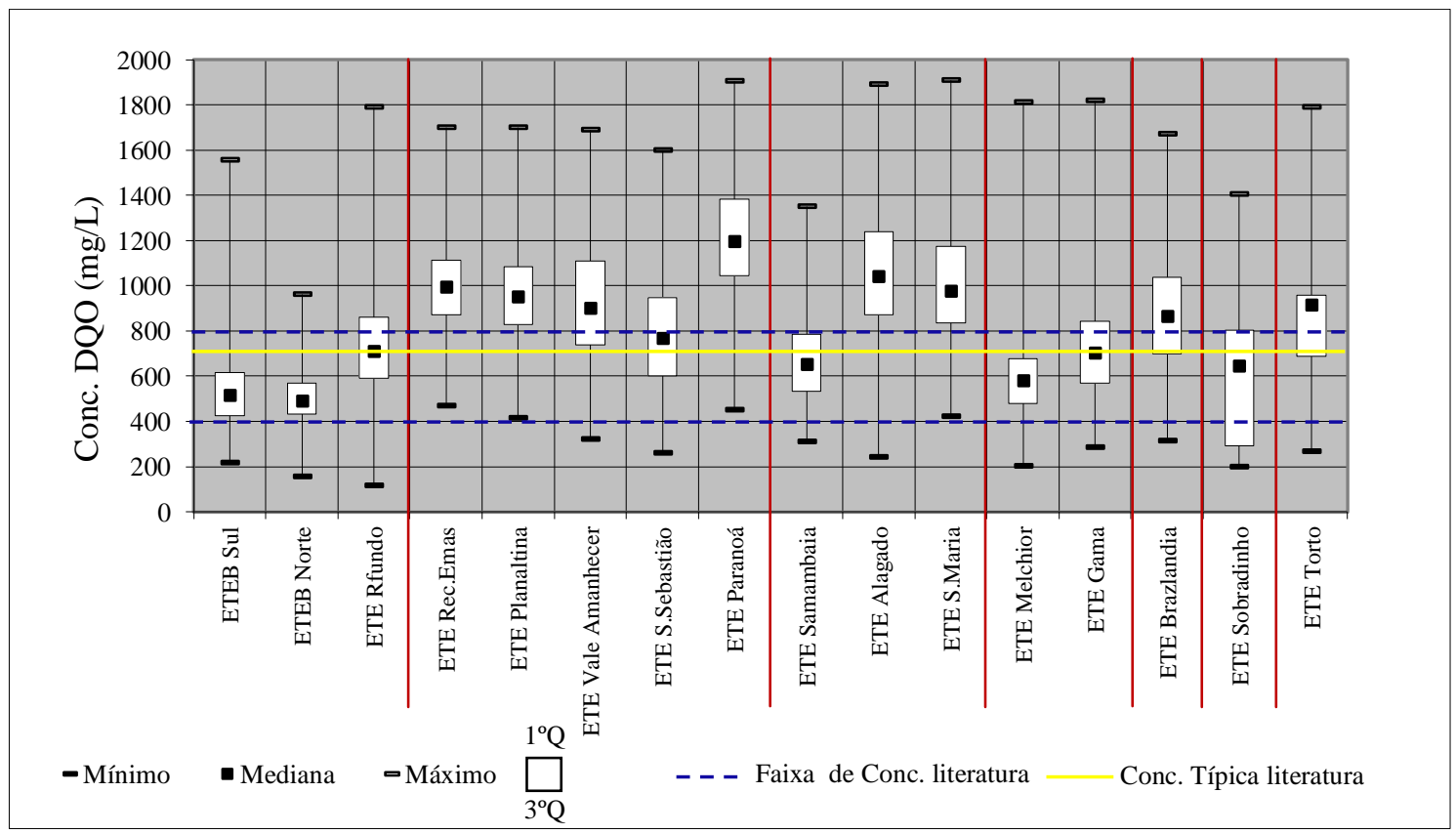

Figura 5.2 - Concentrações dos esgotos afluentes às ETEs do DF, agrupadas por tecnologias de tratamento de esgotos similares - parâmetro DQO (mg/L) - entre anos 2004 $-2013$ 


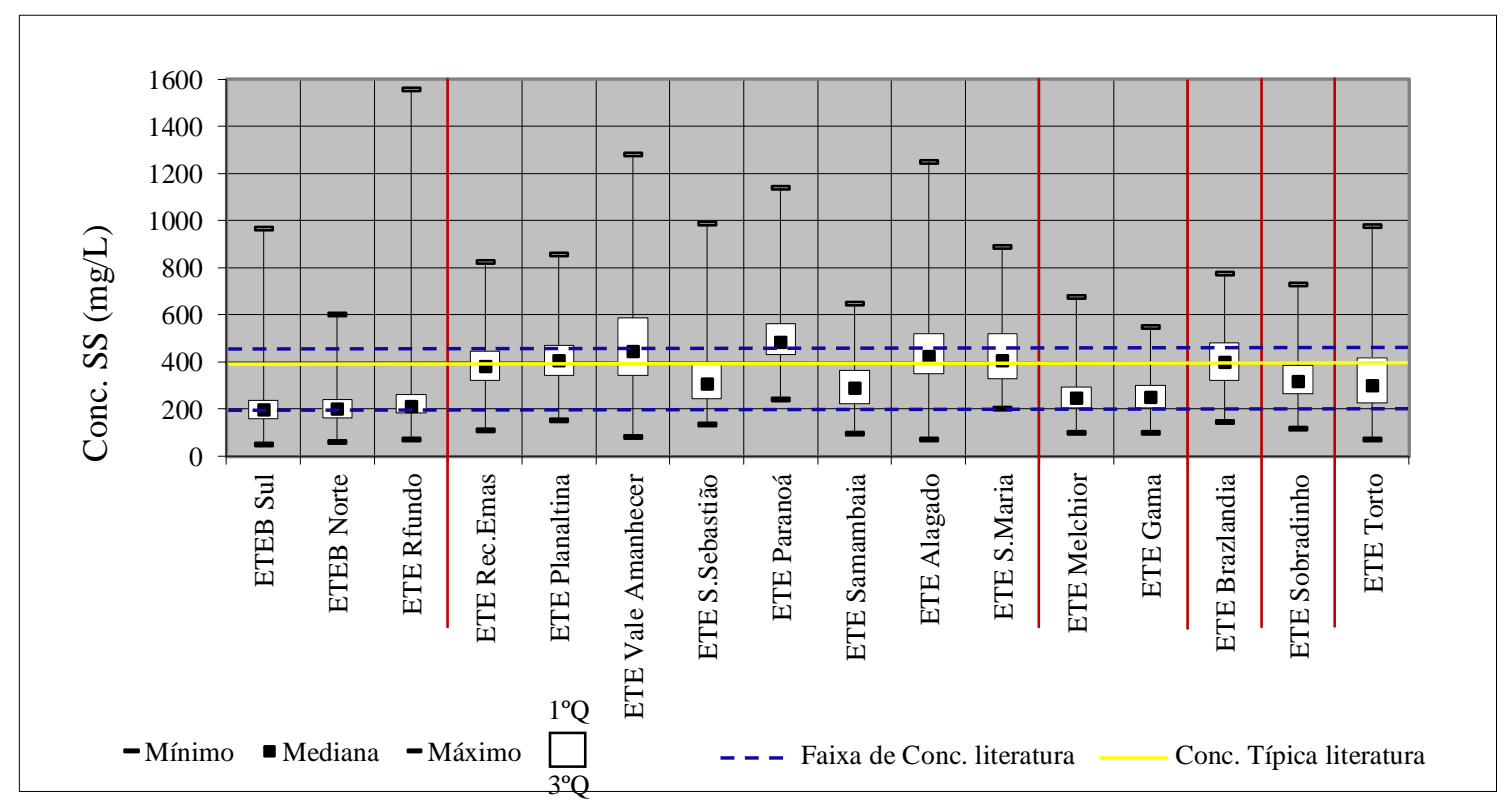

Figura 5.3 - Concentrações dos esgotos afluentes às ETEs do DF, agrupadas por tecnologias de tratamento de esgotos similares - parâmetro SS (mg/L) - entre anos 2004 2013

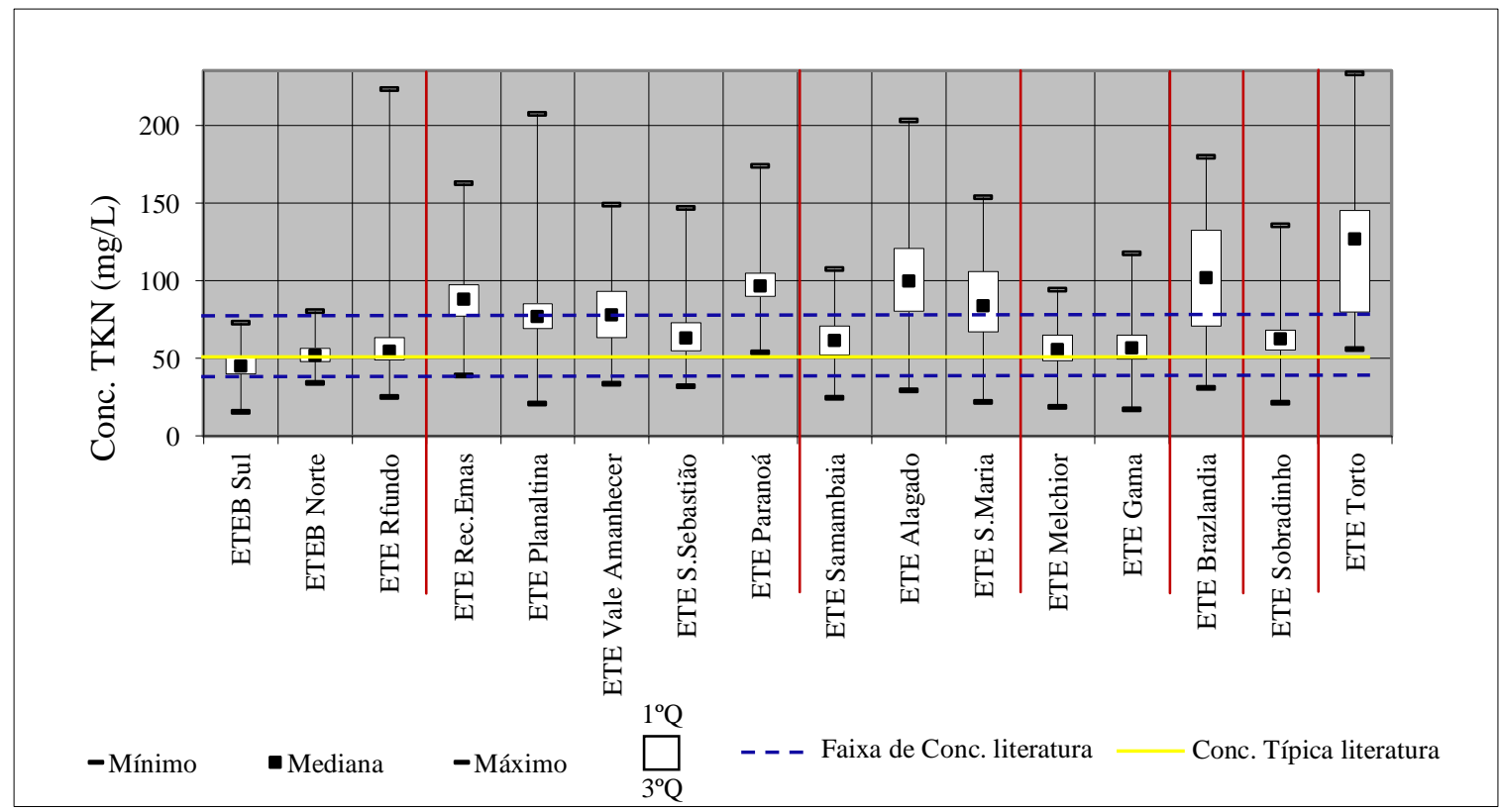

Figura 5.4 - Concentrações dos esgotos afluentes às ETEs do DF, agrupadas por tecnologias de tratamento de esgotos similares - parâmetro TKN (mg/L) - entre anos 2004 $-2013$ 


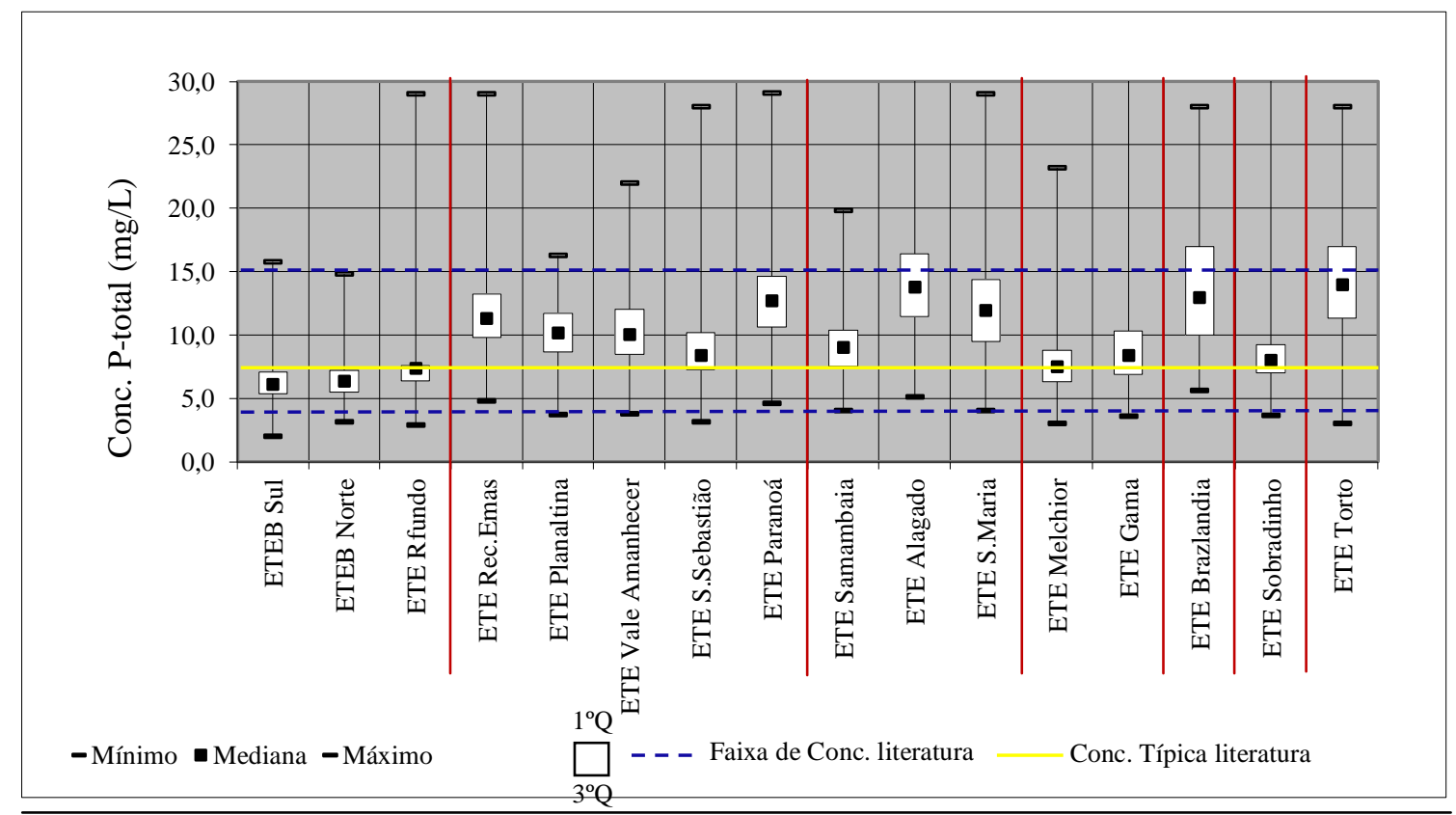

Figura 5.5 - Concentrações dos esgotos afluentes às ETEs do DF, agrupadas por tecnologias de tratamento de esgotos similares - parâmetro P-total (mg/L) - entre anos 2004- 2013

Nota-se pelas informações levantadas e apresentadas nas Tabela 5.3 e 5.4 e visualizadas nas Figuras 5.1 a 5.5 que, para as ETEs com processos de tratamento de esgotos predominantemente aeróbios - ETE Brasília Sul, ETE Brasília Norte, ETE Riacho Fundo, ETE Melchior e ETE Gama - os parâmetros $\mathrm{DBO}_{5}$, DQO, TKN e P-total estiveram dentro da faixa reportada pela literatura. Para algumas estações, ETEs Recanto das Emas, Planaltina, São Sebastião, Paranoá, Vale do Amanhecer, cujas tecnologias de tratamento de esgotos empregadas são uma combinação de reatores anaeróbios e lagoas, as concentrações dos constituintes estão acima das concentrações típicas relatadas.

O parâmetro SS foi o que mais se assemelhou aos valores usuais apresentados na bibliografia consultada, esse parâmetro juntamente com a $\mathrm{DBO}_{5}$, constituem os parâmetros de principal interesse para a estimativa de volumes de esgotos gerados nas ETEs.

Nos gráficos "box-plot", apresentados nas Figuras 5.1 a 5.4, foram considerados todos os dados disponibilizados pelas ETEs, buscando uma visualização da variabilidade do número de dados dos constituintes disponibilizados pelas 16 estações de tratamento. São apresentados nas figuras mencionadas os valores mínimos e máximos, o $1^{\circ}$ e $3^{\circ}$ quartis e a mediana referente aos parâmetros analisados, as faixas usuais e os valores típicos de concentração dos esgotos afluentes às ETEs. 
Uma grande variação no número de dados foi observada entre as diversas ETEs, principalmente para os nutrientes P-total e TKN.

Sobre as causas prováveis para as variações observadas, algumas suposições podem ser levantadas, entretanto, para sua confirmação, seria necessária uma investigação mais aprofundada, o que não é objeto do presente estudo. Essas suposições são as seguintes:

contribuição de efluentes industriais não identificadas;

número de dados distintos por ETEs, maior para aquelas estações com processos mais complexos, caso das ETEs Brasília Sul, Brasília Norte, Gama e Melchior;

metodologia de amostragem diferenciada entre as estações - amostras compostas ao longo de 24 horas e amostragem simples - como ocorre na ETE Torto, que podem sofrer a influencia de cargas pontuais; e

uso e ocupação da bacia, como no caso da bacia do Paranoá, que apresenta diferenças significativas das condições socioeconômicas para as diferentes regiões, com diferentes consumos per capita de água e de coeficientes de retorno, entre outros.

\subsubsection{Geração de lodo de esgotos nas ETEs do Distrito Federal}

O processo de tratamento de esgotos, ao longo de suas etapas, dá origem a diferentes tipos de lodo de esgotos, os quais, por sua vez, passam por fases distintas de tratamento, segundo suas características, concepção do processo de tratamento e destinação final a ser dada ao lodo.

As diferenças mais significativas quanto à variabilidade dos tipos de lodo gerados estão ligadas, obviamente, àquelas ETEs de processos mais complexos. Devido a essa variabilidade, observa-se também uma composição diferenciada dos tratamentos de lodo, denominado tratamento da fase sólida, que também apresenta variações de acordo com o tipo de lodo, instalações das ETEs, localidade, entre outros.

De forma simplificada, as informações quanto aos processos de tratamento de lodos adotados nas ETEs do DF, bem como a distinção entre os diferentes tipos de lodos e os tratamentos aos quais estão submetidos, são apresentadas na Tabela 5.5 e 5.6. 
Tabela 5.5 - Tipos de lodos gerados nas ETEs do Distrito Federal

\begin{tabular}{|c|c|c|c|c|c|c|c|}
\hline $\begin{array}{l}\text { Estações de Tratamento de } \\
\text { Esgotos do DF }\end{array}$ & ○ & 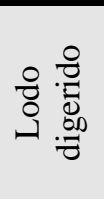 & 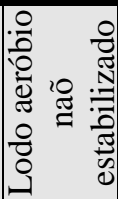 & 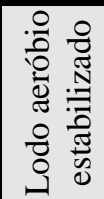 & 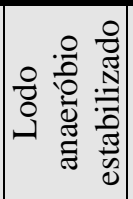 & 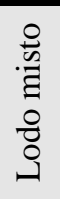 & 兑 \\
\hline ETE Sobradinho & $\mathrm{X}$ & $\mathrm{X}$ & $\mathrm{X}$ & & & & $\mathrm{X}$ \\
\hline ETE Brazlândia & & & & & $\mathrm{X}$ & & \\
\hline ETE Brasília Sul & $\mathrm{X}$ & $\mathrm{X}$ & $\mathrm{X}$ & & & & $\mathrm{X}$ \\
\hline ETE Brasília Norte & $\mathrm{X}$ & $\mathrm{X}$ & $\mathrm{X}$ & & & $\mathrm{X}$ & $\mathrm{X}$ \\
\hline ETE Torto & & & & & $\mathrm{X}$ & & \\
\hline ETE Samambaia & & & & & $\mathrm{X}$ & & $\mathrm{X}$ \\
\hline ETE Paranoá & & & & & $\mathrm{X}$ & & \\
\hline ETE Riacho Fundo & & $\mathrm{X}$ & $\mathrm{X}$ & & & & \\
\hline ETE Alagado & & & & & $\mathrm{X}$ & & $\mathrm{X}$ \\
\hline ETE Planaltina & & & & & $\mathrm{X}$ & & \\
\hline ETE Recanto das Emas & & & $\mathrm{X}$ & & $\mathrm{X}$ & & \\
\hline ETE São Sebastião & & & & & $\mathrm{X}$ & & \\
\hline ETE Vale do Amanhecer & & & & & $\mathrm{X}$ & & \\
\hline ETE Santa Maria & & & & & $\mathrm{X}$ & & \\
\hline ETE Gama & & & & $\mathrm{X}$ & & & $\mathrm{X}$ \\
\hline ETE Melchior & & & & $\mathrm{X}$ & & & $\mathrm{X}$ \\
\hline
\end{tabular}

Nota: Na Tabela 3.2 traz-se uma definição de cada tipo de lodo

Tabela 5.6 - Tipos de tratamento de lodo empregados nas ETEs do Distrito Federal

\begin{tabular}{|c|c|c|c|c|c|c|c|c|}
\hline \multirow[b]{3}{*}{$\begin{array}{l}\text { Estações de Tratamento de } \\
\text { Esgotos do DF }\end{array}$} & \multicolumn{8}{|c|}{ Tratamento empregado } \\
\hline & \multicolumn{2}{|c|}{ Adensamento } & \multicolumn{2}{|c|}{ Estabilização } & \multirow{2}{*}{ 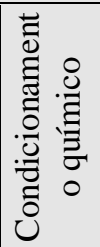 } & \multicolumn{3}{|c|}{ Desaguamento } \\
\hline & 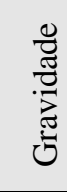 & 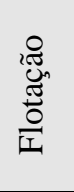 & 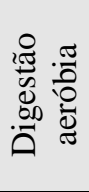 & 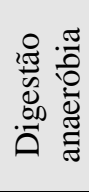 & & $\begin{array}{l}\mathscr{D} \\
\tilde{D} \\
D \\
D\end{array}$ & U & 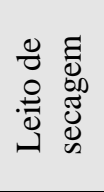 \\
\hline ETE Sobradinho & & & & $\bar{X}$ & $\mathrm{X}$ & & $\bar{X}$ & $\mathrm{X}$ \\
\hline \multicolumn{9}{|l|}{ ETE Brazlândia } \\
\hline ETE Brasília Sul & $\mathrm{X}$ & $\mathrm{X}$ & $X$ & $\mathrm{X}$ & $\mathrm{X}$ & & $\mathrm{X}$ & $\mathrm{X}$ \\
\hline ETE Brasília Norte & $\mathrm{X}$ & $\mathrm{X}$ & & $\mathrm{X}$ & $\mathrm{X}$ & $\mathrm{X}$ & & $\mathrm{X}$ \\
\hline ETE Torto & & & & & & & & $\mathrm{X}$ \\
\hline \multicolumn{9}{|l|}{ ETE Samambaia } \\
\hline ETE Paranoá & & & & & & & & $\mathrm{X}$ \\
\hline ETE Riacho Fundo & & & $\mathrm{X}$ & & $\mathrm{X}$ & & $\mathrm{X}$ & \\
\hline ETE Alagado & & & & & $\mathrm{X}$ & & $\mathrm{X}$ & \\
\hline \multicolumn{9}{|l|}{ ETE Planaltina } \\
\hline ETE Recanto das Emas & & & & & $\mathrm{X}$ & & $\mathrm{X}$ & \\
\hline ETE São Sebastião & & & & & & & & $\mathrm{X}$ \\
\hline \multicolumn{9}{|l|}{ ETE Vale do Amanhecer } \\
\hline \multicolumn{9}{|l|}{ ETE Santa Maria } \\
\hline ETE Gama & & $\mathrm{X}$ & & & $\mathrm{X}$ & & $\mathrm{X}$ & \\
\hline ETE Melchior & & $X$ & & & $\mathrm{X}$ & & $\mathrm{X}$ & \\
\hline
\end{tabular}


Os lodos gerados nas ETEs do Distrito Federal são submetidos aos seguintes tratamentos:

\section{I - Adensamento}

O objetivo principal do adensamento é reduzir o volume de lodo e aumentar a eficácia do manuseio do lodo nas etapas subsequentes, tais como: a estabilização, desaguamento ou transporte (Jordão e Pessoa, 2005). Normalmente, os processos de tratamento de esgotos dão origem a um lodo com característica floculenta, que dificulta o adensamento em altas concentrações.

As características de adensamento do lodo de esgotos podem variar, consideravelmente, não só entre diferentes tipos de lodo, mas também, entre os mesmos tipos de lodo de diferentes localidades. Essas variações podem ser causadas por diversas razões, tais como, variações das propriedades físicas das partículas sólidas, contribuição industrial, tipos e condições de operação e práticas anteriores ao adensamento (WPCF, 1980).

a) Adensamento por gravidade: o lodo originário dos decantadores primários, devido às suas características, é submetido ao adensamento por gravidade, para eliminação da água livre, que retorna ao processo de tratamento da fase líquida. Posteriormente o lodo primário adensado é encaminhado para o os digestores anaeróbios. As ETEs Brasília Sul e Brasília Norte operam com teor de sólidos do lodo primário na ordem de 0,5 a 0,7\%, inferior aos valores apresentados na literatura, em que, de acordo com Andreoli et. al. (2001) admitem-se valores entre 2 a $6 \%$.

A operação do decantador primário, com descartes de lodo mais frequentes, apesar de gerar um lodo menos concentrado, garante uma maior vazão de lodo afluente ao adensador, favorecendo a diminuição do tempo de detenção da fase líquida no adensador, o que é recomendado por diversos autores como forma de diminuir a ocorrência de maus odores.

No caso dessas estações, segundo dados de projeto, é esperado que o adensamento atinja uma concentração do lodo afluente em torno de $9 \%$, entretanto, esse valor não é alcançado, pois o lodo apresenta concentrações médias entre 3,5 e 4,5\% menores do que o reportado na literatura, onde são indicados teores de sólidos totais no lodo adensado, tratando apenas lodo primário, variando entre 5 a 10\% (Jordão e Pessoa, 2005). 
O desempenho dessas unidades e os principais interferentes no processo de adensamento serão comentados posteriormente, por ocasião do estudo de caso.

b) Adensamento por flotação: o lodo biológico é submetido ao adensamento por flotação, tratamento mais indicado na literatura considerando as características do lodo biológico floco leve -, assim, as estações que contam com o processo de lodos ativados possuem as unidades de adensamento por flotação. Entre elas estão as estações Brasília Norte, Brasília Sul, Gama e Melchior. O lodo biológico adensado proveniente dos adensadores das ETEs Brasília Norte e Brasília Sul atingem uma razão de adensamento de cerca de 10 vezes, chegando a concentrações entre 3 a 4,5\%. Conforme Metcalf \& Eddy (1991), o teor de sólidos do lodo secundário flotado pode atingir valores entre 3 e $6 \%$, logo, em termos médios, pode-se inferir que as concentrações nessas ETEs estão dentro dos valores usuais da literatura.

c) Adensamento mecanizado: atualmente, nenhuma estação do Distrito Federal possui unidades de adensamento mecanizado. A ETE Brasília Sul tem prevista para 2015 a instalação de adensamento mecanizado para o lodo bruto e lodo químico, de maneira a reduzir os volumes de lodo gerados na estação e enviados aos digestores de lodo.

As estações que empregam reatores anaeróbios - UASB - seguidos de lagoas, não possuem a etapa de adensamento de lodo, visto que o lodo removido nessas unidades já apresenta concentrações superiores a 3\%.

\section{II - Estabilização:}

O processo de estabilização do lodo consiste na biodegradação de parte da matéria orgânica, reduzindo o potencial de geração de odores e o nível de microrganismos patogênicos. Como o lodo continua com elevadas concentrações de patógenos, a seleção de uma alternativa de disposição final poderá indicar a necessidade de um processo adicional de estabilização, para tornar as características sanitárias do lodo compatíveis com o uso.

Entre as características desejáveis para o lodo, no caso da disposição agrícola, está a presença de nutrientes. As ETEs do Distrito Federal que empregam tecnologias de tratamento de esgotos a nível terciário, ETEs Brasília Sul, Brasília Norte, Gama e Melchior, removem o fósforo pelo mecanismo de retenção celular, de maneira que o lodo dessas estações é rico desse nutriente. 
a) Digestão anaeróbia: as estações Brasília Sul, Brasília Norte e Sobradinho contam com digestores anaeróbios; nesses os lodos provenientes dos decantadores primários, já adensados são submetidos a processos de estabilização, pela ação de microrganismos anaeróbios.

b) Digestão aeróbia: as estações Brasília Sul e Riacho Fundo possuem unidades de digestão aeróbia dos lodos aeróbios provenientes dos reatores biológicos de lodos ativados, que normalmente apresentam uma maior geração de lodo. Segundo Metcalf \& Eddy (1991), o lodo digerido aerobiamente é mais difícil de desaguar que o estabilizado anaerobiamente.

As ETEs Brasília Sul e Brasília Norte apresentam uma diferença substancial no tocante à etapa de estabilização de lodo. As duas estações foram originalmente concebidas para dar um mesmo tratamento à fase sólida. Entretanto, em 2000 foram introduzidas algumas modificações no processo de digestão de lodos da ETEB Norte, que passou a realizar a digestão anaeróbia de todo o lodo produzido na estação (SIESG, 2001).

Dessa forma, na ETEB Norte o lodo primário e o lodo aeróbio, após a etapa de adensamento por gravidade e flotação, respectivamente, são combinados com o lodo químico, dando origem a um lodo misto que segue para o digestor anaeróbio e, posteriormente, para as fases de condicionamento e desaguamento.

A ETEB Sul mantém os digestores aeróbios de lodo e não possui tratamento complementar para digestão do lodo químico. Entretanto, estão em andamento nessa estação diversas obras que promoverão alterações significativas no tratamento da fase sólida, a principal delas é a entrada em operação, prevista para 2015, de outros dois digestores anaeróbios, ampliando a capacidade de digestão anaeróbia de lodo da ETE em mais de 100\%. Isso propiciará a retirada de operação dos digestores aeróbios, bem como o tratamento do lodo químico. Com isso, o fluxo de tratamento da fase sólida seguirá as mesmas etapas empregadas na ETEB Norte.

Essa alteração operacional é bastante significativa considerando-se que a ETE Brasília Sul é responsável por cerca de $50 \%$ de todo o lodo desaguado produzido no Distrito Federal. Diante disso, o conhecimento dos parâmetros operacionais da ETEB Norte adquire grande relevância, à medida que pode nortear as projeções futuras e os resultados esperados no tocante à qualidade e produção de lodo, naturalmente embasados pela literatura, mas que 
podem ser ratificados ou corrigidos em função de uma série histórica de dados. Isso porque ambas as ETEs contam com esgotos afluentes com características muito similares, devido à similaridade da bacia de contribuição, empregam a mesma tecnologia de tratamento de esgotos e, após as obras, terão o mesmo fluxo para o tratamento da fase sólida.

As ETEs Gama e Melchior possuem, no fluxo do processo de tratamento de esgotos, a geração de lodo em duas vias principais, uma é o lodo gerado pelos descartes dos reatores UASB e a outra é o lodo produzido pelos descartes nos reatores biológicos (processo de lodos ativados). Segundo Chernicharo (1997), os lodos gerados nos reatores UASB possuem elevado grau de estabilização, em função do longo tempo de detenção, sendo uma vantagem em relação aos tratamentos aeróbios, pois não necessitam de uma etapa complementar de digestão dos lodos, seguindo diretamente para a fase de desaguamento.

Como ambas as estações, ETE Brasília Sul e ETE Brasília Norte, empregam o tratamento de lodos ativados com aeração prolongada, os lodos oriundos tanto da via anaeróbia, quanto da via aeróbia são considerados lodos estabilizados. Por essa razão, nessas estações, o lodo excedente oriundo dos reatores aeróbios é encaminhado para o adensador por flotação e, na sequência, para as lagoas de lodo, de lá seguem para as unidades de desaguamento de lodo.

No que se refere às condições limites de operação, destaca-se a ETE Sobradinho, que vem operando com sobrecarga devido ao aumento da população contribuinte. Isso levou a uma modificação do seu processo, com a introdução de produtos químicos, no caso o sulfato de alumínio, na etapa de decantação primária, acarretando uma maior geração de lodos, com características de lodo químico. Como a capacidade de digestão não foi ampliada, a estabilização do lodo foi prejudicada, em função da redução do tempo de digestão. Estão em andamento na ETE Sobradinho, desde 2010, obras de melhoria e ampliação.

III - Condicionamento e desaguamento de lodos

As estações que possuem tratamento aeróbio e, em consequência, apresentam maior produção de lodos, contam com etapas de condicionamento e desidratação de lodo. Entre elas estão as ETEs Brasília Sul, Brasília Norte, Riacho Fundo, Sobradinho, Gama e Melchior. 
As estações Recanto das Emas e Alagado, apesar de concebidas com processos essencialmente anaeróbios, também dispõem de unidades de condicionamento e desaguamento de lodos. A ETE Alagado, entretanto, devido a alguns limitantes operacionais, ainda não iniciou o funcionamento da sua unidade de desaguamento.

Todas as ETEs que contam com unidades de desidratação mecânica, são precedidas pela etapa de condicionamento de lodo com polímero catiônico.

Os equipamentos instalados para a desidratação mecânica de lodos no Distrito Federal são, predominantemente, as centrífugas. Os resultados esperados para remoção de umidade para estes equipamentos, da ordem de $25 \%$ de ST, mencionados pelos fabricantes, dificilmente são alcançados, normalmente estão entre 17 e $22 \%$ de ST. Isto pode ser atribuído a uma deficiência na etapa de estabilização do lodo.

A estação Brasília Norte tem instaladas prensas desaguadoras, também chamadas "belt press", que apresentam resultados de teor de umidade na faixa de $85-88 \%$. A ETEB Sul tem instaladas quatro centrífugas, cujos resultados de teor de umidade vem apresentando significativa melhora, atualmente os valores estão entre 82 e $85 \%$, em algumas situações chegam a atingir 80\%. Está prevista para 2015 a ampliação da capacidade de desaguamento da ETEB Norte, com a instalação de uma centrífuga.

Nas estações que preveem a remoção biológica de fósforo, o lodo gerado é rico desse nutriente, sendo uma das características mais atrativas para o uso agrícola desse material. $\mathrm{Na}$ etapa de desaguamento, parte desse fósforo é eliminada juntamente com a água. Como todo o sobrenadante retorna ao processo de tratamento de esgotos, para diminuir a carga de fósforo recirculado, as ETEs Brasília Norte e Brasília Sul, possuem uma etapa adicional em que a água residual, proveniente do desaguamento, passa por tanques onde recebem solução de cal, elevando o $\mathrm{pH}$ a aproximadamente 9 , favorecendo a precipitação química de fósforo. Esse efluente líquido é, posteriormente, encaminhado a um decantador. O lodo separado retorna às unidades de desaguamento e o sobrenadante retorna ao início da estação. Dessa forma, apenas uma parcela do fósforo retorna ao inicio da estação, outra parte (precipitado no decantador) fica retido no lodo.

As demais estações contam com sistemas naturais de desidratação de lodo, ou seja, leitos de secagem e ou lagoas de lodo, como as ETEs Paranoá, Vale do Amanhecer, Planaltina, São Sebastião, Santa Maria, ou, como ocorre com as ETEs Brazlândia e Torto, que não 
possuem unidades de desidratação. Nesse caso o lodo fica retido nas próprias unidades de tratamento de esgotos e, podem ser removidos caso haja a programação de limpeza, estabelecida de acordo com as condições operacionais da estação.

Dessa forma, nem todas as estações são dotadas de unidades de desidratação de lodo.

\subsubsection{Produção de lodos de esgotos nas ETEs do DF}

Para a determinação da quantidade de lodos gerados nas ETEs do Distrito Federal, foram levantados os dados operacionais relativos aos volumes de lodo computados em cada estação de tratamento de esgotos. Os dados disponibilizados pela CAESB, por meio dos relatórios operacionais, não trazem informações sobre o volume de lodo gerado nas fases intermediárias.

Isso ocorre porque, conforme mencionado anteriormente, diversas rotinas de descartes de lodo, tais como o descarte nos reatores anaeróbios, são condicionados pela disponibilidade das unidades de processamento e armazenamento de lodo. No caso dos descartes de lodo excedente dos reatores biológicos de lodos ativados, apenas as ETEs Brasília Sul e Brasília Norte realizam um controle do volume de lodo removido, por meio de medidor de vazão instalado na rede de bombeamento para os adensadores por flotação.

$\mathrm{Na}$ maioria das estações não há medidores de vazão nas linhas de descarte de lodo. A determinação do volume de lodo, quando é realizada, é feita por meio da quantificação volumétrica nas unidades de armazenamento intermediário, lagoas de lodo ou leitos de secagem, ou ainda pela quantidade removida em caminhões do tipo limpa-fossa.

I - Produção de lodo afluente às unidades de desaguamento

Apenas as ETEs Brasília Sul, Brasília Norte, Melchior e Riacho Fundo disponibilizaram dados do volume diário de lodo a ser desaguado, entre os anos de 2013 e 2014. No caso da ETE Gama, foram apresentados apenas os volumes médios mensais. A ETE Paranoá apresentou dados de lodo descartado do UASB em 2014. Os dados foram tratados pela técnica de estatística descritivas e são apresentados na Figuras 5.6 e 5.7 e Tabela 5.7. 
Tabela 5.7 - Parâmetros e Indicadores de geração de lodo (afluente ao desaguamento), dados médios entre os anos de 2013 e 2014

\begin{tabular}{|c|c|c|c|c|c|c|}
\hline Parâmetros & $\begin{array}{l}\text { ETEB } \\
\text { SUL }\end{array}$ & $\begin{array}{l}\text { ETEB } \\
\text { NORTE }\end{array}$ & $\begin{array}{c}\text { ETE } \\
\text { MELCHIOR }\end{array}$ & ETE GAMA & $\begin{array}{c}\text { ETE } \\
\text { RIACHO } \\
\text { FUNDO } \\
\end{array}$ & $\begin{array}{c}\text { ETE } \\
\text { PARANOÁ }^{1}\end{array}$ \\
\hline $\begin{array}{l}\text { Volume de esgotos afluente } \\
\left(\mathrm{m}^{3 / \mathrm{d})}\right.\end{array}$ & 91.569 & 41.181 & 74.305 & 17.873 & 4.147 & 7.558 \\
\hline $\begin{array}{l}\text { Carga Orgânica afluente } \\
(\mathrm{KgDBO} / \mathrm{d})\end{array}$ & 32.240 & 13.042 & 25.149 & 6.153 & 2.155 & 5.141 \\
\hline $\begin{array}{l}\text { Carga Orgânica afluente } \\
\text { (KgDBO/ m³esgoto tratado.d) }\end{array}$ & 0,35 & 0,32 & 0,34 & 0,34 & 0,52 & 0,68 \\
\hline $\begin{array}{l}\text { Carga Orgânica efluente } \\
(\mathrm{kgDBO} / \mathrm{d})\end{array}$ & 1.618 & 618 & 2.308 & 141 & 46 & 1.385 \\
\hline $\begin{array}{l}\text { Volume lodo afluente ao } \\
\text { desaguamento }\left(\mathrm{m}^{3} / \mathrm{d}\right)\end{array}$ & 2.159 & 467 & 476 & 150 & 102 & 15 \\
\hline $\begin{array}{l}\text { Volume lodo desaguado (torta) } \\
\left(\mathrm{m}^{3} / \mathrm{d}\right)\end{array}$ & 162 & 73 & 50 & 23 & 6 & - \\
\hline Eficiência remoção DBO (\%) & 92,5 & 96 & 90 & 98 & 97,5 & 73 \\
\hline DBO removida $(\mathrm{Kg} / \mathrm{d})$ & 30.622 & 12.424 & 22.841 & 6.012 & 2.110 & 3.756 \\
\hline $\begin{array}{l}\text { DBO removida }\left(\mathrm{Kg} / \mathrm{m}^{3} \text { esgoto }\right. \\
\text { tratado.d) }\end{array}$ & 0,33 & 0,30 & 0,31 & 0,34 & 0,51 & 0,50 \\
\hline $\begin{array}{l}\mathrm{I}=\mathrm{m}^{3} \_ \text {lodo } / \mathrm{Kg} . \mathrm{DBO} \\
\text { removida.d }\end{array}$ & 0,07 & 0,04 & 0,02 & 0,02 & 0,05 & 0,004 \\
\hline
\end{tabular}

Notas: (1) Os dados informados referem-se a 2014

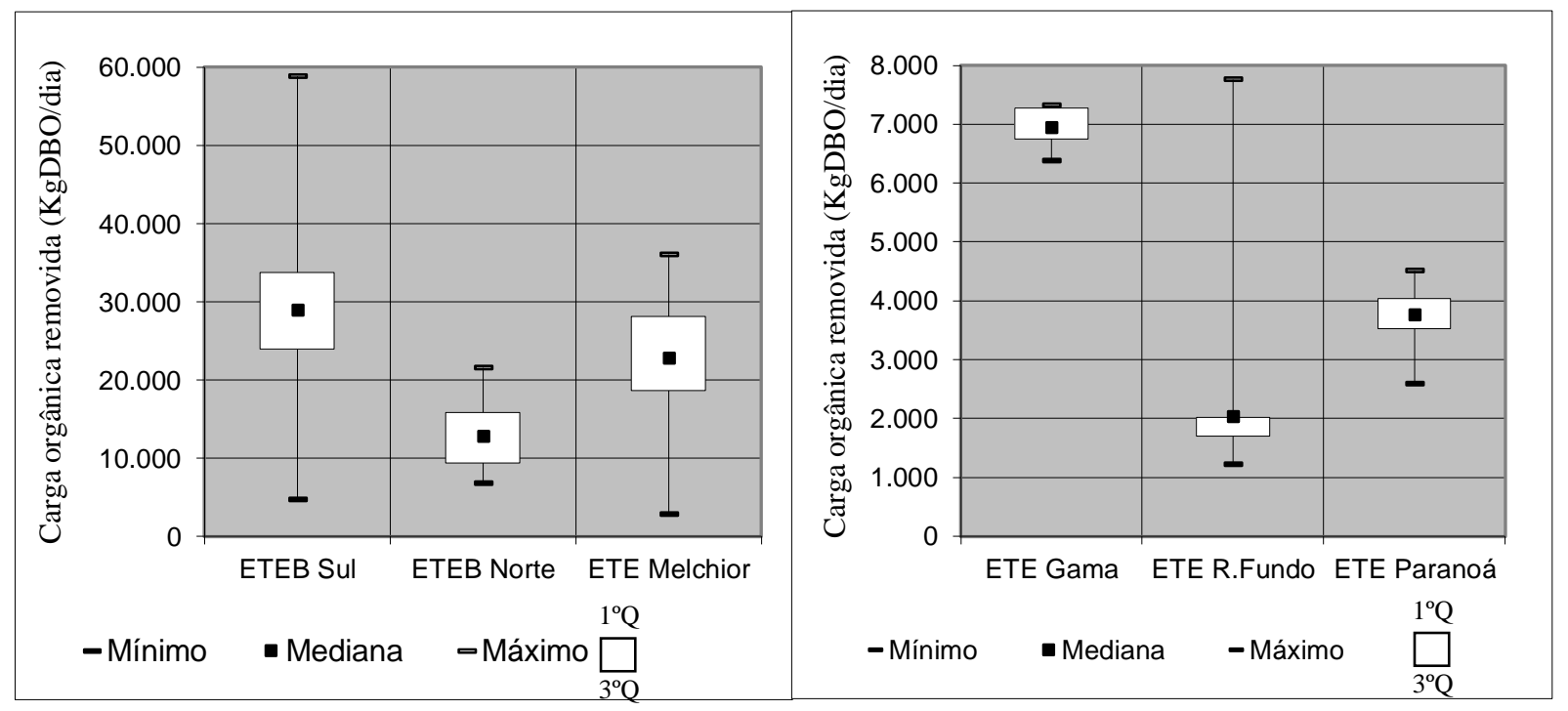

Figura 5.6 - Carga orgânica removida das ETEs Brasília Sul, Brasília Norte, Melchior, Gama, Riacho Fundo e Paranoá (KgDBO/dia) - 2013 e 2014 


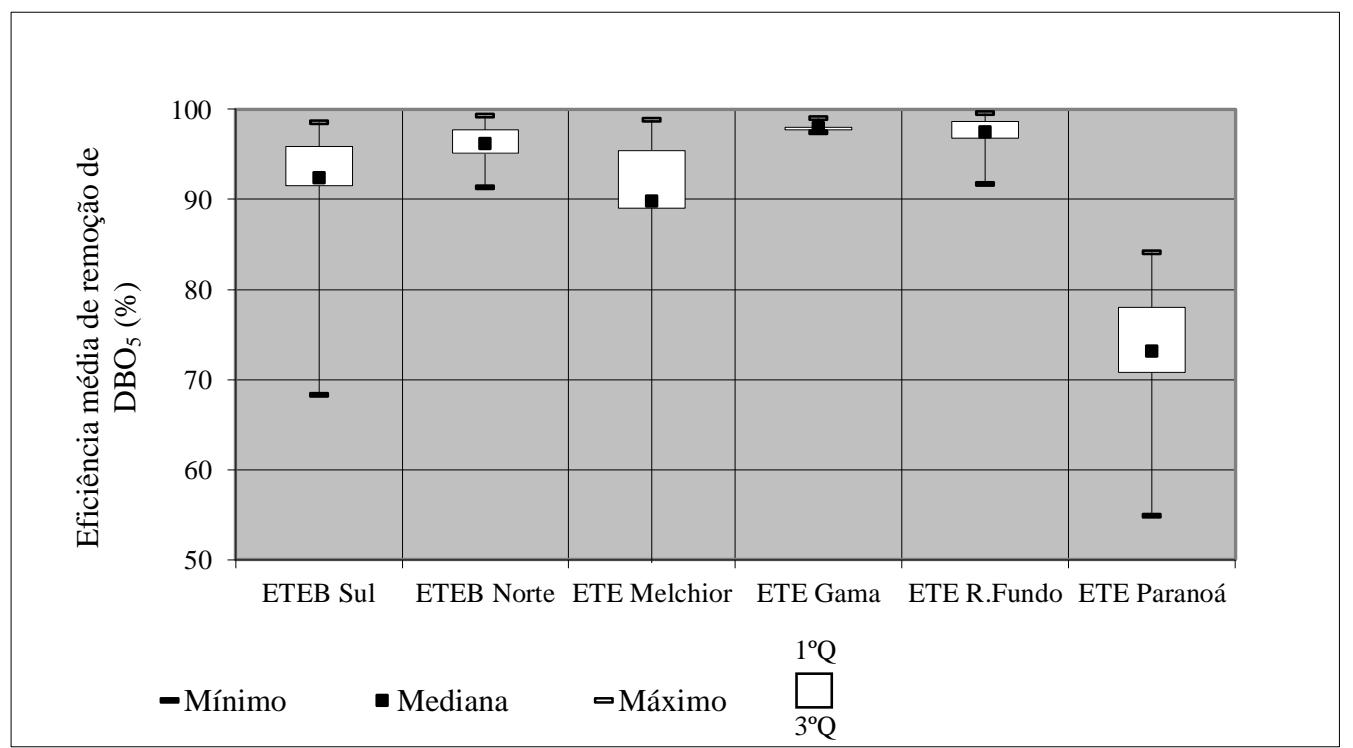

Figura 5.7 - Eficiência média de remoção de $\mathrm{DBO}_{5}$ registradas nas ETEs Brasília Sul, Brasília Norte, Melchior, Gama, Riacho Fundo e Paranoá (\%) - $2013^{1}$ e 2014 Nota: (1) Os dados da ETE Paranoá se referem a 2014.

Pelos dados apresentados, comprova-se, por meio do indicador de produção de lodo - I, uma maior produção relativa de lodo para aquelas ETEs em que as tecnologias empregadas são predominantemente aeróbias, caso das ETEs Brasília Sul, Brasília Norte e Riacho Fundo. No caso das ETEs Melchior e Gama, em que há uma combinação de tratamento anaeróbio (UASB) e tratamento aeróbio (lodos ativados com aeração prolongada) a produção relativa de lodo é cerca de 50\% menor e a ETE Paranoá que emprega apenas tratamento anaeróbio (UASB), mesmo com as maiores concentrações relativas de carga orgânica afluente, produz aproximadamente $10 \%$ do volume de lodo que as ETEs com tratamento aeróbio.

II - Produção de lodo desaguado

A produção de lodo desaguado, base úmida, dos últimos dez anos foi levantada, e conforme observado na Tabela 5.8 e Figura 5.8, ao longo desse período a geração de lodo tem sido incrementada, reflexo dos avanços no atendimento da população com o tratamento de esgotos. Entretanto, verifica-se que nos dois últimos anos ocorreu um recuo na produção de lodo desaguado.

Segundo informações dos operadores do sistema, algumas alterações operacionais nos processos internos podem ter favorecido essa redução, entretanto, a justificativa mais 
provável para essa diminuição diz respeito às limitações das unidades de desaguamento de lodo. Dessa forma, os valores não expressam uma redução na geração do lodo, mas uma queda na produtividade das unidades de desidratação, e o lodo, nesses casos, fica acumulado nas unidades intermediárias, tais como lagoas de lodo e leitos de secagem, além de estocados em tanques que deveriam ser unidades reserva do sistema.

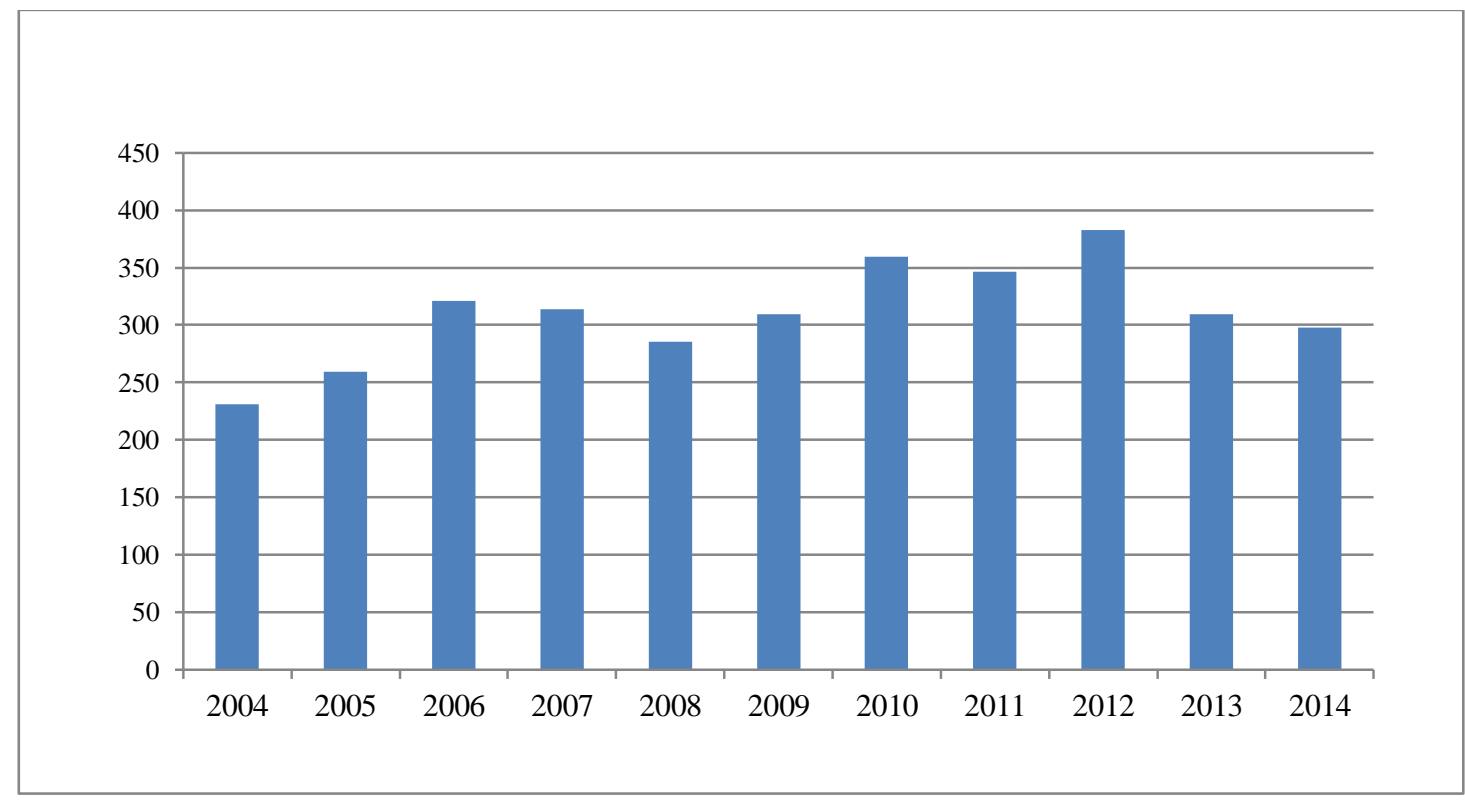

Figura 5.8 - Evolução da Produção de Lodo no Distrito Federal (ton/d) entre os anos de 2004 e 2014

$\mathrm{Na}$ Tabela 5.8, a seguir, são apresentados os dados de produção de lodo desaguado no Distrito Federal, ao longo dos últimos onze anos. 
Tabela 5.8 - Produção de lodo nas ETEs do Distrito Federal (ton/ano) - Período 2004 a 2014

\begin{tabular}{|c|c|c|c|c|c|c|c|c|c|c|c|}
\hline ETEs & 2004 & 2005 & 2006 & 2007 & 2008 & 2009 & 2010 & 2011 & 2012 & 2013 & 2014 \\
\hline ETE Sul & 49.647 & 53.844 & 54.424 & 59.057 & 53.093 & 62.732 & 59.593 & 56.916 & 61.306 & $69.571^{1}$ & $60.922^{1}$ \\
\hline ETE Norte & 22.763 & 23.412 & 28.875 & 22.032 & 20.369 & 21.042 & 22.316 & 24.682 & 24.399 & 22.774 & 23.023 \\
\hline ETE Melchior & & 0 & 15.673 & 20.894 & 14.993 & 13.819 & 18.510 & 9.745 & 14.914 & 9.086 & 13.534 \\
\hline ETE Gama & 3.234 & 7.259 & 6.390 & 6.709 & 8.275 & 7.836 & 5.907 & 8.499 & 9.397 & 4.307 & 8.537 \\
\hline ETE Recanto das Emas & 3.878 & 5.281 & 9.356 & 4.558 & 4.357 & 952 & 3.616 & 2.307 & 13.191 & 4.378 & 1.740 \\
\hline ETE Sobradinho & 0 & 0 & 0 & 225 & 497 & 4.013 & 17.018 & 17.500 & 9.867 & 2.302 & 1.139 \\
\hline ETE Riacho Fundo & 2.959 & 2.880 & 2.025 & 680 & 1.022 & 1.404 & 520 & 1.561 & 778 & 551 & \\
\hline ETE São Sebastião & 0 & 0 & & & 410 & 1.039 & 3.764 & 3.907 & 5.026 & & \\
\hline ETE Paranoá & 1.750 & 1.870 & 360 & 381 & 1.200 & & & 1.281 & 744 & & \\
\hline ETE Alagado & & & & 138 & & 6.804 & & & & & \\
\hline Produção anual total (ton) & 84.231 & 94.546 & 117.103 & 114.536 & 104.216 & 112.837 & 131.244 & 126.398 & 139.622 & 112.969 & 108.895 \\
\hline Produção diária (ton) & 231 & 259 & 321 & 314 & 286 & 309 & 360 & 346 & 383 & 309 & 298 \\
\hline
\end{tabular}

Fonte: Adaptado de SIESG (2013) e Relatórios operacionais POE/DP/CAESB (2004 a 2014).

Nota: (1) valores corrigidos segundo informações dos operadores do sistema, visto que os dados divulgados não computavam a produção de lodo de uma das centrífugas. 


\subsubsection{Características sanitárias dos lodos gerados nas ETEs do Distrito Federal}

As tecnologias de tratamento biológico de esgotos, normalmente, atuam na remoção de microrganismos patogênicos presentes no esgoto pela sua captura e concentração no lodo originado pelo processo de tratamento.

Dessa forma, as características qualitativas, no tocante aos aspectos sanitários do lodo, estão intimamente relacionadas com a concentração destes microrganismos, que por sua vez, são influenciados por diversos fatores, tais como as condições socioeconômicas da população, o perfil de saúde da comunidade atendida pelo SES, a tecnologia de tratamento de esgotos empregada, e o tipo de tratamento a que o lodo foi submetido.

Aliado a isso, a análise das informações relativas à qualidade sanitária dos lodos gerados no Distrito Federal considerou também a distinção entre os processos de tratamento a que os lodos são submetidos e as variáveis operacionais de cada estação, principalmente porque, segundo levantamento realizado, mesmo para processos similares, as estratégias adotadas no tocante a descartes de lodo, controle do tempo de detenção hidráulica e da biomassa e instalações intermediárias de armazenamento de lodo são individualizadas e não obedecem a um padrão de controle pré-definido.

Os principais microrganismos caracterizados nos lodos gerados no Distrito Federal são as bactérias do grupo coliformes termotolerantes e os helmintos. Vale ressaltar que os dados levantados se referem ao monitoramento da sanidade do lodo desaguado, realizada nos laboratórios de microbiologia da CAESB, portanto abrangem apenas aquelas unidades que, no fluxo de tratamento da denominada fase sólida, contam com unidades de desaguamento de lodo.

Os resultados mostrados na Tabela 5.9 e nas figuras 5.9 e 5.10 retratam as concentrações de bactérias coliformes termotolerantes em NMP/g matéria seca de lodo desaguado. 
Tabela 5.9 - Estatística descritiva referente às concentrações de coliformes termotolerantes nos lodos desaguados das ETEs do DF

\begin{tabular}{|c|c|c|c|}
\hline $\begin{array}{c}\text { Processo de } \\
\text { estabilização }\end{array}$ & ETE & Estatística & $\begin{array}{c}\text { Resultados bacteriológicos } \\
\text { coliformes termotolerantes } \\
\text { NMP/g matéria seca }\end{array}$ \\
\hline \multirow{3}{*}{$\begin{array}{l}\text { Digestão } \\
\text { anaeróbia }\end{array}$} & ETEB Norte & $\begin{array}{l}\mathrm{N}^{\mathrm{o}} \text { de dados } \\
\text { Média } \\
\text { Máx/Mín } \\
\text { Mediana } \\
\text { Desvio padrão }\end{array}$ & $\begin{array}{c}125 \\
9,20 \mathrm{E}+05 \\
1,30 \mathrm{E}+07 / 1,30 \mathrm{E}+03 \\
3,61 \mathrm{E}+05 \\
1,84 \mathrm{E}+06\end{array}$ \\
\hline & $\begin{array}{l}\text { ETE Rec. das } \\
\text { Emas }\end{array}$ & $\begin{array}{l}\mathrm{N}^{\mathrm{o}} \text { de dados } \\
\text { Média } \\
\text { Máx/Mín } \\
\text { Mediana } \\
\text { Desvio padrão }\end{array}$ & $\begin{array}{c}36 \\
2,47 \mathrm{E}+05 \\
6,48 \mathrm{E}+06 / 1,05 \mathrm{E}+02 \\
3,8 \mathrm{E}+03 \\
1,11 \mathrm{E}+06\end{array}$ \\
\hline & $\begin{array}{l}\text { ETE } \\
\text { Sobradinho }\end{array}$ & $\begin{array}{l}\text { No de dados } \\
\text { Média } \\
\text { Máx./Mín } \\
\text { Mediana } \\
\text { Desvio padrão }\end{array}$ & $\begin{array}{c}8 \\
2,65 \mathrm{E}+06 \\
1,47 \mathrm{E}+07 / 3,24 \mathrm{E}+05 \\
8,52 \mathrm{E}+05 \\
4,88 \mathrm{E}+06\end{array}$ \\
\hline $\begin{array}{l}\text { Digestão } \\
\text { aeróbia }\end{array}$ & ETE RFundo & $\begin{array}{l}\text { No de dados } \\
\text { Média } \\
\text { Máx./Mín } \\
\text { Mediana } \\
\text { Desvio padrão }\end{array}$ & $\begin{array}{c}72 \\
1,13 \mathrm{E}+06 \\
2,24 \mathrm{E}+07 / 1,99 \mathrm{E}+03 \\
1,21 \mathrm{E}+05 \\
3,83 \mathrm{E}+06\end{array}$ \\
\hline \multirow{3}{*}{$\begin{array}{l}\text { Digestão } \\
\text { anaeróbia + } \\
\text { Estabilização } \\
\text { aeróbia (Reator } \\
\text { biológico } \\
\text { c/aeração } \\
\text { prolongada) }\end{array}$} & ETEB Sul $^{1}$ & $\begin{array}{l}\text { No de dados } \\
\text { Média } \\
\text { Máx./Mín } \\
\text { Mediana } \\
\text { Desvio padrão }\end{array}$ & $\begin{array}{c}115 \\
9,92 \mathrm{E}+06 \\
5,22 \mathrm{E}+035,41 \mathrm{E}+06 \\
7,10 \mathrm{E}+07 \\
1,31 \mathrm{E}+07\end{array}$ \\
\hline & ETE Gama & $\begin{array}{l}\mathrm{N}^{\circ} \text { de dados } \\
\text { Média } \\
\text { Máx./Mín } \\
\text { Mediana } \\
\text { Desvio padrão }\end{array}$ & $\begin{array}{c}76 \\
1,74 \mathrm{E}+06 \\
1,98 \mathrm{E}+07 / 6,52 \mathrm{E}+03 \\
5,81 \mathrm{E}+05 \\
3,02 \mathrm{E}+06 \\
\end{array}$ \\
\hline & $\begin{array}{l}\text { ETE } \\
\text { Melchior }\end{array}$ & $\begin{array}{l}\mathrm{N}^{\circ} \text { de dados } \\
\text { Média } \\
\text { Máx./Mín } \\
\text { Mediana } \\
\text { Desvio padrão }\end{array}$ & $\begin{array}{c}89 \\
1,40 \mathrm{E}+06 \\
1,97 \mathrm{E}+07 / 1,73 \mathrm{E}+04 \\
5,37 \mathrm{E}+05 \\
2,85 \mathrm{E}+06 \\
\end{array}$ \\
\hline
\end{tabular}

Nota: (1) A estabilização do lodo na ETEB Sul compreende a digestão anaeróbia do lodo primário e a digestão aeróbia do lodo aeróbio (reatores biológicos), o lodo químico não passa por processo de digestão. 


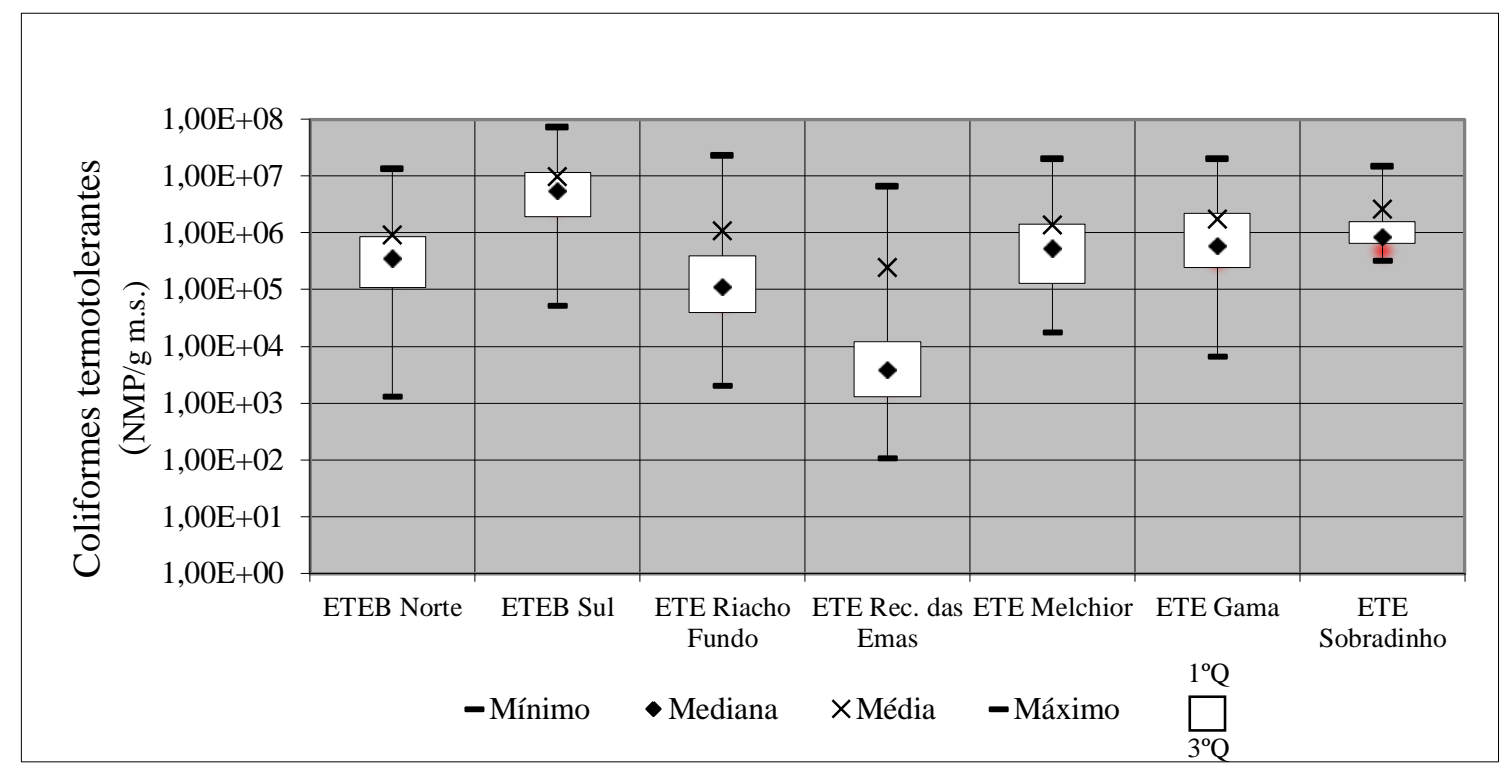

Figura 5.9 - Resultados de Coliformes termotolerantes(NMP/g m.s.) nos lodos desaguados no Distrito Federal (2007 - 2014)

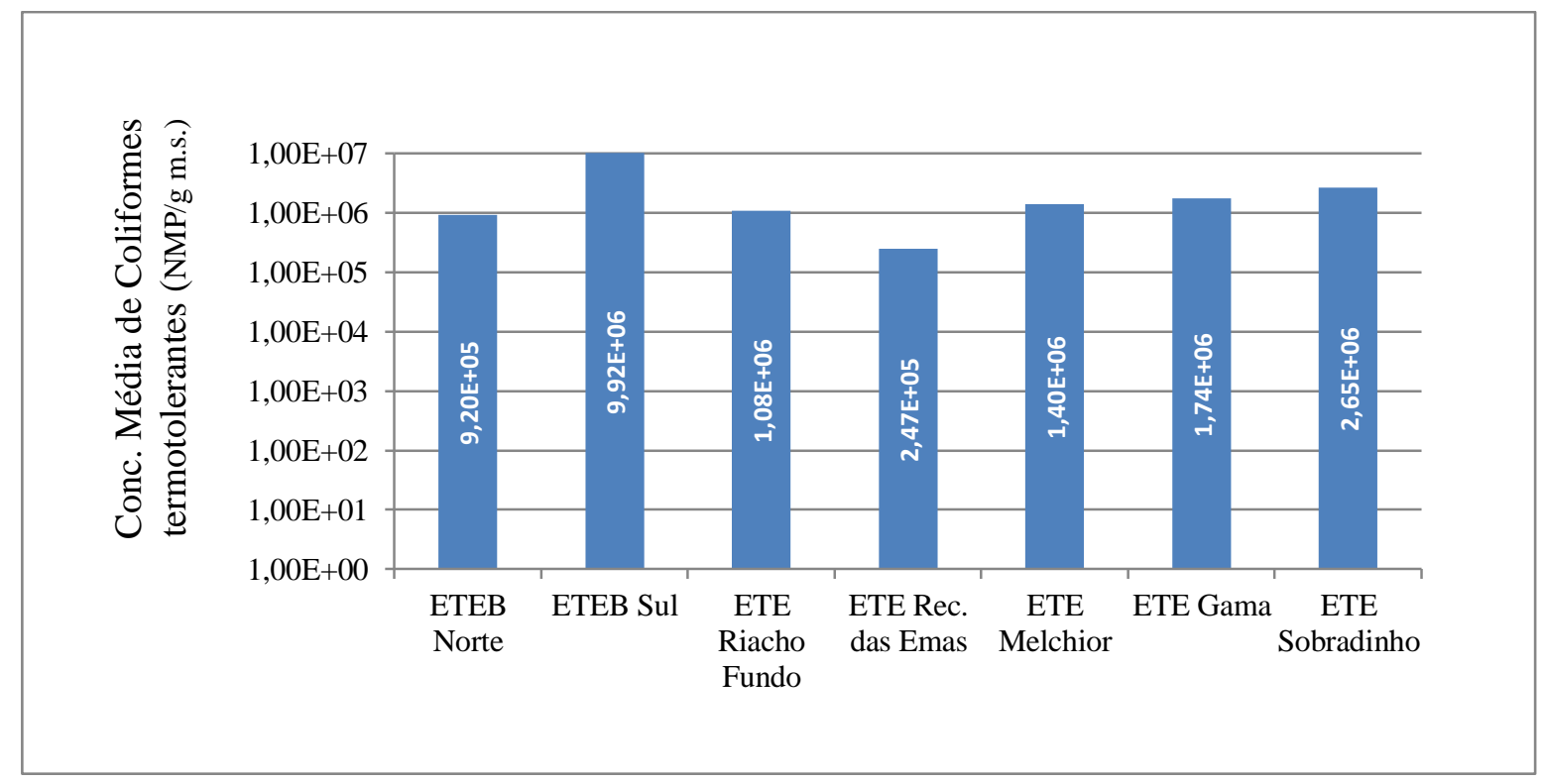

Figura 5.10 - Resultados de coliformes termotolerantes nos lodos desaguados gerados no Distrito Federal (2007 - 2014) - média anual.

Os resultados de parasitologia, para os parâmetros ovos de helmintos e ovos viáveis de helmintos são apresentados na Tabela 5.10 e Figura 5.11. 
Tabela 5.10 - Estatística descritiva referente às concentrações de ovos de helmintos e ovos viáveis de helmintos nos lodos desaguados das ETEs do DF

\begin{tabular}{|c|c|c|c|c|}
\hline $\begin{array}{c}\text { Processo de } \\
\text { estabilização }\end{array}$ & ETE & Estatística & $\begin{array}{c}\mathrm{N}^{\mathrm{o}} \text { de ovos de } \\
\text { helmintos/g matéria } \\
\text { seca }\end{array}$ & $\begin{array}{c}\mathrm{N}^{\mathrm{o}} \text { de ovos viáveis } \\
\text { de helmintos/g } \\
\text { matéria seca }\end{array}$ \\
\hline \multirow{15}{*}{$\begin{array}{l}\text { Digestão } \\
\text { anaeróbia }\end{array}$} & \multirow{5}{*}{ ETEB Norte } & $\mathrm{N}^{\circ}$ de dados & 112 & 112 \\
\hline & & Média & 1,28 & 1,19 \\
\hline & & Máx/Mín & $4,39 / 0,00$ & $4,39 / 0,00$ \\
\hline & & Mediana & 1,19 & 1,16 \\
\hline & & Desvio padrão & 1,00 & 0,97 \\
\hline & \multirow{5}{*}{$\begin{array}{l}\text { ETE Rec. das } \\
\text { Emas }\end{array}$} & $\mathrm{N}^{\mathrm{o}}$ de dados & 24 & 24 \\
\hline & & Média & 4,51 & 3,65 \\
\hline & & Máx/Mín & $15,91 / 0,41$ & $11,00 / 0,00$ \\
\hline & & Mediana & 3,20 & 2,59 \\
\hline & & Desvio padrão & 4,05 & 3,28 \\
\hline & \multirow{5}{*}{$\begin{array}{l}\text { ETE } \\
\text { Sobradinho }\end{array}$} & $\mathrm{N}^{\mathrm{o}}$ de dados & 6 & 6 \\
\hline & & Média & 6,3 & 5,23 \\
\hline & & Máx./Mín & $11,84 / 2,13$ & $8,98 / 0,00$ \\
\hline & & Mediana & 5,66 & 5,66 \\
\hline & & Desvio padrão & 3,97 & 3,78 \\
\hline \multirow{5}{*}{$\begin{array}{l}\text { Digestão } \\
\text { aeróbia }\end{array}$} & \multirow{5}{*}{ ETE RFundo } & $\mathrm{N}^{\circ}$ de dados & 52 & 52 \\
\hline & & Média & 7,50 & 6,36 \\
\hline & & Máx./Mín & $36,19 / 0,00$ & $28,57 / 0,00$ \\
\hline & & Mediana & 5,40 & 4,54 \\
\hline & & Desvio padrão & 7,33 & 5,99 \\
\hline \multirow{15}{*}{$\begin{array}{l}\text { Digestão } \\
\text { anaeróbia + } \\
\text { Estabilização } \\
\text { aeróbia } \\
\text { (Reator } \\
\text { biológico } \\
\text { c/aeração } \\
\text { prolongada) }\end{array}$} & \multirow{5}{*}{ ETEB Sul } & $\mathrm{N}^{\mathrm{o}}$ de dados & 89 & 89 \\
\hline & & Média & 1,64 & 1,51 \\
\hline & & Máx./Mín & $7,00 / 0,00$ & $7,00 / 0,00$ \\
\hline & & Mediana & 1,19 & 1,13 \\
\hline & & Desvio padrão & 1,50 & 1,41 \\
\hline & \multirow{5}{*}{ ETE Gama } & $\mathrm{N}^{\mathrm{o}}$ de dados & 73 & 73 \\
\hline & & Média & 9,29 & 8,25 \\
\hline & & Máx./Mín & $31,87 / 0,00$ & $30,23 / 0,00$ \\
\hline & & Mediana & 6,90 & 6,11 \\
\hline & & Desvio padrão & 7,31 & 6,54 \\
\hline & \multirow{5}{*}{$\begin{array}{l}\text { ETE } \\
\text { Melchior }\end{array}$} & $\mathrm{N}^{\mathrm{o}}$ de dados & 103 & 103 \\
\hline & & Média & 5,66 & 5,01 \\
\hline & & Máx./Mín & $27,80 / 0,00$ & $21,90 / 0,00$ \\
\hline & & Mediana & 4,22 & 4,05 \\
\hline & & Desvio padrão & 5,58 & 4,91 \\
\hline
\end{tabular}




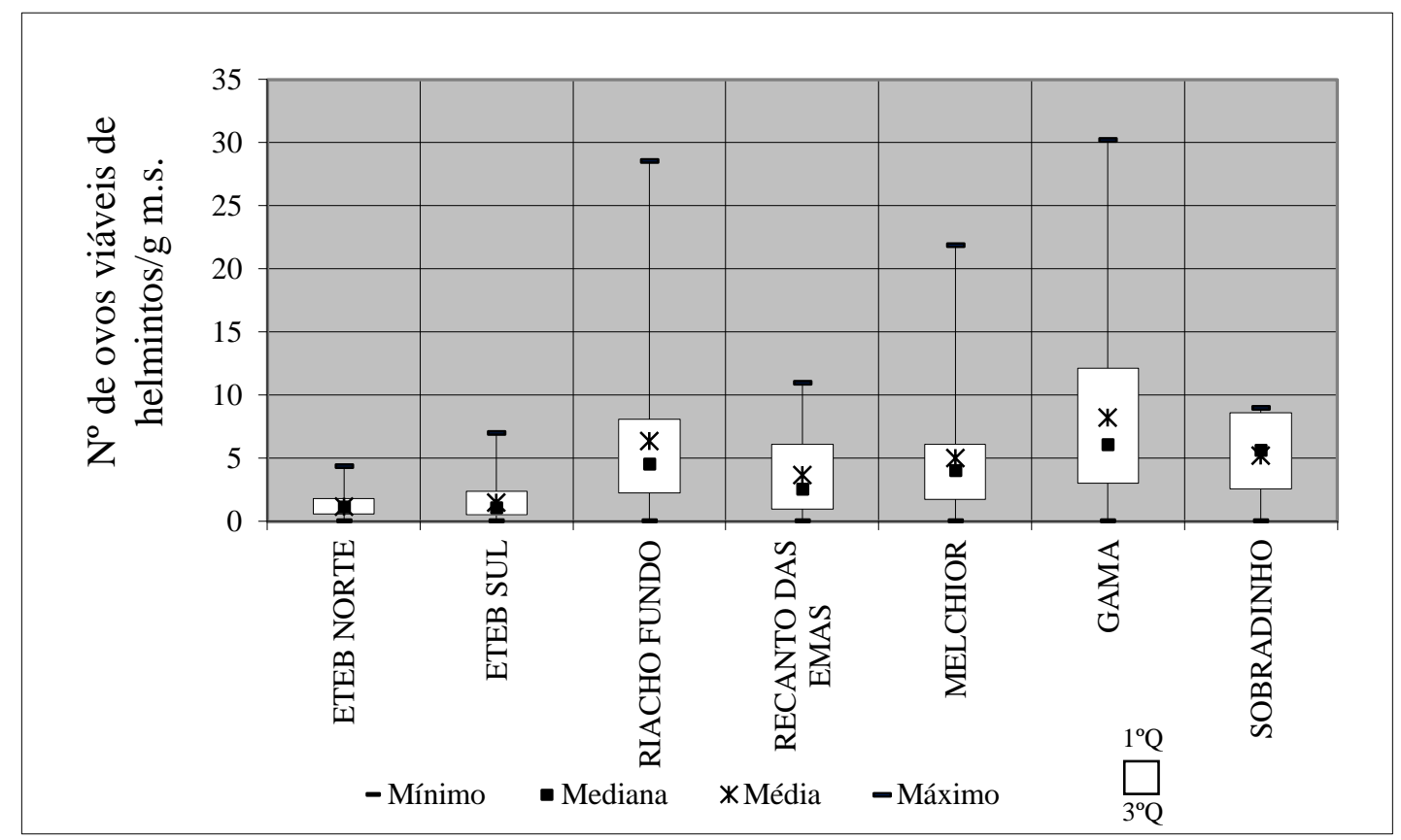

Figura 5.11 - Resultados de ovos de Helmintos viáveis nos lodos desaguados, gerados no Distrito Federal (2007 - 2014) - No de ovos viáveis de helmintos/g massa seca

Os processos de estabilização de lodo empregados nas ETEs do Distrito Federal são predominantemente anaeróbios, apenas na ETE Riacho Fundo o processo de estabilização se dá exclusivamente por digestão aeróbia, na ETEB Sul uma parcela do lodo é digerida aerobiamente e as estações Gama e Melchior produzem lodo aeróbio estabilizado proveniente dos reatores biológicos, assim, num total de 16 estações de tratamento de esgotos, 15 tratam, se não a totalidade, a maior parcela do lodo produzido, pela via anaeróbia, seja nos reatores UASB ou nos digestores anaeróbios.

Pode-se observar que a ETE Recanto das Emas é a que apresenta menor concentração de coliformes termotolerantes por massa seca de lodo desaguado, seguida da ETEB Norte.

Entre as possíveis causas para uma maior eficiência verificada nessas estações está o processo de estabilização do lodo, via digestão anaeróbia, da totalidade do lodo gerado. No caso específico da ETE Recanto das Emas, devido à necessidade de incremento na redução de sólidos no efluente das lagoas aeradas/facultativas, foi iniciada a dosagem de cal e sulfato de alumínio nessas unidades, o que pode explicar as menores densidades de coliformes e ovos de helmintos verificadas. A ETE Sobradinho, apesar de também empregar a digestão anaeróbia, não vem atingindo os mesmos patamares de eficiência, o que pode ser explicado pelas condicionantes operacionais atípicas, com sobrecarga 
orgânica da estação, produção elevada de lodo primário, devido ao condicionamento químico na etapa de decantação primária, com consequente redução do tempo de detenção no digestor.

Conforme Fernandes e Silva (2001), no caso da digestão anaeróbia, é esperada uma redução de duas ordens de magnitude para os coliformes fecais; entretanto, os ovos de helmintos são mais resistentes e não apresentam taxa de decaimento significativa. Com isso, a digestão anaeróbia do lodo, apesar de eficiente para diminuir o problema do mau odor, não atinge uma redução de patógenos que garanta a segurança sanitária do lodo, impondo limites ao uso do biossólido.

As ETEs do Distrito Federal não preveem nos fluxogramas de tratamento da fase sólida etapas para higienização do lodo. Dessa forma, considerando as concentrações reportadas na literatura para os lodos primário e secundário (Tabela 5.11) e a eficiência esperada da digestão anaeróbia, verifica-se uma baixa eficiência na redução de patógenos em todas as estações.

Tabela 5.11 - Concentração de bactérias no lodo primário e secundário, observadas nos Estados Unidos, em NMP/g m.s.

\begin{tabular}{lcc}
\hline \multicolumn{1}{c}{ Bactéria } & Lodo primário & Lodo secundário \\
\hline \hline Coliformes totais & $1,2 \times 10^{8}$ & $7,0 \times 10^{8}$ \\
\hline Coliformes termotolerantes & $2,0 \times 10^{7}$ & $8,3 \times 10^{6}$ \\
\hline Estreptococos & $8,9 \times 10^{5}$ & $1,7 \times 10^{6}$ \\
\hline Salmonella & $4,1 \times 10^{2}$ & $8,8 \times 10^{2}$ \\
\hline
\end{tabular}

Fonte: EPA (1985) apud Fernandes e Silva (2001)

A Resolução CONAMA N ${ }^{0}$ 375/2006 estabelece que a caracterização do lodo de esgoto ou produto derivado a ser aplicado na agricultura, quanto à presença de agentes patogênicos, será mediante a determinação de concentrações de coliformes termotolerantes, ovos viáveis de helmintos, salmonella e vírus entéricos. Com a Resolução CONAMA n³75/2006, o Conselho do Meio Ambiente do Distrito Federal - CONAM publicou, em 18 de Julho de 2006, a Resolução CONAM N 03/2006 que, atualmente, regulamenta os mecanismos e procedimentos para o uso agrícola do lodo de esgoto no Distrito Federal.

Ambas as resoluções, para fins de aplicação do lodo de esgotos na agricultura, propõem uma classificação dos lodos como classe A e B, segundo diferentes critérios de avaliação. No que se refere ao conteúdo de agentes patogênicos, as concentrações máximas 
admissíveis no lodo para enquadramento das classes foram mencionadas na Tabela 3.8. A Figura 5.12 mostra os resultados de concentração de bactérias do tipo coliformes termotolerantes nos dois últimos anos (2013 e 2014) em contraposição aos limites estabelecidos na resolução N³75/2006 - CONAMA.

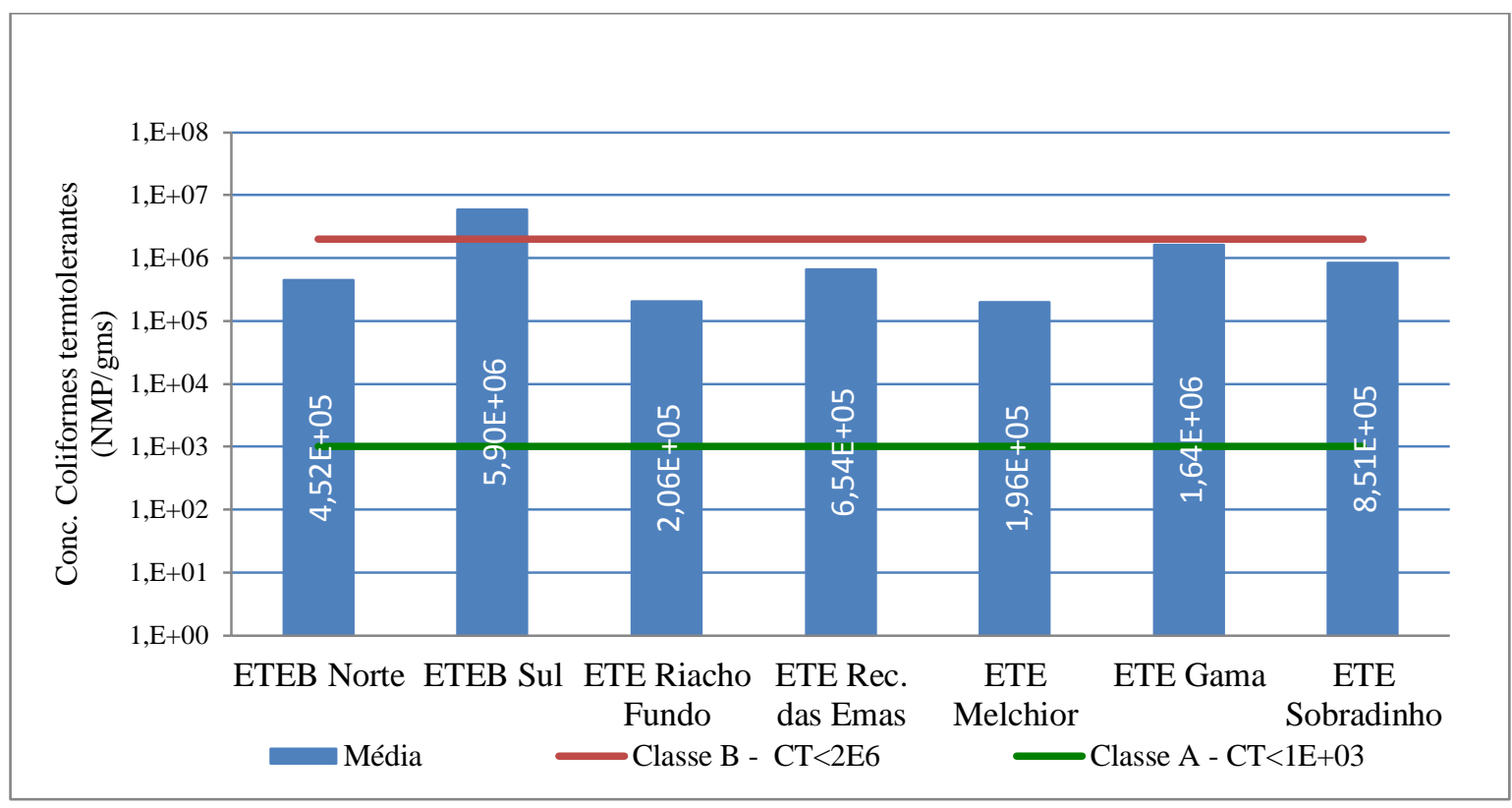

Figura 5.12 - Resultados de coliformes termotolerantes nos lodos desaguados gerados no Distrito Federal (2013 - 2014) - média anual.

Notas: (1) De maneira a uma classificação do lodo com dados mais recentes, foram utilizados dados de concentração apenas dos anos 2013 e 2014.

(2) Os dados da ETE Recanto das Emas referem-se a análises de 2012;

(3) Os dados da ETE Sobradinho referem-se a análises de 2009.

Nota-se pelas Figuras 5.11 e 5.12 que, segundo o que preconiza a legislação aplicável mencionada, nenhuma estação do Distrito Federal produz lodo Classe A, a ETEB Sul, responsável por $54,7 \%$ dos lodos gerados no DF, não atende os limites estabelecidos para classe B, as demais ETEs, considerando os parâmetros analisados (coliformes termotolerantes e ovos viáveis de helmintos) geram lodos classe $\mathrm{B}$, o que corresponde à 45,3\% da produção de lodo desaguado no Distrito Federal anualmente.

A determinação dos parâmetros salmonella e vírus entéricos não faz parte da rotina de monitoramento das ETEs do DF, no laboratório de microbiologia da CAESB. No caso específico dos lodos investigados, como nenhum atendeu as exigências para lodo Classe A, 
a concentração de bactérias do tipo Salmonella e vírus entéricos, exclusivas para a definição dessa classe, não foi determinante para a classificação do lodo.

Nesta etapa do diagnóstico, objetivou-se que o modelo de tratamento de esgotos adotado pela CAESB, com a implantação de ETEs para localidades distintas, permitisse identificar a correlação entre os fatores socioambientais, mencionados inicialmente, e a concentração dos microrganismos nos esgotos, principalmente naqueles casos em que o perfil socioeconômico da população estivesse bem delineado. Para tanto, de maneira simplificada, procurou-se estabelecer um paralelo entre o perfil socioeconômico e a qualidade sanitária do lodo produzido, utilizando dados do IBGE relativos ao indicador de desenvolvimento humano - IDH, por Região Administrativa - RA, segundo as bacias de contribuição de esgotos para cada ETE. Os resultados obtidos dessa avaliação são mostrados na Figura 5.13.

Outros indicadores, como os indicadores epidemiológicos (mortalidade infantil, mortalidade até cinco anos por doenças diarreicas e a morbidade até cinco anos por doenças diarreicas) citados por Costa et. al. (2007) como apropriados para representar os efeitos da insuficiência das ações de saneamento sobre a saúde humana, não puderam ser usados nesse contexto, visto que os dados encontrados referem-se ao Distrito Federal e não estão distribuídos por RA. Da mesma maneira, a incidência de verminoses na população do Distrito Federal e de doenças de veiculação hídrica não está disponível por região administrativa, impossibilitando o seu cruzamento com os dados de qualidade sanitária dos lodos.

Um estudo elaborado pela CODEPLAN analisou a evolução do Índice de Desenvolvimento Humano (IDH) no Distrito Federal: 0,616 (1999); 0,725 (2000) e 0,824 (2010) e revelou que o Distrito Federal apresentou o melhor índice entre as 27 unidades federativas, tendo sido a única classificada como IDH muito alto. Dados divulgados pela CODEPLAN referentes à 2003, apresentam esse indicador por Região Administrativa. Esses dados foram utilizados para compor um IDH ponderado, em função da população atendida, entre as RAs que compõem a bacia de contribuição de cada ETE (Tabela 5.12) e foram analisados em conjunto com as concentrações de ovos viáveis de helmintos levantadas (Figura 5.13). 
Tabela 5.12 - Indicador de Desenvolvimento Humano - IDH do Distrito Federal, distribuído por Região Administrativa, ano 2003

\begin{tabular}{|c|c|c|c|c|}
\hline ETE & Região Administrativa & População & IDH & $\mathrm{IDH}_{\text {ponderado }}$ \\
\hline \multirow{12}{*}{ ETEB SUL } & Brasília (Asa Sul) & 109.673 & 0,936 & \multirow{12}{*}{0,897} \\
\hline & Águas Claras $^{1}$ & 87.080 & 0,867 & \\
\hline & Núcleo Bandeirante & 22.569 & 0,853 & \\
\hline & Candangolândia & 15.886 & 0,853 & \\
\hline & Guará & 107.580 & 0,867 & \\
\hline & Cruzeiro & 31.230 & 0,928 & \\
\hline & Sudoeste/Octogonal $^{2}$ & 51.565 & 0,936 & \\
\hline & SIA $^{2}$ & 2.388 & 0,936 & \\
\hline & Lago Sul & 23.020 & 0,945 & \\
\hline & Jardim Botânico & 988 & 0,936 & \\
\hline & Águas Claras (metrô) ${ }^{1}$ & 34.832 & 0,867 & \\
\hline & Park Way & 817 & 0,933 & \\
\hline \multirow{4}{*}{ ETEB NORTE } & Brasília (Asa Norte) & 99.770 & 0,936 & \multirow{4}{*}{0,898} \\
\hline & Lago Norte & 28.956 & 0,933 & \\
\hline & Varjão $^{3}$ & 8.998 & 0,761 & \\
\hline & Estrutural $^{3}$ & 25.770 & $\overline{0,761}$ & \\
\hline ETE RIACHO FUNDO & Riacho fundo & 34.055 & 0,826 & 0,826 \\
\hline ETE TORTO & Vila Roriz & 1.226 & & \\
\hline ETE SOBRADINHO & Sobradinho & 83.809 & 0,837 & 0,837 \\
\hline ETE PLANALTINA & & 114.437 & 0,764 & 0,764 \\
\hline ETE V.AMANHECER & & 19.834 & 0,764 & 0,764 \\
\hline \multirow{2}{*}{ ETE PARANOÁ } & Paranoá & 40.047 & 0,785 & \multirow{2}{*}{0,771} \\
\hline & Itapoã $^{4}$ & 56.168 & 0,761 & \\
\hline ETE S. SEBASTIÃO & São Sebastião & 75.817 & 0,820 & 0,820 \\
\hline ETE GAMA & Gama & 121.509 & 0,815 & 0,815 \\
\hline ETE S. MARIA & Santa Maria & 41.771 & 0,794 & 0,794 \\
\hline ETE ALAGADO & Santa Maria & 77.673 & 0,794 & 0,794 \\
\hline \multirow{2}{*}{ ETE REC EMAS } & Recanto das Emas & 124.605 & 0,775 & \multirow{2}{*}{0,772} \\
\hline & Riacho Fundo II & 36.373 & 0,761 & \\
\hline ETE SAMAMBAIA & Samambaia & 191.818 & 0,781 & 0,781 \\
\hline \multirow{4}{*}{ ETE MELCHIOR } & Taguatinga & 197.783 & 0,856 & \multirow{4}{*}{0,817} \\
\hline & Ceilândia & 322.500 & 0,784 & \\
\hline & Vicente Pires $^{1}$ & 4.501 & $\overline{0,867}$ & \\
\hline & Águas Claras (Parque) $^{1}$ & 52.248 & 0,867 & \\
\hline ETE BRAZLANDIA & Brazlândia & 44.629 & 0,761 & 0,761 \\
\hline
\end{tabular}

Fonte: Adaptado de CODEPLAN (2003)

Notas:(1) Região Administrativa não havia sido criada em 2003, por similaridade regional, admitiu-se o IDH da RA do Guará;

(2) Região Administrativa não havia sido criada em 2003, faziam parte da RA Brasília;

(3) Região Administrativa não havia sido criada em 2003, por similaridade do perfil socioeconomico, admitiu-se o IDH mais baixo do DF, da RA de Brazlândia;

(4) Região Administrativa não havia sido criada em 2003, por similaridade regional, admitiu-se o IDH da RA do Paranoá; 


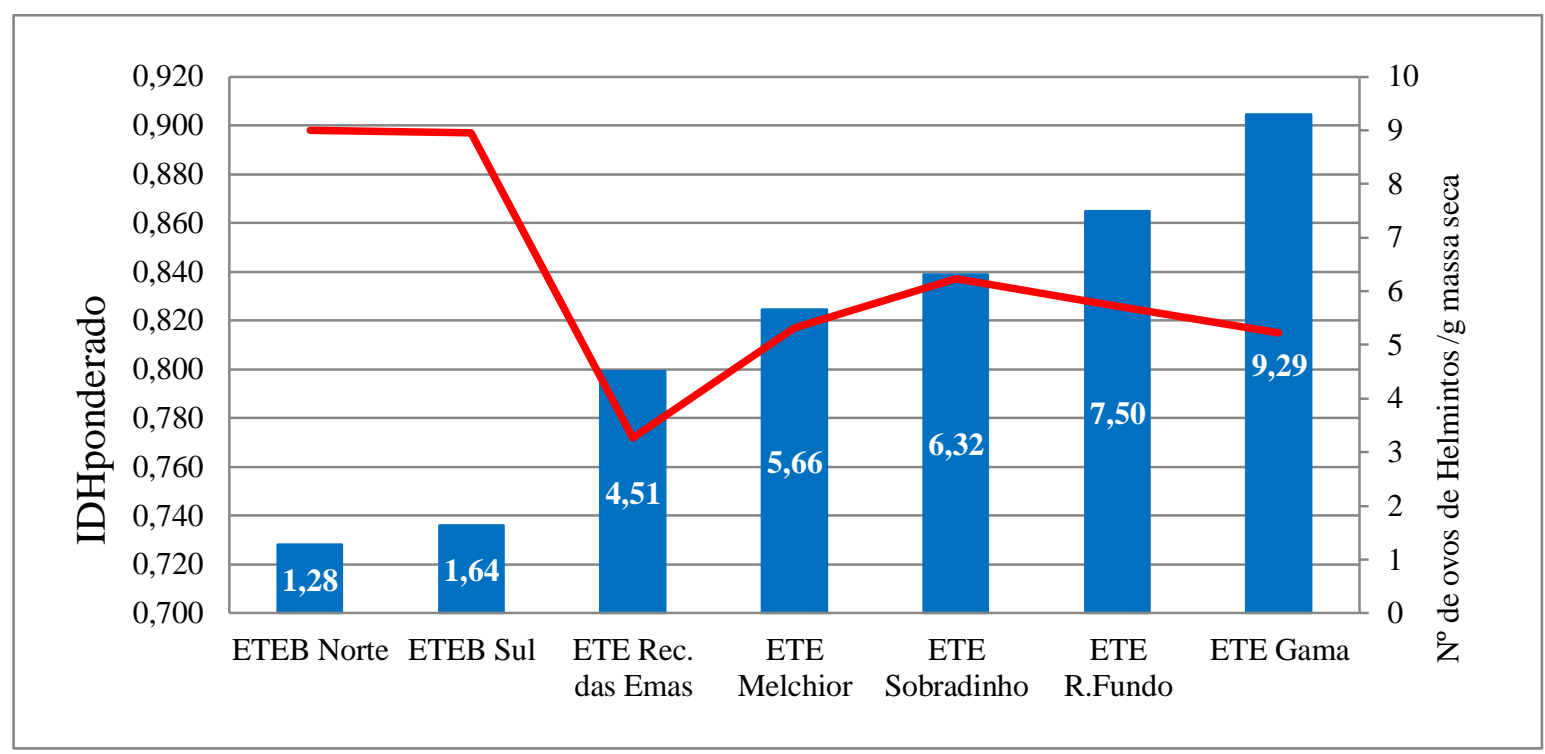

Figura 5.13 - Resultados de parasitologia dos lodos desaguados, gerados no Distrito Federal (2007 - 2014) - Correlação de $\mathrm{N}^{\text {o }}$ de ovos de helmintos/g m.s. e IDH.

Nota-se pela visualização da Figura 5.13, que a sobreposição das informações disponíveis, apesar de carente de indicadores mais expressivos, como esperado, sugere uma correlação entre o fator socioeconômico, expresso pelo IDH, e a concentração de ovos de helmintos nos lodos das estações do DF, em que se verifica que quanto mais elevado o IDH da bacia de contribuição, menor a concentração de ovos de helmintos nos lodos daquela ETE.

\subsubsection{Características físico-químicas dos lodos gerados nas ETEs do Distrito Federal}

A definição da alternativa mais adequada à disposição final do lodo deve estar fundamentada, entre outros fatores, em uma análise de suas características microbiológicas e físico-químicas. No caso da composição físico-química, têm relevante importância a quantidade de matéria orgânica, os nutrientes, os metais pesados e os compostos orgânicos potencialmente tóxicos.

No presente diagnóstico foram levantadas as informações quanto à composição do lodo, a partir de pesquisas realizadas com o lodo de ETEs do Distrito Federal, bem como dados disponíveis na CAESB, que, além dos parâmetros de controle de qualidade para monitoramento do processo de tratamento, dispunha dos dados de caracterização do lodo para atendimento às exigências das Resoluções CONAMA no 375/2006 e Resolução CONAM/DF n ${ }^{\circ}$ 03/2006, realizados em duas campanhas.

As informações levantadas foram compiladas e são apresentadas nas Tabelas 5.13 e 5.14 . 
Tabela 5.13 - Composição dos lodos de esgotos gerados nas ETEs do DF quanto aos parâmetros agronômicos, expressos em base seca.

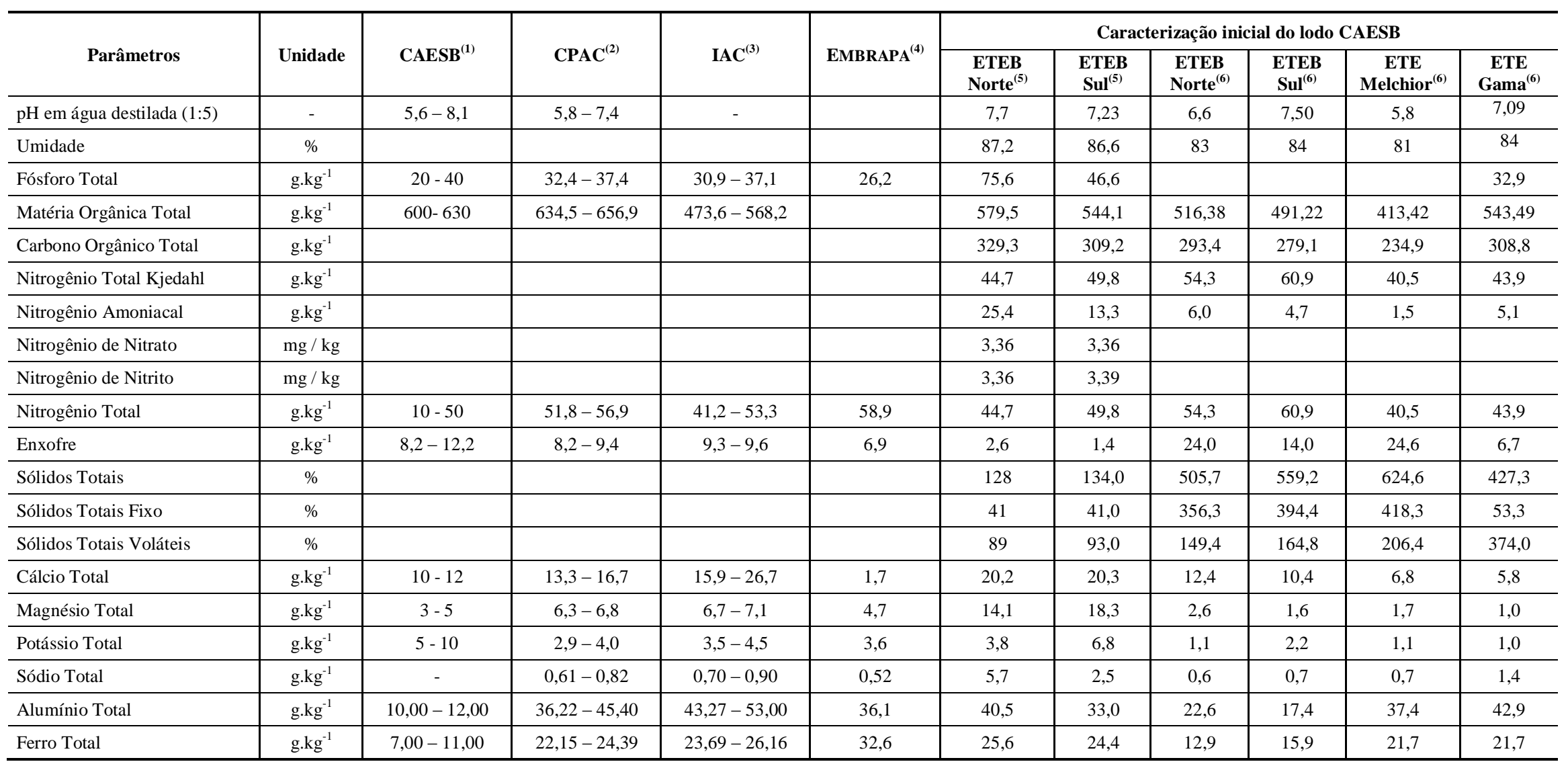

Fonte: Adaptado de Silva et al. (2002), Lemainski e Silva (2006), Souza et al. (2009) e CAESB (2014)

Notas:

(1) CAESB - Companhia de Saneamento Ambiental do (3) Instituto Agronômico de Campinas (biossólido seco: teor Distrito Federal, caracterização de lodo apresentada por Silva

de água $-100 \mathrm{~g} / \mathrm{kg}$; média de duas amostras)

5) Plano de caracterização de lodo desaguado, realizado em et al. (2002)

$\begin{array}{llll}\text { et al. (2002) } & \text { (4) Embrapa - Laboratório do Centro de Pesquisa (6) Plano de caracterização de lodo desaguado realizado e } \\ \text { (2) Laboratório do Centro de Pesquisa Agropecuária dos } & \text { Agropecuária dos Cerrados, caracterização apresentada por 2012, pelo laboratório São Lucas, contratado da CAESB }\end{array}$ 2009, em laboratório contratado pela CAESB

Cerrados - Embrapa (biossólido seco: teor de água $100 \mathrm{~g} / \quad$ Souza et al.(2009)

$\mathrm{kg}$; média de seis amostras) 
Tabela 5.14 - Composição dos lodos de esgotos gerados nas ETEs do DF quanto às substâncias inorgânicas, expressos em base seca

\begin{tabular}{|c|c|c|c|c|c|c|c|c|c|c|c|c|c|}
\hline \multirow[b]{2}{*}{ Parâmetros } & \multirow[b]{2}{*}{ Unidade } & \multirow[b]{2}{*}{ CAESB $^{(1)}$} & \multirow[b]{2}{*}{ CPAC $^{(2)}$} & \multirow[b]{2}{*}{$\mathbf{I A C}^{(3)}$} & \multirow[b]{2}{*}{ EMBRAPA $^{(4)}$} & \multicolumn{8}{|c|}{ Concentração (base seca) } \\
\hline & & & & & & $\begin{array}{l}\text { ETEB } \\
\text { Norte }^{5}\end{array}$ & ETEB Sul ${ }^{5}$ & $\begin{array}{c}\text { ETE } \\
\text { Melchior }^{5}\end{array}$ & ETE Gama $^{5}$ & $\begin{array}{l}\text { ETEB } \\
\text { Norte }^{6}\end{array}$ & ETEB Sul ${ }^{6}$ & $\begin{array}{c}\text { ETE } \\
\text { Melchior }^{6}\end{array}$ & ETE Gama $^{6}$ \\
\hline Antimônio Total & $\mathrm{mg} / \mathrm{kg}$ & & & & & ND & ND & ND & 32,30 & ND & ND & ND & 2,36 \\
\hline Arsênio Total & $\mathrm{mg} / \mathrm{kg}$ & - & - & $<0,1$ & & ND & ND & ND & 3,36 & ND & ND & ND & 5,33 \\
\hline Bário Total & $\mathrm{mg} / \mathrm{kg}$ & & & & & 129,3 & 90,8 & 101,3 & 104,10 & 63,48 & 51,31 & 81,96 & 82,28 \\
\hline Cádmio Total & $\mathrm{mg} / \mathrm{kg}$ & $<2$ & - & $2,3-2,5$ & & 3,78 & 3,81 & 1,87 & 2,83 & ND & ND & ND & ND \\
\hline Cobre Total & $\mathrm{mg} / \mathrm{kg}$ & $70-85$ & $126-243$ & $138-156$ & 155,4 & 247,90 & 169,49 & 209,54 & 504,4 & 83,01 & 66,24 & 75,17 & 86,15 \\
\hline Chumbo Total & $\mathrm{mg} / \mathrm{kg}$ & 50 & - & $90,4-95,6$ & & 29,41 & 33,90 & 99,59 & 28,30 & 14,32 & 19,91 & 23,41 & 25,94 \\
\hline Cromo Total & $\mathrm{mg} / \mathrm{kg}$ & $48-56$ & - & $33,2-39,6$ & & 33,61 & 38,14 & 53,94 & 37,73 & 34,18 & 44,53 & 59,39 & 39,41 \\
\hline Mercúrio Total & $\mathrm{mg} / \mathrm{kg}$ & 4 & - & $<0,1$ & & 8,18 & 1,22 & 1,23 & ND & 1,83 & 1,78 & 1,53 & 1,26 \\
\hline Molibdênio Total & $\mathrm{mg} / \mathrm{kg}$ & - & - & $<0,1$ & & ND & ND & ND & 20,70 & 4,46 & 3,47 & 4,16 & 8,92 \\
\hline Níquel Total & $\mathrm{mg} / \mathrm{kg}$ & $2,5-5,2$ & - & $12,7-19,1$ & & 21,01 & 21,19 & 10,37 & 15,72 & 11,79 & 12,52 & 13,47 & 10,19 \\
\hline Selênio Total & $\mathrm{mg} / \mathrm{kg}$ & - & - & $<0,1$ & & ND & $\mathrm{ND}$ & ND & 16,80 & ND & ND & ND & 115,03 \\
\hline Zinco Total & $\mathrm{mg} / \mathrm{kg}$ & $320-350$ & $676-733$ & $594-624$ & 536,4 & 760,5 & 796,61 & $1.906,6$ & 522,01 & 312,56 & 284,86 & 317,82 & 448,58 \\
\hline Manganês & $\mathrm{mg} / \mathrm{kg}$ & $79-81$ & $83-124$ & $116-138$ & 46,7 & & & & & & & & 45,59 \\
\hline Boro & $\mathrm{mg} / \mathrm{kg}$ & - & $13,3-26,1$ & $13,6-17,1$ & 7,4 & ND & ND & ND & 29,70 & & & & ND \\
\hline
\end{tabular}

Fonte: Adaptado de Silva et al. (2002a), Lemainski e Silva (2006) e CAESB (2014)

Notas:

(1) CAESB - Companhia de Saneamento Ambiental do (3) Instituto Agronômico de Campinas (biossólido seco: teor Distrito Federal, caracterização de lodo apresentada por Silva de água $-100 \mathrm{~g} / \mathrm{kg}$; média de duas amostras)

(5) Plano de caracterização de lodo desaguado, realizado em et al. (2002)

(4) Embrapa - Laboratório do Centro de Pesquisa

(2) Laboratório do Centro de Pesquisa Agropecuária dos , em laboratório contratado pela CAESB

Cerrados - Embrapa (biossólido seco: teor de água $100 \mathrm{~g} / \mathrm{kg} ; \quad$ Souza et al.(2009)

média de seis amostras) 
A análise da composição dos lodos de esgoto das ETEs do DF monitoradas mostra teores de matéria orgânica, macronutrientes ( $\mathrm{N}, \mathrm{P}$ e K) e micronutrientes $(\mathrm{Zn}, \mathrm{Cu}, \mathrm{Fe}, \mathrm{Mn}$ e $\mathrm{Mo})$, que são os parâmetros de interesse para uso agrícola, similares entre as diferentes estações, ao longo do tempo, visto que os dados se referem a análises do lodo em períodos distintos ao longo dos últimos anos.

Quando comparado à composição dos lodos de outras estações no Brasil, segundo a Tabela 5.15 e Figuras 5.14 a 5.17, nos lodos das estações do DF monitoradas, tanto a matéria orgânica quanto os macronutrientes são encontrados em concentrações mais elevadas que em quase todas as demais ETEs elencadas. Destaque maior para o fósforo, que apresenta teor médio acima de todas as demais estações em quase todos os experimentos, o que poderia ser explicado, entre outros fatores, pelas tecnologias de tratamento de esgotos empregadas nas ETEs do DF monitoradas, que se caracterizam pela remoção de nutrientes, o que, por sua vez, propicia a concentração desse composto no lodo.

Tabela 5.15 - Composição de lodo de esgotos em diversas ETEs no Brasil

\begin{tabular}{|c|c|c|c|c|c|c|c|c|c|}
\hline \multirow[t]{2}{*}{ ETE } & $\begin{array}{c}\text { Materia } \\
\text { Orgânica }\end{array}$ & N - total & $\mathbf{P}$ & $\mathbf{K}$ & $\mathrm{Ca}$ & Mg & $\mathbf{Z n}$ & $\mathbf{C u}$ & $\mathbf{F e}$ \\
\hline & \multicolumn{9}{|c|}{ 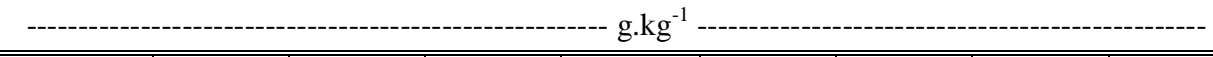 } \\
\hline Barueri & 440,00 & 22,50 & 14,80 & 0,10 & 72,90 & & 0,99 & 0,35 & 15,12 \\
\hline Barueri & 302,72 & 19,00 & 9,00 & 2,00 & 86,00 & 4,00 & 16,32 & 9,00 & 55,06 \\
\hline Bichoró & 714,00 & 48,40 & 28,90 & 1,00 & 6,30 & 2,40 & 0,56 & 0,23 & 69,35 \\
\hline Humaitá & 634,00 & 41,00 & 6,00 & 1,50 & 19,50 & 2,70 & 0,55 & 0,14 & 8,06 \\
\hline Bertioga & 683,00 & 59,30 & 26,00 & 3,50 & 13,00 & 3,70 & 0,44 & 0,14 & 66,62 \\
\hline Suzano & 410,00 & 23,10 & 26,50 & 1,00 & 146,00 & 2,20 & 2,71 & 0,54 & 40,45 \\
\hline Franca & 652,00 & 55,30 & 9,30 & 2,60 & 20,00 & 2,20 & 1,56 & 0,16 & 12,00 \\
\hline Lava-pés & 526,00 & 45,00 & 25,90 & 3,90 & 133,00 & 2,70 & 0,68 & 0,12 & 10,46 \\
\hline Campina Grande & 496,60 & 41,30 & 22,80 & 4,60 & 14,40 & 20,30 & - & - & - \\
\hline Araçatuba & 194,17 & 71,26 & 18,79 & 15,14 & 11,06 & 3,44 & - & - & 0,96 \\
\hline Jundiaí & 538,56 & 31,80 & 17,20 & 1,80 & 12,50 & 2,20 & 2,15 & 0,81 & 31,65 \\
\hline V.Leopoldina & 317,40 & 12,60 & 26,00 & 3,10 & - & - & 8,68 & 1,04 & - \\
\hline
\end{tabular}

Fonte: Adaptado de Tsutya (2001a), Pedroza et al. (2005), Barbosa et al. (2007), Campos e Alves (2008), Corrêa et al. (2008), Lira et al. (2008)

No caso do nitrogênio, especial ênfase é dada à ETE Barueri, Suzano e Vila Leopoldina, pelos baixos teores encontrados. O tratamento do lodo com cal, que ocorre nessas estações, pode ser uma das causas para essa característica, visto que a cal eleva a temperatura e com 
isso há uma perda de $\mathrm{N}$-amoniacal e $\mathrm{N}$-orgânico de baixo peso molecular pela sua volatilização.



Figura 5.14 - Concentração de Nitrogênio em experimentos com lodo de ETEs do DF x ETEs brasileiras

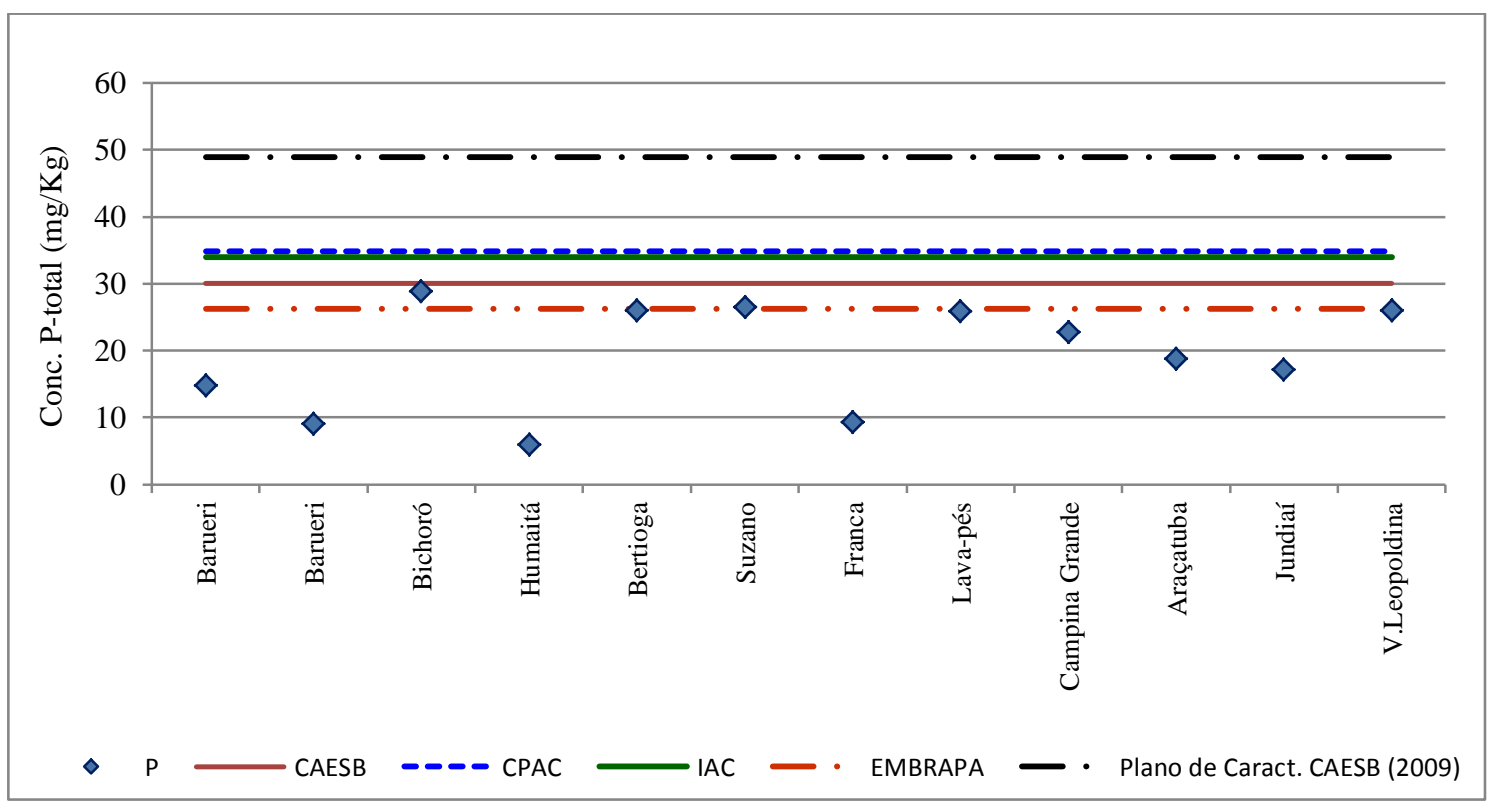

Figura 5.15 - Concentração de Fósforo em experimentos com lodo de ETEs do DF, comparadas a algumas ETEs brasileiras 


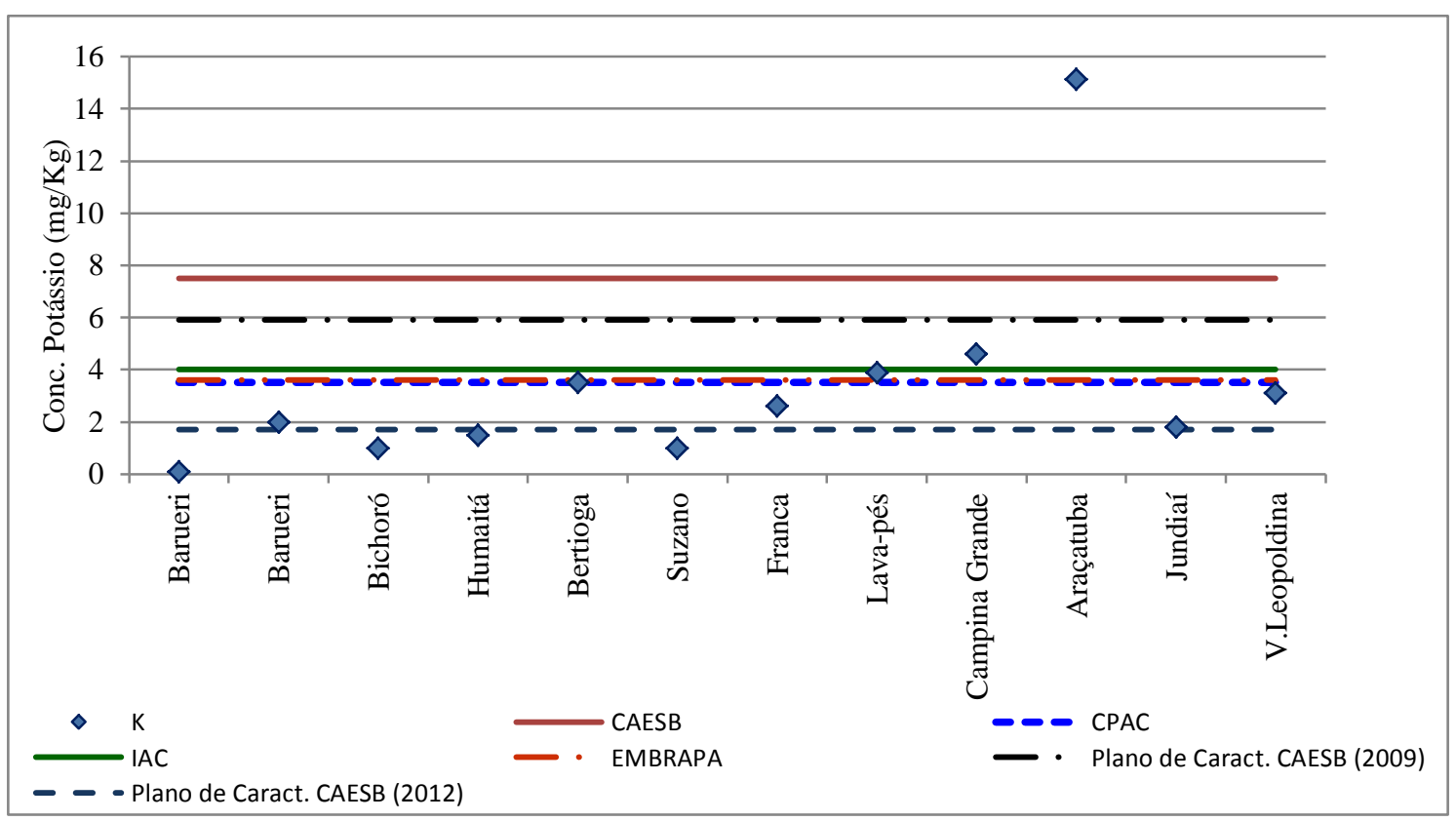

Figura 5.16 - Concentração de Potássio em experimentos com lodo de ETEs do DF comparadas a algumas ETEs brasileiras

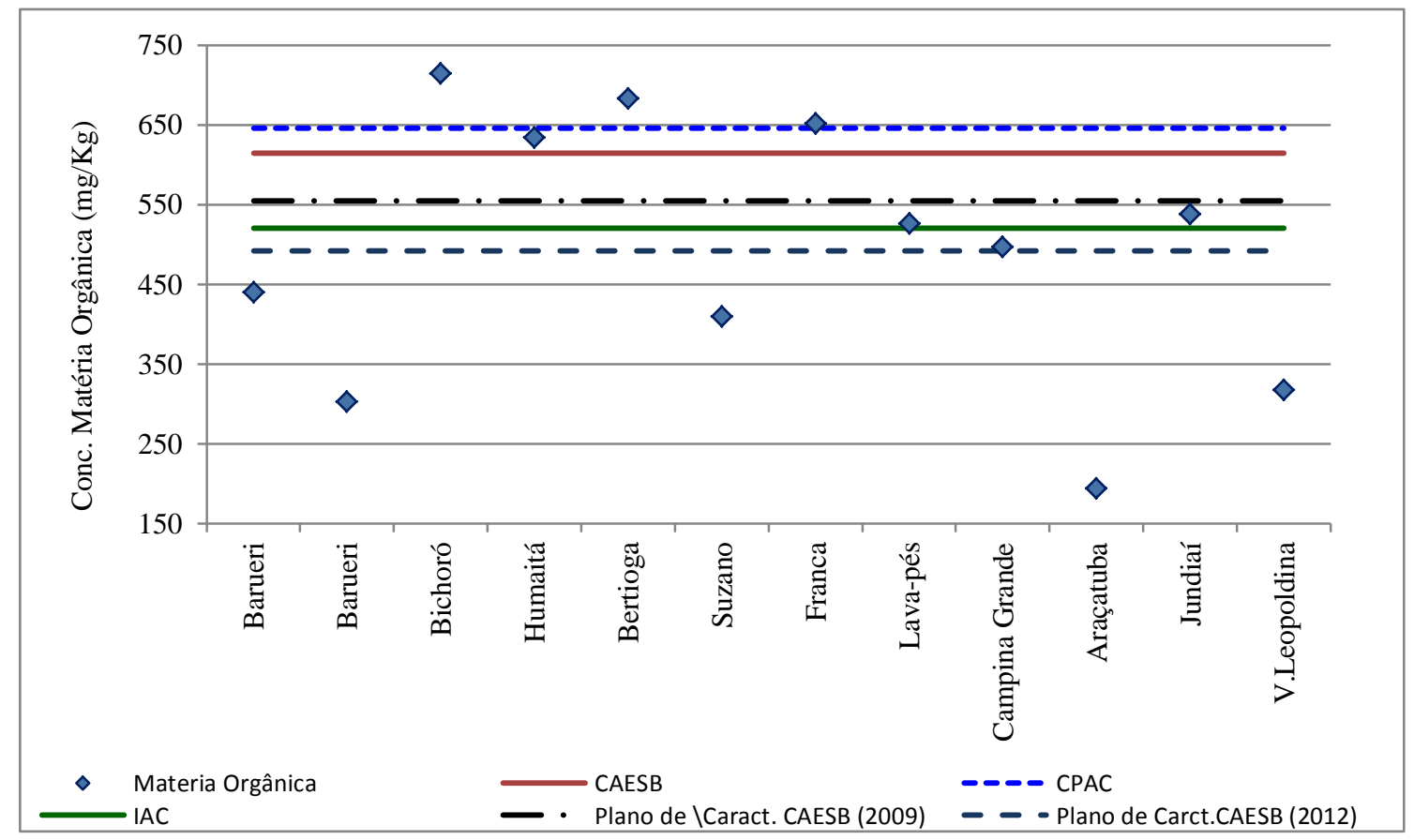

Figura 5.17 - Concentração de Matéria Orgânica em experimentos com lodo de ETEs do DF x ETEs brasileiras

No caso dos micronutrientes (Figuras 5.18 a 5.22), os lodos provenientes das ETEs do Distrito Federal, frente a outras estações no Brasil, apresentam baixos teores de zinco e cobre, elementos cuja presença nos esgotos pode ser associada principalmente a processos 
industriais como fabricação de tintas, borracha, produtos farmacêuticos, pilhas elétricas, indústria têxtil, galvanoplastia. Isso poderia justificar essa característica do lodo, visto que o Distrito Federal não possui polos industriais de proeminência.

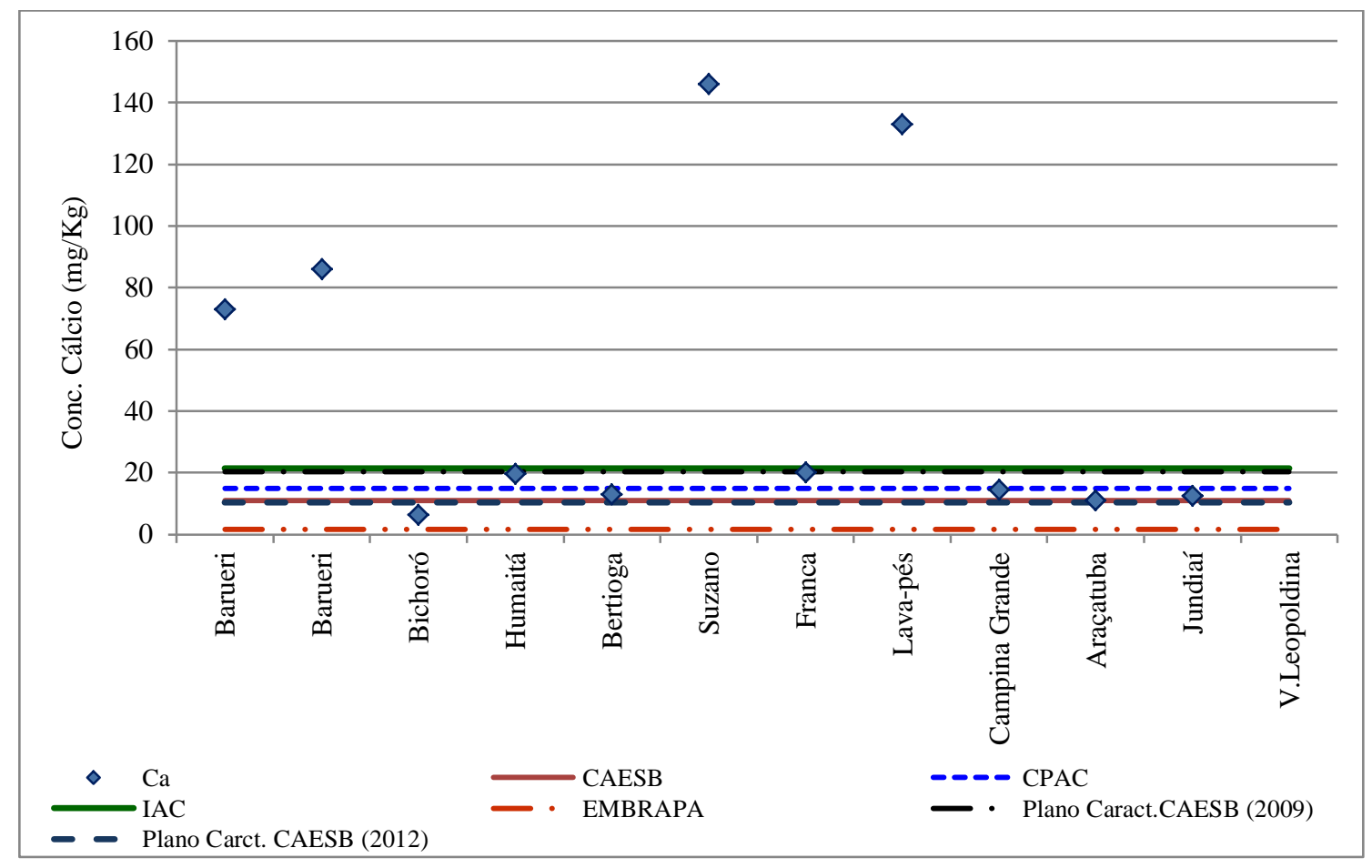

Figura 5.18 - Concentração de Cálcio em experimentos com lodo de ETEs do DF x ETEs brasileiras

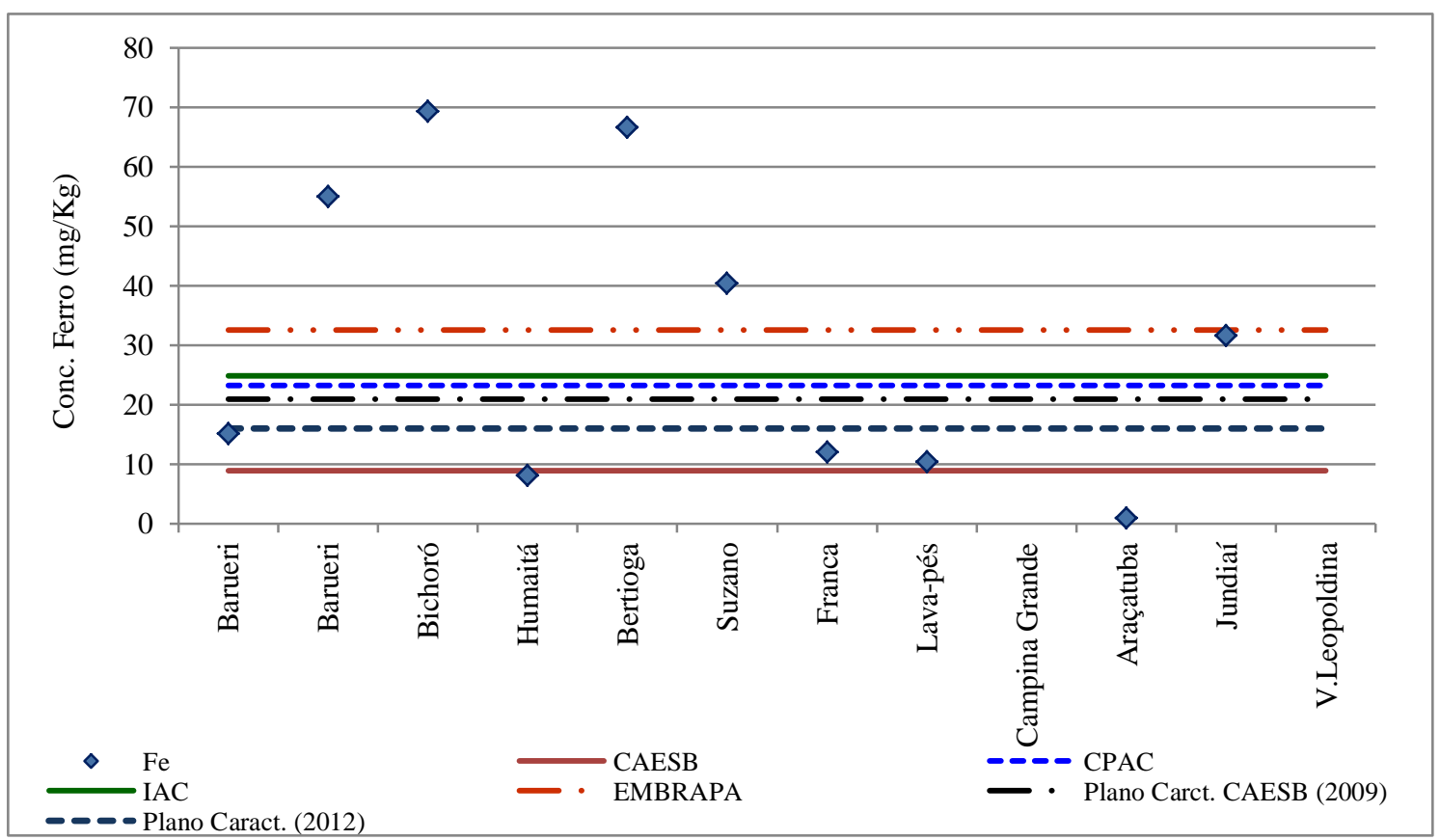

Figura 5.19 - Concentração de Ferro em experimentos com lodo de ETEs do DF x ETEs brasileiras 


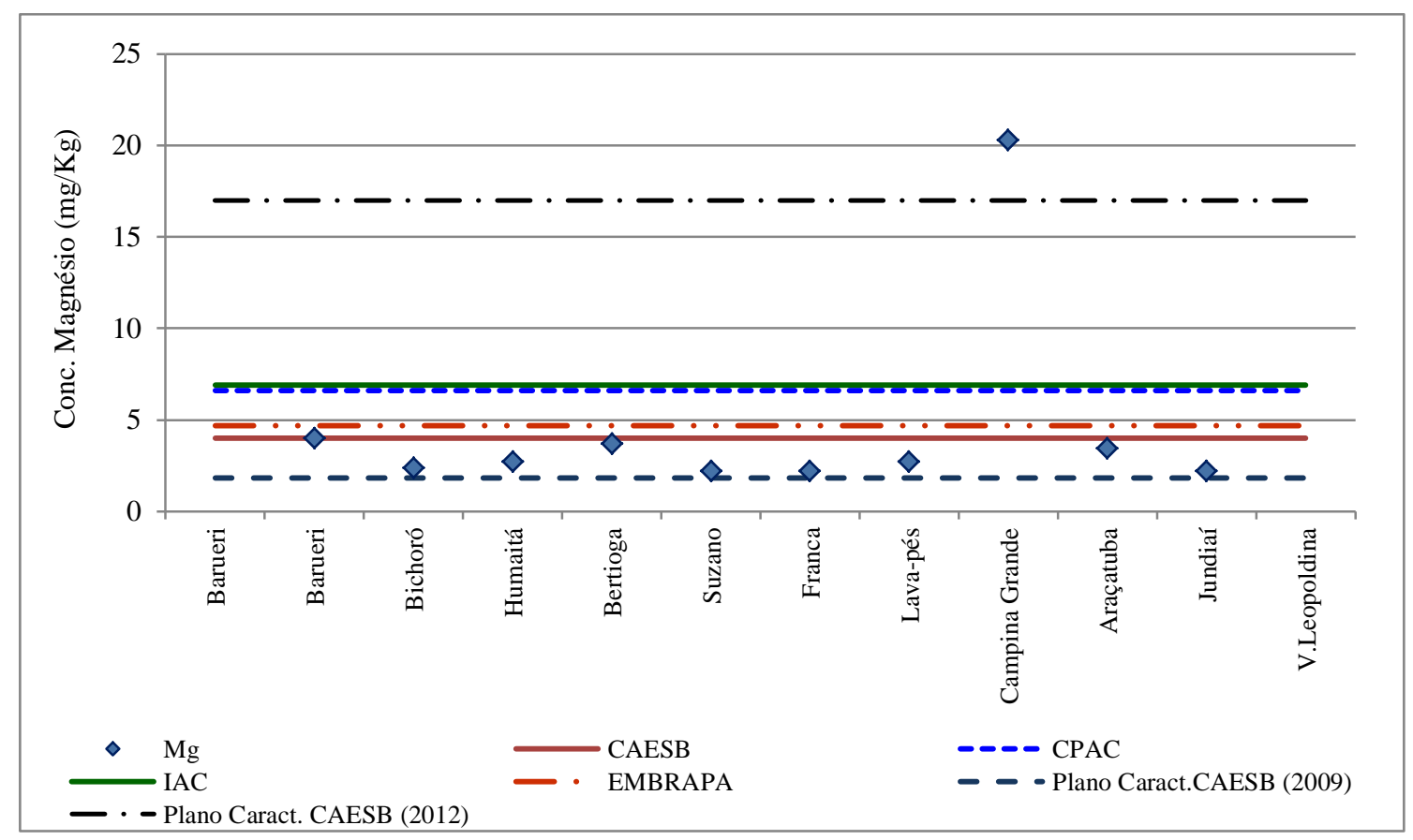

Figura 5.20 - Concentração de Magnésio em experimentos com lodo de ETEs do DF x ETEs brasileiras

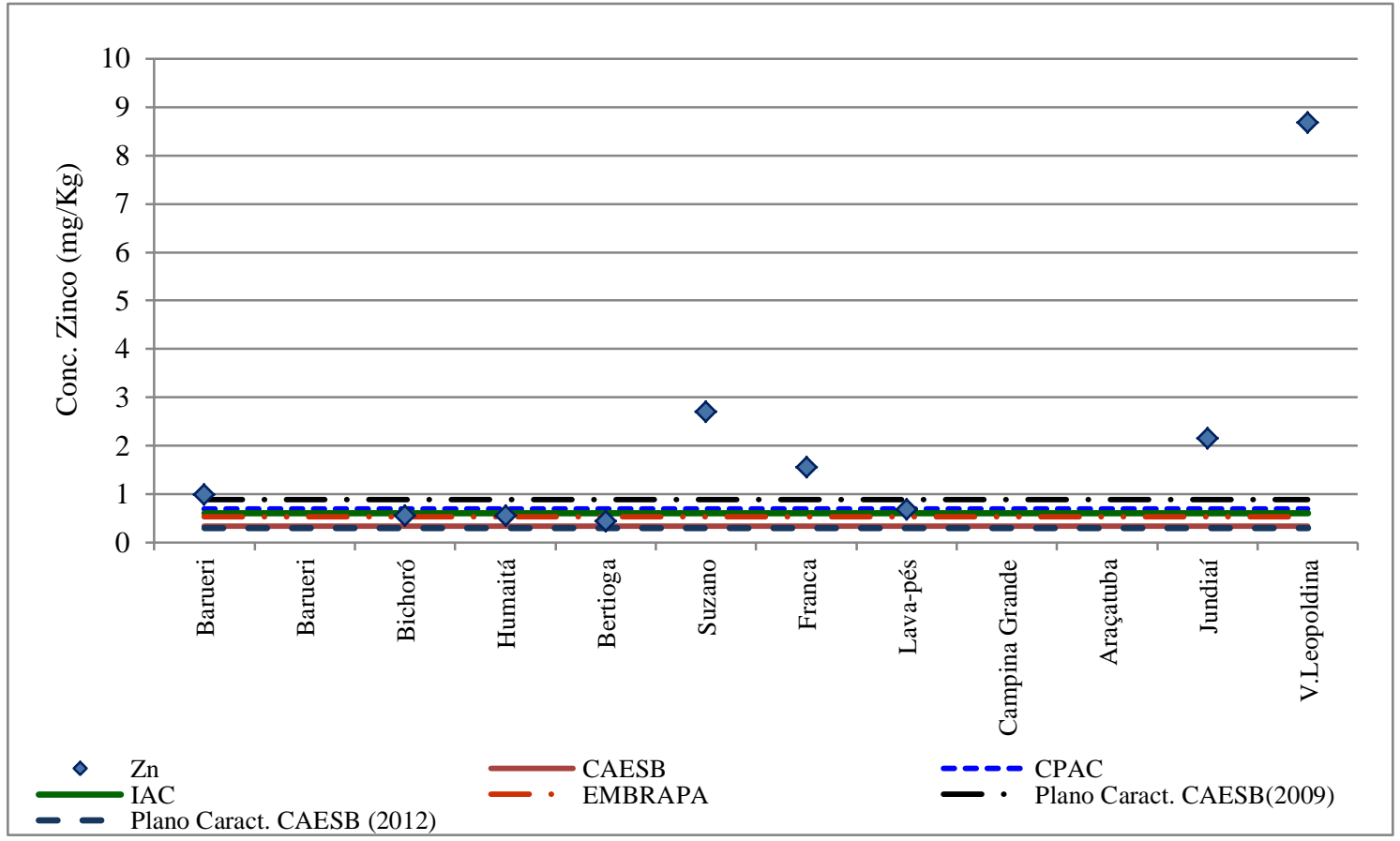

Figura 5.21 - Concentração de Zinco em experimentos com lodo de ETEs do DF x ETEs brasileiras 


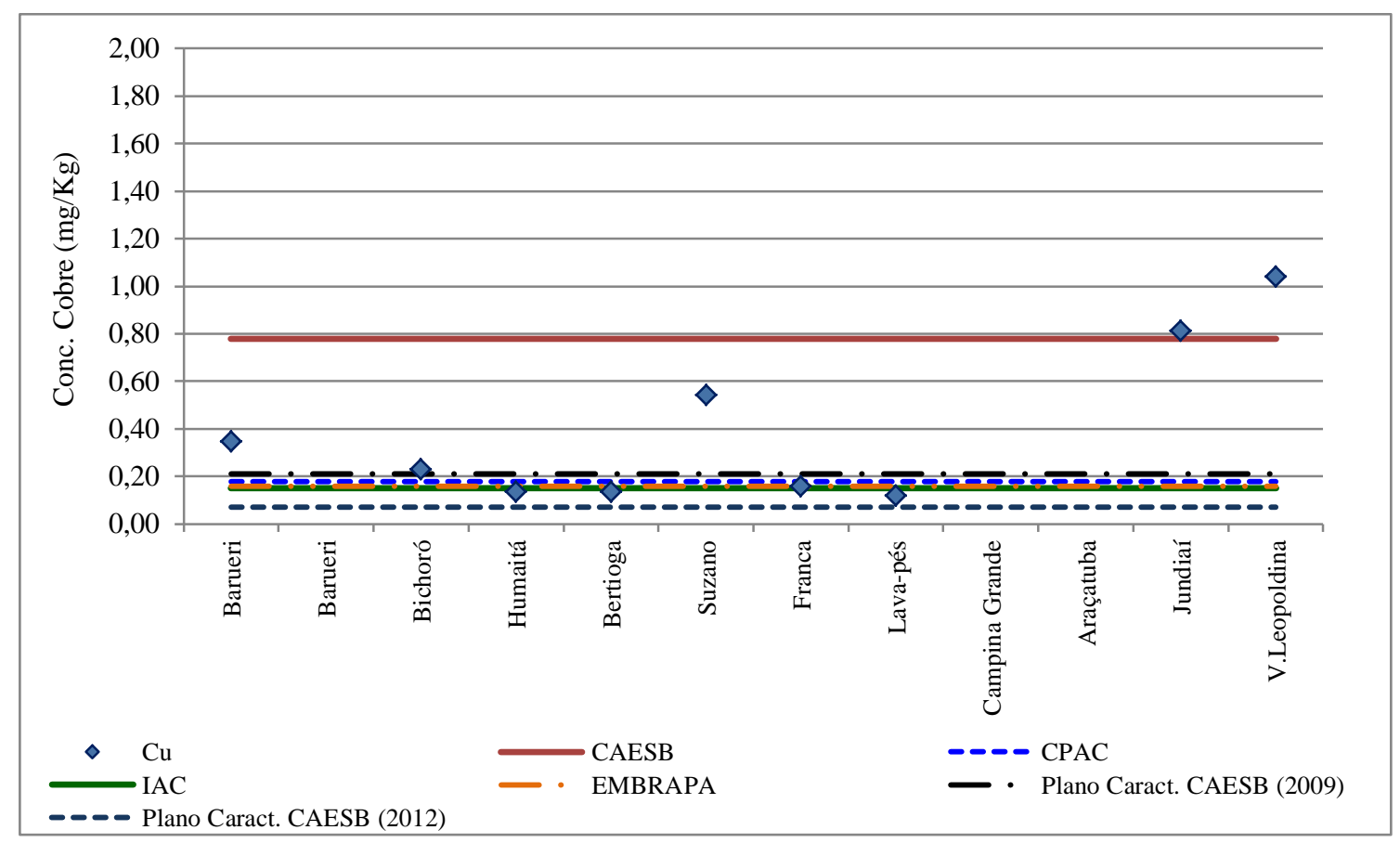

Figura 5.22 - Concentração de Cobre em experimentos com lodo de ETEs do DF x ETEs brasileiras

Em relação à concentração de metais pesados a Tabela 5.14 mostra que nos lodos das ETEs Brasília Sul, Brasília Norte, Gama e Melchior, responsáveis por 92,5\% da produção anual de lodo no Distrito Federal. Os resultados mostraram baixos teores dos metais As, $\mathrm{Cu}, \mathrm{Pb}, \mathrm{Cd}, \mathrm{Mn}, \mathrm{Se}, \mathrm{Ni}, \mathrm{Hg}, \mathrm{Ba}, \mathrm{Sb}, \mathrm{B}, \mathrm{Mo}$ e $\mathrm{Zn}$, o que decorre, principalmente da característica doméstica dos esgotos do Distrito Federal. Ao se compararem as concentrações obtidas para todos os elementos inorgânicos das amostras dos diferentes lodos com os limites de concentração estabelecidos pela Resolução 03/2006 do CONAMDF e pela Resolução 375/2006 do CONAMA, verifica-se que todas as concentrações são consideravelmente inferiores aos respectivos limites.

Como aspecto positivo em relação à composição do lodo dessas estações, é possível destacar o conteúdo de matéria orgânica, que, segundo diversos autores, pode melhorar a resistência dos solos à erosão e ao adensamento, ativando a vida microbiana dos solos e aumentando a resistência das plantas, pragas e doenças (Andreoli et. al., 1999; Bento, 2009).

Além disso, a eficiência agronômica do lodo de esgoto no suprimento de nutrientes às plantas ficou evidenciada nos resultados de pesquisas realizadas com lodos de esgotos das ETEs do DF, mostrando, inclusive, produtividades médias dos cultivos estatisticamente 
superiores às obtidas com o fertilizante mineral (Lemainski e Silva, 2006). Os estudos de Silva (2002) verificaram também o efeito residual da aplicação de lodo de esgotos em culturas do milho, nos quais se mostrou que ocorreu a manutenção da produtividade por até três anos agrícolas, mesmo na dose mais baixa testada (54 ton.ha $\left.{ }^{-1}\right)$.

\subsubsection{Cenário atual do manejo de lodo desaguado das ETEs do Distrito Federal}

As principais atividades de gerenciamento do lodo de esgoto no Distrito Federal são executadas de forma a atender as exigências legais de duas normas específicas: Resolução $n^{\text {o } 375 / 2006}$, do Conselho Nacional de Meio Ambiente - CONAMA; e a Resolução no 03/2006, do Conselho de Meio Ambiente do Distrito Federal - CONAM/DF. Ambas estabelecem os limites máximos admissíveis de concentração de metais pesados, a classificação dos tipos de lodo conforme a concentração de patógenos, as possibilidades de utilização de cada classe, além das necessidades de monitoramento da qualidade do lodo.

O manejo do lodo, atualmente, é realizado, priorizando, à medida do possível, a aplicação ao solo para recuperação de áreas degradadas. Para tanto, a CAESB busca disponibilização de áreas devidamente licenciadas para a disposição final. Como nem sempre existem áreas em condições viáveis de licenciamento para essa aplicação, o manejo desse lodo possui apenas outras duas vias: o armazenamento intermediário em estruturas das próprias ETEs ou a secagem natural implantada na área do complexo Samambaia/Melchior (Figura 5.23).

Conforme observado na Figura 5.23, ao longo dos anos, as alternativas de disposição final do lodo, adotadas no Distrito Federal, não seguiram uma tendência clara. Isso pode ser explicado pela dificuldade em se obter licenciamento ambiental para a uso do lodo na recuperação de áreas degradadas; essa dificuldade residiu, em sua maior parte, na inexistência de áreas regularizadas junto aos órgãos ambientais. Dessa forma, as outras alternativas de disposição identificadas - secagem natural ou armazenamento temporário eram adotadas conforme a conveniência operacional. 


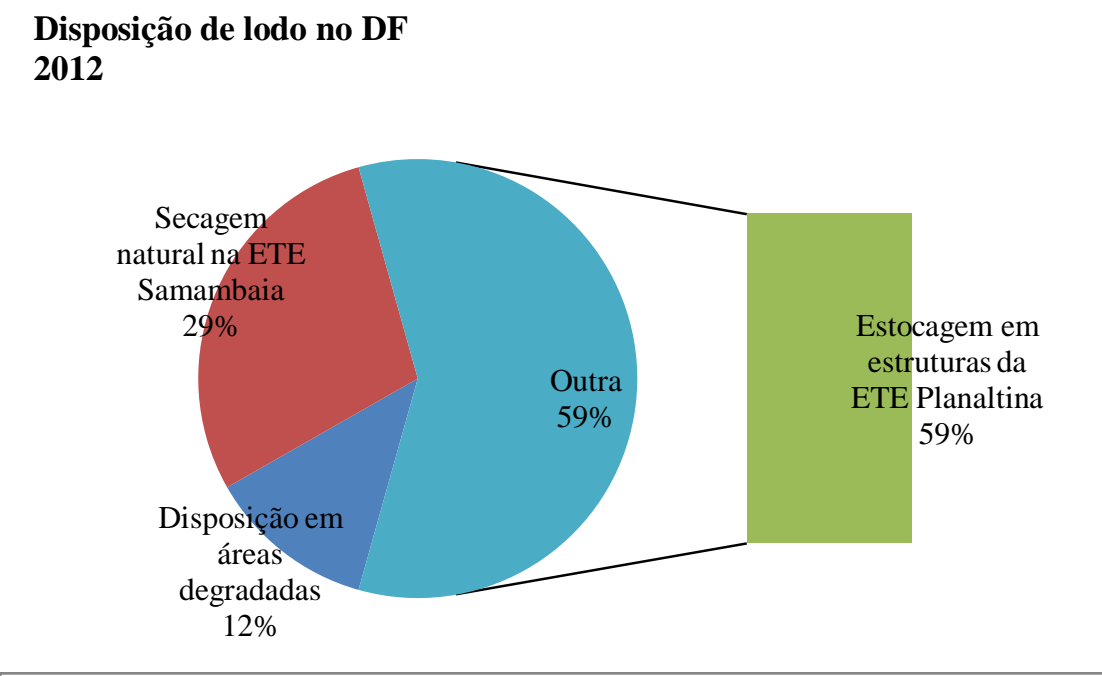

\section{Disposição de lodo no DF}

2013

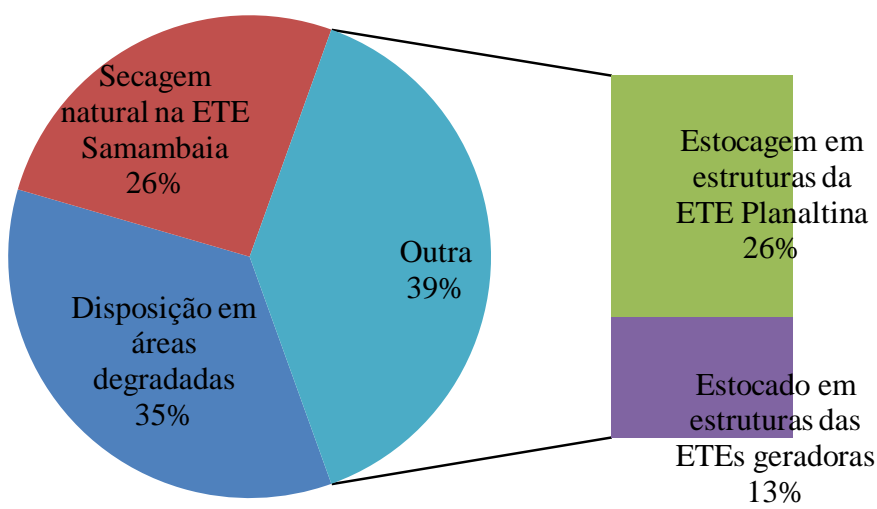

Disposição de lodo no DF

2014

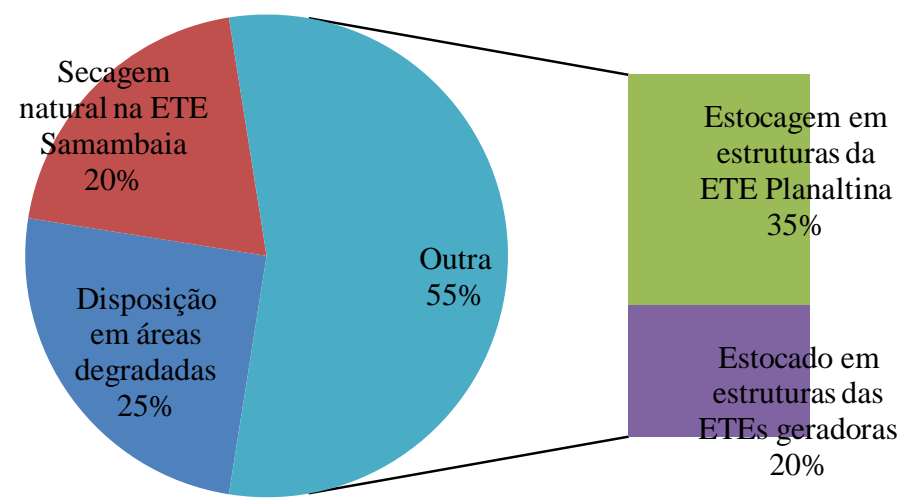

Figura 5.23- Evolução das Alternativas de disposição de lodo no DF (2012-2014) 
Segundo informações da CAESB (Relatório Administrativo, 2013), o gerenciamento de lodo no Distrito Federal concentra suas ações naquelas ETEs que geram lodos de esgoto diariamente, pois são responsáveis pelos elevados volumes de lodos produzidos no DF. As demais ETEs apresentam geração de lodos em quantidade significativamente menor e com frequência bastante irregular.

A gestão de lodos no Distrito Federal é diretamente influenciada pelas condições climáticas da região, que apresenta duas estações bem definidas:

a. estação chuvosa - compreendida entre os meses de outubro a abril; e

b. estação seca - que é considerada entre os meses de maio a setembro.

Durante a estação chuvosa, duas operações podem ocorrer separada ou concomitantemente: o armazenamento de lodo úmido em unidades da própria CAESB, com a finalidade de acondicionar de maneira segura os lodos gerados diariamente pelas ETEs, e a disposição para recuperação das áreas degradadas, essa última, contudo, depende da existência de áreas licenciadas e das condições locais de acesso e incorporação do lodo ao solo.

Em algumas estações de tratamento de esgotos, devido principalmente à sua proximidade com a comunidade e à inexistência de áreas e estruturas para manejo de grandes volumes de lodos - ETE Brasília Sul, Riacho Fundo, Brasília Norte e Sobradinho - o lodo produzido é transportado, por meio de caminhões basculantes, e armazenado em estruturas da ETE Planaltina, construídas originalmente, para comportar o descarte de fundo das lagoas de tratamento.

Nas demais ETEs os lodos gerados permanecem acumulados nas unidades geradoras ou são estocados em locais adaptados para acondicionar os lodos, com segurança, durante a estação chuvosa.

$\mathrm{Na}$ estação seca, tanto o lodo úmido que continua a ser gerado pelas ETEs, quanto o lodo úmido armazenado durante a estação chuvosa, são submetidos a um processo de secagem natural e irradiação solar que é realizado em baias adaptadas, localizadas na ETE Samambaia/ETE Melchior. O lodo é disposto em leiras de secagem e espalhado mecanicamente, o tempo médio de exposição ao sol é de 30 dias, após o que é recolhido e armazenado em pátios da unidade. 
Internamente, o gerenciamento adotado pela CAESB diferencia os lodos em lodo úmido, oriundo da etapa de desaguamento mecânico, e lodo processado, que se refere ao lodo submetido à secagem natural que ocorre no complexo Samambaia/Melchior, mencionado anteriormente. De acordo com informações obtidas junto aos agentes da companhia que gerenciam o manejo do lodo, entre as vantagens obtidas a partir dessa estratégia de manejo estão a redução do teor de água, do volume a ser armazenado e da concentração de patógenos no produto final.

Sempre que possível, ou seja, que haja áreas autorizadas para disposição do lodo e as características do mesmo atendam aos requisitos legais, é priorizada a expedição do lodo diretamente da ETE geradora, isto porque tanto o transporte do lodo para as áreas de armazenamento intermediárias e depois dessas para a secagem e destino final, quanto o processamento do lodo, propriamente dito, são operações onerosas. Segundo informações da CAESB o custo médio de manejo de lodo desaguado que é retirado das ETEs é de aproximadamente $\mathrm{R} \$ 10,00 / \mathrm{m}^{3}$; esses custos se referem ao transporte das unidades geradoras até o destino e o manejo de máquinas pesadas, seja para incorporação no solo, no caso da disposição em áreas degradadas, ou para o processamento do lodo, no caso da solarização.

A implantação da UGL - Unidade de Gerenciamento de Lodo, outra exigência prevista na legislação específica para a liberação da aplicação do lodo na agricultura, já está em andamento na Companhia de Saneamento Ambiental do Distrito Federal.

\subsection{AVALIAÇÃO DO DESEMPENHO DAS UNIDADES DE TRATAMENTO DA FASE SÓlIDA E DO COMPORTAMENTO DO LODO AO LONGO DAS ETAPAS DE GERAÇÃO - ESTUdO DE CASO ETE BRASÍLIA NORTE}

O conhecimento do comportamento do lodo ao longo das etapas de tratamento de uma ETE, bem como dos parâmetros que podem influenciar os processos de geração do lodo, quer seja qualitativa ou quantitativamente, tem relevante importância à medida que pode balizar o planejamento de ações para a gestão adequada do lodo ainda na concepção das alternativas e orientar a adoção de rotinas operacionais que visem à melhoria de desempenho nos processos que dão origem ao lodo. 
A ETE Brasília Norte reúne as características necessárias ao estudo dessas variáveis, uma vez que, conforme mencionado anteriormente, apresenta:

- condições operacionais estáveis;

- estruturas e instalações preservadas;

- controle operacional sistematizado; e

- garante representatividade da variabilidade de lodos gerados.

\subsubsection{Detalhamento do fluxo de tratamento da fase sólida da ETEB Norte}

O fluxograma de tratamento de esgotos da ETEB Norte é bastante complexo e foi comentado brevemente na metodologia (4.3.1). Nesse tópico será abordado de maneira mais aprofundada o fluxo de tratamento do lodo (fase sólida), com uma descrição das unidades e das linhas de fluxo principal e alternativo, de forma a detalhar os processos e possibilitar o delineamento do problema, facilitando a sua compreensão.

A Figura 5.24 apresenta o fluxograma da ETE Brasília Norte, em que foram destacadas as unidades de tratamento da fase sólida e seus respectivos caminhos ao longo da estação e a Tabela, 5.16 apresenta a descrição das unidades de tratamento da fase sólida da ETEB Norte.

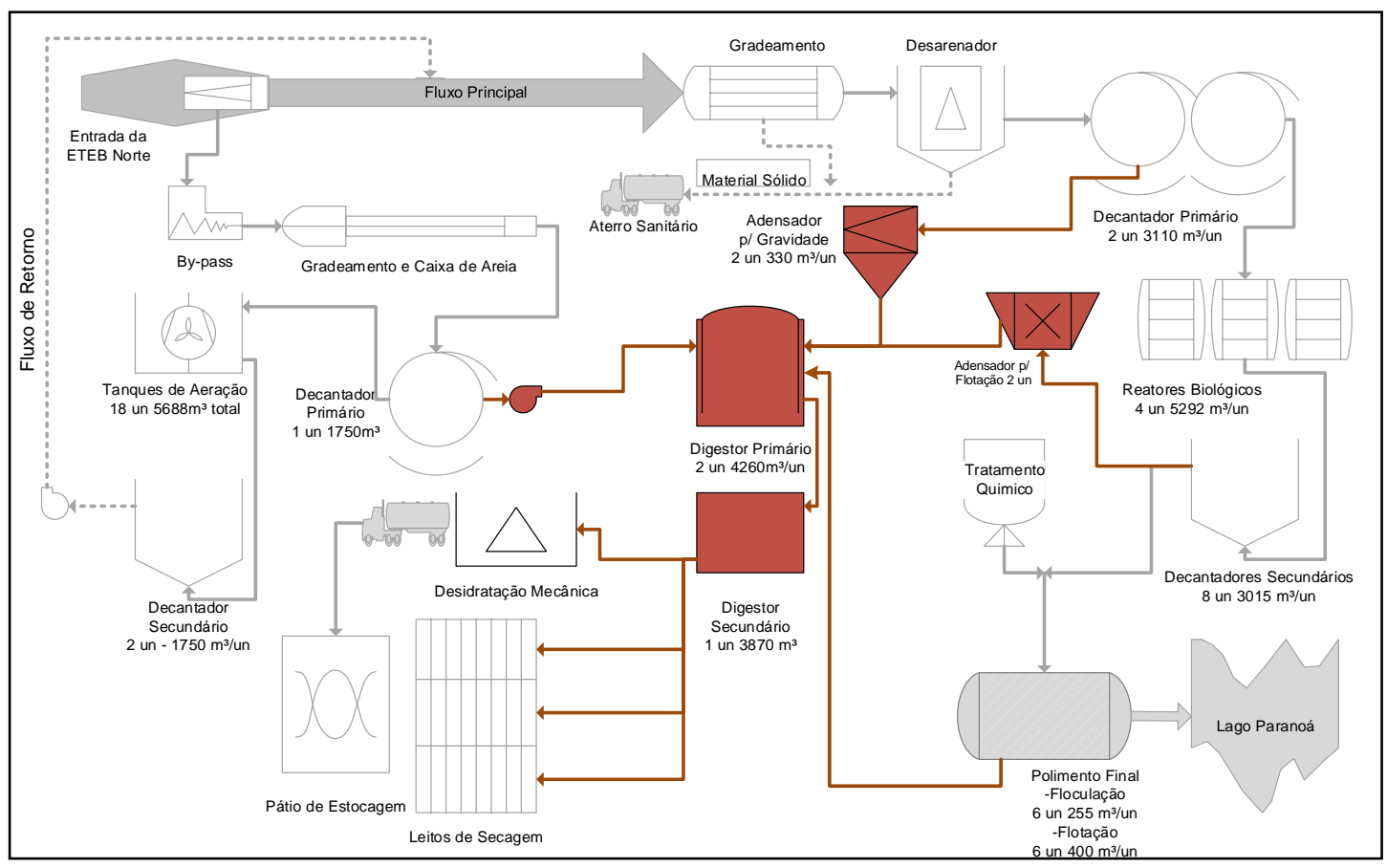

Figura 5.24 - Fluxograma da ETE Brasília Norte - Tratamento da fase sólida Adaptado de Nakazato (2005) 
Tabela 5.16 - Descrição das unidades de tratamento da fase sólida da ETEB Norte

\begin{tabular}{l|c|c|c}
\hline \multicolumn{1}{c|}{ Unidade } & $\begin{array}{c}\mathbf{N}^{\mathbf{0}} \text { unidades/ } \\
\text { unidades em } \\
\text { operação }\end{array}$ & $\begin{array}{c}\text { Dimensões: } \\
\mathrm{D} \times \mathrm{P}\end{array}$ & $\begin{array}{c}\text { Volume } \\
\mathrm{m}^{3}\end{array}$ \\
\hline $\begin{array}{l}\text { Decantador } \\
\text { Primário }\end{array}$ & $2 / 1$ & $32 \times 3,5$ & 3.110 \\
\hline $\begin{array}{l}\text { Adensador por } \\
\text { gravidade }\end{array}$ & $2 / 1$ & $10 \times 4,0$ & 400 \\
\hline $\begin{array}{l}\text { Adensador por } \\
\text { Flotação }\end{array}$ & $2 / 2$ & $11 \times 4,0$ & 330 \\
\hline $\begin{array}{l}\text { Digestor Primário } \\
\text { Digestor }\end{array}$ & $2 / 2$ & $20 \times 12$ & 3.750 \\
\hline Secundário & $1 / 1$ & $22 \times 10$ & 4.150 \\
\hline $\begin{array}{l}\text { Câmaras de } \\
\text { Flotação }\end{array}$ & $\begin{array}{c}6 / \\
\text { condicionado a } \\
\text { vazão }\end{array}$ & $\begin{array}{c}12,5 \times 8 \times 4 \\
(\text { CxLxP) }\end{array}$ & 400 \\
\hline
\end{tabular}

\subsubsection{Decantador Primário}

Os esgotos oriundos do tratamento preliminar são distribuídos para o decantador primário. Os decantadores da ETEB Norte são tanques circulares, de fundo cônico, cujas dimensões são descritas na Tabela 5.16, providos de pontes raspadoras que direcionam o os sólidos sedimentados para o centro, de onde são removidos. A estação possui duas unidades, entretanto, atualmente, opera com apenas um decantador.

O processo de decantação é dinâmico, onde a separação das fases líquida-sólida ocorre e forma contínua. A remoção do lodo primário é mecanizada e a definição dos ciclos (tempo de intervalo e tempo de remoção) ocorre pela observação empírica do funcionamento do decantador, ao longo do tempo de operação da ETE. A retirada do lodo ocorre periodicamente por meio de válvulas motorizadas, uma em cada decantador, que são acionadas por temporizadores, o lodo é direcionado para o adensador por gravidade (ADG), sem a necessidade de bombeamento. Na superfície há um coletor de escuma que recebe o material flotado, direcionando-o para o poço de lodo de fundo e seguindo dali para o ADG. 


\subsubsection{Adensador por gravidade}

A estação possui dois adensadores por gravidade, mas, normalmente, opera com apenas uma unidade. São unidades de formato cilíndrico, com dimensões descritas na Tabela 5.16.

Os adensadores recebem o lodo e a escuma provenientes do decantador primário, onde o lodo permanece por várias horas e é concentrado no fundo, pelo princípio de sedimentação por zona. A escuma que flota na superfície é raspada para uma caixa denominada caixa coletora de escuma e, posteriormente encaminhada para o digestor em conjunto com o lodo adensado.

O descarte de lodo adensado é realizado manualmente, segundo rotina operacional da unidade, e seu controle é realizado pelo volume descartado, por meio de medidor eletromagnético instalado na linha de descarte de lodo. A definição do volume e do intervalo de descarte fundamenta-se na avaliação dos resultados do adensamento e das condições operacionais da etapa subsequente (digestor anaeróbio de lodo). Por vezes, um descarte pode ser interrompido ou prolongado, caso o operador verifique, pelo aspecto visual, que a concentração do lodo está fora das condições típicas. O lodo descartado do adensador alimenta o poço de lodo adensado e é bombeado para os digestores anaeróbios, enquanto o sobrenadante retorna ao tratamento da fase líquida no canal afluente aos reatores biológicos.

\subsubsection{Adensador por flotação}

O adensamento por flotação ocorre por meio da injeção de ar na massa líquida. As bolhas de ar aderem às partículas sólidas diminuindo sua densidade, de maneira a promover o arraste ou flutuação dessas partículas até a superfície da massa líquida.

A operação da unidade de adensamento de lodo por flotação (ADF) inicia-se com o bombeamento do lodo excedente, lodo aeróbio não estabilizado, originário do controle da idade de lodo nos reatores biológicos. O lodo, então, adentra a câmara de entrada dos flotadores, onde se mistura com água recirculada e saturada com ar, caracterizando a chamada dissolução indireta. Dentro da câmara de entrada, as microbolhas são liberadas pela despressurização da água e prendem-se aos flocos de lodo, fazendo-os subir até a superfície. 
Tanto a pressurização quanto a despressurização são pontos importantes para o bom funcionamento de um sistema de flotação.

O lodo flotado, com elevada concentração de sólidos, é recolhido pelos raspadores superficiais e segue para um poço de lodo (PLD1) de onde é bombeado para os digestores primários anaeróbios. Uma pequena parte do lodo decanta e é extraído periodicamente do fundo pela operação de válvulas mecanizadas acionadas por temporizadores; esse lodo se junto ao lodo flotado e segue também por gravidade para o poço de bombeamento (PLD1).

O efluente líquido, denominado sobrenadante, é transferido por gravidade aos tanques de regularização de vazão e de lá são retornados ao canal afluente da estação, logo antes das peneiras, nos horários de baixa vazão, operação definida pelo regime de vazão da estação.

Parte do sobrenadante vai para a câmara de equilíbrio, que comunica com a parte inferior, com a câmara de sucção das bombas (comunicação aberta através de válvulas flap). Da câmara de sucção, a água é então pressurizada (por uma ou duas das três bombas instaladas), para o balão de pressurização, também chamado balão de saturação.

A vazão na descarga de cada bomba em operação é controlada através de válvula moduladora. $\mathrm{O}$ ar para a dissolução é fornecido por dois compressores.

\subsubsection{Câmara de flotação do polimento final}

A unidade de polimento final na ETEB Norte tem por objetivo remover fósforo e matéria orgânica residual presentes no efluente do tratamento biológico, por meio do princípio de floculação / flotação, para o que são utilizados produtos químicos, sulfato de alumínio como coagulante e polieletrólito aniônico como floculante, dando origem ao chamado lodo químico.

O precipitado formado após a adição do sulfato de alumínio é introduzido nas câmaras de floculação, onde recebem a solução de polieletrólito aniônico, e o líquido floculado é encaminhado às câmaras de flotação. Nessas câmaras, a flotação ocorre pela dispersão de ar em grande quantidade, dissolvido na massa líquida, realizado por um sistema de saturação que utiliza ar proveniente de compressores e efluente final e que é controlado por um supervisório que comanda toda a unidade de polimento final. 
A mistura ar/água é distribuída na entrada de cada uma das seis câmaras de flotação por meio de difusores, onde a brusca diferença de pressão dá origem às microbolhas que impulsionam os flocos para a superfície da câmara, de onde são removidos por meio de raspadores (Figuras 5.25 e 5.26) que direcionam o lodo para os poços de lodo químico flotado, localizados nos dois extremos da unidade. Em seguida, esse lodo é encaminhado para os digestores primários por meio de bombeamento.

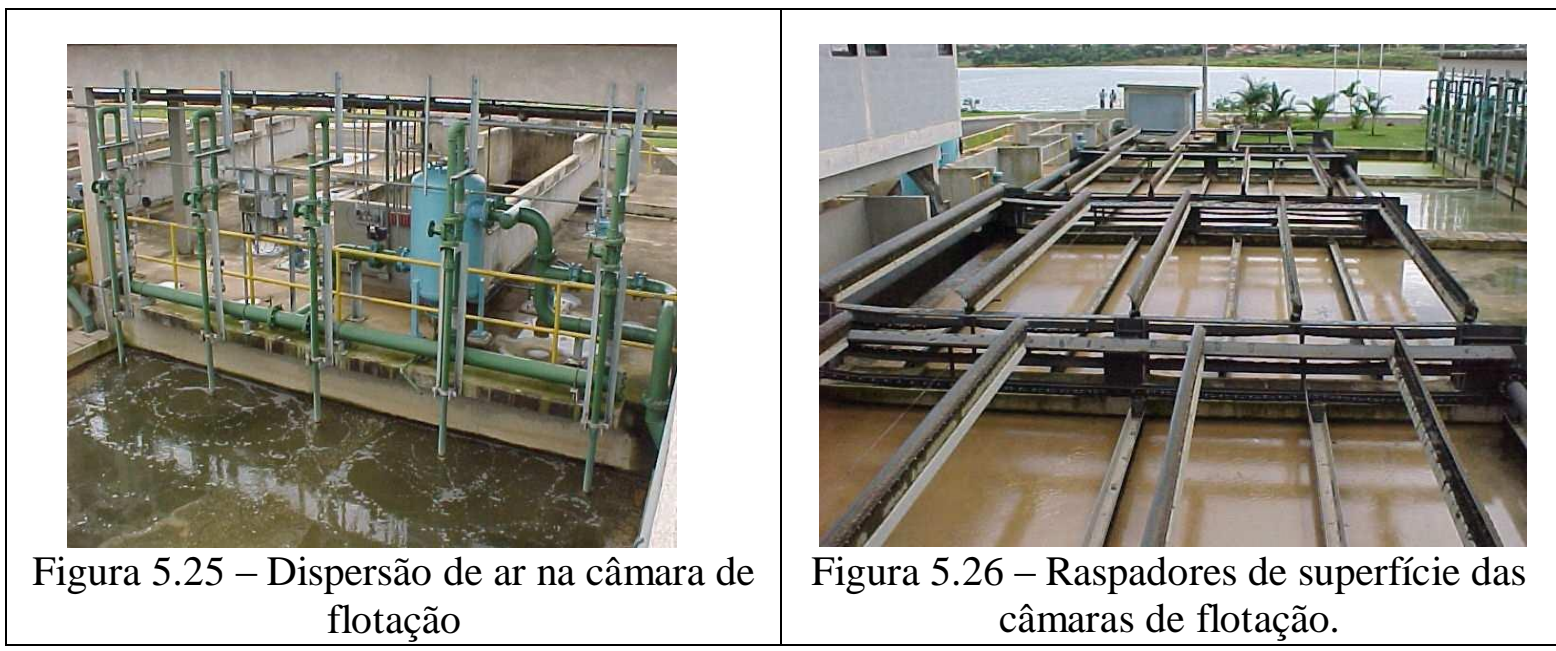

\subsubsection{Digestor primário anaeróbio}

O processo de digestão do lodo na ETEB Norte compreende dois digestores primários anaeróbios e um digestor secundário. Essas unidades datam do início de operação da primeira planta da estação, em 1969.

Os digestores primários recebem o lodo primário adensado, o lodo aeróbio (proveniente dos adensadores por flotação) e o lodo químico, oriundo da etapa de polimento químico da estação. A alimentação dos digestores é contínua, em se tratando do lodo aeróbio e lodo químico e em bateladas no caso do lodo primário. As redes de alimentação possuem registros que permitem a alternância da alimentação entre os digestores anaeróbios primários e o isolamento de um deles, caso necessário. Os digestores primários são dotados de sistema de recirculação interna que compreende três bombas de recirculação $(2 \mathrm{O}+1 \mathrm{R})$, rede de sucção, que faz a tomada de lodo no fundo dos digestores, e rede de recalque que retorna o lodo pela parte superior do digestor, por meio de tubulação perfurada ao longo de toda a circunferência junto à cúpula. O sistema possui ainda flexibilidade operacional que 
permite a recirculação de um digestor para outro, manobra que é utilizada quando se pretende inocular um dos digestores ou favorecer a equalização entre os mesmos.

Originalmente a operação dos digestores primários previa o fluxo de alimentação / descarte de lodo de forma intertravada, ou seja, a cada descarte de lodo para o digestor ocorreria a extravasão de lodo digerido do digestor primário para o digestor secundário. Entretanto, problemas com a impermeabilização da cúpula e do anel superior de ambos digestores, com risco de rompimentos, exigiram uma mudança no esquema de operação, que passou a definir o descarte do digestor primário para digestor secundário a partir da necessidade de volume útil para receber os lodos produzidos na estação. Dessa forma, atualmente, a denominada passagem de lodo, ocorre de maneira a propiciar o volume necessário ao próximo período de produção de lodos, que pode ser de $24 \mathrm{~h}$ ou menos, a depender das condições operacionais da estação.

No digestor secundário, o lodo é concentrado no fundo do mesmo, de onde segue para alimentar as bombas do sistema de desaguamento mecanizado de lodo ou, em casos específicos, para alimentar os leitos de secagem ainda em operação na estação.

A drenagem do líquido sobrenadante do digestor secundário foi uma operação prevista em projeto, mas ao longo do tempo tornou-se esporádica, visto que a entrada de lodo digerido, proveniente dos digestores primários, ocorre pelo fundo da unidade e não na altura intermediária, conforme recomendado na literatura clássica (Chernicharo, 2007), dificultando o adensamento desse lodo no fundo do digestor, pelo revolvimento provocado por ocasião da passagem do lodo.

Ainda, devido a uma intervenção de manutenção, a tubulação de remoção do lodo, que antes removia o lodo diretamente do fundo, foi seccionada e, atualmente, o lodo é retirado à mesma altura da alimentação. Por essa razão, a rotina de operação foi alterada para que a passagem de lodo ocorra, sempre que possível em horário contrário à operação da desidratação mecânica.

\subsubsection{Condicionamento e desaguamento de lodo}

O processo de desaguamento de lodo na ETEB Norte possui um fluxo principal que é o desaguamento mecânico e, como alternativa de contingência, utilizam-se os leitos de secagem, que são estruturas da instalação da ETE antiga. O condicionamento do lodo 
digerido ocorre concomitantemente com o processo de desaguamento, no fluxo principal, e é dispensada na ocorrência de disposição nos leitos.

Os equipamentos utilizados para a desidratação são prensas desaguadoras do tipo esteira. Atualmente estão em funcionamento duas prensas, a terceira foi retirada para que fossem iniciados os serviços de instalação da centrífuga.

O condicionamento do lodo ocorre com adição de polímero catiônico, cuja solução é preparada em processador automático, com uma concentração de $0,29 \%$.

O lodo digerido proveniente do digestor secundário chega à unidade de desaguamento no poço de lodo digerido (PLD-2), dali o lodo é bombeado para os floculadores acoplados às prensas, enquanto a solução de polímero é bombeada para a rede de recalque dessas bombas. O lodo, já floculado, penetra na zona de deságue natural, em seguida, na zona de prensagem, ocorre a desidratação final à medida que a massa de lodo passa por entre duas telas filtrantes, promovendo assim a retirada da água ali contida.

O lodo prensado, denominado de torta, é encaminhado por meio de correia transportadora para caminhões do tipo basculante e, posteriormente, transportado para as áreas de armazenamento intermediário ou de destinação final, conforme o caso.

O líquido drenado ou filtrado nessa operação, em conjunto com a água de lavagem das telas e o líquido drenado proveniente dos leitos de secagem, são encaminhados para um tanque de mistura (TMC-01). Para o condicionamento do efluente líquido da desidratação, é adicionada suspensão de hidróxido de cálcio hidratada (cal), que se combina com o fósforo existente no filtrado, formando fosfato de cálcio.

O filtrado condicionado segue do tanque de mistura para a canaleta de alimentação do decantador adensador (DAD), onde ocorre a separação do fosfato de cálcio que precipita no fundo do tanque junto com os sólidos remanescentes. A remoção do lodo do fundo do DAD processa-se com o auxílio de um raspador de fundo diametral; o lodo removido é descartado e estocado no poço de lodo lateral, sendo bombeado para o PLD2, para ser desidratado juntamente com o lodo digerido.

O sobrenadante do DAD é enviado ao canal afluente à estação, em um ponto à montante das peneiras, juntamente com o sobrenadante do ADF, via bombeamento. 


\subsubsection{Avaliação do desempenho das unidades de tratamento da fase sólida e do comportamento do lodo ao longo do sistema.}

A compreensão do comportamento do lodo demanda uma avaliação das componentes que interferem nos processos de geração, afetando a qualidade e os volumes de lodos gerados no sistema.

Foram avaliados, nesse estudo, aqueles parâmetros que expressam a qualidade do lodo, o desempenho das unidades de tratamento, além das variáveis operacionais que podem impactar a eficiência dos tratamentos ao longo das diferentes fases de geração de lodo na ETE (Tabela 4.1). Os dados disponibilizados para a realização do diagnóstico compreenderam os anos de 2008 a 2014, sendo o último marcado pelo acompanhamento da rotina operacional, no qual, para determinadas unidades, foi proposta alteração de parâmetros para a avaliação do comportamento do lodo.

\subsubsection{Decantador primário}

A decantação primária tem por objetivo remover parte da matéria orgânica afluente à estação, condicionando os esgotos para a próxima etapa do tratamento da fase líquida. Sua importância no que tange ao tratamento da fase sólida se refere à produção de lodo primário.

A concentração de sólidos no lodo primário da ETEB Norte é apresentada nas Figuras 5.27 e 5.28 e Tabela 5.17 que traz a série temporal de concentrações de sólidos totais, em um período de 7 anos de operação, dados disponibilizados para o presente estudo. 


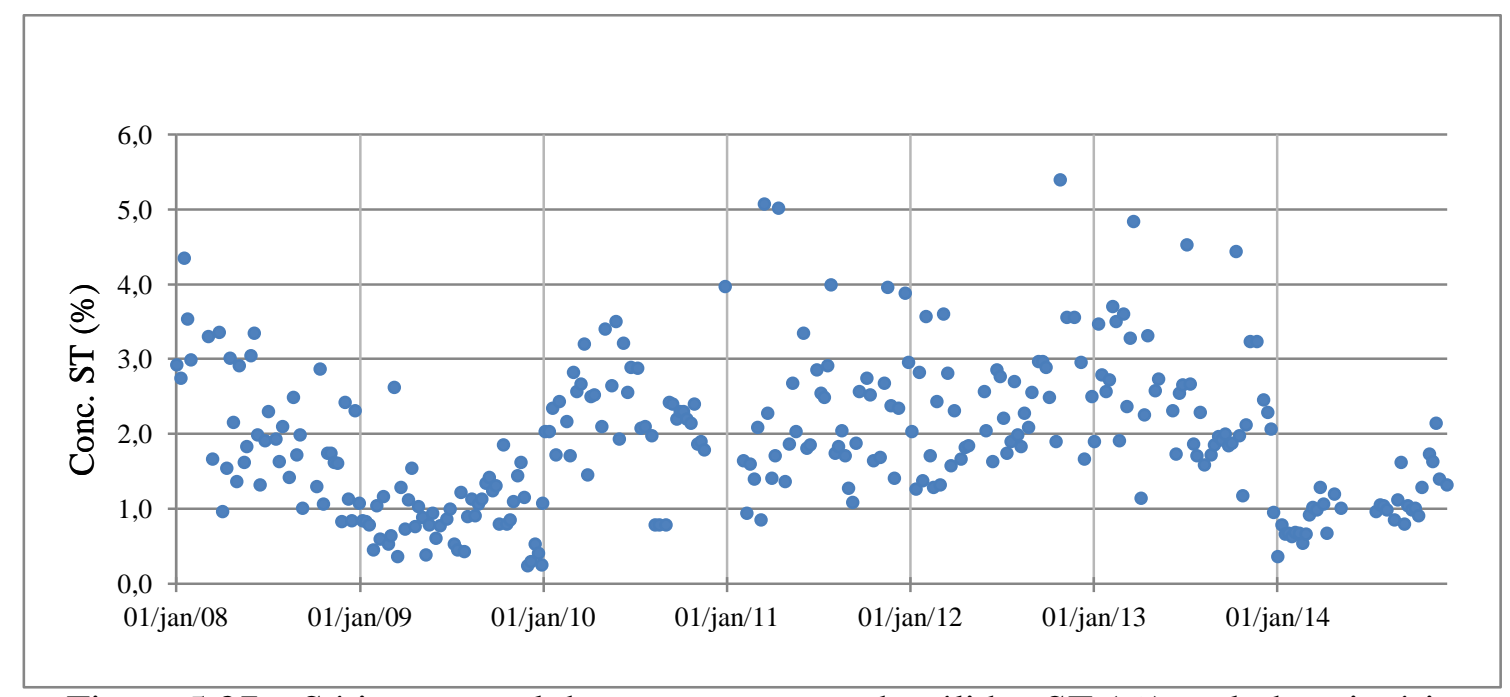

Figura 5.27 - Série temporal das concentrações de sólidos ST (\%) no lodo primário

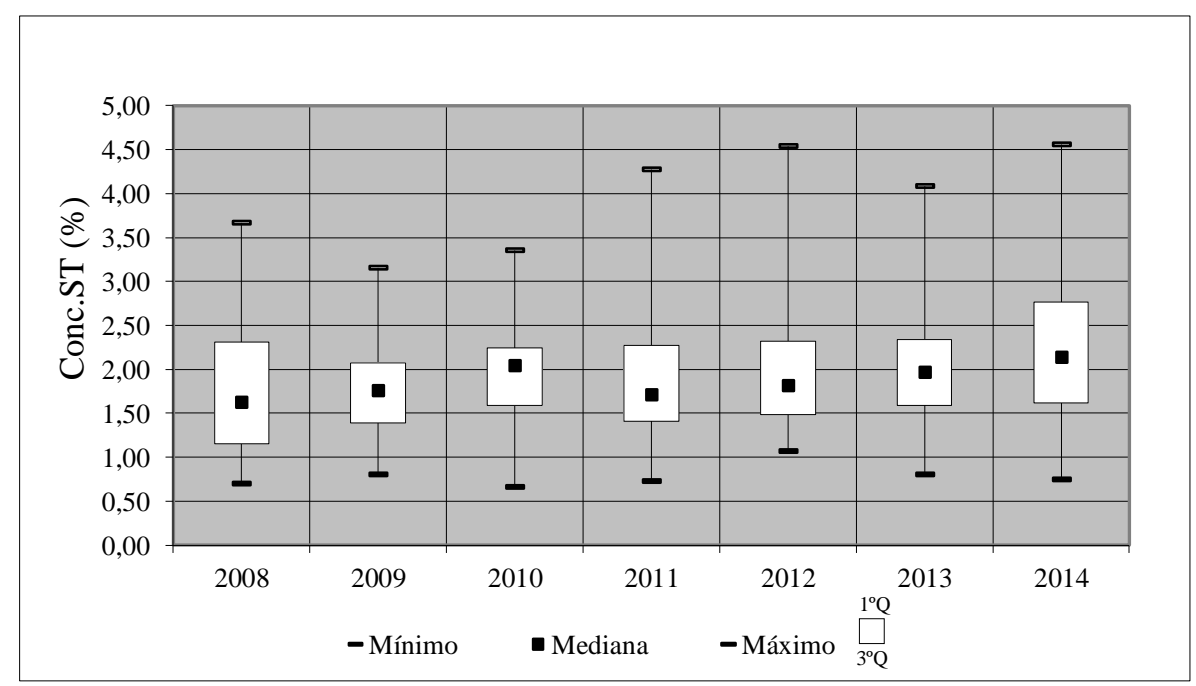

Figura 5.28 - Concentração de sólidos ST (\%) no decantador primário - valores mínimos, máximos, mediana e os $1^{\circ}$ e $3^{\circ}$ quartis.

Tabela 5.17 - Estatística descritivas dos teores de ST(\%) no lodo primário na ETEB Norte

\begin{tabular}{ccccccc}
\hline Ano & $\mathbf{1}^{\mathbf{0}} \mathbf{Q}$ & Mínimo & Mediana & Média & Máximo & $\mathbf{3}^{\mathbf{0}} \mathbf{Q}$ \\
\hline \hline 2008 & 1,48 & 0,83 & 1,92 & 2,07 & 4,35 & 2,81 \\
\hline 2009 & 0,61 & 0,24 & 0,89 & 0,93 & 2,62 & 1,15 \\
\hline 2010 & 1,98 & 0,79 & 2,30 & 2,29 & 3,98 & 2,56 \\
\hline 2011 & 1,66 & 0,86 & 2,04 & 2,29 & 5,08 & 2,68 \\
\hline 2012 & 1,83 & 1,27 & 2,28 & 2,38 & 5,40 & 2,83 \\
\hline 2013 & 1,90 & 0,95 & 2,30 & 2,49 & 4,85 & 2,90 \\
\hline 2014 & 0,74 & 0,37 & 0,99 & 1,02 & 2,15 & 1,16 \\
\hline
\end{tabular}

Observa-se, pela análise dos dados, que as concentrações médias de ST no lodo primário da ETEB Norte, ao longo do tempo, não tiveram variações significativas, com exceção dos anos 2009 e 2014, que apresentaram teores de sólidos de 0,93 e 1,02\%, respectivamente. 
Nos anos de 2008 e 2010 a 2013, as concentrações médias estiveram entre 2,29 a 2,49\%, esses resultados demonstram uma operação satisfatória dessa unidade, visto que, segundo Andreoli et. al. (2001), as concentrações esperadas no lodo primário estão entre 2 a $6 \%$.

No caso de 2009, pelo histórico operacional da estação, não há registros que indiquem uma causa provável para as menores concentrações encontradas.

Nas Tabelas 5.18 e 5.19 são apresentados os parâmetros de projeto e os dados operacionais do decantador primário da ETEB Norte, entre os anos de 2008 e 2014.

Tabela 5.18 - Parâmetros de projeto do decantador primário da ETEB Norte

\begin{tabular}{c|c|c|c}
\hline \multirow{2}{*}{ Parâmetros de projeto } & $\begin{array}{c}\text { Vazão } \\
\text { L.s }\end{array}$ & $\begin{array}{c}\text { Carga de SST afluente } \\
\text { Kg.d }\end{array}$ & $\begin{array}{c}\text { Carga de lodo primário }^{2} \\
\text { Kg.d }^{-1}\end{array}$ \\
\hline \hline Mínima & 550 & 9.504 & 5.702 \\
\hline Média & 920 & 15.742 & 9.445 \\
\hline Máxima & 2.300 & 39.744 & 23.846 \\
\hline
\end{tabular}

Notas: (1) Carga de sólidos calculada segundo concentração de SST estimada em projeto: 200mg.L ${ }^{-1}$

(2) Carga de lodo determinada de acordo com os parâmetros de projeto, com eficiência de projeto na decantação primária de $60 \%$, em que: Carga de lodo primário $=\mathrm{Q}_{\text {projeto }} * 86.400 * 60 \% * \mathrm{SST}$

Tabela 5.19- Dados operacionais do decantador primário da ETEB Norte

\begin{tabular}{|c|c|c|c|c|}
\hline Ano & 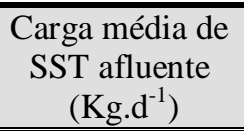 & $\begin{array}{l}\text { Carga média de lodo } \\
\text { primário - projeto }\end{array}$ & $\begin{array}{l}\text { Carga média de lodo } \\
\text { primário gerado } \\
\left(\mathrm{KgSST} . \mathrm{d}^{-1}\right)\end{array}$ & $\begin{array}{l}\text { Diferença entre } \\
\text { carga projetada e } \\
\text { gerada }(\%) \\
\end{array}$ \\
\hline 2008 & 8.904 & 25.342 & 6.837 & $\bar{c} \uparrow 28$ \\
\hline 2009 & 8.757 & 5.254 & 6.985 & 个33 \\
\hline 2010 & 7.044 & 4.226 & 7.956 & 个88 \\
\hline 2011 & 7.873 & 4.724 & 6.278 & 个33 \\
\hline 2012 & 9.137 & 5482 & 7.553 & 个38 \\
\hline 2013 & 9.659 & 5.795 & 9.533 & $\uparrow 65$ \\
\hline 2014 & 9.248 & 5.549 & 6.481 & $\uparrow 17$ \\
\hline
\end{tabular}

Nota: Carga média determinada considerando a carga de SST afluente à ETE e a remoção de sólidos esperada $(60 \%)$

Segundo o que pode ser observado, a carga de lodo primário gerado diariamente na ETEB Norte é bem superior ao estimado em projeto, uma possível justificativa para esse acréscimo pode ser o reciclo que ocorre de líquido sobrenadante das unidades de adensamento (adensador por flotação, adensador de lodo da desidratação) e do retorno da equalização de esgotos, que ocorre no ponto à montante das peneiras. Dessa forma, a carga afluente ao decantador primário é superior ao calculado a partir dos dados do afluente e depende das condições operacionais das unidades internas. Outra explicação estaria associada ao regime de extração de lodo do decantador primário, cuja definição é empírica. 
O monitoramento da rotina operacional realizado na estação, ao longo do ano de 2014, identificou que o descarte de lodo do decantador primário é um parâmetro que sofre poucas alterações no decorrer do tempo. As alterações, quando ocorrem, estão associadas principalmente a duas condições: intervenções de manutenção ou perdas de sólidos excessivas nos adensadores por gravidade.

Dessa forma, para identificação de possíveis melhorias com a alteração dos volumes extraídos do decantador, foram testados 3 ciclos distintos de descarte. Os resultados são mostrados na Tabela 5.20 e Figuras 5.29 e 5.30 a seguir.

Tabela 5.20 - Volumes médios de lodo descartado do decantador primário e concentrações médias de ST para cada ciclo.

\begin{tabular}{c|c|c|c|c|c}
\hline Ciclo & $\begin{array}{c}\text { Programação } \\
\text { Intervalo x descarte } \\
(\mathrm{min})\end{array}$ & $\begin{array}{c}\text { Período } \\
\text { monitorado }\end{array}$ & $\begin{array}{c}\text { Carga média } \\
\text { afluente ao DP } \\
(\mathrm{Kg} / \mathrm{d})\end{array}$ & $\begin{array}{c}\text { Volume médio de } \\
\text { lodo descartado } \\
\left(\mathrm{m}^{3} / \mathrm{d}\right)\end{array}$ & $\begin{array}{c}\text { Conc. } \\
\text { média } \\
\text { ST\% }\end{array}$ \\
\hline \hline $1^{1}$ & $15^{\prime} \times 3^{\prime}$ & $01 /$ jan -30/abr & 26.425 & 809 & 0,80 \\
\hline 2 & $25^{\prime} \times 3^{\prime}$ & $01 /$ ago $-30 /$ set & 30.463 & 731 & 1,06 \\
\hline 3 & $10^{\prime} \times 3^{\prime}$ & $01 /$ out $-30 /$ nov & 26.848 & 973 & 1,45 \\
\hline
\end{tabular}

Nota: 1 - O Ciclo 1 é o usual na ETEB Norte, historicamente adotado para o descarte de lodo primário.

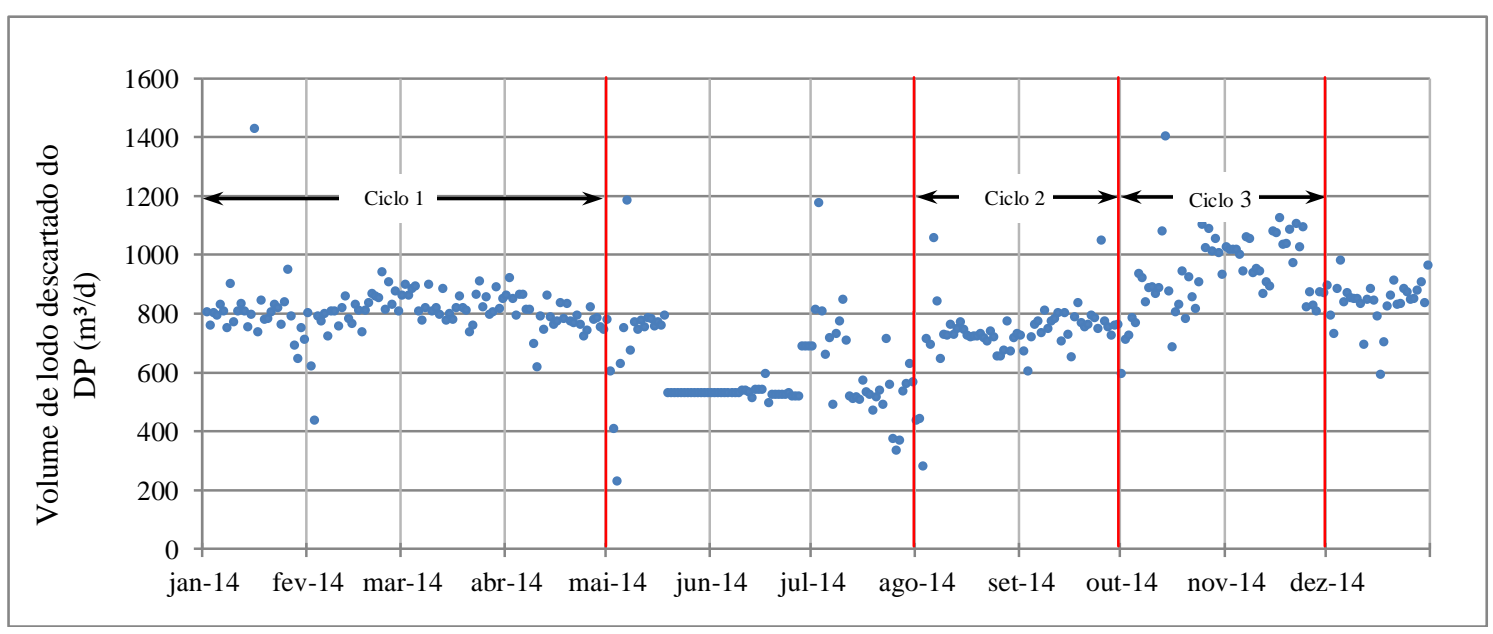

Figura 5.29 - Série temporal dos volumes de lodo descartado diariamente do Decantador Primário 


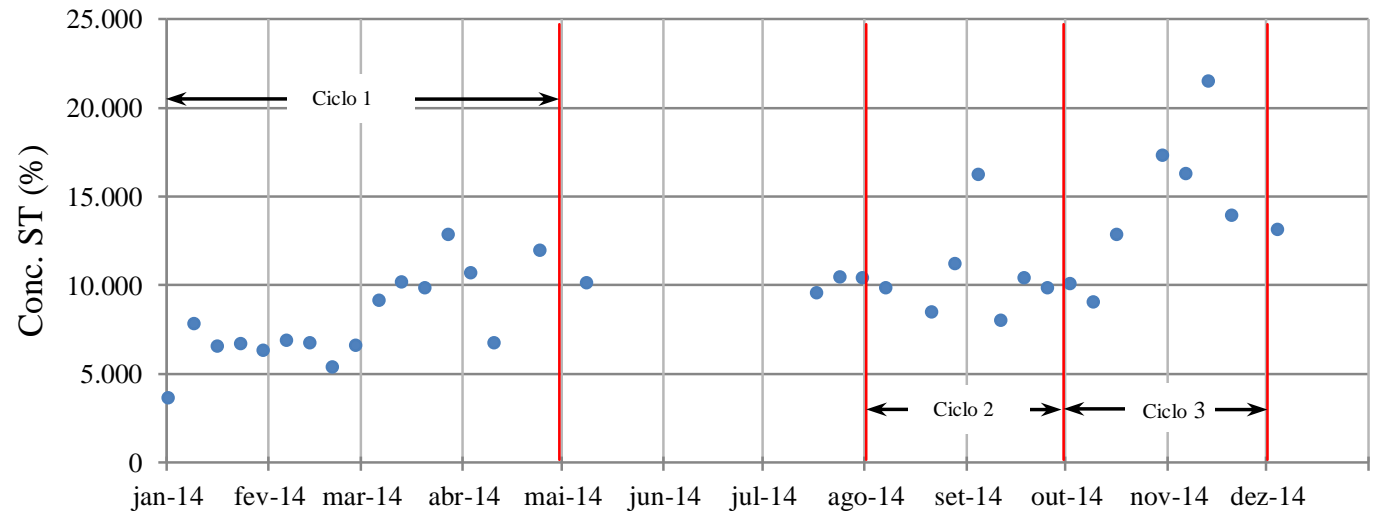

Figura 5.30 - Distribuição das concentrações do lodo primário, em termos de \%ST, ao longo dos 3 ciclos de extração de lodo testados

Os resultados mostraram que, para o primeiro e segundo ciclos, com volumes médios descartados diariamente de 809 e $731 \mathrm{~m}^{3}$, respectivamente, a variação da concentração média de sólidos verificada é de cerca de $25 \%$. Contrariamente ao esperado, para vazões de retirada do lodo de fundo mais elevadas, a concentração de sólidos foi superior em $75 \%$ em relação ao primeiro ciclo e em $32 \%$ em relação ao segundo ciclo. Entretanto, em todos os ciclos o teor de sólidos se manteve abaixo das concentrações indicadas pelos especialistas.

Como mencionado a princípio, a relevância do decantador primário para o tratamento da fase sólida reside no volume de lodo gerado, logo, a operação com intervalos de descarte maiores (ciclo 2) se mostrou mais eficiente que aquela, historicamente, adotada na operação do decantador primário, visto ter obtido um menor volume de lodo, com teor de sólidos $25 \%$ superior.

Os resultados do ciclo 3, apesar de apresentarem o melhor desempenho em termos de teor de sólidos, devem ser avaliados em conjunto com a unidade de adensamento do lodo, pois, como aponta Chao (2001), em seu estudo para otimização dos adensadores da ETE Barueri, a alimentação dos adensadores tem importância significativa na eficiência do adensamento por gravidade. 


\subsubsection{Adensador por gravidade}

O adensador por gravidade na ETEB Norte recebe apenas o lodo primário. Como a estação recebe uma vazão média de esgotos afluentes cerca de $44 \%$ inferior à vazão média de projeto, apenas um de seus adensadores está em operação.

Para a avaliação do comportamento do lodo nessa unidade, foram levantados os dados de concentração do lodo afluente (lodo primário), do lodo adensado e do sobrenadante que retorna ao processo, à montante dos reatores biológicos, além dos volumes respectivos. Os resultados são apresentados a seguir na Tabela 5.21 e Figuras 5.31 e 5.32.

Tabela 5.21 - Estatística descritiva dos teores de ST(\%) no lodo adensado (adensador por gravidade) na ETEB Norte

\begin{tabular}{ccccccc}
\hline Ano & $\mathbf{1}^{\mathbf{0}} \mathbf{Q}$ & Mínimo & Mediana & Média & Máximo & $\mathbf{3}^{\mathbf{0}} \mathbf{Q}$ \\
\hline \hline 2008 & 4,80 & 3,21 & 5,62 & 5,56 & 7,12 & 6,19 \\
\hline 2009 & 4,38 & 3,19 & 5,00 & 4,92 & 6,36 & 5,59 \\
\hline 2010 & 3,74 & 2,32 & 4,60 & 4,49 & 6,48 & 4,94 \\
\hline 2011 & 4,23 & 2,58 & 5,02 & 4,81 & 6,68 & 5,50 \\
\hline 2012 & 4,20 & 3,29 & 4,63 & 4,76 & 7,03 & 5,23 \\
\hline 2013 & 4,31 & 2,56 & 5,19 & 5,06 & 7,36 & 5,52 \\
\hline 2014 & 3,52 & 2,39 & 3,82 & 3,93 & 5,90 & 4,42 \\
\hline
\end{tabular}

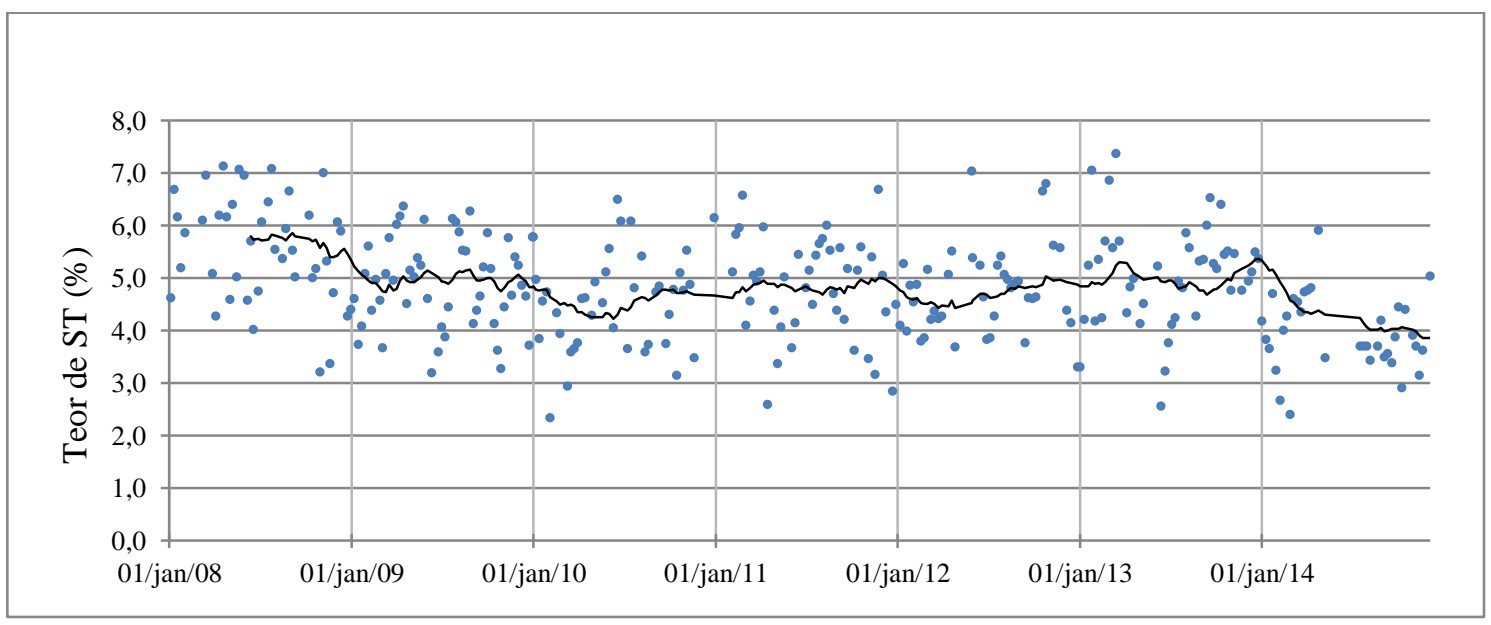

Figura 5.31 - Série temporal dos teores de sólidos totais no adensador por gravidade 


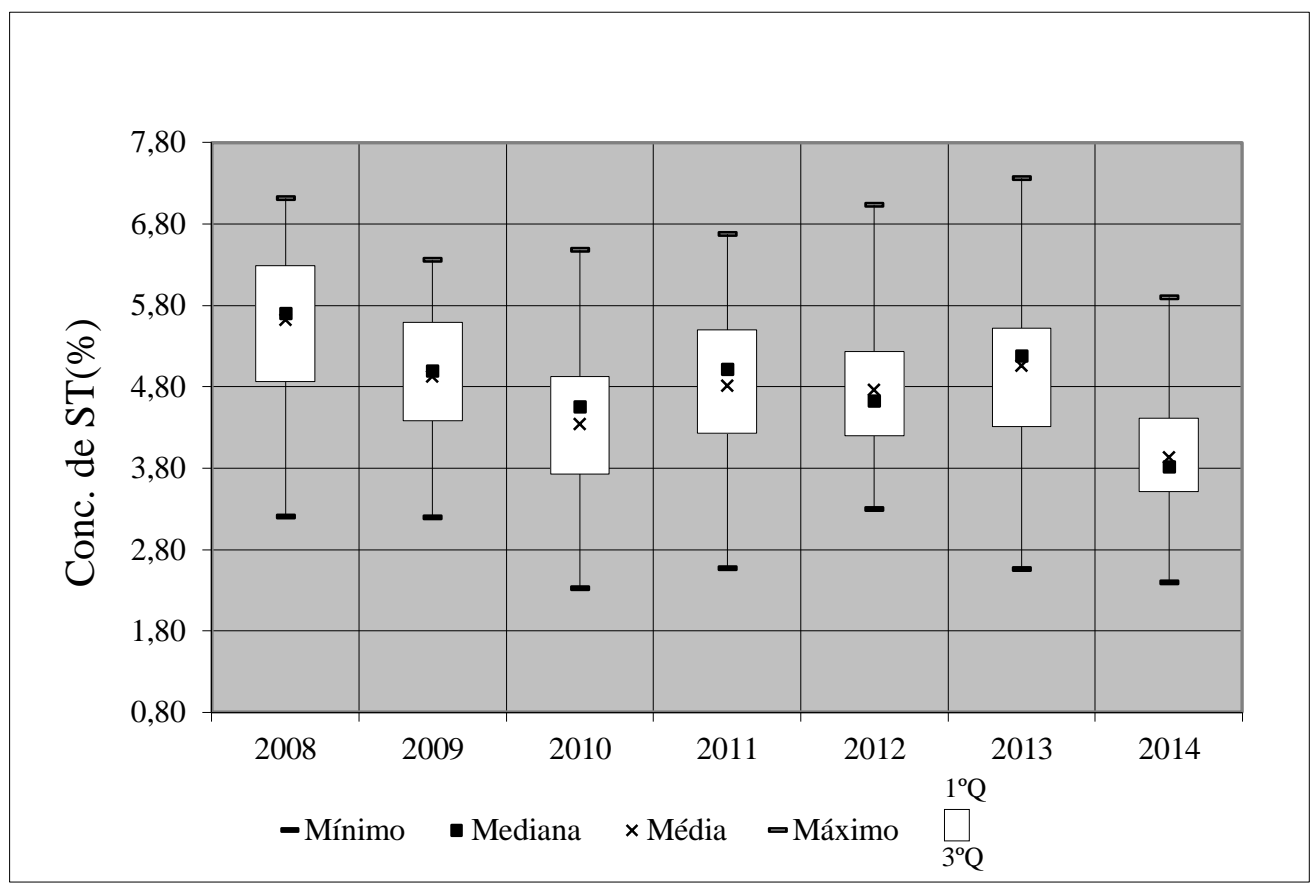

Figura 5.32 - Box-plot das concentrações de sólidos ST (\%) no lodo proveniente do adensador por gravidade

Os resultados mostram pequena variação entre as concentrações médias dos sólidos totais do adensador por gravidade, entre os anos 2008 e 2013, com resultados variando de 4,92 a $5,62 \%$, apresentando características típicas de lodo adensado, para caso de adensamento de lodo primário que, conforme a literatura clássica, deve variar entre 5 e 10\%. Em 2014, o lodo adensado acompanhou a tendência do lodo primário e apresentou os menores resultados em termos de concentração de ST $(3,93 \%)$.

Não obstante as concentrações médias não se distarem tanto, os dados apresentam uma variabilidade acentuada, mostrando uma dispersão elevada dos resultados. Os quartis apresentam resultados entre 3,52 e 6,19\%, com dados de máximo e mínimo entre 2,32 e $7,12 \%$. Isso pode apontar para uma instabilidade operacional da unidade que, por sua vez, pode impactar as condições operacionais da unidade subsequente, o digestor anaeróbio primário.

A finalidade principal de um adensador é concentrar o lodo afluente reduzindo o volume de lodo a ser tratado na fase subsequente, razão pela qual o teor de sólido deve ser monitorado. Entretanto, a captura de sólidos é outro importante parâmetro para avaliar o desempenho operacional da unidade, pois pode demonstrar quanto do lodo afluente ao adensador ficou retido no sistema. Para essa análise, foram levantados os seguintes dados, disponíveis nos formulários operacionais preenchidos diariamente: 
- Volume diário: lodo primário, lodo adensado e sobrendante;

- Concentração de sólidos totais: lodo primário, lodo adensado e sobrenadante;

A captura de sólidos no adensador por gravidade foi determinada a partir da equação apresentada na Tabela 4.4 .

Os resultados da captura de sólidos obtida no adensador por gravidade, ao longo dos anos de operação da ETEB Norte monitorados podem ser visualizados nas Figuras 5.33 e 5.34, a seguir.

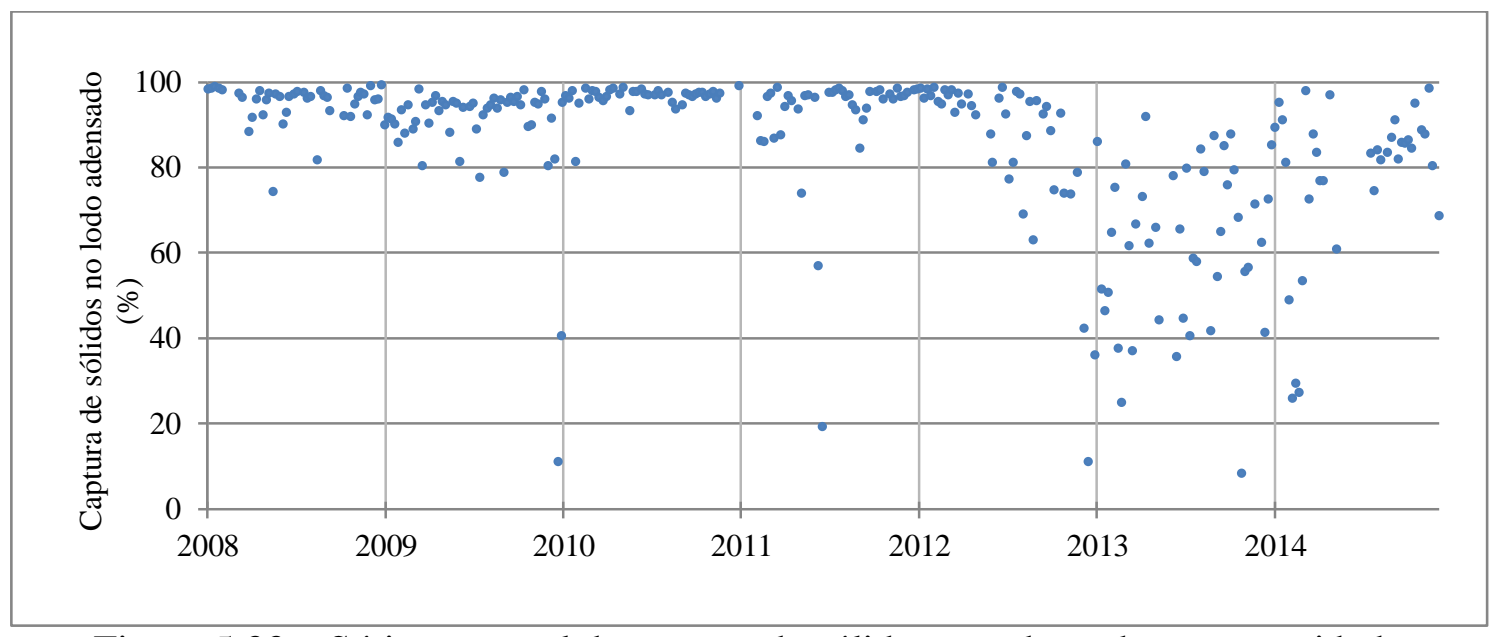

Figura 5.33 - Série temporal da captura de sólidos no adensador por gravidade

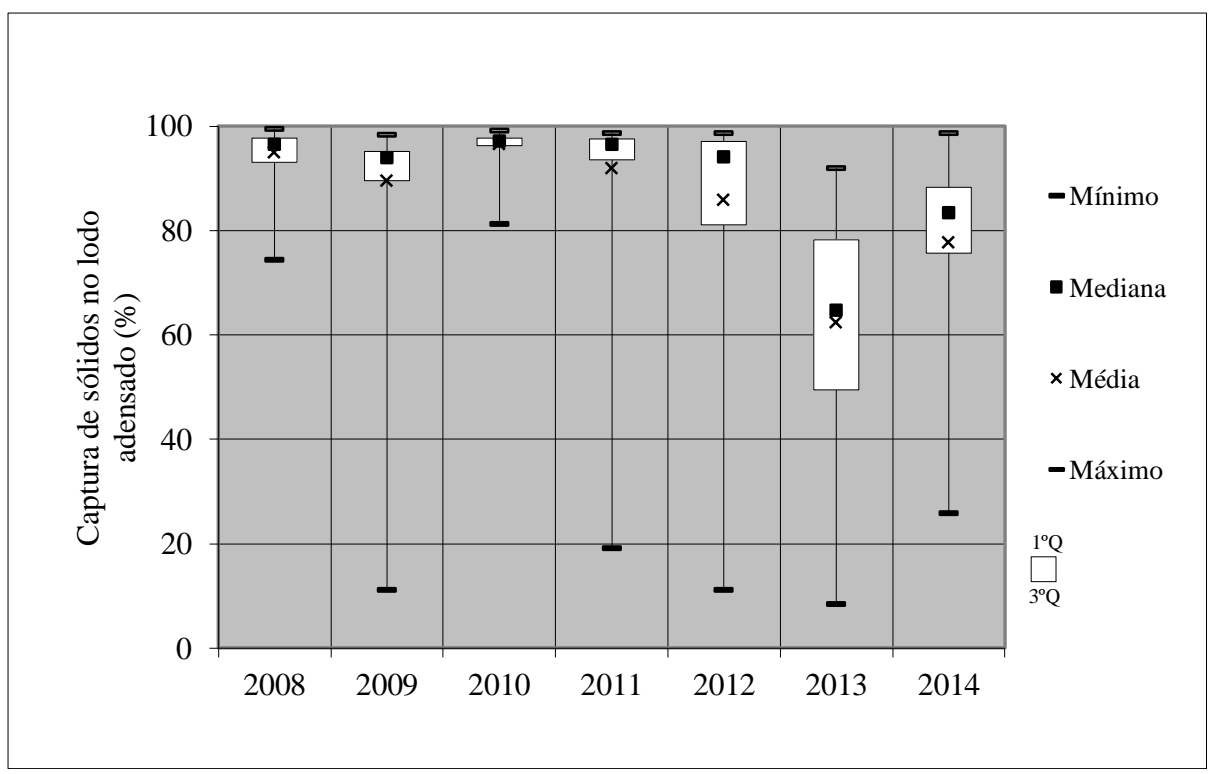

Figura 5.34 - Box-plot das capturas de sólidos ST (\%) no adensador por gravidade

Pela observação dos dados do adensador por gravidade na ETE Brasília Norte, podem ser visualizados dois períodos distintos no tocante à eficiência da captura de sólidos. No 
primeiro período, entre os anos 2008 e 2011, a unidade apresenta uma elevada eficiência, com valores superiores aos citados por Qasim (1985, apud von Sperling et. al., 2001) e ABNT (2011), que reportam eficiências variando de 85 a 92\% para adensador por gravidade adensando apenas lodo primário. Nesse período as eficiências médias variaram de 90 a $97 \%$.

No segundo período, anos 2012 a 2014, vê-se uma variabilidade crescente dos dados de eficiência, e uma queda acentuada da captura de sólidos, sugerindo uma instabilidade operacional nesta unidade.

Quando comparadas às cargas de lodo primário afluente, percebe-se que 2012 e 2013 foram marcados por um aumento de carga de lodo de cerca de 20 e $52 \%$, respectivamente, em relação ao ano anterior (Tabela 5.19). Os dados de projeto dos adensadores por gravidade previam uma carga afluente de lodo primário de $9.445 \mathrm{Kg} / \mathrm{d}$, logo, à exceção de 2014 (carga lodo primário: $8.340 \mathrm{Kg} / \mathrm{d}$ ), as cargas afluentes ao adensador estiveram sempre acima do estimado em projeto.

De maneira a subsidiar uma análise de correlação entre os parâmetros operacionais determinantes para o desempenho do adensador, foram levantadas as taxas de aplicação de sólidos (TAS) ao longo do tempo monitorado, que foi plotada no gráfico da captura de sólidos, os valores que podem ser visualizados na Figura 5.35 e Tabela 5.22.

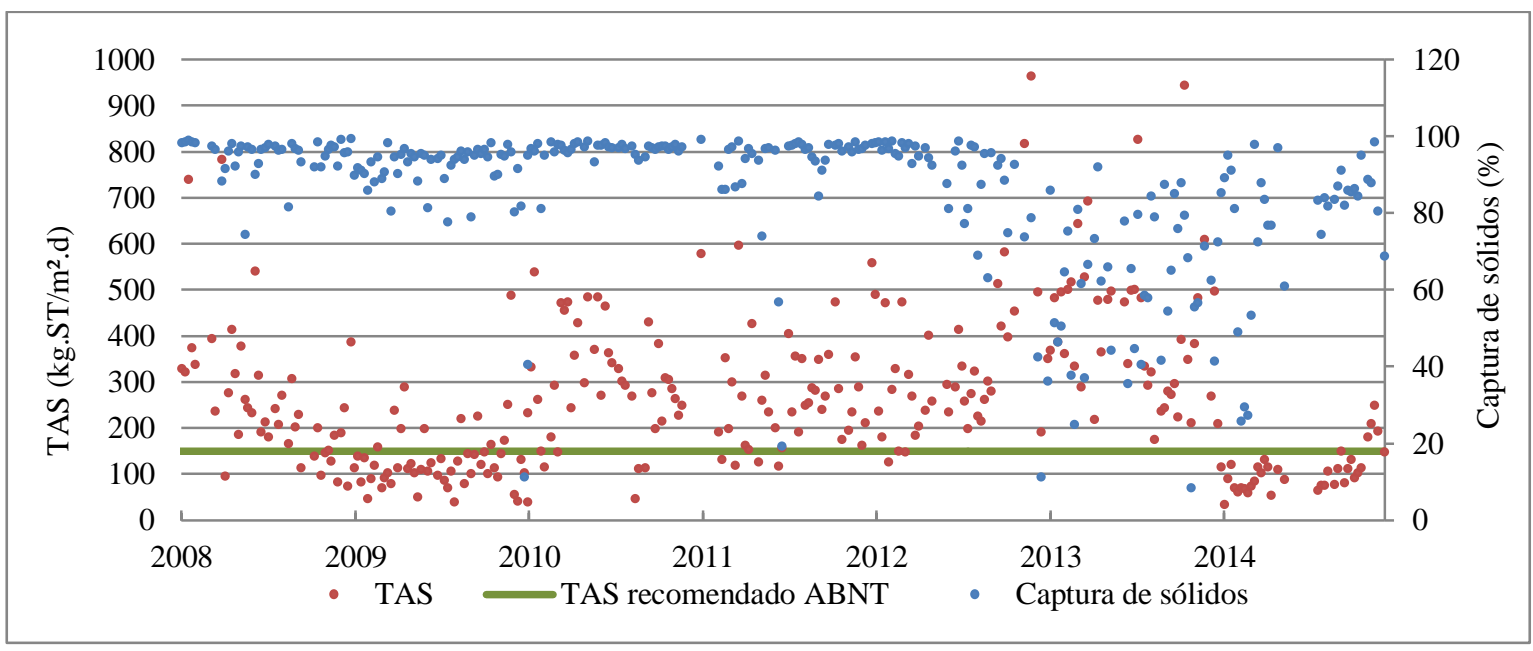

Figura 5.35 - Série temporal da taxa de aplicação de sólidos (TAS) e captura de sólidos no adensador por gravidade. 
Tabela 5.22 - Taxa de aplicação de ST (TAS - kgST/m².d) afluentes ao adensador por gravidade da ETEB Norte, entre os anos de 2008 e 2014

\begin{tabular}{ccccccc}
\hline Ano & $\mathbf{1}^{\mathbf{0}} \mathbf{Q}$ & Mínimo & Mediana & Média & Máximo & $\mathbf{3}^{\mathbf{0}} \mathbf{Q}$ \\
\hline 2008 & 173,15 & 72,92 & 233,10 & 261,21 & 783,61 & 320,15 \\
\hline 2009 & 90,84 & 38,79 & 114,03 & 133,18 & 488,93 & 146,87 \\
\hline 2010 & 243,32 & 46,77 & 298,34 & 310,01 & 579,03 & 382,47 \\
\hline 2011 & 192,49 & 116,41 & 257,12 & 275,42 & 596,39 & 349,56 \\
\hline 2012 & 232,57 & 126,88 & 286,81 & 334,20 & 963,70 & 403,77 \\
\hline 2013 & 286,35 & 115,40 & 375,81 & 406,69 & 943,43 & 496,61 \\
\hline 2014 & 74,47 & 34,39 & 102,18 & 106,19 & 248,97 & 117,91 \\
\hline
\end{tabular}

A ABNT (2011) cita que os valores para taxas de aplicação de sólidos (TAS) em adensadores por gravidade, recebendo lodo primário, devem estar abaixo de 150 $\mathrm{Kg} . \mathrm{ST} / \mathrm{m}^{2}$.d. As TAS obtidas no levantamento, mostram que o adensador por gravidade na ETE Brasília Norte vem operando com valores superiores ao recomendado, na maior parte do tempo, conforme pode ser observado na Tabela 5.22.

Pela figura 5.35, nota-se que entre os anos de 2008 e 2011, mesmo com TAS elevadas, superiores aos valores máximos recomendados, a eficiência na captura de sólidos esteve acima de $90 \%$. No ano de 2013, houve um aumento significativo da TAS, acompanhado por perda de eficiência na captura de sólidos, entretanto, o ano de 2014, com a menor taxa de aplicação de sólidos no período, não apresentou eficiência superior. O que corrobora a afirmação de Nunes e Além Sobrinho (2002) de que, apesar de relevante, o fator preponderante para o melhor desempenho do adensamento não é a concentração de sólidos no lodo afluente.

De maneira a ser avaliado o desempenho da captura de sólidos, mediante as alterações propostas para os ciclos de extração de lodo do decantador primário, o ano de 2014 foi considerado separadamente, conforme a Figura 5.36. 


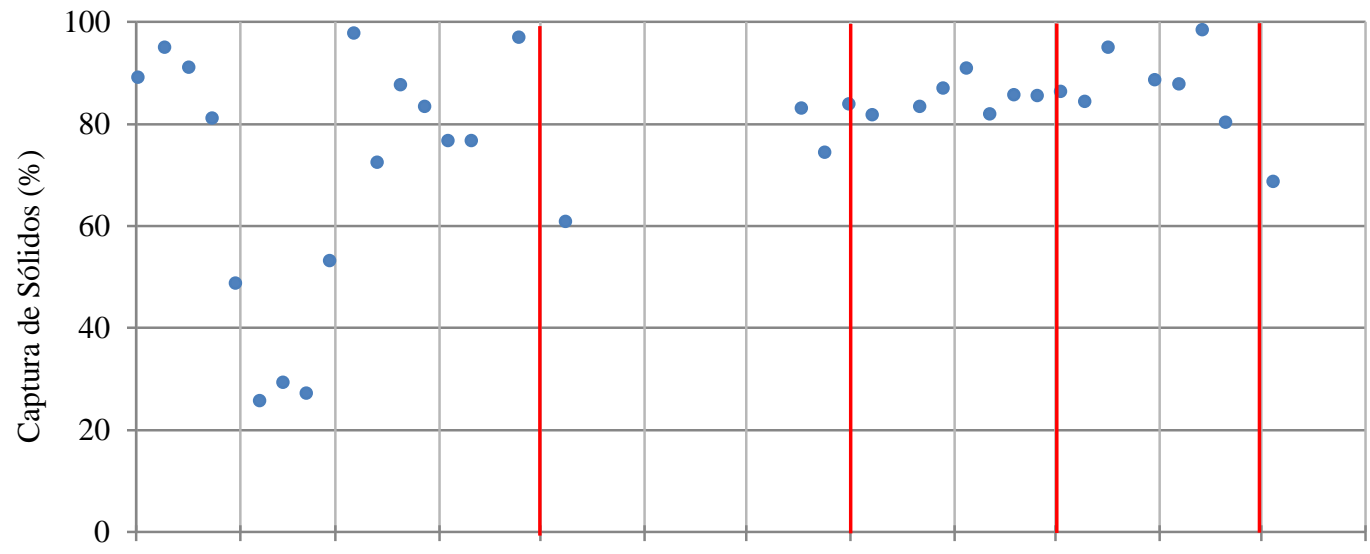

jan-14 fev-14 mar-14 abr-14 mai-14 jun-14 jul-14 ago-14 set-14 out-14 nov-14 dez-14

Figura 5.36 - Série temporal de captura de sólidos no adensador no ano de 2014.

Pela observação da Figura 5.36 nota-se que o ciclo com melhor resposta foi o Ciclo 3, com capturas dentro da faixa típica para o adensamento por gravidade, entretanto, o Ciclo 2 mostra-se vantajoso à medida em que apresenta valores de captura satisfatórios e um volume de lodo primário cerca de $10 \%$ menor que o usualmente adotado pelos operadores da ETE.

Uma das hipóteses levantadas para explicar o comportamento atípico do adensador por gravidade na ETE Brasília Norte em 2014, foi a frequência elevada de aporte de óleos e graxas no afluente à estação, relatada pelos operadores do sistema, oriundos de lançamentos indevidos na rede coletora de esgotos de resíduos de caixa de gordura.

O tempo de detenção hidráulica também foi avaliado e pode ser visualizado na Figura 5.37 a seguir.

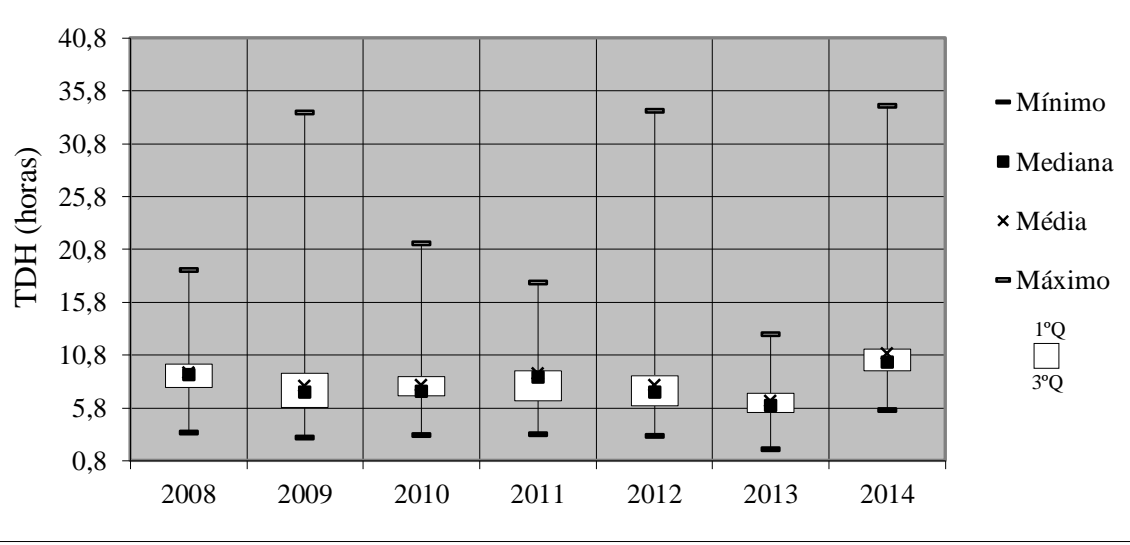

Figura 5. 37 - Box-plot do tempo de detenção hidráulica no adensador por gravidade 
Segundo o que pode ser observado, os tempos de detenção hidráulica, ao longo do tempo de operação monitorado, estiveram dentro do preconizado pela ABNT (2011) que apresenta valor máximo de TDH de 24 horas, para adensador por gravidade. Os casos de máximos observados podem estar relacionados com paralisações para manutenção da unidade de decantação primária.

Os dados analisados ao longo do período, indicam que o adensador por gravidade da ETEB Norte apresenta bom desempenho, no tocante à captura de sólidos, mesmo com cargas acima da recomendada na literatura, com bons resultados para TAS até $300 \mathrm{kgST} / \mathrm{m}^{2} . \mathrm{d}$. Entretanto, eles sugerem a necessidade de uma investigação mais aprofundada para averiguação da coerência nos resultados obtidos, estudando parâmetros como as características das partículas (lodo com concentração elevada de óleos e graxas), e como eles interferem na velocidade de sedimentação e, por conseguinte, na eficiência da unidade.

\subsubsection{Adensador por flotação}

O adensamento por flotação com ar dissolvido tem sua maior aplicação para o adensamento de lodo excedente, proveniente dos reatores biológicos do processo de lodos ativados (ABNT, 2011).

No adensamento por flotação na ETEB Norte não são utilizados polímeros para condicionamento do lodo, assim o lodo excedente do reator biológico é bombeado diretamente para as unidades de adensamento.

Segundo o que recomenda a ABNT (2011), entre os parâmetros a serem considerados no dimensionamento de adensadores por flotação estão a taxa de aplicação de sólidos e o teor de sólidos. Neste estudo, a captura de sólidos também foi avaliada, de maneira a estabelecer o comportamento do lodo, e os resultados são apresentados a seguir (Figura $5.38)$. 


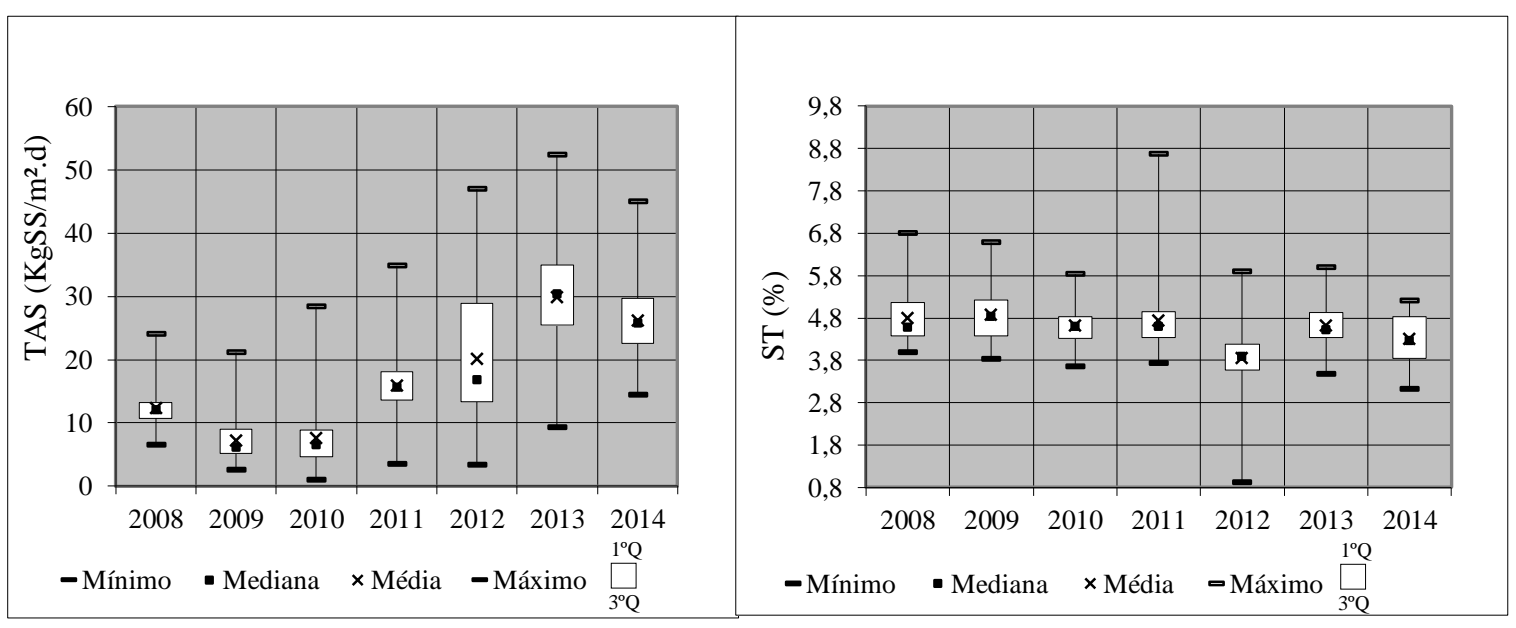

Figura 5.38 - Box-plot da taxa de aplicação de sólidos (TAS) e Teor de ST(\%) no lodo adensado por flotação da ETEB Norte

Os valores observados na Figura 5.38 mostram que as taxas de aplicação de sólidos ao longo dos anos de operação da unidade monitorados, estão bem abaixo dos limites recomendados na literatura, que seriam de 50 a $120 \mathrm{Kg} / \mathrm{m}^{2} . \mathrm{d}$, e as concentrações médias de sólidos totais apresentam-se dentro da faixa típica para lodo aeróbio adensado por flotação, com valores variando entre 3,86 a 4,87\%, pois, conforme Metcalf \& Eddy (2003), o teor de sólidos do lodo secundário flotado pode atingir valores entre 3 e $6 \%$.

Nota-se, ainda, um aumento na taxa de aplicação de sólidos a partir do ano de 2012, com valores que foram de $15,9 \mathrm{kgSS} / \mathrm{m}^{2} . \mathrm{d}$ (2011), para 20,0 $\mathrm{kgSS} / \mathrm{m}^{2} . \mathrm{d}$ e $29,85 \mathrm{kgSS} / \mathrm{m}^{2} . \mathrm{d}$ em 2012 e 2013, respectivamente, o que pode ser facilmente explicado pela entrada em operação de um terceiro reator biológico no final de 2012, medida adotada para melhorar a eficiência do tratamento de esgotos e conter a perda excessiva de sólidos no efluente dos decantadores secundários da ETE.

Com isso, o volume de lodo excedente foi acrescido, correspondendo ao aumento percebido no volume afluente ao adensador. Outra consideração importante é que os adensadores foram projetados para um volume de lodo oriundo do descarte de quatro reatores biológicos, com idade de lodo estimada em 10 dias e a realidade operacional verificada são idades de lodo variando entre 12 e 15 dias, para 2 reatores até 2012 e 3 reatores a partir de setembro de 2012.

Para o cálculo da TAS e da captura de sólidos, foram levantados os volumes de lodo proveniente dos adensadores. Esses adentram um poço de bombeamento que recalca o lodo para o digestor primário anaeróbio e que também recebe o lodo químico via bombeamento. 
Até maio de 2013 não havia medidores de vazão em quaisquer dessas linhas. Dessa forma, o volume de lodo produzido era estimado em função do número de horas de bombeamento e das vazões das bombas dos respectivos poços, considerando o volume bombeado desse poço, menos o volume de lodo químico. Essa metodologia de controle dava origem a dados inconsistentes, sempre que havia problemas com os horímetros ou perda de eficiência das bombas.

Por essa razão, dos 2.494 dados de vazão verificados, apenas 1.527 foram considerados válidos, os demais foram descartados por apresentarem volumes negativos ou serem considerados expurgos a partir do tratamento estatístico, que eliminou dados que estavam fora dos limites do $1^{\mathrm{o}}$ e $3^{\circ}$ quartis. A Figura 5.39 mostra os dados de captura de sólidos e taxa de aplicação de sólidos nos adensadores por flotação.

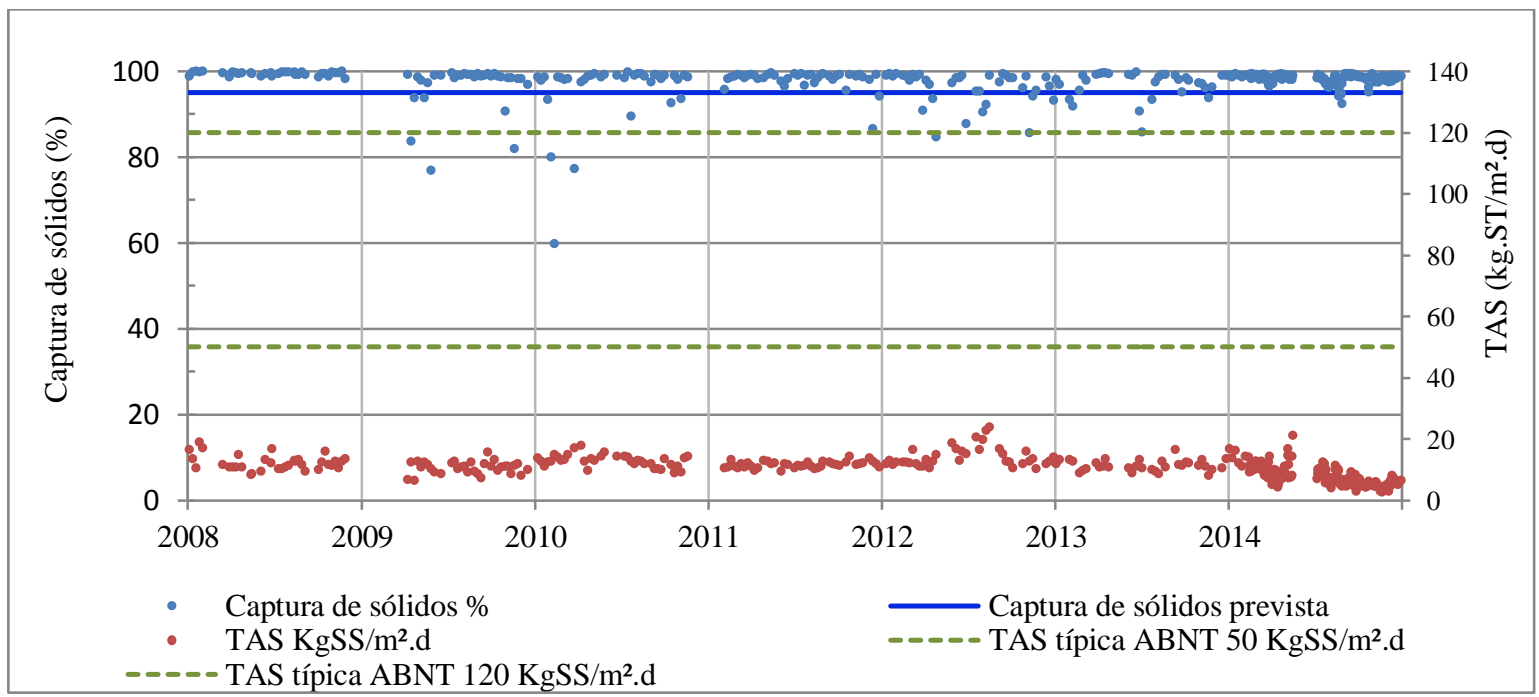

Figura 5.39 - Série temporal da Taxa de Aplicação de Sólidos e captura de sólidos dos adensadores por flotação da ETEB Norte

Pela Figura 5.39, verifica-se que não foi possível estabelecer uma inter-relação entre as taxas de aplicação de sólidos (TAS) e a captura dos mesmos. Entre as possíveis justificativas para o comportamento observado, estão as baixas taxas de aplicação de sólidos. A captura de sólidos esteve, ao longo do tempo monitorado, acima dos valores estabelecidos pela literatura, que estabelece captura máxima de $95 \%$, demonstrando que os adensadores por flotação operam de forma satisfatória, com eficiência acima do reportado pelos especialistas. 


\subsubsection{Câmaras de flotação do polimento final}

A unidade de tratamento avançado na ETE Brasília Norte compreende uma etapa de polimento químico, detalhada no item 5.2.1.4. Essa etapa não abrange o tratamento da fase sólida e a relevância da sua avaliação se justifica pela produção de lodo químico, proveniente da perda de sólidos nos decantadores secundários e da remoção de materiais solúveis remanescentes do processo biológico.

No projeto original da unidade, o lodo químico seria direcionado para a desidratação mecânica, podendo se juntar aos demais lodos no digestor secundário. Entretanto, desde 2005, quando o digestor aeróbio foi desativado, o lodo químico passou a ser enviado diretamente ao digestor anaeróbio primário. Com isso, o processo de estabilização de lodos é diretamente afetado pela produção de lodo químico, impactando a carga orgânica volumétrica e o tempo de residência celular.

A Tabela 5.23 e Figuras 5.40 e 5.41 apresentam os dados relativos à produção de lodo químico e às concentrações no lodo químico, ao longo dos anos monitorados.

Tabela 5.23 - Estatística descritiva dos parâmetros de controle do lodo químico da ETEB Norte

\begin{tabular}{|c|c|c|c|c|c|c|c|c|}
\hline $\begin{array}{l}\text { Parâmetro de } \\
\text { controle }\end{array}$ & Estatística & 2008 & 2009 & 2010 & 2011 & 2012 & 2013 & 2014 \\
\hline \multirow{6}{*}{$\begin{array}{l}\text { Volume de lodo } \\
\text { químico }\end{array}$} & $1^{\circ} \mathrm{Q}$ & 38 & 132 & 147 & 180 & 160 & 131 & 143 \\
\hline & Mínimo & 15 & 43 & 75 & 120 & 80 & 24 & 0 \\
\hline & Mediana & 55 & 199 & 188 & 240 & 200 & 191 & 216 \\
\hline & Média & 56 & 203 & 208 & 248 & 217 & 196 & 200 \\
\hline & Máximo & 160 & 535 & 420 & 480 & 520 & 445 & 415 \\
\hline & $3^{\circ} \mathrm{Q}$ & 70 & 244 & 255 & 280 & 240 & 260 & 250 \\
\hline \multirow{6}{*}{$\begin{array}{c}\text { Concentração de } \\
\text { ST no lodo } \\
\text { químico }\end{array}$} & $1^{\circ} \mathrm{Q}$ & 1,41 & 1,49 & 1,57 & 1,58 & 1,41 & 1,25 & 1,62 \\
\hline & Mínimo & 0,92 & 0,84 & 0,94 & 0,73 & 0,92 & 0,95 & 1,05 \\
\hline & Mediana & 1,57 & 1,76 & 1,85 & 1,76 & 1,52 & 1,60 & 1,83 \\
\hline & Média & 1,69 & 1,75 & 1,86 & 1,80 & 1,55 & 1,56 & 1,80 \\
\hline & Máximo & 3,18 & 2,57 & 3,28 & 2,68 & 2,15 & 2,89 & 2,32 \\
\hline & $3^{\circ} \mathrm{Q}$ & 1,91 & 2,04 & 2,03 & 2,04 & 1,75 & 1,77 & 1,98 \\
\hline
\end{tabular}




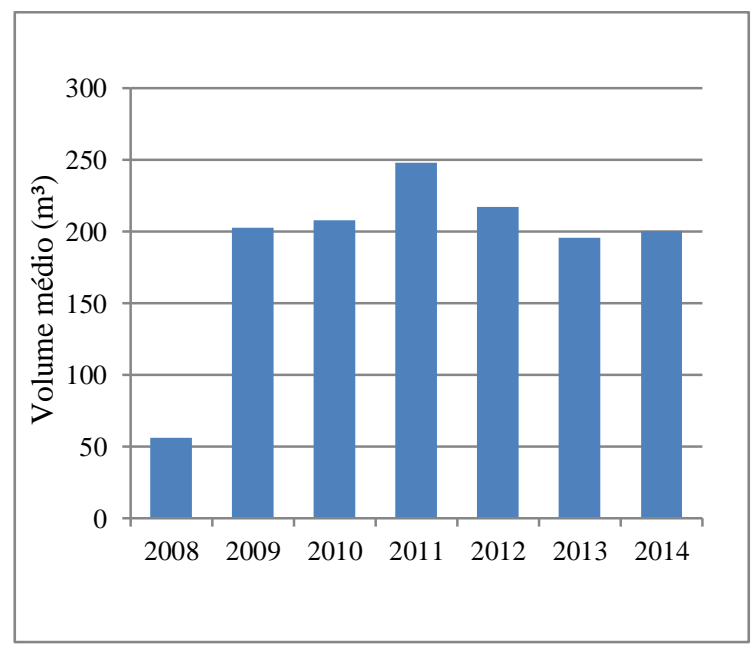

Figura 5.40 -Volume médio diário de lodo químico gerado na ETEB Norte $\left(\mathrm{m}^{3}\right)$ anos $2008-2014$

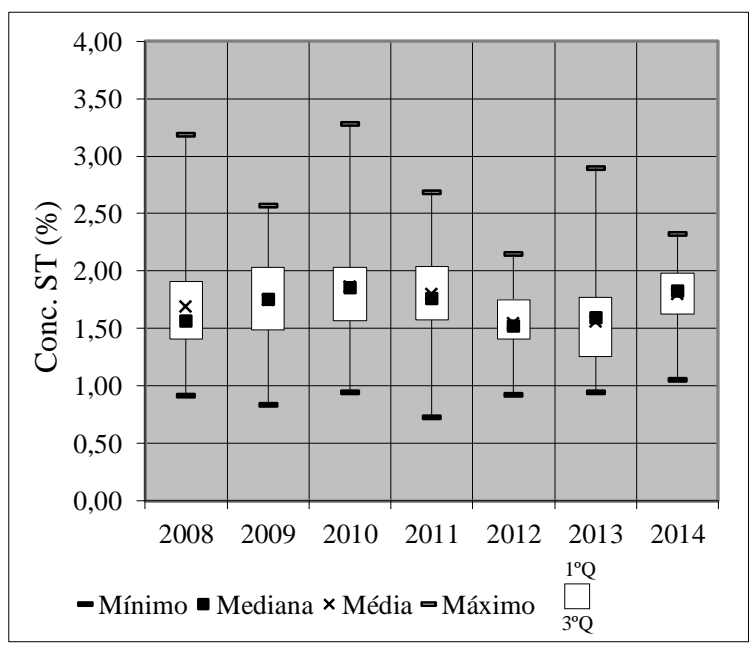

Figura 5.41 - Box-plot da concentração de sólidos (\%ST) de lodo químico gerado na ETEB

Norte, anos de 2008 - 2014

Conforme apresentado nas Figuras 5.40 e 5.41, houve um aumento expressivo no volume de lodo químico produzido no decorrer do período monitorado, da mesma maneira, as concentrações de sólidos no lodo químico apresentaram queda entre os anos de 2012 e 2013. Medidas operacionais para otimização do tratamento químico, como por exemplo, a recirculação de lodo flotado para o início das câmaras de floculação e a introdução de dosagem de cal, para promover uma melhor floculação, favoreceram o aumento da concentração de lodo, percebida em 2014.

\subsubsection{Digestor anaeróbio primário}

A concepção original do processo de digestão na ETE Brasília Norte previa a digestão anaeróbia apenas do lodo primário, o lodo secundário seria direcionado para digestores aeróbios e, posteriormente, esses lodos seriam reunidos no digestor secundário, seguindo dali para a desidratação. Desde 2000, entretanto, o digestor aeróbio foi desativado e todo o lodo produzido no sistema é encaminhado desde então para os digestores anaeróbios. As cargas de sólidos afluente ao digestor anaeróbio, produzida em cada etapa, ao longo do período em análise, é indicada na Tabela 5.24.

O levantamento das informações de projeto, no tocante à constituição dos lodos gerados na ETE, indicou que a estimativa inicial previa, em termos percentuais, as seguintes parcelas de lodo: $30 \%$ lodo primário, $60 \%$ lodo aeróbio e $10 \%$ lodo químico. Pela observação da tabela 5.24, verifica-se acentuada discrepância entre os valores estimados e as cargas de lodo produzidas nas etapas de lodo aeróbio adensado e lodo químico. 
Os volumes de lodo primário são diretamente influenciados pelas características dos esgotos afluentes e pelo desempenho da unidade de adensamento, que se mostrou estável ao longo dos anos, conforme considerações do item 5.2.2.2, razão pelo que se observa que os percentuais mostraram-se dentro do previsto em projeto. No entanto, a geração de lodo aeróbio e de lodo químico é diretamente afetada pelo equilíbrio do processo biológico do tratamento de esgotos; isso poderia explicar a variabilidade verificada ao longo do período monitorado, entre esses dois tipos de lodo.

Tabela 5.24 - Carga de sólidos aplicada aos digestores anaeróbios por tipo de lodo, em $\mathrm{KgSS} / \mathrm{d}$.

\begin{tabular}{|c|c|c|c|c|c|c|c|c|}
\hline \multirow{2}{*}{ ETAPA } & \multirow{2}{*}{$\begin{array}{l}\text { Estatística } \\
\text { Descritiva }\end{array}$} & \multicolumn{7}{|c|}{ Cargas de sólidos aplicada $\mathrm{KgSS} / \mathrm{d}$} \\
\hline & & 2008 & 2009 & 2010 & 2011 & 2012 & 2013 & 2014 \\
\hline \multirow{6}{*}{$\begin{array}{c}\text { LODO } \\
\text { AERÓBIO } \\
\text { ADENSADO }\end{array}$} & $1^{\circ} \mathrm{Q}$ & 13.041 & 5.875 & 2.643 & 3.138 & 1.058 & 5.916 & 4.157 \\
\hline & Mínimo & 5.047 & 858 & 892 & 1.030 & 734 & 3.157 & 2.745 \\
\hline & Mediana & 16.044 & 7.190 & 6.050 & 5.011 & 2.989 & 7.064 & 5.722 \\
\hline & Média & 16.512 & 7.545 & 6.091 & 6.352 & 2.604 & 7.063 & 5.922 \\
\hline & Máximo & 28.613 & 21.796 & 18.962 & 21.148 & 5.200 & 10.153 & 11.657 \\
\hline & $3^{\circ} \mathrm{Q}$ & 20.346 & 8.246 & 6.790 & 8.598 & 3.037 & 8.464 & 6.672 \\
\hline \multirow{6}{*}{$\begin{array}{c}\text { LODO } \\
\text { PRIMÁRIO } \\
\text { ADENSADO }\end{array}$} & $1^{\circ} \mathrm{Q}$ & 4.830 & 3.813 & 3.225 & 3.530 & 3.603 & 2.768 & 2.997 \\
\hline & Mínimo & 1.956 & 1.998 & 689 & 907 & 1.823 & 1.329 & 1.047 \\
\hline & Mediana & 5.959 & 5.219 & 4.111 & 4.483 & 4.213 & 3.503 & 3.611 \\
\hline & Média & 6.128 & 5.239 & 4.435 & 4.427 & 4.655 & 3.591 & 4.346 \\
\hline & Máximo & 12.143 & 9.616 & 10.271 & 7.749 & 10.644 & 6.337 & 26.008 \\
\hline & $3^{\circ} \mathrm{Q}$ & 7.797 & 6.722 & 5.408 & 5.101 & 5.780 & 4.351 & 4.144 \\
\hline \multirow{6}{*}{$\begin{array}{c}\text { LODO } \\
\text { QUÍMICO }\end{array}$} & $1^{\circ} \mathrm{Q}$ & 613 & 2.767 & 3.615 & 3.748 & 2.501 & 2.409 & 1.758 \\
\hline & Mínimo & 259 & 1.197 & 1.888 & 2.344 & 1.910 & 1.475 & - \\
\hline & Mediana & 992 & 3.658 & 4.370 & 5.338 & 4.000 & 3.723 & 4.080 \\
\hline & Média & 1.084 & 4.076 & 5.092 & 5.450 & 3.964 & 3.986 & 4.123 \\
\hline & Máximo & 3.992 & 9.138 & 13.827 & 11.597 & 7.291 & 8.054 & 10.615 \\
\hline & $3^{\circ} \mathrm{Q}$ & 1.258 & 5.049 & 6.119 & 6.802 & 4.830 & 5.034 & 5.917 \\
\hline \multicolumn{2}{|c|}{ TOTAL } & 23.724 & 16.859 & 15.618 & 16.229 & 11.222 & 14.639 & 14.391 \\
\hline \multicolumn{2}{|c|}{ LODO AERÓBIO ADENSADO } & $69,6 \%$ & $44,8 \%$ & $39,0 \%$ & $39,1 \%$ & $23,2 \%$ & $48,2 \%$ & $41,2 \%$ \\
\hline \multicolumn{2}{|c|}{ LODO PRIMÁRIO ADENSADO } & $25,8 \%$ & $31,1 \%$ & $28,4 \%$ & $27,3 \%$ & $41,5 \%$ & $24,5 \%$ & $30,2 \%$ \\
\hline \multicolumn{2}{|c|}{ LODO QUÍMICO } & $4,6 \%$ & $24,2 \%$ & $32,6 \%$ & $33,6 \%$ & $35,3 \%$ & $27,2 \%$ & $28,6 \%$ \\
\hline
\end{tabular}

Considerando as condições de projeto da unidade de digestão de lodo, mencionada a princípio, os digestores primários recebem uma carga de sólidos de cerca de 130\% (lodo aeróbio + lodo químico) acima do inicialmente proposto.

Para a análise do desempenho da etapa de digestão de lodo, foram levantados dados relacionados ao teor de sólidos totais e sólidos totais voláteis no digestor, a relação STV/ST, a carga orgânica volumétrica afluente ao digestor, o tempo de digestão, a relação alcalinidade total e acidez volátil e o $\mathrm{pH}$. Os resultados podem ser visualizados na Tabela 5.25 e Figuras 5.42 a 5.52 a seguir. 
Tabela 5.25 - Parâmetros operacionais de controle do processo de digestão anaeróbia da ETEB Norte

\begin{tabular}{|c|c|c|c|c|c|c|c|c|}
\hline Parâmetro & Estatística & 2008 & 2009 & 2010 & 2011 & 2012 & 2013 & 2014 \\
\hline \multirow{7}{*}{$\begin{array}{c}\text { Teor de sólidos } \\
\text { \% ST }\end{array}$} & $1^{\circ} \mathrm{Q}$ & 1,91 & 2,15 & 2,05 & 1,83 & 1,86 & 2,28 & 2,19 \\
\hline & Mínimo & 1,40 & 1,95 & 1,65 & 1,66 & 1,63 & 2,11 & 1,96 \\
\hline & Mediana & 2,11 & 2,32 & 2,23 & 2,02 & 1,93 & 2,44 & 2,27 \\
\hline & Média & 2,20 & 2,36 & 2,22 & 2,05 & 1,99 & 2,44 & 2,29 \\
\hline & Máximo & 3,75 & 3,45 & 2,85 & 2,69 & 2,44 & 2,86 & 2,72 \\
\hline & $3^{\circ} \mathrm{Q}$ & 2,45 & 2,50 & 2,42 & 2,24 & 2,13 & 2,59 & 2,40 \\
\hline & Desvio padrão & 0,41 & 0,31 & 0,30 & 0,26 & 0,17 & 0,20 & 0,17 \\
\hline \multirow{7}{*}{$\begin{array}{l}\text { Teor de sólidos } \\
\text { voláteis } \\
\text { \%STV }\end{array}$} & $1^{\circ} \mathrm{Q}$ & 1,32 & 1,55 & 1,38 & 1,31 & 1,33 & 1,59 & 1,47 \\
\hline & Mínimo & 1,14 & 1,27 & 1,10 & 1,05 & 1,19 & 0,84 & 1,31 \\
\hline & Mediana & 1,51 & 1,74 & 1,50 & 1,42 & 1,38 & 1,66 & 1,56 \\
\hline & Média & 1,62 & 1,77 & 1,53 & 1,44 & 1,40 & 1,67 & 1,57 \\
\hline & Máximo & 2,99 & 2,62 & 2,26 & 2,14 & 1,90 & 1,99 & 1,83 \\
\hline & $3^{\circ} \mathrm{Q}$ & 1,83 & 1,95 & 1,64 & 1,57 & 1,47 & 1,77 & 1,68 \\
\hline & Desvio padrão & 0,39 & 0,32 & 0,26 & 0,23 & 0,12 & 0,14 & 0,13 \\
\hline \multirow{7}{*}{$\begin{array}{l}\mathrm{COV} \text { - Carga } \\
\text { Orgânica } \\
\text { volumétrica } \\
\mathrm{KgSTV} / \mathrm{m}^{3} . \mathrm{d}\end{array}$} & $1^{\circ} \mathrm{Q}$ & 2,65 & 1,91 & 1,36 & 1,67 & 1,33 & 1,66 & 1,48 \\
\hline & Mínimo & 1,27 & 1,19 & 1,30 & 1,08 & 1,17 & 1,13 & 1,25 \\
\hline & Mediana & 3,00 & 2,64 & 2,07 & 2,02 & 1,49 & 1,95 & 1,66 \\
\hline & \begin{tabular}{|l|} 
Média \\
\end{tabular} & 3,09 & 2,46 & 2,11 & 2,25 & 1,43 & 1,91 & 1,79 \\
\hline & \begin{tabular}{|l|} 
Máximo \\
\end{tabular} & 4,86 & 4,28 & 3,16 & 4,61 & 1,59 & 2,59 & 2,73 \\
\hline & $3^{\circ} \mathrm{Q}$ & 3,51 & 2,82 & 2,64 & 2,38 & 1,59 & 2,15 & 2,18 \\
\hline & Desvio padrão & 0,79 & 0,80 & 0,72 & 0,93 & 0,20 & 0,36 & 0,41 \\
\hline \multirow{7}{*}{$\begin{array}{c}\text { TDH - Tempo de } \\
\text { detenção hidráulica } \\
\text { dias }\end{array}$} & $1^{\circ} \mathrm{Q}$ & 11 & 12 & 14 & 13 & 15 & 14 & 15 \\
\hline & \begin{tabular}{|l|} 
Mínimo \\
\end{tabular} & 8 & 9 & 9 & 8 & 8 & 10 & 8 \\
\hline & \begin{tabular}{|l|} 
Mediana \\
\end{tabular} & 13 & 15 & 16 & 16 & 18 & 17 & 16 \\
\hline & Média & 13 & 16 & 17 & 15 & 18 & 17 & 17 \\
\hline & Máximo & 27 & 31 & 25 & 23 & 29 & 29 & 28 \\
\hline & $3^{\circ} \mathrm{Q}$ & 15 & 19 & 19 & 17 & 21 & 19 & 19 \\
\hline & Desvio padrão & 4 & 5 & 4 & 4 & 5 & 4 & 4 \\
\hline \multirow{7}{*}{ SV/ST } & $1^{\circ} \mathrm{Q}$ & 0,69 & 0,68 & 0,66 & 0,68 & 0,69 & 0,67 & 0,65 \\
\hline & Mínimo & 0,60 & 0,64 & 0,61 & 0,57 & 0,65 & 0,30 & 0,57 \\
\hline & Mediana & 0,71 & 0,73 & 0,68 & 0,71 & 0,71 & 0,70 & 0,69 \\
\hline & \begin{tabular}{|l|} 
Média \\
\end{tabular} & 0,73 & 0,75 & 0,69 & 0,70 & 0,71 & 0,68 & 0,69 \\
\hline & Máximo & 0,86 & 0,96 & 0,83 & 0,80 & 0,78 & 0,75 & 0,82 \\
\hline & $3^{\circ} \mathrm{Q}$ & 0,78 & 0,80 & 0,70 & 0,73 & 0,72 & 0,72 & 0,71 \\
\hline & Desvio padrão & 0,10 & 0,08 & 0,04 & 0,04 & 0,03 & 0,03 & 0,05 \\
\hline \multirow{7}{*}{$\begin{array}{c}\text { Acidez/ } \\
\text { Alcalinide }\end{array}$} & $1^{\circ} \mathrm{Q}$ & 0,14 & 0,14 & 0,11 & 0,11 & 0,09 & 0,12 & 0,15 \\
\hline & \begin{tabular}{|l|} 
Mínimo \\
\end{tabular} & 0,06 & 0,08 & 0,04 & 0,08 & 0,07 & 0,09 & 0,10 \\
\hline & Mediana & 0,18 & 0,20 & 0,13 & 0,15 & 0,12 & 0,13 & 0,16 \\
\hline & Média & 0,19 & 0,20 & 0,14 & 0,15 & 0,14 & 0,15 & 0,16 \\
\hline & Máximo & 0,37 & 0,48 & 0,40 & 0,29 & 0,55 & 0,30 & 0,26 \\
\hline & $3^{\circ} \mathrm{Q}$ & 0,26 & 0,23 & 0,17 & 0,16 & 0,16 & 0,17 & 0,18 \\
\hline & Desvio padrão & 0,07 & 0,08 & 0,06 & 0,05 & 0,08 & 0,05 & 0,03 \\
\hline \multirow{7}{*}{$\begin{array}{c}\text { Eficiência na } \\
\text { remoção de sólidos } \\
\text { voláteis } \\
\%\end{array}$} & $1^{\circ} \mathrm{Q}$ & 49 & 32 & 35 & 44 & 44 & 41 & 37 \\
\hline & \begin{tabular}{|l|} 
Mínimo \\
\end{tabular} & 19 & 22 & 30 & 41 & 44 & 33 & 32 \\
\hline & Mediana & 59 & 42 & 40 & 46 & 45 & 44 & 40 \\
\hline & Média & 56 & 39 & 41 & 48 & 45 & 43 & 39 \\
\hline & Máximo & 74 & 60 & 52 & 57 & 46 & 50 & 46 \\
\hline & $3^{\circ} \mathrm{Q}$ & 65 & 44 & 46 & 51 & 45 & 46 & 42 \\
\hline & Desvio padrão & 12 & 11 & 11 & 5 & 8 & 10 & 5 \\
\hline
\end{tabular}




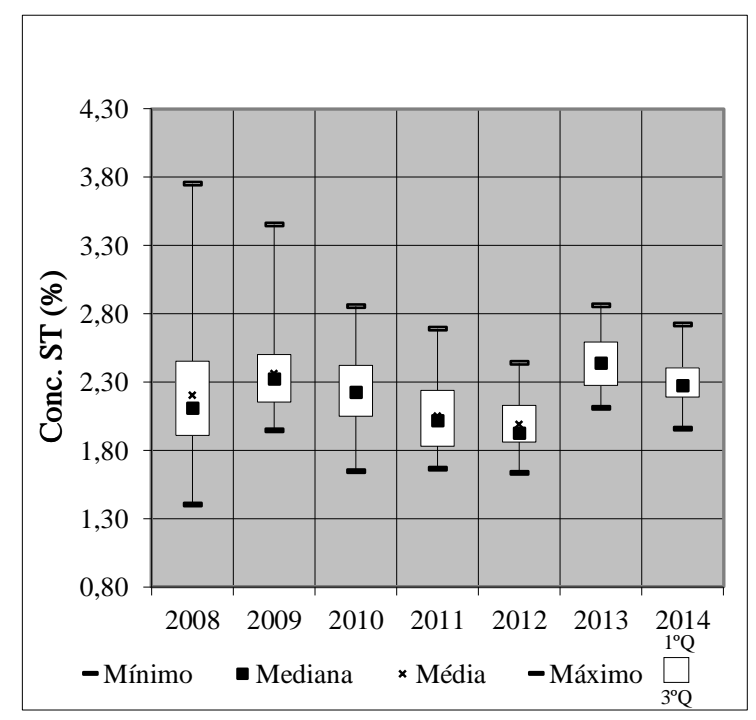

Figura 5.42 - Box-plot da concentração de sólidos totais no lodo digerido

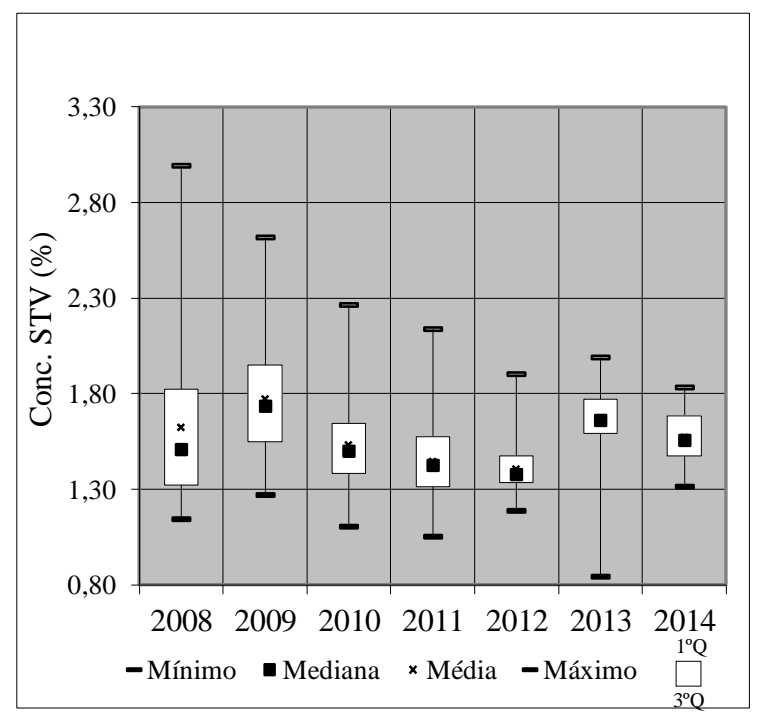

Figura 5.43 - Box-plot da concentração de sólidos totais voláteis no lodo digerido

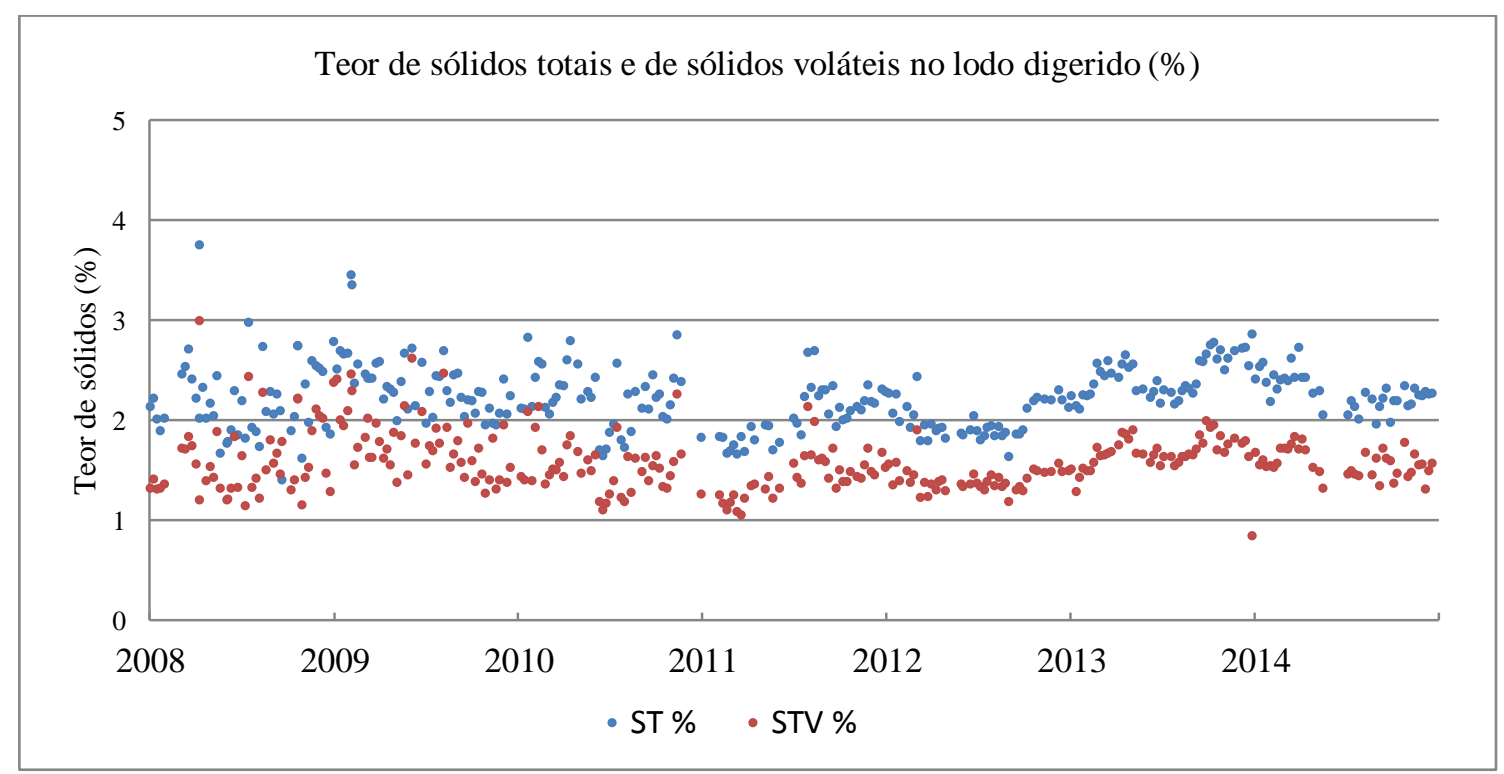

Figura 5.44 - Série temporal das concentrações de sólidos totais e sólidos totais voláteis no lodo digerido.

Como pode ser observado nas Figuras 5.42 a 5.44, as concentrações médias de sólidos totais no lodo digerido, nos anos monitorados, apresentaram valores entre 1,99 a 2,44\%, com os quartis variando entre: 1,91 e 2,45\% (2008); 2,15 e 2,50\% (2009); 2,05 e 2,42\% (2010); 1,83 e 2,24\% (2011); 1,86 e 2,13\% (2012); 2,28 e 2,59\% (2013) e 2,19 e 2,40\% (2014). Segundo Jordão e Pessoa (2005), o lodo digerido apresenta teor de sólidos totais da ordem de 3 a $5 \%$, logo a concentração de sólidos totais no lodo proveniente dos digestores 
primários anaeróbios na ETEB Norte esteve abaixo dos valores usuais reportados na literatura clássica, em todos os anos investigados.

No que tange ao teor de sólidos voláteis, as concentrações médias variaram entre 1,44 a 1,77\%. Jordão e Pessoa (2005) citam que a concentração de sólidos voláteis no lodo digerido deve corresponder a cerca de $45 \%$ dos sólidos totais, logo, para a faixa típica citada, esses valores estariam entre 1,35 a 2,70\%. Os valores médios de concentração de sólidos voláteis verificados indicaram resultados dentro da faixa típica, entretanto, a fração de sólidos voláteis no lodo digerido da ETEB Norte corresponde a, aproximadamente, $70 \%$ dos sólidos totais no lodo digerido, o que está bem acima dos valores usuais.

Os digestores anaeróbios de lodo são utilizados principalmente para a estabilização de lodos primários e secundários, oriundos do tratamento de esgotos, com elevada concentração de material particulado, em que o tempo de residência celular tem significativa importância (Chernicharo, 2007). Para sistemas que não dispõem de mecanismos de retenção de sólidos, o tempo de residência celular é equivalente ao tempo de detenção hidráulica, cuja recomendação é de valores entre 15 e 20 dias (Chernicharo, 2007; ABNT, 2011). A Figura 5.45 apresenta a série temporal do tempo de detenção de digestão a que o lodo foi submetido (TDH).

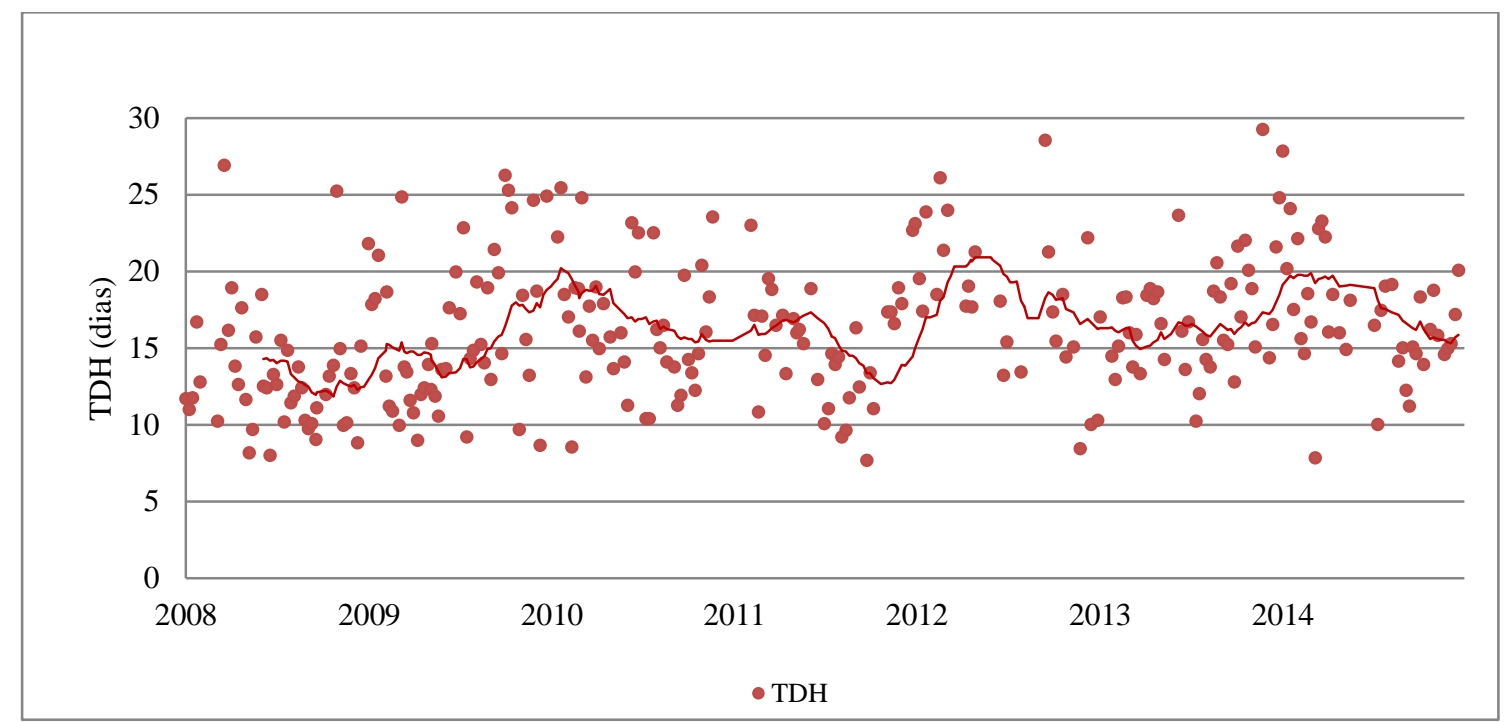

Figura 5.45 - Série temporal do tempo de detenção hidráulica no digestor anaeróbio

Conforme o que se observa pela Figura 5.45, o TDH apresenta uma dispersão significativa, ao longo de todos os anos monitorados. Uma das possíveis explicações para esse comportamento é a variabilidade das frações de lodo químico e aeróbio (lodo excedente), 
que somados correspondem a cerca de $70 \%$ do volume de lodo afluente ao digestor. Como mencionado a princípio, os volumes de lodos gerados nessas etapas estão intrinsecamente ligados ao equilíbrio do processo biológico de tratamento de esgotos, de maneira que a maior ou menor produção de lodo depende das condições operacionais dessas unidades.

Os tempos médios de detenção hidráulica, à exceção de $2008\left(\mathrm{TDH}_{\text {médio: }}: 13\right.$ dias $)$, estiveram dentro da faixa recomendada pelos diferentes autores, ficando entre 16 e 18 dias. Entretanto, os pontos de mínimo e máximo variaram de 8 a 27 dias (2008), 9 - 31 dias (2009), 9 -25 dias (2010), 8 - 23 dias (2011), 8 - 29 dias (2012), 10 - 29 dias (2013) e 8 28 dias (2014), confirmando a influência do aporte de lodo químico e lodo aeróbio adensado no comportamento dessa variável.

Outra variável operacional de interesse é a relação de sólidos voláteis e sólidos totais, que é um indicador do grau de estabilização no lodo digerido. A Resolução CONAMA n³75/2006, estabelece que, para fins de utilização agrícola, o lodo de esgoto ou produto derivado será considerado estável se a relação entre sólidos voláteis e sólidos totais for inferior a 0,70. Jordão e Pessoa (2005) salientam que a fração de sólidos voláteis no lodo digerido deve ser de aproximadamente $45 \%$ dos sólidos totais e von Sperling e Gonçalves (2001) citam que a relação SV/ST no lodo digerido deve situar-se entre 0,60 e 0,65. Pela Figura 5.46 observa-se a série temporal da relação SV/ST no lodo digerido.

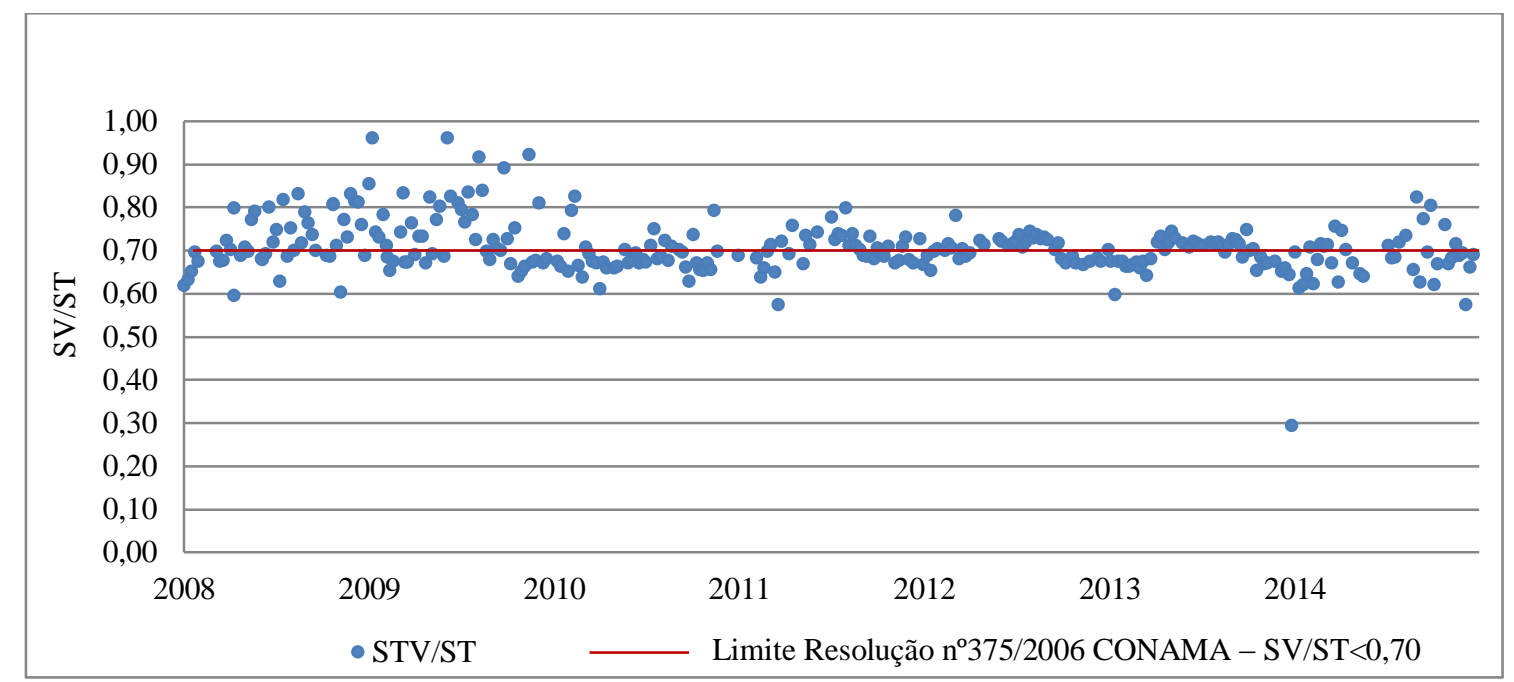

Figura 5.46 - Série temporal de sólidos voláteis e sólidos totais no lodo digerido

Segundo o que se observa pela Figura 5.46, a relação SV/ST no lodo digerido da ETEB Norte situa-se em torno de 0,70. Os valores médios a cada ano foram de: 0,73 (2008); 0,75 
(2009); 0,69 (2010); 0,70 (2011); 0,71 (2012); 0,68 (2013); 0,69 (2014). Conforme pode ser visto, os valores estiveram sempre acima do reportado pelos autores e, considerando o que preconiza a citada Resolução CONAMA, apenas nos anos de 2010, 2013 e 2014 o lodo digerido atenderia à norma quanto ao grau de estabilização.

Vale ressaltar que o sistema de digestão de lodo na ETE Brasília Norte compreende dois digestores anaeróbios primários e um digestor secundário, onde a digestão do lodo é complementada. $\mathrm{O}$ digestor secundário, entretanto, devido à problemas de manutenção, teve prejudicada essa finalidade. Dessa forma, a análise dos parâmetros de controle da digestão primária é importante para compreensão do comportamento do lodo nos digestores primários e para a avaliação do desempenho da unidade, porém, não é conclusiva no que se refere à qualidade final do lodo digerido que segue para a próxima etapa, qual seja o desaguamento de lodo. A recuperação das estruturas e instalações do digestor secundário é primordial para que cumpra sua finalidade e contribua para melhoria do processo de estabilização.

As Figuras 5.47 e 5.48 mostram os gráficos Box-plot do tempo de detenção hidráulica e da relação SV/ST, com as indicações, destacadas em tracejado vermelho, dos TDHs recomendados e do requisito de qualidade da legislação (SV/ST), para aplicação agrícola do lodo.

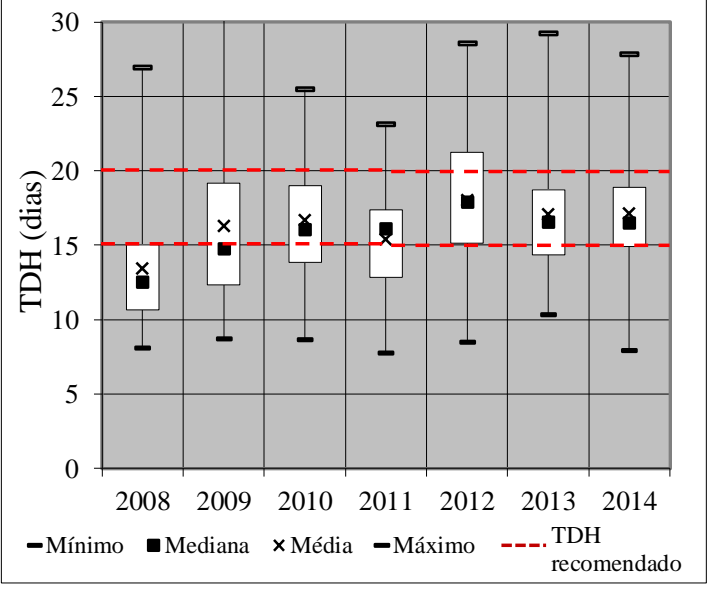

Figura 5.47 - Box-plot do tempo de detenção hidráulica no digestor primário anaeróbio (DGP), em dias

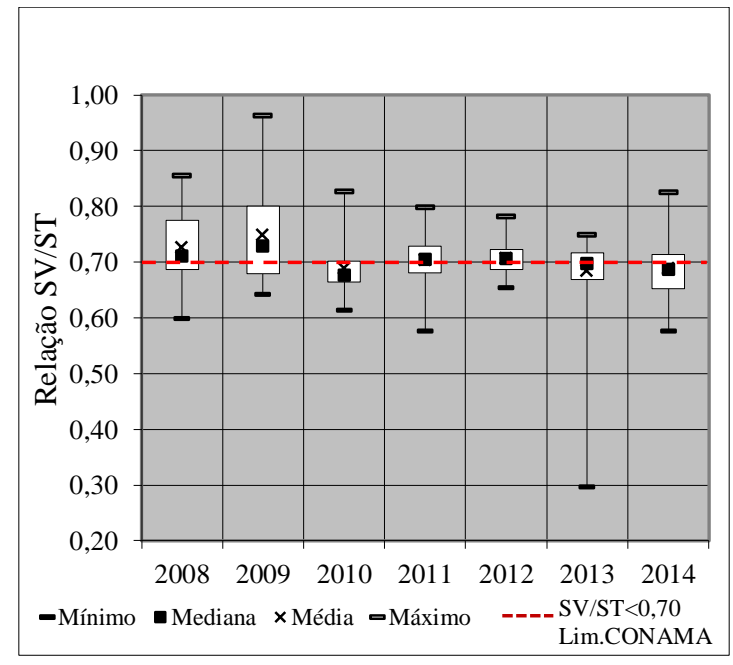

Figura 5.48 - Relação de SV/ST no lodo digerido do DGP da ETEB Norte 
Nota-se pelas figuras 5.47 e 5.48 que, nos anos de 2010, 2013 e 2014, os tempos de detenção hidráulica situaram-se, na maior parte do tempo, dentro da faixa recomendada, de maneira análoga, a relação SV/ST mostrou valores mais baixos no mesmo período, sugerindo uma inter-relação entre as duas variáveis, em que quanto maior o TDH, mais baixa é a relação SV/ST. O ano de 2012 mostrou um comportamento atípico, em que essa inter-relação não foi confirmada.

A eficiência na remoção de sólidos voláteis também foi avaliada ao longo do período e os resultados são apresentados na Figura 5.49.

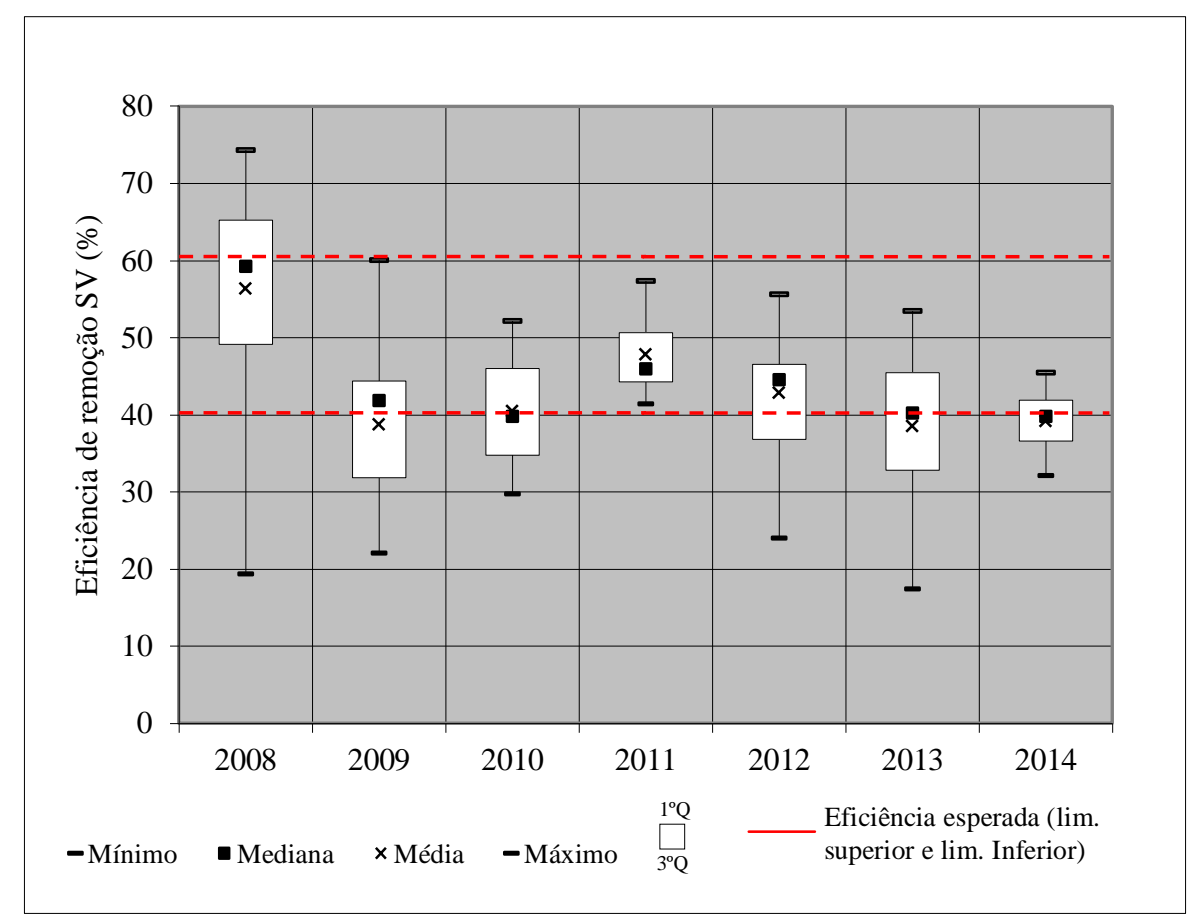

Figura 5.49 - Eficiência de remoção de sólidos voláteis na digestão de lodo da ETEB Norte

Segundo diversos autores, a eficiência de remoção de sólidos voláteis no digestor varia entre 40 e 60\% (von Sperling, Gonçalves, 2001; Jordão e Pessoa, 2005). A ABNT (2011) admite para digestores sem controle de temperatura, caso da ETEB Norte, remoções de 30 a 40\%. Os dados visualizados na Figura 5.45 mostram que as remoções médias de SV no lodo digerido da ETEB Norte variaram de: 56\% (2008); 39\% (2009); 41\% (2010); $48 \%$ (2011); 43\% (2012); 39\% (2013); 39\% (2014). Os valores de redução de sólidos voláteis se mostram baixos segundo os valores típicos, isso denota a necessidade de melhoria do processo de digestão do lodo na ETE. 
A carga de sólidos afluente ao digestor é um dos critérios típicos de dimensionamento do digestor. A literatura especializada admite, para digestores de alta taxa, uma taxa de aplicação de sólidos, denominada como carga orgânica volumétrica (COV), entre 1,6 a 4,8 KgSSV/m³.d (Jordão e Pessoa, 2005; Chernicharo, 2007 e ABNT, 2011). Os valores verificados para carga orgânica volumétrica nos digestores primários da ETEB Norte são apresentados na Figura 5.50.

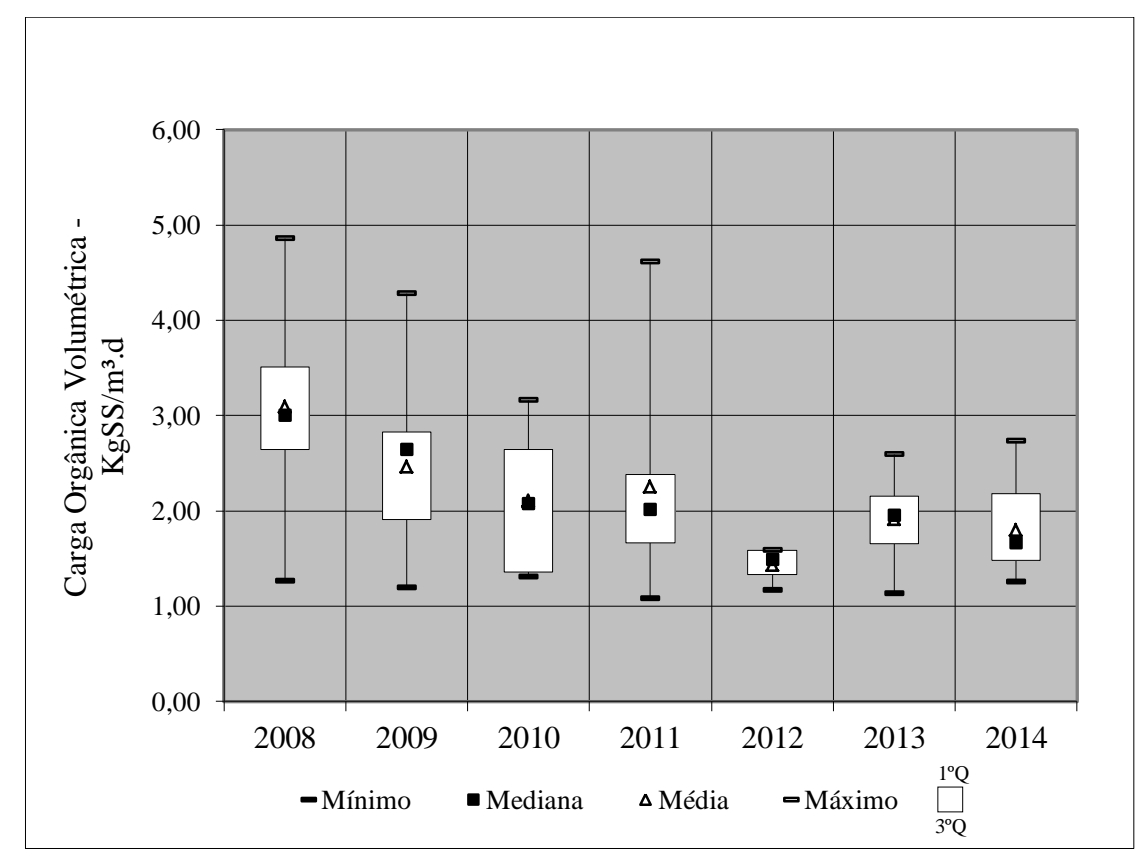

Figura 5.50 - Carga orgânica volumétrica (COV) afluente ao digestor primário anaeróbio da ETEB Norte, em $\mathrm{KgSS} / \mathrm{m}^{3} . \mathrm{d}$

Conforme observado na Figura 5.50 os valores de COV encontram-se dentro da faixa típica para digestores de alta taxa, com valores médios ao longo dos anos monitorados variando de 1,43 a $3,9 \mathrm{KgSS} / \mathrm{m}^{3}$.d. Nota-se que, para $\mathrm{COV}$ mais baixos, caso dos anos de 2012 a 2014, os digestores não apresentaram melhoria na eficiência de remoção de sólidos voláteis, o que indica não ser esse o parâmetro limitante para o alcance da destruição de sólidos voláteis, conforme os valores reportados na literatura para o processo de digestão.

Além das variáveis operacionais discutidas, para a compreensão do comportamento e desempenho do processo de digestão anaeróbia, três fatores ambientais, intimamente relacionados entre si, são de relevante interesse: $\mathrm{pH}$, alcalinidade e acidez volátil (Jordão e Pessoa, 2005; Chernicharo, 2007). 
A interação entre esses fatores fundamenta-se na capacidade da alcalinidade do sistema em neutralizar os ácidos formados no processo e também em tamponar o $\mathrm{pH}$, caso haja acúmulo de ácidos voláteis.

Resumidamente, pode-se dizer que as melhores condições ambientais que favorecem a atividade do digestor anaeróbio são pH entre 6,8 e 7,2 e a relação acidez/alcalinidade variando entre 0,1 e 0,5 (Luduvice, 2001; Jordão e Pessoa, 2005). As Figuras 5.51 e 5.52 mostram a variabilidade dessas variáveis ao longo dos anos monitorados.

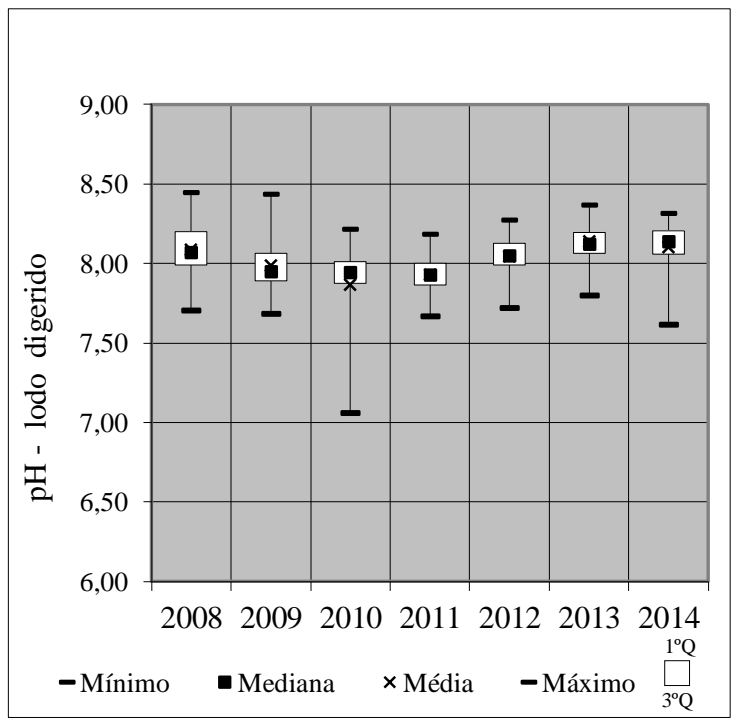

Figura 5.51 - Box-plot do pH no lodo digerido

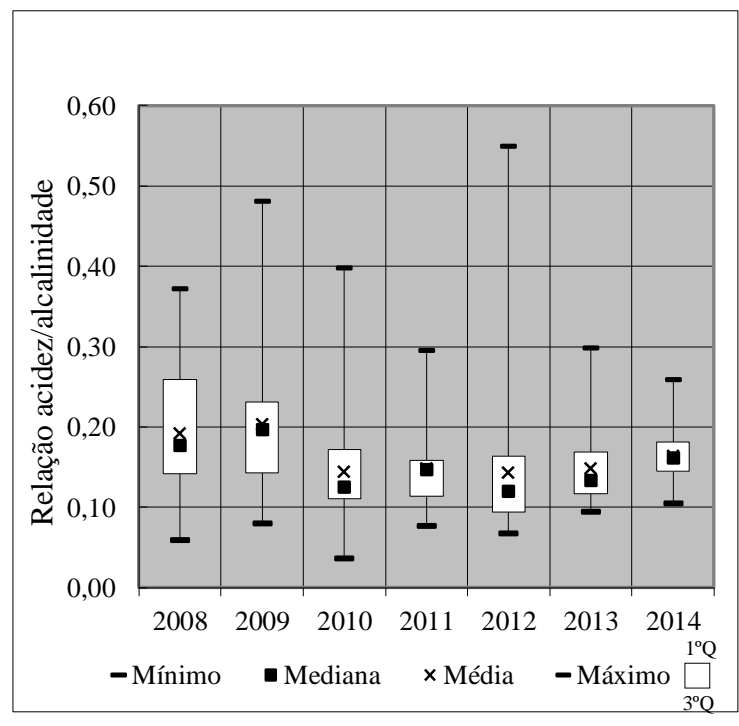

Figura 5.52 - Box-plot da relação acidez/alcalinidade no lodo digerido

$\mathrm{O}$ pH do lodo digerido ao longo dos anos monitorados esteve sempre acima do recomendado pelos diferentes autores, com valores em torno de 8,0. Segundo Chernicharo (2007), é possível conseguir estabilidade na formação de metano na faixa de pH entre 6,0 e 8,0 , entretanto, $\mathrm{pH}$ acima de 8,3 pode inibir o crescimento de microrganismos formadores de metano. Isso denota que o $\mathrm{pH}$ nos digestores primários da ETEB Norte é um fator ambiental da digestão que demanda a adoção de medidas para controle, podendo ser uma das causas da baixa eficiência na remoção de sólidos voláteis e, por conseguinte, das dificuldades para atendimento à relação SV/ST $(<0,70)$ estabelecida na legislação para uso agrícola. Uma medida para diminuir o $\mathrm{pH}$ do lodo seria alterar o regime de alimentação, alternando a carga afluente à cada digestor, entretanto, nas condições atuais de operação das unidades, que apresentam problemas estruturais nas cúpulas de concreto e nas linhas de recirculação do lodo, por segurança, os operadores do sistema tem optado por trabalhar 
com $\mathrm{pH}$ mais altos, prevenindo a acidificação do digestor, de maneira a evitar o transbordamento de lodo pela cúpula, fato que ocorria, segundo relatos, em $\mathrm{pH}$ mais baixos.

A relação acidez/alcalinidade manteve-se, no período verificado, dentro do considerado aceitável para um bom desempenho da digestão do lodo, com valores médios entre 0,14 e 0,20. Os pontos de mínimo e máximo observados referem-se, provavelmente, a desequilíbrios momentâneos no processo de digestão.

\subsubsection{Desaguamento do lodo digerido}

A estação de tratamento de esgotos Brasília Norte promove o desaguamento do lodo por meio de equipamentos mecanizados do tipo prensa de esteira, estando prevista a instalação de centrífuga, ainda em 2015. Apesar de estarem em operação leitos de secagem na ETE, como são utilizados apenas para situações de contingência, esses não serão objeto do presente estudo.

O lodo digerido é condicionado com polímero catiônico na linha de recalque do lodo para as prensas desaguadoras. Como a concentração de sólidos no lodo a ser condicionado afeta o consumo de polímeros, e a literatura relata que o aumento no teor de sólidos do lodo diminui o consumo do polímero, em base seca (Miki, 1998), para efeito desse estudo, a etapa de condicionamento será verificada a partir dos dados de concentração de sólidos no lodo afluente à prensa e consumo de polímeros, em massa de polímero consumido, por massa de torta produzida.

Além desses parâmetros, foram verificados, para avaliar o desempenho da unidade de desidratação mecânica, a carga hidráulica aplicada ao equipamento, a captura de sólidos, o teor de sólidos no lodo desaguado e o volume de lodo desaguado produzido. Os resultados são apresentados na Tabela 5.26 e Figuras 5.53 a 5.58 a seguir. 
Tabela 5.26 - Variáveis operacionais e parâmetros de controle do processo de desaguamento de lodo.

\begin{tabular}{|c|c|c|c|c|c|c|c|c|}
\hline PARÂMETRO & Estatística & 2008 & 2009 & 2010 & 2011 & 2012 & 2013 & 2014 \\
\hline \multirow{7}{*}{$\begin{array}{c}\text { Teor de sólidos } \\
\text { \% ST }\end{array}$} & $1^{\circ} \mathrm{Q}$ & 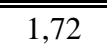 & 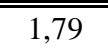 & 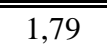 & $\bar{~} 1,69$ & 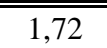 & 2,03 & 2,07 \\
\hline & Mínimo & 1,29 & 1,53 & 1,22 & 1,25 & 1,50 & 1,61 & 1,71 \\
\hline & Mediana & 1,95 & 1,89 & 2,02 & 1,88 & 1,80 & 2,11 & 2,18 \\
\hline & Média & 1,99 & 1,90 & 2,01 & 1,90 & 1,87 & 2,17 & 2,18 \\
\hline & Máximo & 3,69 & 2,40 & 3,46 & 2,95 & 2,66 & 2,66 & 2,59 \\
\hline & $3^{\circ} \mathrm{Q}$ & 2,18 & 1,97 & 2,21 & 2,06 & 2,00 & 2,31 & 2,30 \\
\hline & \begin{tabular}{|l|} 
Desv.padrão \\
\end{tabular} & 0,38 & 0,20 & 0,31 & 0,35 & 0,26 & 0,22 & 0,18 \\
\hline \multirow{7}{*}{$\begin{array}{c}\text { Carga } \\
\text { Hidráulica } \\
\text { aplicada à } \\
\text { prensa } \\
\mathrm{m}^{3} / \mathrm{h}\end{array}$} & $1^{\circ} \mathrm{Q}$ & 13,02 & 13,98 & 12,77 & 15,01 & 13,23 & 16,65 & 18,13 \\
\hline & Mínimo & 8,89 & 7,98 & 9,57 & 11,17 & 5,46 & 11,70 & 17,25 \\
\hline & Mediana & 15,18 & 15,96 & 14,43 & 18,80 & 15,81 & 20,66 & 18,71 \\
\hline & Média & 14,14 & 14,79 & 15,44 & 17,79 & 15,34 & 18,98 & 19,87 \\
\hline & Máximo & 17,17 & 18,00 & 21,72 & 22,51 & 20,12 & 22,32 & 23,66 \\
\hline & $3^{\circ} \mathrm{Q}$ & 15,84 & 17,01 & 18,69 & 20,31 & 19,24 & 21,78 & 22,19 \\
\hline & \begin{tabular}{|l|} 
Desv.padrão \\
\end{tabular} & 2,5 & 3,3 & 4,1 & 3,6 & 4,6 & 4,0 & 2,5 \\
\hline \multirow{7}{*}{ 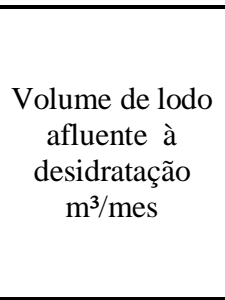 } & $1^{\circ} \mathrm{Q}$ & 13.548 & 14.290 & 13.601 & 18.196 & 16.138 & 11.039 & 11.819 \\
\hline & Mínimo & 8.980 & 8.315 & 10.885 & 13.574 & 16.86 & 9.555 & 10.862 \\
\hline & Mediana & 14.846 & 15.603 & 15.239 & 22.806 & 19.954 & 12.351 & 12.352 \\
\hline & Média & 14.948 & 14.866 & 16.398 & 21.648 & 18.030 & 12.646 & 12.412 \\
\hline & Máximo & 19.303 & 17.776 & 25.101 & 27.778 & 25.549 & 17.711 & 14.055 \\
\hline & $3^{\circ} \mathrm{Q}$ & 17.050 & 17.208 & 18.870 & 25.311 & 23.036 & 13.211 & 12.619 \\
\hline & Desv.padrão & 3.188 & 3193 & 4.486 & 4.505 & 4.660 & 2.270 & 1.017 \\
\hline \multirow{7}{*}{$\begin{array}{l}\text { Volume de lodo } \\
\text { desaguado } \mathrm{m}^{3}\end{array}$} & $1^{\circ} \mathrm{Q}$ & 1.619 & 1.540 & 1.499 & 1.815 & 1844 & 1.669 & 1.906 \\
\hline & Mínimo & 1.164 & 916 & 1.015 & 1.248 & 1209 & 1.144 & 1.325 \\
\hline & Mediana & 1.676 & 1.766 & 1660 & 1.966 & 1912 & 1.895 & 2.178 \\
\hline & Média & 1.659 & 1.658 & 1.661 & 1.953 & 1899 & 1.896 & 2.093 \\
\hline & Máximo & 1.906 & 2.007 & 2.204 & 2.419 & 2320 & 2.597 & 2.566 \\
\hline & $3^{\circ} \mathrm{Q}$ & 1.841 & 1.927 & 1.916 & 2.129 & 2144 & 2.128 & 2.312 \\
\hline & Desv.padrão & 228 & 357 & 386 & 340 & 392 & 404 & 344 \\
\hline \multirow{7}{*}{$\begin{array}{l}\text { Captura de } \\
\text { Sólidos \% }\end{array}$} & $1^{\circ} \mathrm{Q}$ & 93 & 92 & 95 & 94 & 89 & 87 & 90 \\
\hline & Mínimo & 90 & 88 & 93 & 91 & 84 & 78 & 88 \\
\hline & Mediana & 93 & 93 & 96 & 95 & 91 & 90 & 93 \\
\hline & Média & 93 & 92 & 96 & 95 & 90 & 89 & 93 \\
\hline & Máximo & 95 & 96 & 98 & 97 & 94 & 94 & 98 \\
\hline & $3^{\circ} \mathrm{Q}$ & 94 & 93 & 97 & 96 & 91 & 91 & 96 \\
\hline & Desv.padrão & 1,4 & 2,2 & 1,7 & 1,6 & 2,9 & 4,4 & 3,7 \\
\hline \multirow{7}{*}{$\begin{array}{c}\text { Teor de Sólidos } \\
\text { no lodo } \\
\text { desaguado \% }\end{array}$} & $1^{\circ} \mathrm{Q}$ & 14,5 & 14,0 & 15,1 & 14,3 & 13,6 & 12,8 & 11,3 \\
\hline & Mínimo & 15,4 & 15,1 & 15,4 & 15,0 & 14,9 & 14,9 & 13,3 \\
\hline & Mediana & 13,8 & 13,4 & 14,5 & 13,9 & 12,9 & 12,4 & 11,2 \\
\hline & Média & 13,8 & 13,6 & 14,3 & 14,0 & 13,1 & 12,7 & 11,1 \\
\hline & Máximo & 12,5 & 12,5 & 12,8 & 13,3 & 12,2 & 11,7 & 9,5 \\
\hline & $3^{\circ} \mathrm{Q}$ & 13,1 & 12,9 & 13,6 & 13,5 & 12,4 & 12,2 & 10,6 \\
\hline & Desv.padrão & 0,9 & 0,9 & 1,0 & 0,6 & 0,9 & 1,0 & 0,9 \\
\hline \multirow{7}{*}{$\begin{array}{c}\text { Consumo de } \\
\text { polieletrólito } \\
\text { Kg/ton. lodo } \\
\text { desidratado }\end{array}$} & $1^{\circ} \mathrm{Q}$ & 4,36 & 4,48 & 5,11 & 5,47 & 8,42 & 7,93 & 8,56 \\
\hline & Mínimo & 3,58 & 3,90 & 4,51 & 4,60 & 7,72 & 6,07 & 8,12 \\
\hline & Mediana & 5,25 & 5,08 & 5,36 & 5,78 & 9,09 & 8,46 & 9,93 \\
\hline & Média & 5,16 & 5,15 & 5,58 & 5,85 & 8,94 & 8,38 & 9,59 \\
\hline & Máximo & 6,66 & 7,09 & 6,59 & 7,00 & 10,20 & 10,05 & 11,19 \\
\hline & $3^{\circ} \mathrm{Q}$ & 5,92 & 5,78 & 6,16 & 6,17 & 9,54 & 8,82 & 10,41 \\
\hline & Desv.padrão & 1,1 & 1,0 & 0,6 & 0,7 & 0,8 & 1,0 & 1,1 \\
\hline
\end{tabular}




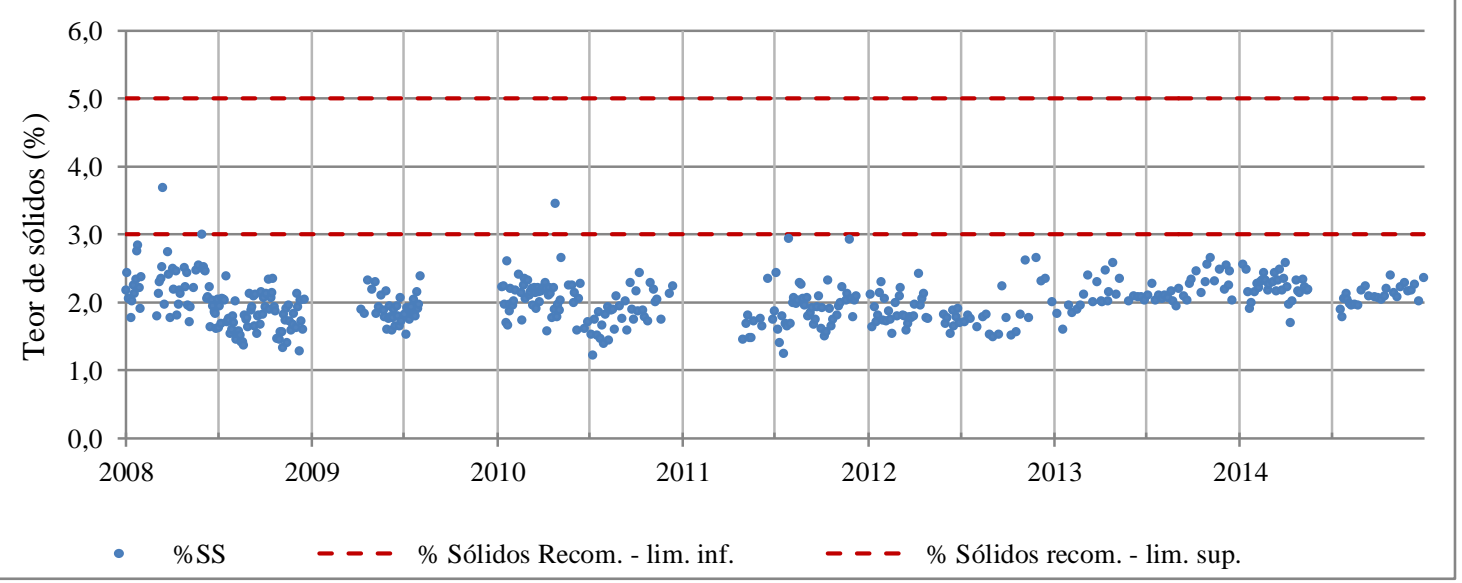

Figura 5.53 - Série temporal do teor de sólidos (\%) no lodo afluente à desidratação mecânica da ETEB Norte

Os dados levantados, no período de 2008 a 2014, apresentaram algumas lacunas no que se refere ao teor de sólidos afluentes à desidratação mecânica, nos meses de janeiro a março e setembro a dezembro de 2009 e janeiro a março de 2011.

A Figura 5.53 mostra a distribuição da concentração de sólidos no lodo afluente à desidratação mecânica, ao longo dos anos monitorados. Por ela se observa que o teor de sólidos esteve sempre abaixo ao reportado pela literatura, que varia entre 3 a $5 \%$ (Gonçalves et al.,2001), sendo que os valores médios verificados variaram de 1,87 a $2,18 \%$.

Turovskiy e Mathai (2006) apresentam como uma das vantagens das prensas desaguadoras o fato de desaguar lodos com concentrações variadas de sólidos, sendo possível admitir concentração de $1 \%$ de sólidos. Com isso, apesar de o teor de sólidos afluentes às prensas estar abaixo do recomendado para o lodo digerido (3 a 5\% ST), o desempenho é satisfatório quanto ao requisito do equipamento, pois as médias se mantiveram acima de $1 \% \mathrm{ST}$.

A carga hidráulica aplicada ao equipamento é um parâmetro de avaliação de seu desempenho. Segundo Gonçalves et al. (2001), para prensas desaguadoras desidratando lodo anaeróbio, a carga hidráulica esperada varia entre 6,4 a $15 \mathrm{~m}^{3} / \mathrm{h}$. As Figuras 5.54 e Figura 5.55 mostram a variabilidade das cargas aplicadas e dos volumes de lodo afluente à desidratação mecânica da ETEB Norte, no período monitorado. 


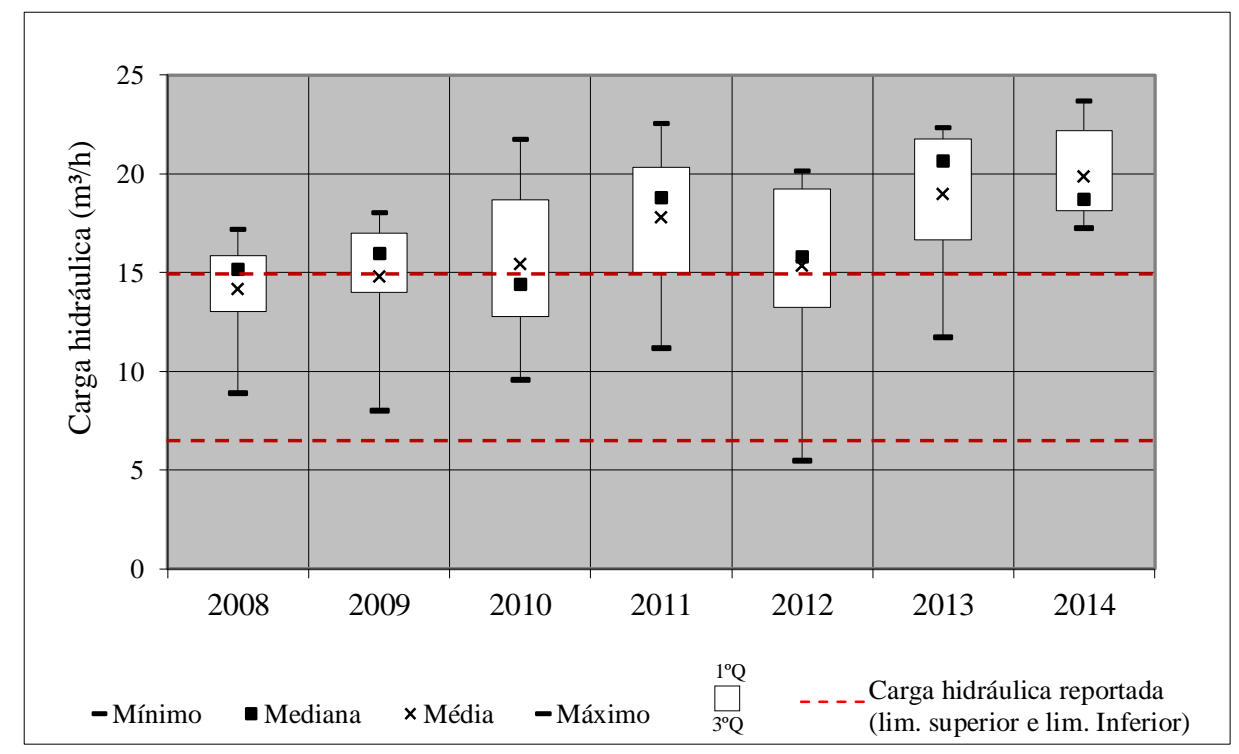

Figura 5.54 - Box-plot da carga hidráulica média diária aplicada às prensas desaguadoras da ETEB Norte

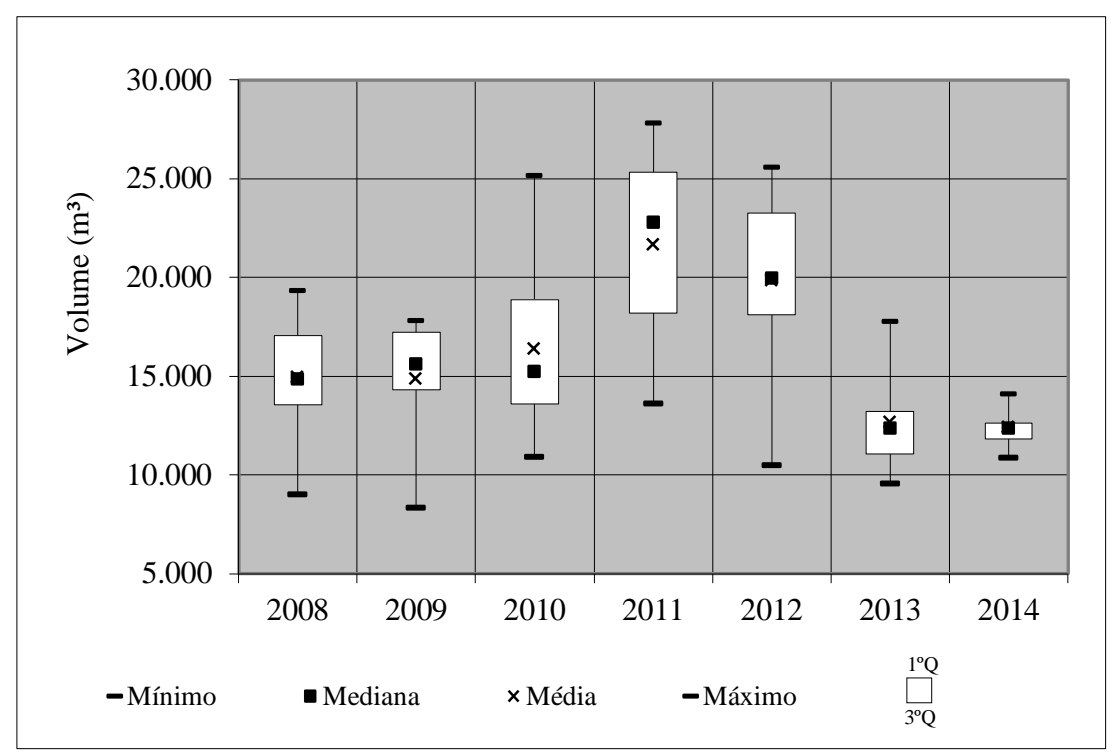

Figura 5.55 - Box-plot do volume médio diário de lodo afluente à desidratação mecânica da ETEB Norte

Nota-se pela Figura 5.54, em que a linha tracejada em vermelho indica os valores reportados pela literatura, que a carga média aplicada ao equipamento foi superior à faixa típica, denotando boa produtividade das prensas desaguadoras na ETEB Norte, com valores médios variando de: 14,14 (2008); 14,79 (2009); 15,44 (2010); 17,79 (2011); 15,34 (2012); 18,98 (2013) e 19,87 (2014). Verifica-se uma evolução dessa produtividade ao longo do tempo, associada, segundo relatos dos operadores do sistema, à melhorias 
operacionais na unidade, no tocante à instalação de inversores de frequência nas bombas, aumento da capacidade das bombas de recalque de lodo e de dosagem de polímero.

Na Figura 5.55 é possível identificar três períodos distintos quanto ao volume de lodo afluente à unidade de desidratação, o primeiro (2008 a 2009) em que os volumes afluentes variaram de 14.948 a $14.866 \mathrm{~m}^{3}$, o segundo (2010 a 2012) com valores entre 16.398 a $21.648 \mathrm{~m}^{3}$ e o terceiro (2013 a 2014) com volumes de 12.646 a $12.412 \mathrm{~m}^{3}$. Entre as possíveis causas para explicar essas alterações estão um aumento da parcela de lodo químico nos anos de 2010 a 2012, mostrando a importância do controle operacional dessa unidade, além de mudanças operacionais introduzidas a partir do final de 2012, como a colocação em carga de um terceiro reator biológico, oferecendo mais flexibilidade ao processo biológico para assimilação de cargas afluentes à estação, e otimização da operação no polimento final (mencionada no item 5.2.2.4), entre outros.

A eficiência na captura de sólidos no processo de desaguamento do lodo da ETEB Norte e o teor de sólidos no lodo desaguado são mostrados nas Figuras 5.56 e 5.57 a seguir.

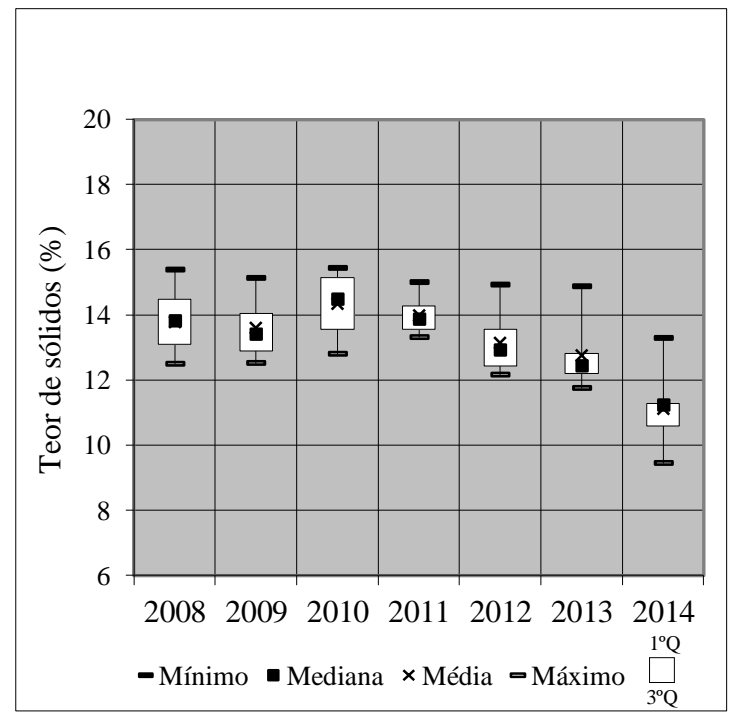

Figura 5.56 - Box-plot do teor de sólidos no lodo desaguado da ETEB Norte

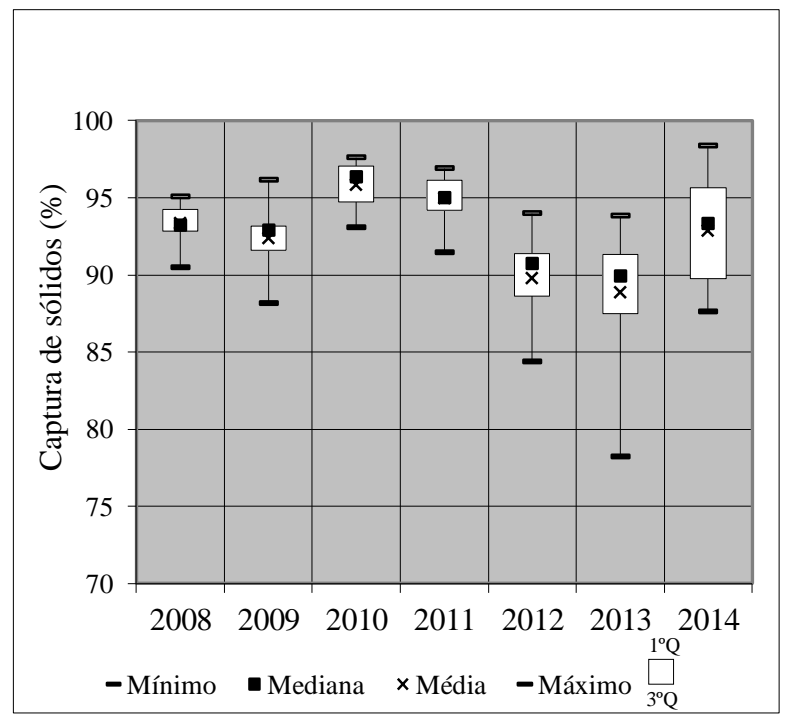

Figura 5.57 - Box-plot da captura de sólidos no lodo desaguado da ETEB Norte

Conforme observado pela Figura 5.56 o lodo desaguado apresenta teor de sólidos médio entre 11,1 a 14,3\%, com queda gradativa do teor de sólidos, percebida a partir de 2012. Essa redução no desempenho da remoção de umidade no lodo acompanhou a redução na eficiência de sólidos voláteis no lodo digerido, mencionada no item 5.2.2.5, que saiu de 
48\% (2011) para 45\%(2012), 43\% (2013) e 39\%(2014). Isso corrobora a afirmação de Miki (1998) de que, a digestão anaeróbia de lodo deficiente, piora a capacidade de desidratação, uma vez que a digestão anaeróbia interfere no tamanho das partículas, um dos fatores preponderantes no desempenho do condicionamento do lodo e, por conseguinte, da remoção de umidade.

Os resultados de teor de sólidos no lodo desaguado também apresentam valores abaixo da faixa típica reportada pela literatura, que admite valores de 15 a 25\% (Gonçalves et al.,2001; Jordão e Pessoa, 2005).

Nota-se pela Figura 5.57 que os valores médios de captura de sólidos variaram de: 93\% (2008); 92\% (2009); 96\% (2010); 95\% (2011); 90\% (2012); 89\% (2013) e 93\% (2014), quando a captura esperada para prensas desaguadoras está entre 85 e 98\% (Gonçalves et al.,2001; Jordão e Pessoa, 2005). Dessa forma, verifica-se que para o parâmetro captura de sólidos, o desaguamento do lodo na ETEB Norte encontra-se com desempenho satisfatório.

O consumo de polímero catiônico para condicionamento do lodo, ao longo dos anos monitorados, é apresentado na Figura 5.58 a seguir.

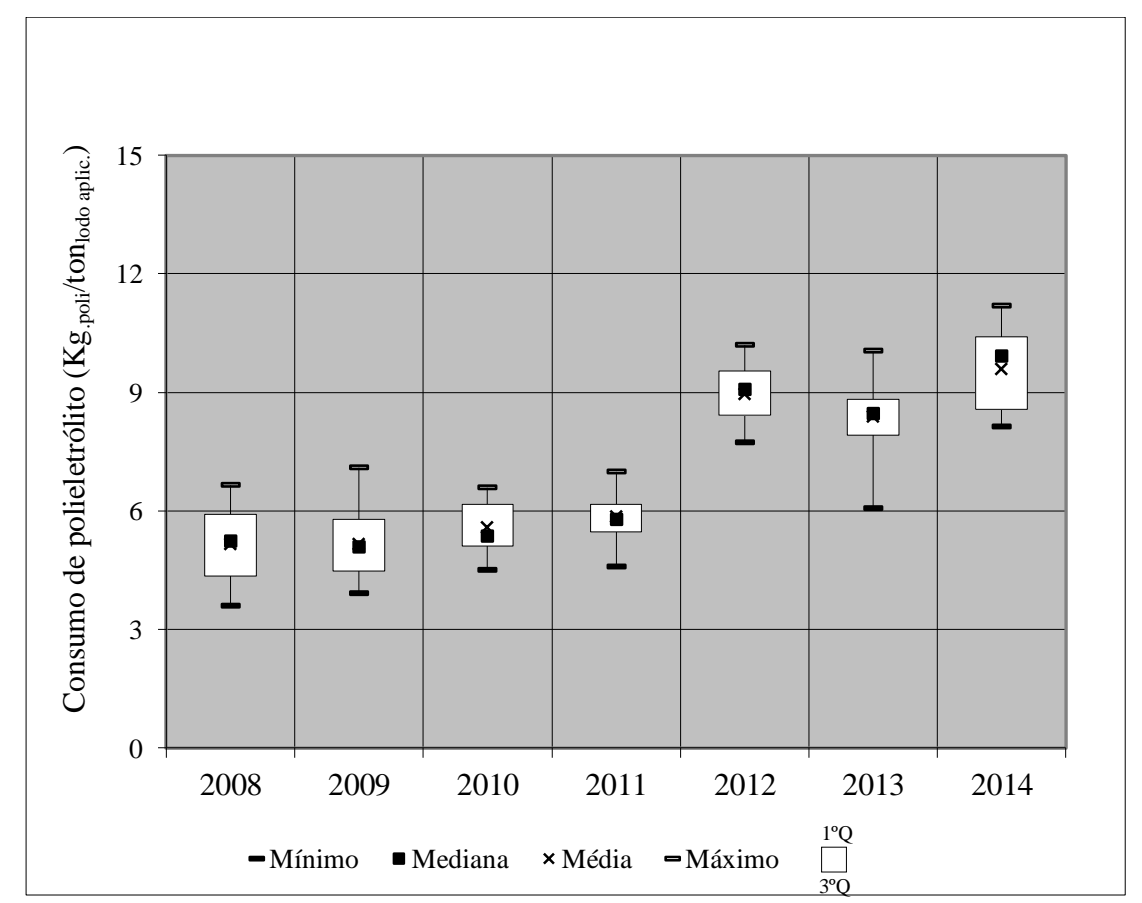

Figura 5.58 - Box-plot do consumo de polímero catiônico no condicionamento do lodo afluente à desidratação da ETEB Norte 
Jordão e Pessoa (2005) relatam que a faixa típica para consumo de polímero no condicionamento do lodo é de 4 a $6 \mathrm{Kg} /$ ton de massa seca. A Figura 5.56 apresenta valores médios de 5,78 a $6,17 \mathrm{Kg} /$ ton massa seca, entre os anos de 2008 e 2011 e de 8,82 e 10,41 Kg/ton massa seca, entre 2012 e 2014. Isso indica um aumento expressivo de consumo de polímeros a partir de 2012.

Segundo Miki (1998), o aumento no teor de sólidos no lodo a ser condicionado diminui o consumo de polímero, em base seca, como verificado anteriormente as concentrações de sólidos no lodo afluente à desidratação não atinge a faixa típica, o que demonstra a necessidade de otimização de processos como adensamento e digestão de maneira a aumentar a concentração e reduzir o consumo de produto químico.

\subsection{ANÁliSE DO PADRÃo DE PRODUÇÃO DE LODOS DE ESGOTOS NAS ETES DO DF}

O Distrito Federal destaca-se, em âmbito nacional, no que diz respeito aos indicadores de saneamento, principalmente em relação ao índice de atendimento com coleta de esgotos e ao percentual de esgotos coletados tratados. Essa condição, entretanto, também o eleva à posição de maior produtor de lodo per capita do país. Aliado a isso, no Distrito Federal são também empregadas variadas tecnologias de tratamento de esgotos, combinando diferentes processos, que torna a estimativa de produção de lodo um problema de maior complexidade.

A produção de lodos ao longo do processo de tratamento de esgotos está submetida a influência de diversas variáveis: vazão de esgotos e carga orgânica afluentes, tecnologias de tratamento de esgotos empregadas, eficiência operacional, processos de tratamento de lodo adotados, desempenho das estações de tratamento de esgotos e das unidades de tratamento de lodo, entre outros. Os volumes de lodo a serem dispostos, assim como as características qualitativas, impactam sobremaneira o planejamento da gestão dos resíduos de uma ETE. Por essa razão, o conhecimento dos padrões de produção de lodo, nas diferentes etapas de geração e para as condições das ETEs do Distrito Federal, é essencial para elaboração das projeções dos volumes de lodos gerados. 
Como comentado no item 5.1.2, não existe, na maioria das ETEs do DF, um controle sistematizado da produção de lodo ao longo das fases intermediárias, quer sejam de geração ou de tratamento dos diferentes tipos de lodos. O levantamento realizado demonstrou também que as rotinas de descartes de lodo não seguem um padrão, e são estabelecidas de acordo com a experiência operacional, de forma empírica, ou com a disponibilidade das unidades de tratamento de lodo subsequentes. Essa prática operacional dificulta a identificação de coeficientes de produção de lodo, necessários para a elaboração de estudos que visem a melhorias de desempenho das unidades ou à seleção de alternativas de disposição final do lodo.

Nesse contexto, foi realizada uma avaliação da produção teórica de lodos, utilizando coeficientes obtidos da literatura especializada, para a condição atual caracterizada no Distrito Federal. Os valores determinados teoricamente foram, posteriormente, comparados aos dados de operação levantados no estudo de caso. Com isso, foi possível identificar se os coeficientes reportados pela literatura clássica são aplicáveis às condições do Distrito Federal e podem ser utilizados com segurança na construção de cenários futuros de manejo de lodo.

\subsubsection{Produção teórica de lodo nas ETEs do Distrito Federal}

Os processos de tratamento no Distrito Federal caracterizam-se por uma composição de diversas tecnologias, dessa forma, para a determinação da produção teórica de lodo, foram considerados os parâmetros apresentados nas Tabelas 5.27 e 5.28 (Alem Sobrinho, 2001; Jordão e Pessoa, 2005):

Tabela 5.27 - Parâmetros adotados para cálculo de produção teórica de lodo: remoção, coeficiente de produção e teor de sólidos.

\begin{tabular}{|c|c|c|c|c|c|}
\hline \multirow{2}{*}{$\begin{array}{c}\text { Processo de tratamento } \\
\text { de esgotos }\end{array}$} & \multirow{2}{*}{$\begin{array}{l}\text { Remoções } \\
\text { esperadas }{ }^{1} \%\end{array}$} & \multicolumn{2}{|c|}{$\begin{array}{c}\text { Coeficiente de produção de } \\
\text { lodo }^{2} \mathrm{P}_{\mathrm{L}}-\text { (gSS/hab.dia) }\end{array}$} & \multicolumn{2}{|c|}{$\begin{array}{c}\text { Teor de sólidos }{ }^{3} \\
\% \mathrm{ST}\end{array}$} \\
\hline & & faixa & adotado & faixa & adotado \\
\hline Decantador Primário & 30 & 35 a 45 & 40 & 2 a 6 & 4 \\
\hline Reator UASB & 60 & 7 a 18 & 15 & 3 a 6 & 4,5 \\
\hline Lagoa anaeróbia & 60 & 13 a 45 & 30 & 15 a 20 & 17 \\
\hline Lagoa facultativa & 60 & 20 a 25 & 23 & 10 a 20 & 15 \\
\hline Lagoa maturação & 60 & 3 a 20 & 15 & 3 a 20 & 10 \\
\hline
\end{tabular}

Notas: (1) Tabela PRODES

(2) Alem Sobrinho (2001); Jordão e Pessoa (2005)

(3) von Sperling (2001) 
Tabela 5.28 - Parâmetros adotados para cálculo de produção teórica de lodo: remoção e coeficiente de produção.

\begin{tabular}{l|c|c|c}
\hline \multirow{2}{*}{ Processo de tratamento de esgotos } & \multirow{2}{*}{$\begin{array}{l}\text { Remoções } \\
\text { esperadas }\end{array}$} & \multicolumn{2}{|c}{$\begin{array}{c}\text { Coeficiente de produção } \\
\text { de } \text { lodo }^{2} \mathrm{P}_{\mathrm{L}}-(\mathrm{L} / \text { hab.dia) }\end{array}$} \\
\cline { 3 - 4 } & $\%$ & faixa & adotado $^{3}$ \\
\hline \hline Lodo ativado convencional & 90 & $3,1-8,2$ & 8,2 \\
\hline Lodo ativado aeração prolongada & 90 & $3,3-5,6$ & 5,6 \\
\hline
\end{tabular}

Notas: (1) Tabela PRODES - ANA

(2) von Sperling (2002)

(3) no caso de lodos ativados, por conservadorismo, foram adotados os limites superiores da faixa apresentada na literatura, visto que os reatores biológicos adotados na CAESB apresentam algumas peculiaridades.

Os volumes de lodo foram calculados a partir das equações apresentadas no item 4.4 e são apresentados na Tabela 5.29. Na Tabela 5.30 são ilustrados os mesmos cálculos, entretanto, considerando a população equivalente, obtida em função da carga orgânica medida em 2013.

Tabela 5.29 - Produção teórica de lodo nas ETEs do Distrito Federal considerando a carga orgânica teórica

\begin{tabular}{|c|c|c|c|c|c|c|}
\hline \multirow{2}{*}{$\begin{array}{c}\text { ESTAÇÕES DE } \\
\text { TRATAMENTO DE } \\
\text { ESGOTOS DO DF }\end{array}$} & \multirow{2}{*}{$\begin{array}{c}\text { População } \\
\text { Atendida } \\
\text { no hab }^{\circ}\end{array}$} & \multirow{2}{*}{$\begin{array}{l}\text { Carga Teórica } \\
\text { (kg DBO/dia) }\end{array}$} & \multicolumn{4}{|c|}{ Produção teórica de lodos $\left(\mathbf{m}^{3}\right)$} \\
\hline & & & $\begin{array}{c}\text { Lodo } \\
\text { Primário }^{1}\end{array}$ & $\begin{array}{c}\text { Lodo } \\
\text { anaeróbio }^{2}\end{array}$ & $\begin{array}{c}\text { Lodo } \\
\text { Lagoas }\end{array}$ & $\begin{array}{c}\text { Lodo } \\
\text { aeróbio }^{3}\end{array}$ \\
\hline ETE BRASÍLIA SUL & 487.628 & 26.332 & 488 & - & - & 2.799 \\
\hline ETE BRASÍLIA NORTE & 163.494 & 8.829 & 163 & - & - & 938 \\
\hline ETE RIACHO FUNDO & 34.055 & 1.839 & - & - & - & 279 \\
\hline ETE TORTO & 1.226 & 66 & - & - & - & - \\
\hline ETE SOBRADINHO & 83.699 & 4.520 & 130 & - & - & 284 \\
\hline ETE PLANALTINA & 114.437 & 6.180 & - & 38 & 7 & - \\
\hline ETE V. AMANHECER & 19.834 & 1.071 & - & 7 & 1 & - \\
\hline ETE PARANOÁ & 96.215 & 5.196 & - & 32 & 6 & - \\
\hline ETE S.SEBASTIÃO & 75.817 & 4.094 & - & 25 & 5 & - \\
\hline ETE GAMA & 121.509 & 6.561 & - & 41 & 0 & 272 \\
\hline ETE S. MARIA & 41.771 & 2.256 & - & 14 & 3 & - \\
\hline ETE ALGADO & 77.673 & 4.194 & - & 26 & 5 & - \\
\hline ETE REC. EMAS & 160.978 & 8.693 & - & 54 & 10 & - \\
\hline ETE SAMAMBAIA & 191.818 & 10.358 & - & 64 & 12 & - \\
\hline ETE MELCHIOR & 577.031 & 31.160 & - & 192 & - & 1.293 \\
\hline ETE BRAZLÂNDIA & 44.629 & 2.410 & - & - & 11 & - \\
\hline
\end{tabular}

Notas:

(1) Lodo primário bruto proveniente do Decantador primário

(2) Lodo anaeróbio proveniente do descarte dos reatores UASB

(3) Lodo aeróbio proveniente do descarte de lodo excedente dos reatores biológicos (lodos ativados) 
Tabela 5.30 - Produção teórica de lodo nas ETEs do Distrito Federal considerando a carga orgânica real aplicada em 2013

\begin{tabular}{|c|c|c|c|c|c|c|}
\hline \multirow[b]{2}{*}{$\begin{array}{c}\text { ESTAÇÕES DE } \\
\text { TRATAMENTO DE } \\
\text { ESGOTOS DO DF }\end{array}$} & \multirow[b]{2}{*}{$\begin{array}{c}\text { População } \\
\text { Equivalent } \\
\text { e n⿳⺈ hab }\end{array}$} & \multirow[b]{2}{*}{$\begin{array}{l}\text { Carga real (2013) } \\
\quad \text { (kg DBO/dia) }\end{array}$} & \multicolumn{4}{|c|}{ Produção teórica de lodos $\left(\mathrm{m}^{3} / \mathrm{d}\right)$} \\
\hline & & & $\begin{array}{c}\text { Lodo } \\
\text { Primário } \\
1\end{array}$ & $\begin{array}{c}\text { Lodo } \\
\text { anaeróbio } \\
2\end{array}$ & $\begin{array}{c}\text { Lodo } \\
\text { Lagoa } \\
\text { S } \\
\end{array}$ & $\begin{array}{c}\text { Lodo } \\
\text { aeróbio }^{3}\end{array}$ \\
\hline ETE BRASÍLIA SUL & 597.040 & 32.240 & 597 & - & - & 3.427 \\
\hline ETE BRASÍLIA NORTE & 241.523 & 13.042 & 242 & - & - & 1.386 \\
\hline ETE RIACHO FUNDO & 39.910 & 2.155 & - & - & - & 327 \\
\hline ETE TORTO & 2.198 & 119 & - & - & - & - \\
\hline ETE SOBRADINHO & 69.670 & 3.762 & 108 & - & - & 236 \\
\hline ETE PLANALTINA & 101.617 & 5.487 & - & 34 & 6 & - \\
\hline ETE V. AMANHECER & 15.096 & 815 & - & 5 & 1 & - \\
\hline ETE PARANOÁ & 77.219 & 4.170 & - & 26 & 5 & - \\
\hline ETE S.SEBASTIÃO & 108.598 & 5.864 & - & 36 & 7 & - \\
\hline ETE GAMA & 113.943 & 6.153 & - & 38 & 0 & 255 \\
\hline ETE S. MARIA & 54.835 & 2.961 & - & 18 & 3 & - \\
\hline ETE ALGADO & 98.150 & 5.300 & - & 33 & 6 & - \\
\hline ETE REC. EMAS & 155.081 & 8.374 & - & 52 & 10 & - \\
\hline ETE SAMAMBAIA & 330.030 & 17.822 & - & 110 & 20 & - \\
\hline ETE MELCHIOR & 465.718 & 25.149 & - & 155 & 0 & 1.043 \\
\hline ETE BRAZLÂNDIA & 46.334 & 2.502 & - & 0 & 11 & - \\
\hline
\end{tabular}

\subsubsection{Produção real de lodo na ETE Brasília Norte}

Para validação dos coeficientes de produção de lodo, foram utilizados os dados de volume e concentração de sólidos levantados no estudo de caso, para cada uma das etapas de tratamento da fase sólida, referente ao ano de 2013. Dessa forma, pode-se compará-lo com a produção teórica calculada. Esses dados são apresentados nas Tabelas 5.31 e 5.32 a seguir. 
Tabela 5.31 - Volume médio diário de lodos produzidos diariamente na ETEB Norte, nas diferentes etapas de geração e tratamento

\begin{tabular}{l|c|c|c|c|c|c|c|c}
\hline \multicolumn{1}{c|}{ Mês } & $\begin{array}{c}\text { Vazão de } \\
\text { esgotos } \\
\text { afluente }\end{array}$ & $\begin{array}{c}\text { Lodo } \\
\text { primá- } \\
\text { rio }\end{array}$ & $\begin{array}{c}\text { Lodo } \\
\text { primá- } \\
\text { rio } \\
\text { adensa- } \\
\text { do }\end{array}$ & $\begin{array}{c}\text { Lodo } \\
\text { aeróbio }\end{array}$ & $\begin{array}{c}\text { Lodo } \\
\text { aeróbio } \\
\text { Adensa- } \\
\text { do }\end{array}$ & $\begin{array}{c}\text { Lodo } \\
\text { químico }\end{array}$ & $\begin{array}{c}\text { Lodo digerido } \\
\text { Lpad+ } \\
\text { Lad+Lq) }\end{array}$ & Torta \\
\hline \hline Janeiro & 44.133 & 1.776 & 67 & 992 & - & 225 & 291 & 52 \\
\hline Fevereiro & 43.617 & 1.242 & 72 & 1.414 & 155 & 203 & 430 & 53 \\
\hline Março & 44.353 & 1.443 & 77 & 1.155 & 154 & 242 & 473 & 60 \\
\hline Abril & 42.904 & 1.386 & 78 & 1.334 & 214 & 157 & 449 & 56 \\
\hline Maio ${ }^{1}$ & 41.213 & 957 & 44 & 800 & 103 & 143 & 290 & 37 \\
\hline Junho & 37.581 & 1.511 & 84 & 1.462 & 135 & 219 & 438 & 64 \\
\hline Julho & 37.554 & 1.414 & 103 & 1.088 & 132 & 338 & 574 & 84 \\
\hline Agosto & 37.700 & 1.022 & 94 & 1.032 & 185 & 138 & 417 & 55 \\
\hline Setembro & 39.913 & 1.031 & 95 & 1.256 & 175 & 166 & 436 & 68 \\
\hline Outubro & 40.473 & 1.398 & 97 & 1.157 & 176 & 98 & 371 & 68 \\
\hline Novembro & 42.010 & 1.398 & 92 & 1.299 & 178 & 114 & 384 & 72 \\
\hline Dezembro & 42.803 & 1.201 & 88 & 1.323 & 186 & 117 & 391 & 78 \\
\hline
\end{tabular}

Legenda: Lpad - lodo primário adensado; Lad - lodo aeróbio adensado; Lq - lodo químico; Torta: lodo desaguado

Nota: (1) No mês de maio houve greve de funcionários da CAESB e os dados estavam incompletos, com pouca representatividade.

Tabela 5.32 - Média diária do Teor de sólidos em suspensão dos diferentes tipos de lodos produzidos diariamente na ETEB Norte, em \%, ano 2013.

\begin{tabular}{l|c|c|c|c|c|c|c}
\hline \multicolumn{1}{c|}{ Mês } & $\begin{array}{c}\text { Lodo } \\
\text { primário }\end{array}$ & $\begin{array}{c}\text { Lodo } \\
\text { primario } \\
\text { adens. }\end{array}$ & $\begin{array}{c}\text { Lodo } \\
\text { aeróbio }\end{array}$ & $\begin{array}{c}\text { Lodo aer. } \\
\text { Adens. }\end{array}$ & $\begin{array}{c}\text { Lodo } \\
\text { químico }\end{array}$ & $\begin{array}{c}\text { Lodo } \\
\text { digerido }\end{array}$ & Torta \\
\hline \hline Janeiro & 0,78 & 4,13 & 0,46 & 3,95 & 1,43 & 1,8 & 14 \\
\hline Fevereiro & 0,88 & 4,43 & 0,49 & 4,05 & 1,60 & 1,9 & 15 \\
\hline Março & 1,01 & 4,96 & 0,43 & 3,99 & 2,17 & 2,2 & 12 \\
\hline Abril & 0,65 & 3,76 & 0,44 & 4,09 & 2,48 & 2,3 & 12 \\
\hline Maio & 0,77 & 3,45 & 0,41 & 3,77 & 2,29 & 2,2 & 12 \\
\hline Junho & 0,67 & 2,95 & 0,44 & 3,87 & 2,29 & 2,2 & 12 \\
\hline Julho & 0,78 & 3,62 & 0,45 & 3,91 & 1,67 & 2,1 & 12 \\
\hline Agosto & 0,54 & 4,20 & 0,44 & 3,75 & 1,60 & 2,1 & 12 \\
\hline Setembro & 0,57 & 4,62 & 0,48 & 3,89 & 1,81 & 2,1 & 13 \\
\hline Outubro & 0,67 & 4,35 & 0,49 & 4,28 & 2,01 & 2,4 & 13 \\
\hline Novembro & 1,33 & 4,08 & 0,49 & 4,46 & 1,88 & 2,5 & 13 \\
\hline Dezembro & 0,56 & 4,18 & 0,49 & 4,16 & 2,18 & 2,2 & 13 \\
\hline
\end{tabular}

Nota: (1) No mês de maio houve greve de funcionários da CAESB e os dados estavam incompletos, com pouca representatividade.

Como pode ser observado pela Tabela 5.31, o volume de lodo primário produzido na ETEB Norte variou de 1.022 a $1.776 \mathrm{~m}$ 3/d, em 2013, esse volume é muitas vezes superior 
ao volume estimado utilizando os coeficientes da literatura, para ambas situações calculadas (Tabelas 5.29 e 5.30) que foram de 163 e $242 \mathrm{~m}^{3} / \mathrm{d}$, respectivamente. Algumas das causas para essa diferença foram comentadas no item 5.2.2.1, por ocasião da avaliação de desempenho do decantador primário, quais sejam: regime de extração de lodo baseado em experiência operacional (empirismo) ou nas condições operacionais do adensador por gravidade, teor de sólidos no lodo primário abaixo do reportado na literatura, em consequência da frequência elevada de retirada do lodo.

Os dados de projeto da ETEB Norte previam que, para a vazão média de esgotos afluentes (920L/s), o volume estimado de lodo extraído do decantador primário seria de 475,2 $\mathrm{m}^{3} /$ dia, com uma concentração de $2 \%$. Segundo relatos dos operadores do sistema, desde o início de operação da estação, esses valores nunca foram atendidos.

Para obtenção do coeficiente de produção de lodo primário, segundo as condições reais de operação da ETEB Norte, foram utilizados além dos dados acima, as concentrações de DBO afluente e a população equivalente, determinada a partir da Equação 5.2. Os dados são apresentados na Tabela 5.33 a seguir.

Tabela 5.33 - Parâmetros operacionais da ETEB Norte e valores de população equivalente e coeficiente de produção de lodos determinados a partir das equações, dados de 2013

\begin{tabular}{|c|c|c|c|c|}
\hline Mês & $\begin{array}{c}\text { Conc. média } \\
\text { de DBO } \\
\text { afluente } \\
(\mathrm{mg} / \mathrm{L})\end{array}$ & $\begin{array}{c}\text { População } \\
\text { equivalente }(\text { hab }) \\
P e=\frac{C O_{\text {aplicada }} \times 1000}{C c}\end{array}$ & $\begin{array}{l}\text { Conc. média } \\
\text { de SS no lodo } \\
\text { primário } \\
(\%)\end{array}$ & $\begin{array}{c}\begin{array}{c}\text { Coeficiente de produção de lodo } \\
\text { primário }-\mathrm{P}_{\mathrm{L}} \\
(\mathrm{gSS} / \text { hab.dia })\end{array} \\
V_{\text {Lodo }}=\frac{\left(P e \times P_{L}\right) \div 1000}{T s \times 10}\end{array}$ \\
\hline Janeiro & 270,0 & 220.665 & 0,78 & 63 \\
\hline Fevereiro & 257,5 & 207.990 & 0,88 & 52 \\
\hline Março & 200,0 & 164.270 & 1,01 & 89 \\
\hline Abril & 350 & 278.081 & 0,65 & 32 \\
\hline Maio & 372,5 & 284.294 & 0,77 & 26 \\
\hline Junho & 285 & 198.344 & 0,67 & 51 \\
\hline Julho & 405,0 & 281.657 & 0,78 & 39 \\
\hline Agosto & 332 & 231.785 & 0,54 & 24 \\
\hline Setembro & 313,3 & 231.567 & 0,57 & 25 \\
\hline Outubro & 250 & 187.373 & 0,67 & 50 \\
\hline Novembro & 460,0 & 357.861 & 1,33 & 52 \\
\hline Dezembro & 253,3 & 200.778 & 0,56 & 34 \\
\hline
\end{tabular}

Nota: (1)No mês de maio houve greve de funcionários da CAESB e os dados estavam incompletos, com pouca representatividade. 
A literatura especializada apresenta um coeficiente de produção de lodo primário entre 35 a $45 \mathrm{gSS} /$ hab.dia, com teor de sólidos variando de 2 a 6\%. O lodo primário na ETEB Norte apresentou coeficientes de produção de 24 a 89 gSS/hab.dia, com concentração de sólidos entre 0,54 a 1,33 \%SS. Entre as conclusões que podem ser extraídas a partir dessa análise, tem-se que as características do lodo primário, quantitativas e qualitativas, atualmente, são fortemente dependentes das condições operacionais da ETE, mostrando uma variabilidade acentuada dos coeficientes de produção de lodo calculados. Outra constatação relevante é que essa etapa do tratamento nunca foi operada conforme os parâmetros de projeto, gerando volumes de lodo significativamente superiores, sendo, portanto, recomendado o estudo da otimização da operação de extração de lodo do decantador primário, para obtenção de uma menor produção de lodo, com concentrações mais elevadas.

Os mesmos cálculos foram feitos para se determinar a produção de lodo aeróbio não estabilizado (lodo excedente do reator biológico de lodos ativados). A eficiência média de remoção de DBO admitida no tratamento primário foi de $22 \%$, menor que a eficiência reportada na literatura e a indicada em projeto, tendo em vista os reciclos internos de líquido clarificado dos adensadores (gravidade e flotação), que contribuem com carga de DBO e SS à montante dos decantadores primários. Os dados são apresentados na Tabela 5.34 .

Os volumes de lodo aeróbio não estabilizado variaram de 992 a $1.462 \mathrm{~m} 3 / \mathrm{d}$, enquanto os volumes determinados foram de 938 e 1.386 m³/d, para carga orgânica teórica e carga orgânica real aplicada aos reatores, respectivamente. O coeficiente de produção de lodo $\left(\mathrm{P}_{\mathrm{L}}\right)$ para o lodo aeróbio - processo de lodos ativados - apresentado pela literatura está entre 3,1 a 8,2 L/hab.dia, os valores determinados em função da produção real de lodo variaram de 3,6 a 9,5 L/hab.dia, uma diferença de $14 \%$ maior para a produção real. Isso demonstra maior estabilidade operacional dessa etapa do processo de tratamento de esgotos, o que confere maior segurança na elaboração de projeções de produção de lodo para essa etapa do tratamento. 
Tabela 5.34 - Parâmetros operacionais e valores determinados de população equivalente e coeficiente de produção de lodo para os reatores biológicos de lodos ativados da ETEB Norte, dados de 2013

\begin{tabular}{|c|c|c|c|}
\hline Mês & $\begin{array}{c}\text { DBO remanescente } \\
(\mathrm{mg} / \mathrm{L}) \\
D B O_{\text {rem }}=D B O_{\text {afluente }} \times(1-R)\end{array}$ & $\begin{array}{l}\text { População equivalente } \\
\text { (hab) } \\
P e=\frac{C O_{\text {aplicada }} \times 1000}{C c}\end{array}$ & $\begin{array}{c}\begin{array}{c}\text { Coeficiente de produção de } \\
\text { lodo primário }-\mathrm{P}_{\mathrm{L}} \\
(\mathrm{L} / \text { hab.dia })\end{array} \\
P_{L}=\frac{V_{\text {Lodo }} \times 1000}{P e}\end{array}$ \\
\hline Janeiro & 210,6 & 172.118 & 5,8 \\
\hline Fevereiro & 200,9 & 162.232 & 8,7 \\
\hline Março & 156,0 & 128.131 & 9,0 \\
\hline Abril & 273,0 & 216.903 & 6,2 \\
\hline Maio & 290,6 & 221.749 & 3,6 \\
\hline Junho & 222,3 & 154.708 & 9,5 \\
\hline Julho & 315,9 & 219.693 & 5,0 \\
\hline Agosto & 259,0 & 180.792 & 5,7 \\
\hline Setembro & 244,4 & 180.622 & 7,0 \\
\hline Outubro & 195,0 & 146.151 & 7,9 \\
\hline Novembro & 358,8 & 279.131 & 4,7 \\
\hline Dezembro & 197,6 & 156.607 & 8,4 \\
\hline
\end{tabular}

(1) No mês de maio houve greve de funcionários da CAESB e os dados estavam incompletos, com pouca representatividade.

Como no fluxo de tratamento de esgotos da ETEB Norte não há reatores anaeróbios (UASB) e essa tecnologia é empregada em 11 ETEs do Distrito Federal, foi verificado junto às ETEs que empregam essa tecnologia, quais teriam um controle do volume de lodo descartado do reator anaeróbio. Apenas a ETE Paranoá possuía o registro do volume descartado ao longo do ano de 2014.

O descarte de lodo anaeróbio na ETE Paranoá ocorre por meio do envio do lodo de fundo do reator para um poço de bombeamento e de lá o lodo é enviado para os leitos de secagem. Dessa forma, a quantificação dos volumes gerados nessa etapa foi realizada a partir do número de horas de bombeamento e da curva de vazão da bomba. Para determinação do coeficiente de produção de lodo no reator anaeróbio, foram levantados os dados de vazão afluente de esgotos e a concentração de DBO afluente, e, a partir desses dados, foi calculada a população equivalente, admitindo-se um teor de sólidos de 4,5 \% SS. Os dados são apresentados na Tabela 5.35. 
Tabela 5.35 - Parâmetros operacionais da ETE Paranoá e valores determinados de população equivalente e coeficiente de produção de lodo no reator UASB, dados de 2014

\begin{tabular}{|c|c|c|c|c|c|c|}
\hline Mês & $\begin{array}{l}\text { Vazão de } \\
\text { esgotos } \\
\text { afluentes } \\
\left(\mathrm{m}^{3} / \mathrm{d}\right)\end{array}$ & $\begin{array}{c}\text { DBO } \\
\text { afluente } \\
(\mathrm{mg} / \mathrm{L})\end{array}$ & $\begin{array}{c}\begin{array}{c}\text { População } \\
\text { equivalente }(\text { hab })\end{array} \\
P e=\frac{C O_{\text {aplicada }} \times 1000}{C c}\end{array}$ & $\begin{array}{l}\text { Teor de } \\
\text { SS }(\%)\end{array}$ & $\begin{array}{c}\text { Volume } \\
\text { de lodo } \\
\text { descartado } \\
\text { UASB } \\
\left(\mathrm{m}^{3} / \mathrm{d}\right) \\
\end{array}$ & $\begin{array}{c}\begin{array}{c}\text { Coeficiente de produção } \\
\text { de lodo primário - } \mathrm{P}_{\mathrm{L}} \\
\text { (gSS/hab.dia) }\end{array} \\
V_{\text {Lodo }}=\frac{\left(P e \times P_{L}\right) \div 1000}{T S \times 10}\end{array}$ \\
\hline Janeiro & 6.878 & 800,0 & 101.894 & 4,50 & 6 & 3 \\
\hline Fevereiro & 7.598 & 720 & 101.306 & 4,50 & 21 & 9 \\
\hline Março & 7.718 & 680,0 & 97.184 & 4,50 & 17 & 8 \\
\hline Abril & 7.443 & 670 & 92.347 & 4,50 & 12 & 6 \\
\hline Maio & 7.092 & 610,0 & 80.117 & 4,50 & 6 & 3 \\
\hline Junho $^{1}$ & & & & & 0 & \\
\hline Julho & 6.787 & 645,0 & 81.061 & 4,50 & 35 & 20 \\
\hline Agosto & 7.303 & 606,7 & 82.055 & 4,50 & 15 & 8 \\
\hline Setembro & 7.726 & 760,0 & 108.734 & 4,50 & 13 & 5 \\
\hline Outubro & 7.995 & 588 & 87.056 & 4,50 & 16 & 8 \\
\hline Novembro & 8.269 & 735,0 & 112.551 & 4,50 & 14 & 6 \\
\hline Dezembro & 8.331 & 666,7 & 102.855 & 4,50 & 11 & 5 \\
\hline
\end{tabular}

Nota: (1) No mês de junho houve greve de funcionários da CAESB e os dados estavam incompletos, com pouca representatividade.

Pela observação da Tabela 5.35, nota-se que a produção de lodo real confirma a informação levantada por ocasião do diagnóstico, em que se verificou que os descartes de lodo dos reatores anaeróbios são realizados baseando-se em empirismo, não há rotinas padronizadas. Sendo assim, podem ser observados coeficientes de produção de lodo de 3 a 20 gSS/hab.dia.

A dificuldade em se estabelecer um padrão de produção de lodo, para a fase de tratamento primário (decantador primário e reator UASB), demonstra a necessidade de estudos visando à otimização de rotinas operacionais que contribuam para a redução da geração de lodo e permitam estabelecer parâmetros de produção de lodo e a elaboração de cenários futuros para o planejamento da gestão do lodo no Distrito Federal.

Não foram disponibilizados dados de volumes removidos nas lagoas de estabilização em nenhuma das ETEs do Distrito Federal. Dessa forma, a validação ou não do coeficiente de produção de lodo para essa tecnologia de tratamento ficou prejudicada, pela impossibilidade de comparação entre produção real e teórica. 


\subsection{USOS POTENCIAIS E DISPOSIÇÃO FINAL DOS LODOS DE ESGOTOS APLICÁVEIS AO DISTRITO FEDERAL}

A identificação das alternativas, aplicáveis ao Distrito Federal, dos usos potenciais e de disposição final para os lodos gerados nas estações de tratamento de esgotos do DF, foi desenvolvida objetivando indicar um leque de soluções que abrangesse não apenas aquelas adequadas às condições predominantes, no tocante à qualidade e à quantidade dos lodos, mas também que vislumbrasse aquelas que são exigidas quando as condições verificadas extrapolam os padrões de controle do lodo.

Preferencialmente, os usos benéficos do lodo são apontados como alternativas de interesse, sobrepujando aquelas que visam apenas o descarte do resíduo.

\subsubsection{Caracterização do Distrito Federal - área, vegetação, solo e clima}

O Distrito Federal tem uma área territorial de 5.801,937 $\mathrm{Km}^{2}$, atualmente subdividida em 31 Regiões Administrativas (RA), com uma população de 2.556.149 habitantes (PDAD, 2011).

A cobertura vegetal da região do DF é caracterizada predominantemente pelo Cerrado, um bioma complexo, que comporta uma diversidade de formações florestais, savanas e campos. Na região do Planalto Central do Brasil, o Cerrado apresenta savanas mais ou menos densas com cobertura herbácea contínua e arbustiva descontínua, cuja vegetação apresenta aspecto de cascas espessas e galhos retorcidos.

O clima do Distrito Federal é característico da região de cerrados, definido como continental tropical semiúmido, com temperatura média $25^{\circ} \mathrm{C}$, chegando ao máximo de $40^{\circ} \mathrm{C}$ no verão. Possuem duas estações bem definidas, a estação seca que, normalmente, vai de abril a setembro e estação chuvosa, de outubro a março (Maia, 2006).

Segundo Souza et al. (2006), solos típicos da região de Cerrados apresentam boas propriedades físicas, entretanto, suas características químicas são inadequadas, com elevada acidez, deficiência de nutrientes e altos teores de Al trocável, necessitando correções químicas para melhorarem seu potencial de produção e capacidade resiliente. 
O mapeamento realizado pela Embrapa (1978) apresenta três classes predominantes de solos no Distrito Federal: Latossolo Vermelho, Latossolo Vermelho-amarelo e Cambissolo, juntas essas classes abrangem cerca de 85,5\% da área territorial do DF. Conforme informações da Embrapa esses solos são caracterizadas por serem profundos, muito porosos, bastante permeáveis e que, devido a um intenso processo de intemperização, formam solos álicos, fortemente ácidos e principalmente pouco férteis, cujo uso na agricltura demanda a incorporação de fertilizantes e a correção da acidez.

No Distrito Federal, 555.391 hectares são considerados área rural pelo Plano de desenvolvimento e Ordenamento Territorial do Distrito Federal (PDOT) de 2012 e destes 440.000 ha podem ser considerados terras agricultáveis, de acordo com dados do Anuário Estatístico do Distrito Federal elaborado pela Companhia de Planejamento do Distrito Federal - Codeplan (2014).

O setor agropecuário no Distrito Federal, assim como a indústria, exerce pequeno impacto no desempenho global, pois responde apena por cerca de $0,4 \%$ do PIB local (CODEPLAN, 2014). A cultura de grãos, principalmente soja, milho e feijão, e as pastagens artificiais são predominantes, seguidas da fruticultura e a horticultura, com áreas menores. Na pecuária, se destaca a criação de bovinos, seguida por suínos e equinos, extensiva a toda a região.

Vale ressaltar que a agricultura local é desenvolvida em pequenas áreas, dada a dimensão territorial do Distrito Federal, e qualquer fator que atinja as áreas de cultivo, como efeito climático, infestação de pragas ou aplicação de novas tecnologias interfere fortemente na produção das lavouras, com grande impacto no índice do setor agropecuário.

A exploração de areia, cascalho, argila, saibro, aterro e brita são responsáveis pela maior parte das áreas degradadas no Distrito Federal e muitas dessas áreas continuam sem atividades de recuperação, mesmo diante das exigências de órgãos ambientais, que determinam a apresentação de um Plano de Recuperação de Área Degradada - PRAD, para a obtenção de licença ambiental para a mineração (Bento, 2009). São 234 jazidas de bens minerais para a construção civil existentes no Distrito Federal. (Corrêa et al., 2004). 


\subsubsection{Identificação dos usos aplicáveis ao Distrito Federal e análise comparativa para atendimento aos requisitos de qualidade}

A destinação adequada do lodo é um dos principais problemas na gestão de resíduos do processo de tratamento de esgotos. Existem diversas alternativas tecnicamente aceitáveis para a disposição final do lodo, entretanto, a seleção de uma delas deve fundamentar-se na compreensão de um complexo mosaico, onde os critérios ambientais, técnicos e econômicos estejam contemplados.

A análise do conjunto desses critérios é bastante complexa e, em algumas situações, comprometida pela escassez de dados. Dessa forma, devem ser considerados alguns aspectos que definem as condições mais favoráveis para aplicação do lodo, ou seja, aquelas alternativas que, no todo ou em parte:

a) minimizem o risco de contaminação, quer seja por lixiviação, contato ou volatilização de eventuais compostos perigosos presentes;

b) minimizem a necessidade de processamento e transformação industrial do lodo;

c) minimizem as distâncias de transporte até o destino;

d) resultem em produto reciclável.

A revisão bibliográfica permitiu um levantamento das alternativas de disposição empregadas no Brasil e no mundo (Tabela 5.36), assim como dos requisitos para cada opção. Como o critério econômico não foi objeto do presente estudo, optou-se por realizar uma análise considerando todas as alternativas de destinação final potencialmente passíveis de aplicação no Distrito Federal. Dessa forma, o mapeamento incluiu mesmo aquelas alternativas cuja implantação não é vislumbrada no curto prazo.

Para tanto, os requisitos de qualidade do lodo para os usos identificados foram considerados como linhas de corte, e as características dos lodos produzidos nas ETEs do Distrito Federal, sem qualquer tratamento complementar, foram comparadas a esses requisitos, de maneira a visualizar o atendimento ou não aos padrões de qualidade estabelecidos. 
Tabela 5.36 - Alternativas de usos potenciais e disposição final levantadas na literatura

\begin{tabular}{|c|c|c|c|}
\hline Alternativa & Vantagens & Desvantagens & Discussão \\
\hline Aterro sanitário & Não necessita estabilização & $\begin{array}{l}\text { Exigência de teor de sólidos entre } 35 \text { e } 40 \% \text {, para reduzir o } \\
\text { volume do lodo e a produção de lixiviado } \\
\text { Contaminação do solo e águas subterrâneas, caso não seja } \\
\text { operado adequadamente }\end{array}$ & $\begin{array}{l}\text { Alternativa pode ser aplicada nos casos em que as } \\
\text { características dos lodos não se enquadrem nos } \\
\text { requisitos de usos benéficos do resíduo. } \\
\text { Pode ser utilizada codisposição em o aterro sanitário de } \\
\text { resíduos sólidos urbanos. }\end{array}$ \\
\hline Landfarming & $\begin{array}{l}\text { Permite a disposição de elevadas doses de } \\
\text { lodo por vários anos. } \\
\text { Não exige estabilização prévia do lodo. }\end{array}$ & $\begin{array}{l}\text { Exige grandes áreas, que devido ao aporte continuado de } \\
\text { metais pesados e compostos químicos tóxicos (orgânicos e } \\
\text { inorgânicos) inviabiliza áreas para usos futuros. } \\
\text { Operação complexa. } \\
\text { Contaminação do solo e águas subterrâneas, se não operado } \\
\text { adequadamente. }\end{array}$ & $\begin{array}{l}\text { O Distrito Federal possui área limitada, o custo de } \\
\text { implantação seria elevado. } \\
\text { Não há aproveitamento dos nutrientes do lodo. }\end{array}$ \\
\hline Incineração & $\begin{array}{l}\text { Pode ser usada como alternativa de } \\
\text { contigência. }\end{array}$ & $\begin{array}{l}\text { Apresenta elevado custo por tonelada tratada. } \\
\text { Poluição atmosférica pela emissão de dioxinas e furanos } \\
\text { entre outros, cujos efeitos negativos à saúde humana são } \\
\text { extensos e graves. } \\
\text { Requer destinação das cinzas }\end{array}$ & $\begin{array}{l}\text { A incineração é objeto de tratado internacional com o } \\
\text { objetivo de diminuir o seu emprego (Convenção } \\
\text { Estocolmo 2001) }\end{array}$ \\
\hline $\begin{array}{l}\text { Uso agrícola } \\
\text { Recuperação de } \\
\text { áreas } \\
\text { degradadas } \\
\text { Uso em } \\
\text { silvicultura }\end{array}$ & $\begin{array}{l}\text { Promove o aproveitamento de macro e } \\
\text { micronutrientes e Reduz a aplicação de } \\
\text { fertilizantes químicos. } \\
\text { Apresenta efeito residual na produção de } \\
\text { grãos, até três anos após aplicação. } \\
\text { Promove a reciclagem do fósforo. } \\
\text { Promove melhorias nas condições físicas do } \\
\text { solo. }\end{array}$ & $\begin{array}{l}\text { Pode provocar a contaminação por metais pesados e } \\
\text { compostos tóxicos, devidos às características acumulativas } \\
\text { desses elementos. } \\
\text { Risco de lixiviação do nitrato, caso não haja um controle } \\
\text { das demandas de cada planta. } \\
\text { Pode provocar a contaminação por agentes patogênicos, } \\
\text { caso sejam dispostos sem o controle adequado. }\end{array}$ & $\begin{array}{l}\text { O Distrito Federal possui solos pouco férteis, cujo uso } \\
\text { na agricltura demanda a incorporação de fertilizantes. } \\
\text { O uso do lodo pode minimizar a aplicação de } \\
\text { fertilizantes e aumentar a produtividade das culturas de } \\
\text { grãos. } \\
\text { Muitas áreas de exploração de areia, cascalho, argila e } \\
\text { outros continuam sem recuperação e o uso do lodo } \\
\text { poderia favorecer a execução dos PRADs. }\end{array}$ \\
\hline $\begin{array}{l}\text { Produção de } \\
\text { substrato } \\
\text { vegetal }\end{array}$ & $\begin{array}{l}\text { Promove o uso integrado de resíduos (lodo } \\
\text { de ETE, lodo de ETA, resíduos de poda). } \\
\text { Reduz custo com o uso de fertilizantes } \\
\text { minerais. Alta capacidade de retenção de } \\
\text { água. }\end{array}$ & $\begin{array}{l}\text { Composição variável, devido aos diferentes resíduos que } \\
\text { podem ser utilizados. } \\
\text { Necessidade de grandes quantidades de resíduos } \\
\text { estruturantes. }\end{array}$ & $\begin{array}{l}\text { O Distrito Federal possui extensa área de jardins e } \\
\text { parques, com elevada demanda de mudas para } \\
\text { manutenção dessas áreas. } \\
\text { Necessidade de dar destino adequado aos resíduos de } \\
\text { poda. }\end{array}$ \\
\hline $\begin{array}{l}\text { matéria-prima } \\
\text { na fabricação } \\
\text { de cerâmica } \\
\text { vermelha }\end{array}$ & $\begin{array}{l}\text { Alternativa de disposição para lodos cujas } \\
\text { características apresentem limitação de } \\
\text { aplicação no solo. }\end{array}$ & $\begin{array}{l}\text { Exigência de técnicas e maquinários para fabricação. } \\
\text { Risco de contaminação, no caso de manejo manual. } \\
\text { Exigência de baixo teor de matéria orgânica. } \\
\text { Teor de umidade como fator limitante. }\end{array}$ & $\begin{array}{l}\text { Possibilidade de uso em olarias do entorno do Distrito } \\
\text { Federal para atender o mercado local. }\end{array}$ \\
\hline $\begin{array}{ll}\text { Uso } & \text { na } \\
\text { indústria } \\
\text { cimenteira }\end{array}$ & $\begin{array}{l}\text { Alternativa de disposição para lodos cujas } \\
\text { características apresentem limitação de } \\
\text { aplicação no solo. }\end{array}$ & $\begin{array}{l}\text { Necessidade de coprocessamento, a altas temperaturas, } \\
\text { promovendo poluição atmosférica, caso não operado } \\
\text { adequadamente. }\end{array}$ & $\begin{array}{l}\text { Assim como a incineração de resíduos, essa alternativa } \\
\text { deve ser evitada sempre que possível, devido aos riscos } \\
\text { de poluição atmosférica. }\end{array}$ \\
\hline
\end{tabular}


Entre as alternativas de disposição e usos potenciais selecionadas estão:

- disposição em aterro sanitário;

- uso agrícola;

- $\quad$ recuperação de áreas degradadas;

- $\quad$ uso em reflorestamento (silvicultura);

- $\quad$ produção de substrato vegetal; e

- $\quad$ uso como matéria-prima na fabricação de cerâmica vermelha.

\subsubsection{Uso e aplicação no solo}

Por conveniência, as alternativas que preveem aplicação no solo, seja para fins de cultivo ou recuperação de áreas degradadas, foram agrupadas, visto que os requisitos de qualidade são os mesmos, definidos nas resoluções n 375/2006 do CONAMA e no 003/2006 do CONAM-DF.

Para análise comparativa das características do lodo e os requisitos de qualidade foram utilizados os dados referentes ao último plano de caracterização realizado pela CAESB, em laboratório contratado, para as quatro maiores unidades geradoras de lodo do Distrito Federal, que serão consideradas separadamente.

A Tabela 5.37 traz as características dos lodos gerados nas ETEs do Distrito Federal, no tocante aos parâmetros inorgânicos e microbiológicos, assim como os limites máximos admissíveis, preconizados na legislação. 
Tabela 5.37 - Composição dos lodos gerados nas ETEs do Distrito Federal, segundo os parâmetros restritivos nas Resoluções do CONAMA e CONAM

\begin{tabular}{|c|c|c|c|c|c|c|c|}
\hline & \multirow[t]{2}{*}{ Parâmetros } & $\begin{array}{l}\text { ETEB } \\
\text { Norte }\end{array}$ & ETEB Sul & $\begin{array}{c}\text { ETE } \\
\text { Melchior }\end{array}$ & $\begin{array}{l}\text { ETE } \\
\text { Gama }\end{array}$ & $\begin{array}{c}\text { Resol. } \\
\text { CONAMA } \\
\text { No375/2006 }^{\circ}\end{array}$ & $\begin{array}{c}\text { Resol. } \\
\text { CONAM } \\
\text { No003/2006 }^{\circ}\end{array}$ \\
\hline & & \multicolumn{6}{|c|}{-----------------------mg/Kg--------------------- } \\
\hline \multirow{11}{*}{ 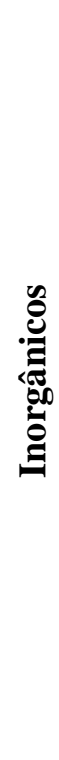 } & Arsênio & ND & ND & ND & 5,33 & 41 & 20 \\
\hline & Bário & 63,48 & 51,31 & 81,96 & 82,28 & 1300 & 650 \\
\hline & Cádmio & ND & ND & ND & ND & 39 & 13 \\
\hline & Cobre & 83,01 & 66,24 & 75,17 & 86,15 & 1.500 & 1.000 \\
\hline & Chumbo & 14,32 & 19,91 & 23,41 & 25,94 & 300 & 250 \\
\hline & Cromo & 34,18 & 44,53 & 59,39 & 39,41 & 1.000 & 500 \\
\hline & Mercúrio & 1,83 & 1,78 & 1,53 & 1,26 & 17 & 4 \\
\hline & Molibdênio & 4,46 & 3,47 & 4,16 & 8,92 & 50 & 25 \\
\hline & Níquel & 11,79 & 12,52 & 13,47 & 10,19 & 420 & 210 \\
\hline & Selênio & ND & ND & ND & 115,03 & 100 & 8 \\
\hline & Zinco & 312,56 & 284,86 & 317,82 & 448,58 & 2.800 & 2.000 \\
\hline \multirow{10}{*}{ 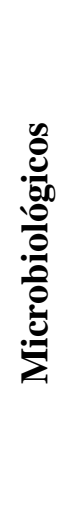 } & \multirow{5}{*}{$\begin{array}{c}\text { Coliformes } \\
\text { termotolerantes }\end{array}$} & \multicolumn{6}{|c|}{ 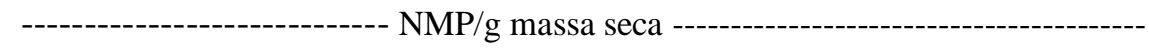 } \\
\hline & & \multirow{4}{*}{$4,52 \mathrm{E}+05^{(\mathrm{a})}$} & \multirow{4}{*}{$5,09 \mathrm{E}+06^{(\mathrm{b})}$} & \multirow{4}{*}{$1,96 \mathrm{E}+05^{(\mathrm{c})}$} & \multirow{4}{*}{$1,64 \mathrm{E}+06^{(\mathrm{d})}$} & \multicolumn{2}{|c|}{ Classe A } \\
\hline & & & & & & $<10^{3}$ & $<10^{3}$ \\
\hline & & & & & & \multicolumn{2}{|c|}{ Classe B } \\
\hline & & & & & & $<10^{6}$ & $<2.10^{6}$ \\
\hline & \multirow{5}{*}{$\begin{array}{l}\text { Ovos viáveis } \\
\text { de Helmintos }\end{array}$} & \multirow{5}{*}{$1,60^{(\mathrm{e})}$} & $-\mathrm{N}^{\mathrm{o}}$ de & vos viáveis d & helmintos/s & massa seca-- & --------------- \\
\hline & & & \multirow{4}{*}{$1,78^{(\mathrm{f})}$} & \multirow{4}{*}{$4,50^{(\mathrm{g})}$} & \multirow{4}{*}{$3,06^{(\mathrm{h})}$} & \multicolumn{2}{|c|}{ Classe A } \\
\hline & & & & & & $<0,25$ & $<1$ \\
\hline & & & & & & \multicolumn{2}{|c|}{ Classe B } \\
\hline & & & & & & $<10$ & - \\
\hline
\end{tabular}

Legenda: ND - Não detectado $\quad$ NMP - Número Mais Provável

Fonte: CAESB

Notas:

(a) Expressa a média de resultados de 19 amostras entre os anos de 2013 e 2014;

(b) Expressa a média de resultados de 16 amostras entre os anos de 2013 e 2014;

(c) Expressa a média de resultados de 14 amostras entre os anos de 2013 e 2014;

(d) Expressa a média de resultados de 8 amostras entre os anos de 2013 e 2014;

(e) Expressa a média de resultados de 14 amostras entre os anos de 2013 e 2014;

(f) Expressa a média de resultados de 15 amostras entre os anos de 2013 e 2014;

(g) Expressa a média de resultados de 13 amostras entre os anos de 2013 e 2014;

(h) Expressa a média de resultados de 8 amostras entre os anos de 2013 e 2014.

Segundo o que se observa na Tabela 5.37, para todos os metais listados, as concentrações encontradas nos lodos gerados nas ETEs do DF estão muito abaixo dos limites máximos estabelecidos pela Resolução nº3/2006 do CONAM-DF e pela Resolução nº375/2006 do CONAMA. Apenas a concentração dos elementos Mercúrio (ETE Brasília Norte) e Zinco 
(ETE Gama) atingem percentuais mais próximos aos limites admissíveis pela resolução CONAM (mais restritiva), cerca de $46 \%$ e $22 \%$, respectivamente. Mesmo assim, para que o Mercúrio atingisse a carga acumulada teórica máxima, definida na resolução mencionada (1,2 kg/ha), seriam necessárias 82 aplicações de lodo da ETE Brasília Norte, com uma dose de aplicação de lodo de 8 ton/ha.

Nota-se também pela Tabela 5.37 que, segundo os parâmetros microbiológicos monitorados, nenhuma das estações de tratamento de esgotos no DF gera lodo classe A.

No que se refere aos coliformes termotolerantes, apenas as ETEs Brasília Norte e Melchior atendem os limites máximos de concentração, estabelecidos na Resolução CONAMA para lodo classe B, enquanto para a resolução CONAM, somente a ETE Brasília Sul não se enquadra no lodo classe B.

Quanto ao número de ovos viáveis de helmintos, todas as ETEs monitoradas se enquadram como lodo classe B.

A Resolução $n^{\circ}$ 375/2006 do CONAMA define que, para lodo Classe A, além dos parâmetros avaliados (coliformes termotolerantes e ovos viáveis de helmintos), a composição do lodo deve atender aos limites de concentração de Salmonella e vírus entéricos, entretanto, como nenhuma das ETEs monitoradas atendeu as exigências quantos aos limites dos parâmetros microbiológicos monitorados, tais análises foram dispensáveis para a classificação do lodo.

A Tabela 5.38 apresenta a concentração dos principais parâmetros agronômicos nos lodos gerados nas ETEs do DF que, apesar de não serem restritivos, foram considerados na avaliação por identificarem as características de interesse para as alternativas que preveem a aplicação no solo. Com relação a esses parâmetros, a legislação não estabelece limites mínimos ou máximos no lodo, mas exige que o uso de lodo para o cultivo seja antecedido por um projeto agronômico, em que deverão ser consideradas as necessidade nutricionais de cada planta, condicionando a dose de aplicação máxima do lodo de esgoto ao atendimento de critérios relacionados a alguns parâmetros, entre eles estão o Nitrogênio e o $\mathrm{pH}$. 
Tabela 5.38 - Composição dos lodos gerados nas ETEs do Distrito Federal - Parâmetros agronômicos

\begin{tabular}{|c|c|c|c|c|c|}
\hline \multirow[b]{2}{*}{ Parâmetros } & \multirow[b]{2}{*}{ Unidade } & \multicolumn{4}{|c|}{ Concentração - base seca } \\
\hline & & ETEB Norte & ETEB Sul & $\begin{array}{c}\text { ETE } \\
\text { Melchior }\end{array}$ & $\begin{array}{c}\text { ETE } \\
\text { Gama }\end{array}$ \\
\hline pH em água destilada & - & 6,6 & $7,7,50$ & $\begin{array}{c}5,8 \\
\end{array}$ & $7,7,09$ \\
\hline Umidade & $\%$ & 83 & 84 & 81 & 84 \\
\hline Fósforo Total & g. $\mathrm{kg}^{-1}$ & & & & 32,9 \\
\hline Matéria Orgânica Total ${ }^{(8)}$ & g. $\mathrm{kg}^{-1}$ & 516,38 & 491,22 & 413,42 & 543,49 \\
\hline Carbono Orgânico Total & g. $\mathrm{kg}^{-1}$ & 293,4 & 279,1 & 234,9 & 308,8 \\
\hline Nitrogênio Total Kjedahl & g. $\mathrm{kg}^{-1}$ & 54,3 & 60,9 & 40,5 & 43,9 \\
\hline Nitrogênio Amoniacal & g. $\mathrm{kg}^{-1}$ & 6,0 & 4,7 & 1,5 & 5,1 \\
\hline Nitrogênio Total & g. $\mathrm{kg}^{-1}$ & 54,3 & 60,9 & 40,5 & 43,9 \\
\hline Enxofre & g. $\mathrm{kg}^{-1}$ & 24,0 & 14,0 & 24,6 & 6,7 \\
\hline Cálcio Total & g. $\mathrm{kg}^{-1}$ & 12,4 & 10,4 & 6,8 & 5,8 \\
\hline Magnésio Total & g. $\mathrm{kg}^{-1}$ & 2,6 & 1,6 & 1,7 & 1,0 \\
\hline Potássio Total & g. $\mathrm{kg}^{-1}$ & 1,1 & 2,2 & 1,1 & 1,0 \\
\hline Sódio Total & g. $\mathrm{kg}^{-1}$ & 0,6 & 0,7 & 0,7 & 1,4 \\
\hline Alumínio Total & g. $\mathrm{kg}^{-1}$ & 22,6 & 17,4 & 37,4 & 42,9 \\
\hline Ferro Total & g. $\mathrm{kg}^{-1}$ & 12,9 & 15,9 & 21,7 & 21,7 \\
\hline
\end{tabular}

Fonte: CAESB

Diversos estudos com lodos de esgotos apontam como vantagem o suprimento de macro e micronutrientes, presentes no lodo de esgotos, dispensando o uso de fertilizantes químicos (Gonçalvez et al., 2000; Lemanski et al., 2006; Pogiane et al., 2006; Skorupa et al., 2006; Barbosa et al., 2007; Silva et al., 2007; Lira et al., 2008; Brito, 2013; Junkeira, 2013). Além dos nutrientes, cita-se também o teor de matéria orgânica, a umidade e o pH, que melhoram as propriedades físicas e químicas do solo (Skorupa et al., 2006; Campos e Alves, 2008; Souza et al., 2006; Bento, 2009).

Pela Tabela 5.38 nota-se que os lodos gerados nas ETEs do Distrito Federal, reúnem as características desejáveis para uso de lodo nas alternativas de disposição no solo (agricultura, silvicultura, recuperação de áreas degradadas). Vale ressaltar, entretanto, que o teor de $\mathrm{N}$ contido no lodo de esgoto (40,5 a 60,9 g kg-1), comparado com os metais pesados e considerando a necessidade das plantas, poderá ser o fator mais restritivo ao cálculo da taxa de aplicação do material, em vista do potencial de lixiviação do nitrato que, após a mineralização da matéria orgânica (M.O.) do lodo, teria como consequência a contaminação do lençol freático (Oliveira, 2000). 
Em suma, as características dos lodos das estações Brasília Norte e Melchior seriam compatíveis com as alternativas de aplicação de lodo no solo, seja na agricultura, silvicultura ou recuperação de áreas degradadas, para ambas as resoluções. Entretanto, a Resolução n³75/2006 do CONAMA estabelece um decurso de prazo de 5 anos, entre sua publicação e adequação as unidades gerenciadoras de lodo (UGL), impondo que a partir de então, somente os lodos Classe A, sejam passíveis de aplicação na agricultura e silvicultura.

No caso dos lodos gerados nas ETEs Gama e Brasília Sul, sob as condições atuais, a única alternativa possível para aplicação de uso no solo seria a recuperação de áreas degradadas, visto que a Resolução $n^{\circ}$ 003/2006 - CONAM classifica esses lodos como Classe C e estabelece em seu artigo 42, item III, alínea b: “É permitido para reflorestamento $e$ revegetação de áreas mineradas - espécies arbóreas, exóticas e nativas".

\subsubsection{Produção de substrato vegetal}

O uso do lodo de esgotos na fabricação de substrato vegetal constitui uma alternativa de interesse para disposição final, na medida em que promove o aproveitamento de nutrientes e matéria orgânica, presentes no lodo.

Segundo Andreoli et al. (2006), as concentrações de metais pesados e das características microbiológicas (coliformes termotolerantes e viabilidade de ovos de helmintos) devem ser previamente avaliadas e se submeterem aos mesmos requisitos estabelecidos nas Resoluções do CONAMA e CONAM. Deve existir um controle de sanidade do substrato, pois, caso não seja totalmente esterilizado, provavelmente exija a desinfecção dos canteiros de mudas.

Como observado na Tabela 5.33, as concentrações de metais pesados nos lodos gerados nas ETEs do Distrito Federal não impõem restrições de uso desse lodo para a fabricação do substrato, uma vez que atendem aos padrões estabelecidos na legislação.

No que se refere aos aspectos de sanidade, para todas as estações de tratamento de esgotos do DF, os níveis de concentração de coliformes termotolerantes e ovos viáveis de helmintos exigirão um processo de higienização que, segundo diversos autores, pode ser atingido por meio da compostagem do resíduo (Pegorini, 2002; Sanchez-Monedero et al., 2004; Andreoli et al.,2006; Szabová et al, 2010). 
Em um estudo sobre a compostagem e vermicompostagem utilizando lodo de esgoto da ETE Brasília Norte, os resultados demonstraram eficiência de inativação de ovos de helmintos variando de 93 a 100\% (Corrêa et al., 2007). Nesse estudo, o lodo foi compostado misturando resíduo de poda de árvores e serragem, fornecidos pela NOVACAP - Companhia Urbanizadora da Nova Capital do Brasil - a custo zero, o que indica a possibilidade de uma parceria entre essas duas instituições para uma solução conjunta para os resíduos oriundos de suas atividades.

Segundo Andreoli et al. (2006), para a produção de uma tonelada de substrato vegetal no processo de compostagem com o lodo de esgoto, são necessários de 2 a $3 \mathrm{~m}^{3}$ de poda para cada $1 \mathrm{~m}^{3}$ de lodo.

Segundo dados publicados pela NOVACAP (2015), os resíduos de podas e de canteiros são encaminhados e armazenados nos viveiros da Companhia, não tendo uma destinação definida. Os números que caracterizam os parques e jardins do Distrito Federal são:

- 128.460.638 $\mathrm{m}^{2}$ de gramados e vegetação nativa

- 2,8 milhões de mudas de flores ornamentais

- 5 milhões de árvores plantadas

- 80 mil mudas de árvores plantadas anualmente

- 13,2 mil $\mathrm{m}^{3}$ de lenha produzida por ano

- $67 \mathrm{~m}^{3}$ de madeira e $150 \mathrm{~m}^{3}$ de galhos e folhas

Dessa forma, se todo o resíduo de poda da NOVACAP fosse separado e utilizado no processo de compostagem com o lodo de esgotos, seriam aproveitados apenas cerca $2 \%$ da produção anual de lodo do Distrito Federal. Isso demonstra que essa alternativa, apesar de viável, demanda estudos de viabilidade econômica, não apenas no tocante à operacionalização do processo de compostagem (área para instalação das leiras, maquinário, sistema de aeração de leiras, mão de obra, entre outros), mas também relacionados à aquisição de material estruturante e de transporte, tanto desse material quanto do lodo, até o local de implantação do sistema.

Em termos gerais, os custos do substrato a partir do uso de lodo de esgotos correspondem a $50 \%$ do custo em relação ao substrato comercial (Andreoli et al., 2006). Isso apresenta essa alternativa como vantajosa, não apenas do ponto de vista técnico, por dar uma solução adequada para um resíduo problemático, mas também por atender a uma demanda de um 
mercado em potencial, visto as extensas áreas de parques e jardins do DF, bem como da elevada produção de mudas mencionadas pela NOVACAP.

\subsubsection{Uso como matéria-prima na fabricação de cerâmica vermelha}

O uso de lodos de esgotos na fabricação de cerâmica vermelha, apesar das possíveis vantagens, deve considerar como a adição do lodo pode afetar as etapas do processo de fabricação (conformação, secagem e queima) e as propriedades dos produtos finais, tais como a resistência mecânica, o aspecto final, a cor, a porosidade e a absorção de água (Diaz, 2013).

No Distrito Federal existem cerca de cinco olarias, localizadas em São Sebastião e no Novo Gama, mas de produções pequenas e que não atendem a demanda do mercado local. Essa demanda é atendida principalmente por três polos cerâmicos do estado de Goiás, são eles: Anápolis/Campo Limpo, Silvânia e Nerópolis (Medeiros, 2006) com distância média do Distrito Federal de $170 \mathrm{Km}$.

Segundo Durante-Ingusa et al. (2006), diversos estudos realizados com lodos de diferentes origens e composições, apontam a umidade como fator mais limitante ao emprego desse resíduo na fabricação de cerâmica vermelha, seguido do conteúdo de matéria orgânica. $O$ primeiro dificulta o processo operacional e o segundo compromete a qualidade do bloco, visto que causa perda excessiva de massa durante a queima.

No Distrito Federal, os lodos gerados nas ETEs, apresentam teores de umidade média entre 81 e $84 \%$ e teor médio de matéria orgânica entre 41 e 54\% (Tabela 5.33), ambos desqualificariam os lodos das ETEs do DF para essa alternativa, pois segundo recomendação da literatura, os lodos com teores de matéria orgânica superiores a 30 - 40\% podem provocar a perda de qualidade do bloco cerâmico, pelos motivos acima expostos. Da mesma forma, lodos com umidade acima de $80 \%$ limitariam sobremaneira as dosagens do lodo na mistura da matéria-prima para fabricação de blocos cerâmicos, cuja umidade ideal está entre 10 e 30\% (Durante-Ingusa et al., 2006 ).

Considerando as recomendações dos autores, os lodos de esgotos provenientes das ETEs do Distrito Federal deveriam passar por um processo de secagem adicional, para redução do teor de umidade e matéria orgânica no lodo, adequando-os aos limites recomendados e 
transformando-o em um resíduo aceitável como matéria-prima para fabricação de cerâmica vermelha.

\subsubsection{Disposição em Aterro Sanitário}

Não existem requisitos de qualidade referentes à composição dos lodos de esgotos para disposição em aterros sanitários. A prática mais usual no Brasil é a codisposição com o lixo urbano. Entretanto, para dispor o lodo é preciso que esse tenha pelo menos $30 \%$ de sólidos, de outra forma dificulta-se a compactação e o trabalho das máquinas sobre o aterro (Jordão e Pessoa, 2005).

Segundo a recomendação de literatura, para a disposição dos lodos provenientes das ETEs do DF seriam necessários processos de secagem complementar, visto que o teor de sólidos não supera 19\% (Tabela 5.37), em todas as ETEs monitoradas.

O aterro sanitário no Distrito Federal está em fase de conclusão e poderá receber os lodos, caso esses não possam ser utilizados em nenhuma das alternativas que possibilitem o aproveitamento do material (nutrientes e matéria orgânica). 


\section{CONCLUSÕES E RECOMENDAÇÕES}

O presente trabalho teve por principal objetivo diagnosticar a gestão dos lodos de esgotos provenientes das ETEs do Distrito Federal, de maneira a subsidiar uma análise técnica e ambiental das condicionantes que envolvem a problemática do tratamento e disposição do lodo e a nortear o processo de tomada de decisão na seleção de alternativas para gestão de lodos de estações de tratamento de esgotos sanitários.

Nesta pesquisa foram avaliados dados obtidos junto à CAESB, que compreenderam uma série histórica de 2004 a 2014; foram levantados dados de concentrações de constituintes dos esgotos afluentes às ETEs (32.441 dados), além de dados de vazões de esgotos afluentes (atuais e de projeto) e de produção de lodo. Os dados relativos ao desempenho operacional da ETE selecionada como Estudo de Caso (ETE Brasília Norte) também foram verificados e propiciaram uma análise do comportamento do lodo e das eficiências dos tratamentos da fase sólida empregados.

O diagnóstico do manejo de lodo nas ETEs do DF confirmou o que cita Ramos (2008) acerca dos descartes de lodo em reatores anaeróbios, visto que a remoção de lodos nessas unidades ocorre de maneira empírica e sem rotinas estabelecidas, não tendo sido identificados padrões para a definição dos descartes em quaisquer das 11 ETEs investigadas.

Uma avaliação preliminar dos dados disponibilizados permitiu, ainda, verificar as características dos lodos gerados nas ETEs do Distrito Federal, no que se refere à sanidade e aos constituintes de maior interesse para uso agrícola do lodo. Foi observada uma tendência de maior concentração de ovos de helmintos nos lodos daquelas ETEs cuja população contribuinte possui perfil socioeconômico menos desenvolvido em relação aos padrões do Distrito Federal. Essa constatação leva à inferência de que esse parâmetro poderia ser usado como um indicador para nortear ações voltadas para a prevenção e tratamento de verminoses e de educação ambiental, nas regiões onde há grande incidência de helmintos no lodo.

Quando analisadas as características químicas dos lodos provenientes das ETEs do Distrito Federal, em comparação com outras ETEs no Brasil, os lodos gerados no DF apresentaram baixos teores de metais e elevada concentração de matéria orgânica e de macronutrientes, 
possivelmente associados, entre outros fatores, à inexistência de polos industriais de grande porte na região em estudo e aos processos de tratamento de esgotos que foram concebidos para realizarem a remoção de nutrientes.

O diagnóstico da gestão do lodo mostrou uma grande variabilidade dos lodos gerados ao longo das etapas de tratamento de esgotos, nas diversas ETEs monitoradas, em que se destacaram as ETEs Brasília Sul e Brasília Norte.

O estudo de caso permitiu a investigação das variáveis e condicionantes que caracterizam os processos de produção e condicionamento dos lodos. A avaliação do desempenho operacional das unidades de geração e tratamento da fase sólida da Estação de Tratamento de Esgotos Brasília Norte ofereceu um panorama acerca do comportamento do lodo e das eficiências alcançadas em cada uma das etapas. Isso pode nortear o planejamento de ações para correção de rumos, otimização de processos e melhorias operacionais, visando principalmente ao atendimento aos requisitos de qualidade dos lodos segundo as alternativas de disposição final selecionadas. Essa verificação permitiu delinear as seguintes conclusões:

1. A carga de lodo primário gerada na ETEB Norte é bem superior àquela projetada, superando, algumas vezes, mais de $200 \%$ do volume inicialmente previsto. Isso explica, em parte, as concentrações do lodo sempre abaixo dos valores normalmente registrados pela literatura.

2. O volume de lodo gerado em uma ETE sempre será um fator crítico no gerenciamento do resíduo, de forma que devem ser definidos os parâmetros operacionais que minimizem a produção de lodo, e essas condições ótimas devem ser buscadas e mantidas. O regime de extração de lodo no Decantador Primário na ETEB Norte, verificado em 2014, mostrou exercer influência sobre a captura de sólidos no adensador por gravidade; dessa forma, ele passa a ter relevante importância e deverá ser objeto de verificações futuras.

3. O adensador por gravidade na ETEB Norte apresenta uma variação significativa dos teores de sólidos no lodo adensado ao longo do tempo (desvio padrão entre 0,71 a 1,02\%), com concentrações limítrofes aos valores reportados na literatura especializada. Isso sugere que existe suscetibilidade da unidade às influências externas, como a qualidade dos sólidos afluentes. 
4. O adensador por gravidade da ETEB Norte apresenta desempenho satisfatório da captura de sólidos, mesmo com TAS elevadas. Entretanto, a concentração de sólidos afluente e a TAS não são os parâmetros que mais afetam a eficiência de captura de sólidos. Recomendam-se estudos futuros da influência de outros aspectos na captura de sólidos, tais como as características dos sólidos afluentes ao adensador, a presença de óleos e graxas, sólidos provenientes de reciclos internos, entre outros.

5. O desempenho dos adensadores por flotação na ETEB Norte, para captura de sólidos, mostrou-se acima dos valores mencionados na literatura clássica. $\mathrm{O}$ adensamento do lodo, verificado por meio da concentração de sólidos no lodo adensado, esteve dentro da faixa típica. As taxas de aplicação de sólidos verificadas ao longo do tempo apresentaram valores sempre abaixo das taxas indicadas para adensadores por flotação.

6. A avaliação do funcionamento com apenas um adensador por flotação, testando o seu desempenho com taxas de aplicação mais elevadas seria recomendável, de maneira a verificar a possibilidade de reduzir os volumes de lodo gerados e os custos operacionais.

7. Os digestores anaeróbios primários da ETEB Norte são responsáveis pela estabilização de todo o lodo gerado na estação. A análise dos dados, considerando os parâmetros de controle \%ST no lodo digerido, relação SV/ST, eficiência na remoção de SV, TDH, e $\mathrm{pH}$, indicou um baixo desempenho dessa unidade e um variabilidade significativa do seu comportamento, ao longo do tempo. Essa variação pode ser explicada, principalmente, pela interferência do tratamento biológico e químico da fase líquida, uma vez que $70 \%$ da carga orgânica afluente ao digestor são provenientes dessas etapas; dessa forma, qualquer desequilíbrio nessas fases, conduzem a uma geração maior de lodo e, em consequência, em um impacto direto em variáveis de controle, tais como TDH e COV.

8. Os digestores anaeróbios primários na ETEB Norte foram projetados para tratar apenas o lodo primário. O acréscimo de carga, advindo do aporte de lodo aeróbio adensado e lodo químico, interfere significativamente no processo de estabilização do lodo, que apresenta concentrações de sólidos afluentes abaixo do reportado na literatura, alta relação SV/ST, baixa eficiência na remoção de $\mathrm{SV}$, e remoção de 
bactérias do grupo coliformes termotolerantes muitas vezes aquém do necessário para a classificação do lodo como Classe B.

9. É importante o estudo para otimização da digestão anaeróbia de lodo na ETEB Norte, de maneira a nortear a adoção de medidas, tais como: a ampliação da capacidade de digestão, visando ao amortecimento de cargas afluentes oriundas de desequilíbrios no tratamento biológico e químico dos esgotos; a melhoria do processo de digestão, a partir do aproveitamento do biogás para implantar a digestão termofílica, entre outros.

10. As prensas desaguadoras na ETEB Norte, segundo dados verificados, apresentam produtividade superior ao esperado e captura de sólidos dentro da faixa típica. Entretanto, os teores de sólidos no lodo desaguado estiveram sempre abaixo do reportado. Entre as possíveis causas para se explicar esse comportamento está o baixo desempenho da digestão do lodo ao longo do período investigado.

11. Os volumes de lodos desaguados diariamente pelas prensas na ETEB Norte mostraram expressiva variação ao longo do tempo (desvios padrão entre 1.017 e $4.659 \mathrm{~m}^{3}$ ), corroborando a condição identificada por ocasião do diagnóstico da gestão do lodo nas ETEs do DF, em que os volumes desaguados retratam principalmente a capacidade de desaguamento do lodo, diminuindo ou aumentando conforme as condições operacionais da unidade de desaguamento de lodo permitam.

12. O consumo de polímero na ETEB Norte é outro parâmetro que está inter-relacionado com a eficiência da digestão do lodo e, demonstrou, ao longo do período, um aumento gradativo. Deve-se ressaltar a importância do estudo de melhorias nas etapas anteriores, de forma a minimizar custos e reduzir a interferência do polímero nas características do lodo. Os dados e conclusões obtidos, entretanto, devem ser considerados com cuidado, pois no período também houve mudança do fornecedor do polímero, o que pode também influenciar o consumo do produto.

Em suma, a análise dos dados levantados demonstrou ser tecnicamente viáveis para os lodos gerados nas ETEs do Distrito Federal, considerando o lodo sem tratamento adicional, as seguintes soluções de disposição final:

- Recuperação de áreas degradadas, com aproveitamento de nutrientes de todo o lodo com qualidade que atenda aos padrões definidos na legislação; 
- Uso na produção de substrato, coprocessado com resíduos de poda da NOVACAP;

- Codisposição em aterro sanitário do Distrito Federal dos lodos sem aptidão agrícola, segundo os padrões da legislação.

Algumas premissas devem ser observadas para a concretização das alternativas mencionadas, entre elas podem ser citadas as seguintes:

- Deve ser realizado o manejo distinto de lodos com qualidades diferentes, priorizando os usos benéficos, isto é, evitar o armazenamento conjunto, temporário ou não, com os lodos com características fora dos padrões de controle;

- Deve-se evitar o armazenamento temporário de lodos que atendem aos padrões de qualidade para os usos benéficos em áreas que possam propiciar sua contaminação Deve-se evitar o armazenamento temporário de lodos que atendem aos padrões de qualidade para os usos benéficos em áreas que possam propiciar sua contaminação ou perda da qualidade, como pátios sem impermeabilização ou cobertura ou que recebam outros resíduos do tratamento de esgotos.

- Devem-se avaliar os aspectos técnicos e econômicos relacionados ao gerenciamento e operacionalização das alternativas elencadas, para a estruturação de uma análise de Custos e Benefícios, considerando os seguintes fatores: transporte do lodo desaguado das ETEs até as possíveis áreas de destinação; implantação das estruturas e aquisição de equipamentos; monitoramento (controle do processo, coleta de amostras e análises); operação (qualificação de mão de obra, produtividade, insumos); gestão da informação (banco de dados, rastreabilidade e responsabilidades); e processos de licenciamento.

As características qualitativas dos lodos gerados nas ETEs do Distrito Federal tornam esse resíduo do tratamento de esgotos em um produto em potencial, à medida que desperta o interesse para o uso agrícola.

Tanto os dados disponibilizados quanto os estudos realizados ao longo dos anos com lodos de ETEs do Distrito Federal demonstram que o uso agrícola é uma alternativa em potencial para destinação final desse lodo. Isso porque, as caracterizações realizadas indicaram concentrações de metais pesados significativamente inferiores aos limites máximos estabelecidos na legislação aplicável, além de vantagem agronômica em relação a fertilizantes químicos. Entretanto, os dados também indicaram problemas quanto à 
sanidade e grau de estabilização do lodo, cujas soluções são menos complexas do que a remoção de metais pesados, por exemplo.

No passado, esse lodo era disponibilizado gratuitamente para os agricultores da região e do entorno, que demandavam quase a totalidade dos lodos produzidos. Com as restrições impostas pela legislação (Resoluções No 375/2006 do CONAMA e No 003/2006 do CONAM), os lodos passaram a se acumular nos pátios de estocagem e em unidades intermediárias das ETEs.

O presente estudo demonstrou que os maiores obstáculos a serem vencidos para a implementação da disposição agrícola do lodo são, na verdade, tecnicamente simples, pois envolvem o emprego de processos para higienização do lodo, de maneira a atender os padrões para lodo Classe A, além da redução de umidade, o que reduziria os custos com transporte e manejo do lodo.

Além do processo de compostagem, já mencionado, a higienização do lodo, por meio do processo de solarização, vem sendo objeto de diversos estudos. No processo de solarização de lodo de esgoto, a redução na concentração de microrganismos patogênicos pode ocorrer por meio de um processo simples de secagem do lodo com cobertura plástica, que além de ser de baixo custo, busca aproveitar as condições climáticas de alta insolação e temperatura ambiente (Ferreira, 2001; Cherubini et.al, 2002; Silva, 2007; Argel, 2010).

Conforme mencionado no item 5.1.9, a CAESB vem, ao longo dos últimos anos, nos períodos de estiagem, empregando o processamento do lodo gerado nas ETEs do DF, por meio de secagem natural com exposição ao sol. Entretanto, com o manejo atual, nos períodos chuvosos, as alternativas para disposição do lodo são significativamente limitadas, levando a grandes volumes de lodos de esgotos estocados em estruturas das próprias ETEs. Dessa forma, recomenda-se a continuidade dos estudos para comprovação dos efeitos da solarização no processamento de lodo empregado e para o delineamento de alternativas que possibilitem a continuidade das atividades durante a estação das chuvas, como por exemplo, o uso de estufas agrícolas. 


\section{REFERÊNCIAS BIBLIOGRÁFICAS}

Aisse, M.N., van Haandel, A.C., von Sperling, M., Campos, J.R., Coraucci Filho, B., Alem Sobrinho, P. (1999). "Tratamento e destino final do lodo gerado em reatores anaeróbios". In: Campos, J.R. (ed) Tratamento de esgotos sanitários por processo anaeróbio e disposição controlada no solo, Rio de Janeiro, RJ: ABES, 271-299.

Além Sobrinho, P. (2000). "Tratamento de esgoto e geração de lodo". In: Bettiol, W ; Camargo, O. A (eds). Impacto ambiental do uso agrícola do lodo de esgoto. Jaguariúna: EMBRAPA, p11 - 108

Alem Sobrinho, P.(2001). “Tratamento de esgoto e geração de lodo. In: Tsutiya, M.T. Biossólidos na agricultura. São Paulo: SABESP. Cap.3, p.41-87. Cap.2, p.7-40..

Andrade Neto, C.O. e Campos, J.R. (1999). Introdução, In: Campos, J.R. (Ed), Tratamento de esgotos sanitários por processo anaeróbio e disposição controlada no solo, Rio de Janeiro, RJ, ABES, p.1-28.

Andraus, S.; Medeiros, M.L.B.; Borges, J.C.; Silva, S.M.C.P.; Toledo, E.B.(2001). "Aspectos sanitários; agentes patogênicos - bactérias entéricas" In: Reciclagem de Biossólidos - Transformando Problemas em Soluções, 2a edição, SANEPAR, FINEP, Curitiba, PR., $141-142$.

Andreoli, C. V.; Lara, A. I.; Fernandes, F. (1999). "Reciclagem de biossólidos Transformando problemas em soluções”. Curitiba: SANEPAR/FINEP.

Andreoli, C. V. (2000). "El lodo y su producción”. In: Anais do XXVIII Congresso Interamericano de Ingeniería Sanitária y Ambiental, Cancun: México.

Andreoli, C. V; Pegorini, E. S.(2000). Gestão pública do uso agrícola do lodo de esgoto. In: Impacto Ambiental do Uso do Lodo de Esgoto. Jaguariúna: EMBRAPA.

Andreoli, C. V.; Ferreira, A.C.; Chernicharo, C.A. (2003). "Secagem e higienização de lodos com aproveitamento do biogás”, cap. 05. In: Digestão de Resíduos Sólidos Orgânicos e Aproveitamento do Biogás. PROSAB 3. Vitória- ES,p.130 -133.

Andreoli, C.V.; Tamanini, C.R.; Holsbach, B.; Pegorini, E.S.; Neves, P.S. (2006). "Uso de lodo de Esgoto na Produção de Substrato Vegetal”. In: Andreoli, C. V (ed). Alternativas de Uso de resíduos do Saneamento - Projeto PROSAB, Rio de Janeiro, ABES.

Argel, K. D. R. V. (2010). "Caracterização de cenários de exposição a perigos microbiológicos relacionados ao uso agrícola de biossólidos" In: Dissertação de 
Mestrado - Universidade Federal de Viçosa. Programa de Pós-Graduação em medicina Veterinária, 92p.

Associação Brasileira de Normas Técnicas (1992). NBR 12.235: Armazenamento de resíduos sólidos perigosos, Rio de Janeiro, RJ, 14p.

Associação Brasileira de Normas Técnicas (2004). NBR 10.004: Resíduos sólidos Classificação, Rio de Janeiro, RJ, 71p.

Associação Brasileira de Normas Técnicas (2004). NBR 10.005: Procedimento para obtenção de extrato lixiviado de resíduos sólidos, Rio de Janeiro, RJ, 15 p.

Associação Brasileira de Normas Técnicas (2004). NBR 10.006: Procedimento para obtenção de extrato solubilizado de resíduos sólidos, Rio de Janeiro, RJ, 3p.

Associação Brasileira de Normas Técnicas (2004). NBR 10.007: Amostragem de resíduos sólidos, Rio de Janeiro, RJ, 21p.

Associação Brasileira de Normas Técnicas. NBR 12209 (2011). Elaboração de projetos hidráulicos-sanitários de estações de tratamento de esgotos sanitários, 53p.

Barbosa, G.M.de C.; Filho, J..T.; Brito, O.R.; Fonseca, I.C.B. (2007). "Efeito residual do lodo de esgoto na produtividade do milho safrinha." In: Revista Brasileira Ciência e Solo, 31, p.601-605.

Bennamoun, L. (2012). "Solar drying of wastewater sludge: A review". In: Renewable and Sustainable Energy Reviews, 16(1), pp. 1061-1073, ISSN 1364-0321.

Bento, M. A. B. (2009). "Avaliação da qualidade dos substratos minerados em cinco cascalheiras revegetadas no Distrito Federal” In: Dissertação de mestrado submetida à faculdade de Tecnologia, Departamento de Engenharia Florestal da Universidade de Brasília, 128p

Bettiol, W.; de Camargo, O (2006). "Lodo de esgoto: impactos ambientais na agricultura". In: Embrapa Meio Ambiente-Livros científicos (ALICE),

Bila, D. M.; Dezotti, M. (2003). "Fármacos no meio ambiente”.In: Química Nova, 26, p. 523-530,. ISSN 0100-4042.

Birkett, J. W.; Lester, J. N., (2003) Eds. "Endocrine Disrupters in Wastewater and Sludge Treatment Processes". LLC: USA: Lewis Publishers CRC Press, 1 ed..

Bonnet, B.R.P., Lara, A.I. de., Domaszak, S.C. (1998). Indicadores Biológicos de Qualidade Sanitária do Lodo de Esgoto. In: Andreoli, C.V., Bonnet, B.R.P. (eds.). Manual de Métodos para Análises Microbiológicas e Parasitológicas em Reciclagem Agrícola de Lodo de Esgoto: Curitiba: Sanepar, 11-26. 
Brasil. Câmara dos Deputados. Manejo ambientalmente saudável dos resíduos sólidos e questões relacionadas com esgotos. In: Agenda 21. Brasília, 1995.

Brito, A. P. F: (2013). “Avaliação da disposição de biossólido oriundo da ETE Araraquara (SP) em Argissolo vermelho. In: Dissertação de Mestrado apresentada ao Instituto de Geociências e Ciências Exatas do Campus de Rio Claro, da Universidade Estadual Paulista Júlio de Mesquita Filho, 68p.

Bundgaard, E.; Saabye, A. (1992). "State of the art on sewage sludge: environmental aspects and regulations of common sludge disposal methods". In: Anais: International Exhibition Congress of Solid Waste. Madrid : ISWA.

Campos, J. R. (ed) (1999). Tratamento de esgotos sanitários por processo anaeróbio e disposição controlada no solo, ABES, Projeto PROSAB, Rio de Janeiro, Brasil, $464 \mathrm{p}$.

CAESB, (2011). Relatório Administrativo CAESB - CAESB - companhia de Saneamento Ambiental do Distrito Federal, Brasília, Brasil.

CAESB (2012). SIESG - Sistema de Esgotamento Sanitário. CAESB - companhia de Saneamento Ambiental do Distrito Federal, Brasília, Brasil.

CAESB (2013). SIESG - Sistema de Esgotamento Sanitário. CAESB - companhia de Saneamento Ambiental do Distrito Federal, Brasília, Brasil.

Campos, F.S.; Alves, M.C. (2008). Uso do lodo de esgoto na reestruturação de solo degradado, In: R. Bras. Ci. Solo, 32:1389-1397

Campos, J.R. (2000). “Alternativas para o tratamento de esgotos, In: Castellano, E.G., Chaudhry, F.H. (eds), Desenvolvimento Sustentado: Problemas e Estratégias, São Carlos, SP, EESC-USP, p.87-106.

Cesário Silva, S.M. (2001) "Principais contaminantes do lodo." In: Sperling, M.V., Andreoli, C.V., Fernandes, F.(eds), Lodo de esgotos: tratamento e disposição final. Belo Horizonte: DESA-UFMG, 6, 69-121.

CETESB. Companhia de Tecnologia de Saneamento Ambiental. Aplicação de lodos de sistemas de tratamento biológico em áreas agrícolas: critérios para projeto e operação (Norma P4.230). São Paulo: CETESB, 1999.

Chao, I. R. S., (2001). "Diagnóstico e otimização dos adensadores por gravidade”. In: Congresso Brasileiro de Engenharia Sanitária e Ambiental, Joinville. (21). Anais eletrônico.Rio de Janeiro: ABES. P.1-6.

Chen, Yong (2012). "Sewage Sludge Aerobic Composting Technology Research Progress”. 
In: AASRI Procedia I:339-343.

Chernicharo, C.A.de L. (2007). In: Reatores Anaeróbios. 2ed. Belo Horizonte: Departamento de Engenharia Sanitária e Ambiental - UFMG, 380p.

Cherubini, C.; Andreoli, C.V., Ferreira, A.C., Carneiro, C. (2002). "Secagem e higienização do lodo de esgoto anaeróbio em leitos de secagem através da solarização". In: VI Simpósio Ítalo Brasileiro de Engenharia Sanitária e Ambiental. Vitória, ES.

CODEPLAN (2011). "Pesquisa Distrital Por Amostra de Domicílios - PDAD 2010/2011", Companhia de Desenvolvimento do Planalto Central, Brasília, Brasil.

CODEPLAN - Companhia de Planejamento do Distrito Federal . [Acesso em 12/12/2014]. Disponível em: http://www.codeplan.df.gov.br.

Conselho Nacional do Meio Ambiente - CONAMA. Resolução 375 de 29 de Agosto de 2006.

Corrêa, J.C.; Büll, L.T.; Paganini, W.S; Gurerrini, I.A. (2008). "Disponibilidade de metais pesados em Latossolo com aplicação superficial de escória, lama cal, lodos de esgoto e calcário.” In: Pesquisa Agropecuária brasileira, Brasília, 43(3), p.411-419.

Corrêa, R.S.; Fonseca, Y. M. F.; Corrêa, A. S. , (2007). "Produção de biossólido agrícola por meio da compostagem e vermicompostagem de lodo de esgoto". In: Revista Brasileira de Engenharia Agrícola e Ambiental, 11(4), p.420-426.

Cunha, A.M.; Cunha, G.M.; Sarmento, R.A.; Amaral, J.F.T.(2006). "Efeito de diferentes substratos sobre o desenvolvimento de mudas de Acacia sp". In: Revista Árvore, Viçosa, 30(2), p.207- 214.

Díaz, C.C.H. (2013). "Estudo da possibilidade de uso de lodo de esgoto e lama vermelha como matérias-primas cerâmicas”. Dissertação de mestrado, Escola Politécnica da Universidade de São Paulo, 197p.

Dohányos, M.; Zábranská, J.; Kutil, J.; Jenicek, P (2004). "Improvement of anaerobic digestion of sludge".In: Water Science \& Technology, 49(10), p.89-96.

Durante-Inguza, M.P., Andreoli, C.V; Nascimento, R.B do; Tinoco, J.D; Hoppen, C.; Pegorini, E.S., (2006). "Uso dos resíduos do saneamento na fabricação da cerâmica vermelha". In: Andreoli, C. V (ed). Alternativas de Uso de resíduos do Saneamento - Projeto PROSAB, Rio de Janeiro, ABES Prosab IV, p.283-352.

Esteller, M.V., Martínez-Valdés, H., Garrido, S. Uribe, Q. (2009). "Nitrate and phosphate leaching in a Phaeozem soil treated with biosolids, composted biosolids and norganic fertilizers" In: Waste Management, 29, p.1936-1944. 
EMBRAPA (1978). "Serviço Nacional de levantamento e conservação de solos". In: Levantamento de reconhecimento dos solos do Distrito Federal. Rio de Janeiro, Embrapa. Boletim Técnico 53, p. 7-17.

Faustino, R.; Kato, M.T.; Florêncio, L.; Gavazza, S., (2005). "Lodo de esgoto como substrato na produção de Senna siamea. Lam”. In: Revista Brasileira de Engenharia Agrícola e Ambiental, Campina Grande, 9, Supl., p.278-282.

Fayer, R., Morgan, U., Upton, S.J. (2000). "Epidemiology of Cryptosporidium: transmission, detection and identification", In: International Journal for Parasitology, (30), 305-1322.

Feitosa, M.C.A.(2009). “Lodo de esgoto: Algumas aplicações em Engenharia”In: Dissertação de mestrado. Universidade Católica de Pernambuco. 120p

Fernandes, F. (2000) "Estabilização e Higienização de Biossólidos". In: Betiol, W.; Camargo, O.A (eds.). Impacto Ambiental do Uso Agrícola do Lodo de Esgoto. Jaguariúna: Embrapa, 45-68.

Fernandes, F.; Lopes, D.D.; Andreoli, C. V.; Silva, S. M. C. P. (2001). "Avaliação de alternativas e gerenciamento do lodo na ETE”, In: Lodo e esgotos: tratamento e disposição final - princípios do tratamento biológico de águas residuárias, vol.06. DESA - UFMG (eds), SANEPAR. Belo Horizonte, MG, 308-309.

Ferreira, A.C., Andreoli, C.V.; Jürgensen, D. (1999). "Produção e características dos biossólidos”. In: Uso e Manejo do Lodo de Esgoto na Agricultura. Rio de Janeiro: PROSAB.

Ferreira, A.C., (2001). "Monitoramento do uso de estufa plástica e aproveitamento do biogás na secagem e desinfecção de lodo anaeróbio em leito de secagem”. In: Dissertação de Mestrado: Departamento de solos do setor de Ciências Agrárias da Universidade Federal do Paraná.

Fontes, C. M. A. (2003). "Potencialidades da Cinza de lodo de Estações de Tratamento de Esgotos como material suplementar para a produção de concreto com cimento Portland”. In: Dissertação de Mestrado em Engenharia Civil - UFRJ, COPPE, 120p.

Fontes, C. M. A. (2008). "Utilização das cinzas de lodo de esgoto e resíduo sólido em concretos de alto desempenho". Phd. In: Thesis. Federal University of Rio de Janeiro, Brazil.

Geyer, A.L.B., (2001). “Contribuição ao estudo da disposição final e aproveitamento da cinza de lodo de estações de tratamento de esgotos sanitários como adição ao 
concreto”. Tese de Doutorado, Programa de Pós-graduação em Engenharia Civil, UFRGS, Porto Alegre, RS, 200p.

Gonçalves, R.F; Luduvice, M., von Sperling, M. (2001). "Remoção da umidade de lodo de esgoto", cap 05. In: Lodo de Esgotos: Tratamento e Disposição Final - Princípios do Tatamento Biológico de Águas Residuárias, 6. DESA - UFMG, SANEPAR. Belo Horizonte, MG, 159;162; 173 - 174;180; 186; 187; 215; 232.

Guedes, M.C., (2005) "Ciclagem de nutrientes após aplicação de lodos de esgoto (biossólidos) sobre Latossolo cultivado com Eucalyptus grandis". In: Tese de doutorado - Escola Superior de Agricultura Luiz de Queiroz, Piracicaba,154 p.

Haandel, A.; Além Sobrinho, P. (2006) "Produção e constituição do lodo de esgoto", In: Andreoli, C. V (ed). Alternativas de Uso de resíduos do Saneamento - Projeto PROSAB. Rio de Janeiro: ABES.

Hart, J.B.; Nguyen, P.V.; Urie, D.h.; Brochkway, D.G., (1988). "Silvicultural use of wastewater sludge". In: Jornal of Forestry, 17, p.17-24.

Ilhenfeld, R.G.K.; Andreoli, C.V.; Lara, A. (1999). "Higienização do lodo de esgoto", In: Uso e Manejo do Lodo de Esgoto na Agricultura. PROSAB. Rio de Janeiro, RJ, 34; $44 ; 51-52 ; 55$.

Jamali, M.K., Kazi, T.G., Arian, M.B., Afridi, H.I.(2009). "Heavy metal accumulation in different varieties of wheat (Triticum aestivum L.) grown in soil amended with domestic sewage sludge” In: Journal of Hazardous Materials, 164, 1386-1391.

Jonsson, C.M.; Maia, A.H.N (2007). Avaliação da toxicidade do lodo de esgoto de duas estações de tratamento para o invertebrado aquático Daphnia similis. Pesticidas: r. ecotoxicologia e meio ambiente, Curitiba, 17, jan./dez.

Jordão, E.P. e Pessôa, C.A. (2005). Tratamento de Esgotos Domésticos, $4^{\mathrm{a}}$ ed, Rio de Janeiro: SEGRAC.

Junior, M.C.; Boschi, A.O.; Motta, J.F.M.;Tanno, L.C.; Sintoni, A.; Coelho, J.M.; Caridade, M. (2010). "Panorama e Perspectivas na Indústria de Revestimentos Cerâmicos no Brasil”. In: Cerâmica Industrial, 15(3), p. 7-18.

Junqueira, L. P.(2013). "Efeito de fertilizante, fungicida e indutor de resistência na produtividade, taxa de vingamento de flores, incidência e severidade de como se e características físicas de frutos de limeira ácida 'Tahiti”. In: Tese de doutorado, Faculdade de agronomia e medicina veterinária, UNB, 134p.

Kiehl, E. J.(1998). “Manual de Compostagem: maturação e qualidade do composto” editado 
pelo autor. Piracicaba.

Korentajer, L. (1991). "A review of the agricultural use of sewage sludge: benefits and potential hazards", In: Water S.A., 17(3),189-196.

Kroiss, H., Zessner. (2007). "Ecological and Economical Revelance of Sludge Treatment and Disposal Options", In: Conference Proceedings - Moving Forward Wasterwater Biosolids Sustainability - Technical, Managerial and Public Synergy, $4^{a}$ Canadian Organic Residuals and Biosolids Conference, New Brunswic, 24-27.

Khanbilvardi, R., Afshari, S., "Sludge Ash as Fine Aggregate for Concrete Mix". In: Journal of Environmental Engineering, 121(9), pp. 633-638, 1995.apud Fontes, C. M. A. (2003). "Potencialidades da Cinza de lodo de Estações de Tratamento de Esgotos como material suplementar para a produção de concreto com cimento Portland”. In: Dissertação de Mestrado em Engenharia Civil - UFRJ, COPPE, XXp.

Lasheen, M.R., Ammar, N.S. (2009) “Assessment of metals speciation in sewage sludge and stabilized sludge from different wastewater treatment plants". In: Journal of Hazardous Materials, 164, p. 740-749.

Lemanski, J.; Silva, J.E. (2006). "Utilização do biossólido da CAESB na produção de milho no Distrito Federal”. Seção IX - Poluição do Solo e Qualidade Ambiental, R. Bras.Ci. Solo, 30, p.741-750.

Lemanski, J.; Silva, J.E.; Pereira, C.E.B. (2007). "Sobrevivência de ovos de helmintos na reciclagem agrícola do lodo de esgoto em milho e soja no Distrito federal. In: Anais do XXXI Congresso Brasileito de Ciência do Solo: Conquistas \& Desafios da Ciência do Solo brasileita, Gramado-RS: SBCS, CD-ROM.

Leschber, R., Spinosa, L. (1998) "Developments in Sludge Characterization in Europe".In: Water Science and Technology, London, 38(2), 1-7.

Lira, A.C.S., Guedes, M.C., Schalch, V. (2008). "Reciclagem de lodo de esgoto em plantação de eucalipto: carbono e nitrogênio", In: Revista Engenharia Sanitária Ambiental, 13(2), 207-216.

Lima, M. M., Yamanishi, K. O., (1999). "Fruticultura como alternativa economicamente viável para o Distrito Federal”. In: Silva, J.M.de M. (coord), Incentivo à Fruticultura no Distrito Federal: Manual de fruticultura (2aed),- Brasília: OCDF.

Luduvice, M.; Fernandes, F. "Principais tipos de transformação e descarte do lodo." In: von Sperling, M.; Andreoli, C.V.; Fernades, F. (eds) Lodo de esgotos: tratamento e 
disposição final. Belo Horizonte: DESA-UFMG. p.339-423. Princípios do tratamento biológico de águas residuárias, 6.

Nunes, P. N., Além Sobrinho, P. (2002). "Dimensionamento de adensadores por gravidade". In: XXVIII Congresso Interamericano de Ingenieria Sanitaria y Ambiental, Cancum, México.

Maia, M.L (2006). "Uma Contribuição na análise de viabilidade econômica, social e ambiental no uso do lodo de esgoto na agricultura do Distrito Federal". In: Dissertação de mestrado, Universidade Católica de Brasília, 91p

Maya, C.; Ortiz, M.; Jiménez, B. (2010). "Viability of Ascaris and other helminth genera non larval eggs in diferente conditions of temperature, lime $(\mathrm{pH})$ and humidity”. In: Water Science and Technology. 62(11), p.16-24

Melo, W.J., Marques, M.O. (2000). "Potencial do lodo de esgoto como fonte de nutrientes para as plantas". In: Betitiol, W. e Camargo, O.A.(eds), Impacto ambiental do uso agrícola do lodo de esgoto. Jaguariúna, SP. EMPRAPA Meio Ambiente, p.11-24.

Medeiros, E. M. N. de (2006). "Sistema de gestão da qualidade na indústria cerâmica vermelha. Estudo de caso de uma indústria que abastece o mercado de Brasília”. In: Dissertação de mestrado, Faculdade de Tecnologia, Departamento de Engenharia Civil e Ambiental, UnB, 190p.

Metcalf, B.; Eddy, I.N.C. (1991). Wastewater Engineering: Treatment, Disposal and Reuse. $3^{\mathrm{a}}$ ed., 765-926, New York : McGraw-Hill. E.U.A.

Miki, M. K., Além Sobrinho, P., van Haandel, A.C. (2006) "Tratamento da fase sólida em estações de tratamento de esgotos - condicionamento, desaguamento mecanizado e secagem térmica do lodo". In: Andreoli, C. V (ed). Alternativas de Uso de resíduos do Saneamento - Projeto PROSAB, Rio de Janeiro, ABES.

Miyazawa, M., Gimenez, S.M.N., Fernandez, F., Oliveira, E.L., Silva, C.P. (2001). "Aspectos agronômicos; efeito do lodo de esgoto nos teores de metais pesados no solo e na planta", cap. 04. In: Reciclagem de Biossólidos - Transformando Problemas em Soluções, $2^{\text {a }}$ Ed. SANEPAR, FINEP. Curitiba, PR, p.204 -205.

Morales, G.; Agopyan, V. (1992). "Caracterização de agregado leve obtido a partir do lodo de esgoto da cidade de Londrina." In: Boletim Técnico da Escola Politécnica da USPBT/PCC/64, pp. 1-20. Apud Fontes, C. M. A. (2003). "Potencialidades da Cinza de lodo de Estações de Tratamento de Esgotos como material suplementar para a produção de concreto com cimento Portland”. In: Dissertação de Mestrado em 
Engenharia Civil - UFRJ, COPPE, XXp.

Mun S.; Cho, S.T.; Kim, T.S.; Yoon J.(2009). "Inactivation os Ascaris eggs in soil by microwave treatment compared to UV and ozone treatment". In: Chesmosphere. 77, p.285-290.

Nascimento, C., W., A.; Barros, D., A., S.; Melo, E., E., C.; Oliveira, A., B. (2004). "Alterações químicas em solos e crescimento de milho e feijoeiro após aplicação de lodo de esgoto". In: Revista Brasileira de Ciência do Solo, (28), p.385-392.

Oliveira, F.C.; Mattiazzo, M.E.; Marciano, C.R.; Moraes, S.O.(2001). "Lixiviação de nitrato em um Latossolo amarelo distrófico tratado com lodo de esgoto e cultivado com cana-de-açúcar.” Scientia Agricola, 58(1), p.171-180.

Oliveira, R.F.; Gambôa, F.A.R; Santos, F.R.S. (2003). "Conceitos de logística reversa e colaboração aplicados à indústria de especialidade químicas", In: Anais do $X$ SIMPEP - Simpósio de Engenharia de Produção. Bauru/SP: Faculdade de Engenharia. Bauru.

Onaka, T. (2000). "Sewage can make Portland cement: a new technology for ultimate reuse of sewage. In: Water Science \& Tecnology, 41(8), p. 93-98.

Papadimitriou, C.A., Haritou, I., Samaras, P., Zouboulis, A.I. (2008). "Evaluation of leaching na ecotoxicological properties of sewage sludge-fly ash mixtures". In: Environmental Research, 106, 340-348.

Passamani, F.R.F., Keller, R., Gonçalves, R.F. (2002) "Higienização de lodo utilizando caleagem e pasteurização em uma pequena estação de tratamento de esgoto combinando reator UASB e biofiltro aerado submerso". In: Anais do XXVIII Congresso Interamericano de Ingeniería Sanitária y Ambiental, Cancun: México.

Passamani, F.R.F.; Motta, J.S.; Figueiredo, K.F.; Gonçalves, R.F. (2000) "Pasteurização do lodo de um reator UASB na remoção de coliformes fecais e ovos de helmintos”, In: Anais do I Seminário nacional de Microbilogia Aplicada ao Saneamento, Vitória, ES.

Paulino, C.R., Castro, E.A., Soccol, V.T. (2001). “Tratamento anaeróbio de esgoto e sua eficiência na redução da viabilidade de ovos de helmintos” In: Revista da Sociedade Brasileira de Medicina Tropical, 34(5), 421-428.

Pedroza, E.C.L., Moreira, E.A., Cavalcanti, P.F. F., Além Sobrinho, P.; Andreoli, C., van Haandel. (2006) "Aplicação de leitos para secagem de lodo gerado em estações de tratamento de esgotos". In: Andreoli, C. V (ed). Alternativas de Uso de Resíduos do 
Saneamento - Projeto PROSAB. Rio de Janeiro: ABES.

Pedroza, P.J., Beltrão, N.E.M., van Haandel, A.C., Gouveia, J.P.G., Eite, J.C. (2005). "Doses crescentes de biossólidos e seus efeitos na produção de componentes do algodoeiro herbáceo".In: Revista de Biologia e Ciências da Terra, 5(2). Univesidade Estadual da Paraíba.

Pegorini E.S., Andreoli, C. V. (2006). Alternativas de Uso de Resíduos do Saneamento. Rio de Janeiro: ABES.

Pegorini, E.S. (2002). “Avaliação de impactos ambientais do programa de reciclagem agrícola de lodo de esgoto na região metropolitana de Curitiba”. In: Dissertação de mestrado. Curitiba: Universidade Federal do Paraná.

Pires, M.S.G.(2003) “Avaliação da presença de patógenos no lodo líquido estabilizado de ETE (processo aeróbio) quando aplicado ao solo arenoso-siltoso”. Tese doutorado Universidade Estadual de Campinas, Faculdade de Engenharia Civil, Campinas, SP, $162 \mathrm{p}$.

POE/CAESB (2013). Relatório Operacional da Superintendência de Operação, Tratamento de Esgotos. CAESB - companhia de Saneamento Ambiental do Distrito Federal, Brasília, Brasil.

Poggiani, F.; Silva, P.H.M. da; Guedes, M.C. (2006). "Uso do lodo de esgoto em plantações Florestais". In: Andreoli, C. V (coord.). Alternativas de Uso de Resíduos do Saneamento.p.159-183.

Popat, S.C.; Yates, M.V.; Deshusses, M.A. (2010); "Kinetics of inactivation of indicator pathogens during thermophilic anaerobic digestion”. In: Water Research; 44: 59655972.

Ramos, R. A. (2008). “Avaliação da influência da operação de descarte de lodo no desempenho dos reatores UASB em estações de tratamento de esgotos no Distrito Federal.” Dissertação de Mestrado em Tecnologia Ambiental e Recursos Hídricos Departamento de Engenharia Civil e Ambiental, UNB, Brasília, DF, 133p.

Rodrigues, A. S. (2007). "Poluentes e fontes: orgânicos”. In: Química das águas. São Paulo, p.18. (Revisão)

Rulkens, W.H. (2004). "Sustainable sludge management: what are the challenges for the future?” In: Water Science \& Techology.(10)11-19.

Qasim, S.R. "Wastewater treatment plants: planning, design and operation. New York: Holt, Rinehart and Winston”, 1985 (2001) apud von Sperling, M.; Gonçalves, R.F.: 
Lodo de esgotos: características e produção. In: Andreoli, C.V.; von Sperling, M.; Fernandes, F. Lodo de esgotos: tratamento e disposição final. Belo Horizonte: DESA - UFMG; Curitiba: SANEPAR. 484p. (Princípios do tratamento biológico de águas residuárias (6) cap.2, p.17-67

Sánchez-Monedero, M.A., Mondini, C., Nobili, M., Leita, L., Roig, A. (2004). "Land application of biosolids. Soil response to different stabilization degree of treated organic matter". In: Waste Management, 24, 325-332.

Santos, H.F. (2001). "Normatização para o uso agrícola dos biossólidos no exterior e no Brasil. In: Sperling, M.V., Andreoli, C.V., Fernandes, F. (eds) Lodo de esgotos: tratamento e disposição final, Belo Horizonte: SESA-UFMG, p.425-464.

Santos, L. H. M. L. M. (2010) Ecotoxicological aspects related to the presence of pharmaceuticals in the aquatic environment. Journal of Hazardous Materials, 175, (1-3), p. 45-95, ISSN 0304-3894.

Scheer, M. B, Carneiro, C.; Santos, K.G. (2010). "Substratos à base de lodo de esgoto compostado na produção de mudas de Parapiptadenia rigida (Benth.) Brenan”. In: Scientia Forestalis, Piracicaba, 38(88), p. 637-644.

Silva, J. E., Dimas, V. S. R., Sharma, R. D. (2000). "Alternativa agronômica para biossólido: a experiência de Brasília”. In: Bettiol, W. e Camargo, O.A. (ed) Impacto ambiental do uso agrícola do lodo de esgoto, Jaguariúna: EMBRAPA Meio Ambiente, p.143-162.

Silva, S.M.C.P.; Fernandes, F.; Soccol, V.T.; Morita, D.M. (2001). "Principais contaminantes do lodo", cap 03. In: Lodo de Esgotos: Tratamento e Disposição Final - Princípios do Tratamento Biológico de Águas Residuárias, 6. DESA UFMG, SANEPAR. Belo Horizonte, MG, p.69 - 70; 92.

Silva, J. E.; lemainski, J.; pereira, C. E. B. (2007) "Efeito residual e reaplicação de lodo de esgoto em milho no Distrito Federal”. In: XXXI Congresso Brasileiro de Ciência do Solo, gramado, RS, SBCS. CD-ROM.

Silva, R. F. da, (2007). “Compostagem e solarização para higienização de lodo de esgoto e uso no cultivo de cássia amarela (Senna siamea Lam)". In: Tese de Doutorado Universidade Federal de Pernambuco. Programa de Pós-Graduação em Engenharia Civil. Recife, PE

Soccol, V.T., Paulino, R.C., Castro, E. (2000). "Metodologia para análise parasitológica em lodo de esgoto. In: Andreoli, C.V. (ed), Manual de métodos para análises 
microbiológicas e parasitológicas em reciclagem agrícola de lodo de esgoto, Companhia de Saneamento do Paraná, 2a ed., Curitiba: SANEPAR, 27-41.

Soccol, V.T.; Paulino, E.C.; Castro, E.A. (2001) “Agentes patogênicos: Helmintos e Protozoários. In: Andreoli, C.V.; Lara, I.A. de; Fernandes, F. (Eds), Reciclagem de Biossólidos. Curitiba: Sanepar, FINEP, p.156-179.

Soccol, V.T.; Paulino, E.C.; Pereira, J.T.; Castro, E.A.; Costa, A.O.; Henning L; Andreoli, C. (2010) "Organismos patogênicos presentes em lodo de esgoto a ser aplicado no solo e a Resolução n³75 do CONAMA”. In: Coscione A.R.; Nogueira T.A.R.; Pires A.M.M. (eds): Uso agrícola de lodo de esgoto: avaliação após a Resolução $n^{\circ} 375$ do CONAMA. $1^{\text {a }}$ ed. Botucatu: FEPAF, p.83-112.

Souza, C.A; Lemainski, J.; Silva, J.E.;Mazzotti, H.A. (2008). "Sobrevivência de ovos de helmintos na reciclagem agrícola do lodo de esgoto no Distrito Federal”. In: Anais do IX Simpósio Nacional Cerrado - II Simpósio Internacional Savanas Tropicais,

Souza, M. A. S.; Silva, C. A. I.; Alcântara, L. P. de; Borges, E. N. (2006). "Variabilidade Espacial do atributo químico saturação por bases em três regiões do cafeeiro sob diferentes sistemas de manejo em um Latossolo vermelho amarelo distrófico" In:. IV - Encontro Americano de Pós-graduação - Universidade do Vale do Paraíba, p. 1545-1548.

Sperling, M V., Gonçalves, R.F. (2001). "Lodo de esgotos: características e produção. In: Andreoli C. V.; Sperling, M., Fernandes, F. (Ed) Lodo de Esgotos: Tratamento e Disposição Final. Belo Horizonte: Departamento de Engenharia Sanitária e Ambiental - UFMG: Companhia de Saneamento do Paraná.

Sperling, M.; Andreoli, C.V. (200X). "Princípios do tratamento biológico de águas residuárias". In: Andreoli, C.V.; von Sperling, M.; Fernandes, F. (Org) Lodo de esgotos: tratamento e disposição final. Belo Horizonte: DESA - UFMG; Curitiba: SANEPAR, 484p., 6, p.13-16.

Sperling, M. (2002). Lodos Ativados. 2.ed. BeloHorizonte: Departamento de Engenharia Sanitária e Ambiental - UFMG, 480p. (Princípios dotratamento biológico de águas residuárias.

Sperling, M. (2005). "Introdução à qualidade das águas e ao tratamento de esgotos". 3.ed. Belo Horizonte: Departamento de Engenharia Sanitária e Ambiental - UFMG, 243p. (Princípios do tratamento biológico de águas residuárias.

Spinosa, L. (2007). "Status and perspectives of sludge management". In: Conference 
Proceedings - Moving Forward - Wasterwater Biosolids Sustainability - Technical, Managerial and Public Synergy - $4^{\mathrm{a}}$ Canadian Organic Residuals and Biosolids Conference. Moncton, New Brunsic, Canadá, p.24-27.

Skorupa, L. A.; Souza, M. D.; Pires, A. M. M.; Filizola, H. F.; Bettiol, W.; Guini, R. M. A. V. (2006). "Uso de Lodo de Esgoto na Recuperação de Áreas Degradadas”. In: Andreoli, C. V (coord.). Alternativas de Uso de resíduos do Saneamento - Projeto PROSAB. Rio de Janeiro: ABES, p.189-229.

Szavobá E.; Jevis P.; Papajová I. (2010) "Sanitation composting process in different seasons: Ascaris suum as model”. In: Waste Management; 30:426-432.

Tay J.H, Show, K.Y., Hong, S.Y. (2002) "Potential Reuse of Wastewater Sludge for Innovative Aplications in Construction Industry", Bulletin of the College of Engineering,N.T.U., 86,03-112.

Tezotto, T.; Favarin, J.L.; Azevedo, R.A.;Alleoni, L.R.F. (2012). “Coffee is highly tolerant to cadmium, nickel and zinc: Plant and soil nutritional status, metal distributin and bean yeld". In: Field Crops Research. 125, p.25-34.

Trigueiro, R.M., Gerrini, I. A. (2003). "Uso de biossólido como substrato para a produção de mudas de eucalipto". In: Scientia Forestalis, 64, p.150-162.

Tsutiya, M.T. (2001a). “Características de biossólidos gerados em estações de tratamento de esgotos". In: Tsutiya, M.T., Comparini, J.B., Alem Sobrinho, P., Hespanhol, I.,Carvalho, P.C.T., Melfi, A.J., Melo, W.J. e Marques, M.O. (Eds). Biossólidos na Agricultura. ABES, São Paulo, SP, p. 89-129.

Tsutiya, M.T (2001b). "Alternativas de disposição final de biossólido”. In: Tsutiya, M.T.; Comparini, J.B.; Sobrinho, P.A.; Hespanhol, I.; Carvalho, P.C.T.; Melfi, A.J.; Melo, W.J. \& Marques, M.O., eds. Biossólidos na agricultura. São Paulo, SABESP, Escola Politécnica - USP, ESALQ, UNESP, p.133-180.

Tsutiya, MT. (1999). "Metais pesados: o principal fator limitante para o uso agrícola de biossólidos das estações de tratamento de esgotos. In.: Anais do Congresso Brasileiro de Engenharia Sanitária e Ambiental, Rio de Janeiro, RJ: ABES, 753761.

Turovskiy, I.S. e Mathai, P.K. (2006). Wastewater Sludge Processing. Jonh Wiley \& Sons, Inc., Hoboken, New Jersey, 354 p.

U.S. Environmental Protection Agency (1992). "Control of pathogens and vector attraction". In: Sew age Sludge: Under 40 CFR Part 503. EPA 625/R-92/013. 
Washington, D.C.

U.S. Environmental Protection Agency (1997). "Land application of biossolids: process design manual”. E.U.A., Cincinnatti.

U.S. Environmental Protection Agency (2000). "Poland Biosolids Smelter Waste Reclamation Project" EPA 832-R-00-009, Office of Water, Washington, D.C., Region 3, Philadelphia, PA.

U.S. Environmental Protection Agengy (1999). “Biosolids generation, use, and disposal in The United States". EPA 530-R-99-009.

Wang, C.; Li; X.C.; Ma, H., Qian, J., Zhai, J. (2006). "Distribution of extractable fractions of heavy metals in sludge during the wastewater treatment process". In: Journal of Hazardous Materials A137, 1277-1283.

WHO (2008) United Nations Children's fund joint monitoring programme for water supply and sanitation (JMP). ed. New York: UNICEF. p.

Zábranská, J.; Doháyos, M.; Jenicek, P.; Kutil, J (2000). “Thermophilic process and enhacement of excess activated sludge degradability- two ways of intensidication of sludge treatment in the Prague Central Wastewater Treatment Plant”. In:Water Science \& Technology, 49, (9) 265-272. 